\title{
POPULATION, PROVIDENCE AND EMPIRE
}

THE CHURCHES AND EMIGRATION FROM NINETEENTH-CENTURY IRELAND

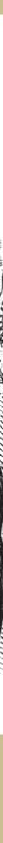




\section{Population, providence and empire}

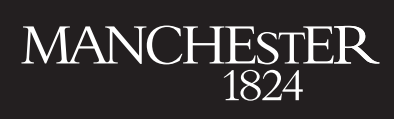

Manchester University Press 



\section{Population, providence and empire}

The churches and emigration from nineteenth-century Ireland

SARAH RODDY

Manchester University Press 
Copyright (C) Sarah Roddy 2014

The right of Sarah Roddy to be identifi $d$ as the author of this work has been asserted by her in accordance with the Copyright, Designs and Patents Act 1988.

Published by Manchester University Press

Altrincham Street, Manchester M1 7JA, UK

www.manchesteruniversitypress.co.uk

This electronic version has been made freely available under a Creative Commons (CCBY-NC-ND) licence, thanks to the support of The University of Manchester, which permits non-commercial use, distribution and reproduction provided the author(s) and Manchester University Press are fully cited and no modifications or adaptations are made. Details of the licence can be viewed at https://creativecommons.org/licenses/by-nc-nd/4.0/

British Library Cataloguing-in-Publication Data

A catalogue record for this book is available from the British Library

Library of Congress Cataloging-in-Publication Data applied for

ISBN 9780719090196 hardback

First published 2014

The publisher has no responsibility for the persistence or accuracy of URLs for any external or third-party internet websites referred to in this book, and does not guarantee that any content on such websites is, or will remain, accurate or appropriate.

Typeset in Minion with Rotis Sans display by Koinonia, Manchester 
For Seamus Roddy (1947-2011) 



\section{Contents}

Preface $\quad$ ix

Abbreviations xii

Introduction 1

Part I

1 Talk of population: the clergy and emigration in principle 23

2 The emigrant's friend?: the clergy and emigration in practice 62

3 'Scattered abroad, as sheep having no shepherd': the pastoral responses of the Irish churches to emigration

\section{Part II}

4 The battlefield against popery: emigration and sectarian rivalry

5 The spiritual empire at home: emigration and the spread of Irish religious influence

Conclusion

Select bibliography

Index 



\section{Preface}

We hardly need proof that historians are influenced by the times in which they write, but this book might provide some. I began my research in 2006, as the Republic's Tiger economy was as its roaring height, and as the end of the long Northern Irish Peace Process was in sight, at which time 'emigration' did not seem quite the dirty word it may have been to previous generations. Being from one jurisdiction, and living and studying in the other, I was aware that 'the Irish diaspora' - a term prematurely introduced to my childhood consciousness by President Mary Robinson in the mid-1990s - had played key parts in these two apparently welcome developments. Moreover, at the time, my personal experience of migration amounted to aunts and uncles who seemed happily settled abroad and who managed to make regular return visits (in one case a permanent one), and friends and peers who, at that point, had very definitely left Ireland for adventure and opportunity with no sense of being surplus to the requirements of the economy at home. Indeed, the papers I gave early in my research career tended to note that, for the first time in several centuries, Ireland was a country of relatively happy mass immigration, rather than of miserable mass emigration.

Thus, the twenty-first-century Irish migration I knew and the nineteenth-century Irish emigration I was researching seemed initially to be very different beasts: one a voluntary movement of the skilled and professional in search of 'a change of scene', the other a needful and largely resented migration of the poor and unskilled. Revising the text more recently, as one of many in a vast new wave of Irish 'exiles' - most of whom, educated, skilled, or not, were very much surplus to post-Tiger requirements - I came to see things slightly differently. Though the experiences of most of today's Irish migrants are still a 
world away from those of the nineteenth century, it was instructive to monitor, from afar, the reactions to this new outflux in Ireland itself. The old tropes seemed to be dusted off at the merest hint of increased emigration: newspapers wrote lamenting editorials, priests said masses - these days even online - for the departed, and politicians lamely blamed external forces. On the surface, the way Ireland publicly discusses and rationalises its intermittent need to export large sections of its population hasn't changed very much in two centuries. Future historians will have to determine the extent to which these public responses were matched by private action, and how Ireland itself was again changed - as it inevitably will be - by this current wave of emigration.

This book came to fruition with a great deal of help from other people. I am first and foremost grateful to the staff and students of the School of History and Anthropology at Queen's University Belfast, where the book started life as a doctoral thesis. I particularly thank Professor Peter Gray who provided supervision that was invariably thorough, stimulating, kind and encouraging. At various points, Professors Liam Kennedy and Sean Connolly, and Drs Marie Coleman and Andrew Holmes read sections and offered useful criticism and suggestions, for which I thank them. I am also indebted to Professor David Hayton for securing the University Studentship that made the research possible, and to many of my then fellow postgraduate students, particularly Aidan Enright, Pierre Ranger and Jonathan Wright, for enlightening discussion and welcome distraction.

I wish also to express my gratitude to Dr Enda Delaney, who examined the original thesis and has been an encouraging influence ever since. Professors Kerby Miller and David Fitzpatrick offered generous encouragement and much appreciated advice at early stages, and I am grateful to Oliver Rafferty, Liam Kennedy, Ciaran O’Neill and Joseph Hardwick for allowing me to read drafts of their unpublished work.

The staff at a number of libraries and archives across Ireland courteously facilitated my research. In Belfast, I thank the following: Diarmuid Kennedy and the staff of Special Collections and of the McClay library at Queen's; Stephen Gregory and staff at the Gamble Library, Union Theological College; Jennifer Dickson, Valerie Adams and Godfrey Brown of the Presbyterian Historical Society; the respective staffs of the Public Record Office of Northern Ireland, 
Belfast Central Library, Belfast Newspaper Library and the Linenhall Library. Elsewhere in Northern Ireland I received help from staff at the Cardinal O'Fiaich Library in Armagh and Mary McVeigh of the Ulster and Local Studies Library in the same city; Patrick Fitzgerald at the Centre for Migration Studies in Omagh and Joe McLaughlin at Magee College, Derry.

In Dublin, I was grateful for the efficiency of the staffs of the National Library of Ireland, the Royal Irish Academy and Trinity College Library. I also thank Noelle Dowling of the Dublin Diocesan Archives, Greg Harkin of All Hallows College, Susan Hood of the Representative Church Body Library and Andrew O'Loughlin at St Paul of the Cross Retreat, Mount Argus.

The British Library proved the repository of last resort for a number of obscure pamphlets consulted, but I must also acknowledge an enormous debt to the digitisation projects of a number of North American and British libraries, which made accessible several important works that could not otherwise have been read. In the same vein, the briefly available digitised records of the Pontifical Irish College in Rome were - perhaps not literally - a godsend and I thank the former archivists, Vera Orschel and Martin Fagan, for help in navigating the project.

In Manchester, my colleagues in the School of Arts, Languages and Cultures, particularly Julie-Marie Strange and Bertrand Taithe, have helped in many ways, primarily in making me (I hope) a better historian. The staff of Manchester University Press have been a pleasure to deal with, and I thank their two anonymous readers for saving me from several errors of fact, interpretation and style.

I finally thank my family in Westmeath, Galway and Belfast, especially my mother Eileen, for their love and great support; Colm, who knows what he did; and friends in Ireland and the UK, some of whom might still be under the impression that the following book is about potatoes. (Once again, it isn't.)

This book is dedicated to the memory of my father, a musician who spent many years before I was born playing in dancehalls all over Ireland and among the diaspora in England and America. But that, I hope, is another story. 


\section{Abbreviations}

A.D.A. Armagh Diocesan Archives

A.H.C. All Hallows College

A.P.F. Association for the Propagation of the Faith

B.N.L. Belfast News Letter

C.D.A. Cashel Diocesan Archives

D.D.A. Dublin Diocesan Archives

F.J. $\quad$ Freeman's Journal

I.C.R.A. Irish College Rome Archives

I.E.D. Irish Emigration Database

I.E.R. Irish Ecclesiastical Record

I.E.S.H. Irish Economic and Social History

I.H.S. Irish Historical Studies

M.G.A. Minutes of the General Assembly of the Presbyterian

Church in Ireland

M.H. Missionary Herald

N.A.C.A.I. North American Colonial Association of Ireland

N.L.I. National Library of Ireland

P.R.O.N.I. Public Record Office of Northern Ireland

S.P.G. Society for the Propagation of the Gospel in Foreign Parts

U.N.D.A. University of Notre Dame Archives

W.T. Weekly Telegraph 


\section{Introduction}

Between seven and eight million men and women left Ireland over the course of the nineteenth century. ${ }^{1}$ For a country whose population has never been more than eight and a half million, that is a mind-boggling statistic, and one that might easily obscure individual emigrant lives. Historians have therefore tended to tackle Irish emigration in two disparate but complementary ways: some from the top down, with sophisticated statistical analysis, others from the bottom up, with recourse to the authentic voices of emigrants themselves. They have succeeded in breaking down that intimidating number by establishing broad patterns of who departed and when, where from and where to, and the gender and class balances amongst them. They have documented and contextualised the experiences of individual migrants as gleaned from thousands of surviving letters and memoirs. ${ }^{2}$ Consequently we know a great deal about 'the Irish diaspora' and its often profound impact on the countries to which it spread.

Yet the great blind spot of migration history is the effect a significant national diaspora has on the sending society. ${ }^{3}$ After all, the country most affected by nineteenth-century Irish emigration was not the United States, where the largest proportion of emigrants went, nor Australia, which had a higher ratio of immigrants from Ireland among its population than from any other country, but Ireland itself, from where all of them ultimately came. This study proposes to improve our understanding of the phenomenon of Irish emigration by concentrating on Ireland rather than its diaspora, and within those parameters to look at a significant and hitherto overlooked aspect of the two-way relationship between the sending society and the outflow. Specifically, it seeks to ascertain and compare how the Irish 
Catholic, Presbyterian and Anglican churches responded to sustained emigration from their congregations during the nineteenth century, and in turn how they were affected by it, and, just as importantly, how they believed themselves to be affected by it. The book therefore knits together two of the most significant themes in the social and cultural history of modern Ireland - mass emigration and religious change and aims to provide fresh insight into both.

There is a reasonable popular assumption that Irish emigration on a significant scale began only in the nineteenth century. Many regard the Great Famine as Ireland's mass migration 'year zero', while others might be aware that the economic slump after the end of the Napoleonic wars in 1815 prompted consistent outward movement. Although there is some truth to both points, emigration from Ireland before 1815 was by no means negligible, and each of the three major churches in Ireland consequently had at least some involvement in it. As Professor Kerby Miller has noted, migration during this period did not proportionally reflect the religious composition of the Irish population. ${ }^{4}$ Absolute figures for the long eighteenth century are unreliable and in much dispute. ${ }^{5}$ However, it is widely agreed that the Presbyterian Church's members, a minority within the wider population, formed by some distance the greatest proportion of migrants in the century and a half up to 1815 , perhaps as much as three-fifths of the total. Thus, the Presbyterian Church has unsurprisingly left the largest trace of its engagement with the phenomenon during this period. The growing secondary literature on the 'Ulster Scots', who became 'Scotch Irish' when translated across the Atlantic, recognises the extent to which religious ministers in Ireland had a conflicted view of the exodus, occasionally encouraging it from the pulpit as the right course for individuals whom they regarded as religiously persecuted, and at other times expressing dismay at the economic consequences for the home church. ${ }^{6}$ Their Church of Ireland counterparts, whose parishioners migrated in much smaller numbers, forming perhaps a fifth of the total, viewed emigration in more positive terms, as a necessary safety valve for the poor or adventurous among them. Indeed, their strongest feeling on the matter may have been a selfinterested disdain for the declared religious motives of the Presbyterians for emigrating - which included objections to paying the Church of Ireland tithe - even if later Anglican historians tended to look back on this exodus as a loss to 'the Protestant interest.' ${ }^{7}$ Attitudes 
to emigration within the Catholic Church, to which about another fifth to a quarter of eighteenth-century migrants nominally belonged, are more difficult to discern. If Miller's assertion that the majority of these early Catholic migrants were 'rootless' holds true, however, then it seems unlikely that their removal caused their clergy a great deal of practical trouble or mental anguish. ${ }^{8}$

Outward migration in the nineteenth century was a different matter. By 1815 , Ireland's population had expanded to almost seven million, more than double what it had been only a century before, and emigration had reached similarly unprecedented levels. Three distinct phases of nineteenth-century Irish emigration can be discerned. Firstly, it has been estimated that in the thirty years prior to the potato blight, even as the home population continued to increase, as many as one and a half million people emigrated, mainly to North America and Great Britain. ${ }^{9}$ Then, between 1846 and 1855, another two and half million left in a torrent of crisis migration unleashed by the Great Famine. Finally, there came a further four million, more considered, departures in the six decades leading up to the Great War, at which point shipping, and therefore emigration, was curtailed. ${ }^{10}$ Significant gaps in demographic data mean the religious breakdown of this enormous outflow is impossible to state with confidence. Statistics from the primary destination countries - the United States, Britain, British North America (Canada), the Australian colonies, and New Zealand - are only of limited help, since the religious profession of immigrants tended to go unrecorded by officials. ${ }^{11}$ Moreover, before 1861, Ireland's decennial censuses, the accuracy of which were often questionable, recorded religious affiliation only once, in the 1830s. Those figures, released in 1834, suggest the Catholic, Anglican and Presbyterian proportions of the population were approximately $80.9 \%, 10.7 \%$, and $8.1 \%$ respectively. In 1861 , the ratio had changed to $77.7 \%, 12 \%$, and $9 \%$, and by 1901 the figures were $74.2 \%, 13 \%$ and $9.9 \%$.

These statistics suggest three pertinent points. Firstly, while they clearly indicate an overwhelmingly Catholic exodus that steadily reduced the Catholic ratio of the population, it must be acknowledged, as Professor Donald Akenson has robustly contended, that throughout the century Protestants represented at least as large a proportion [of the outflow] as they were of the home population. ${ }^{12}$ This assertion is borne out by the quantities behind the above percentages, which show significant falls in the absolute number, as distinct from the relative proportions of each church's adherents. ${ }^{13}$ Secondly, 
the census religious figures, or rather their intermittent nature, denote that in the mid-century period of the most intense outward movement, the precise religious make up of the static population, let alone of the mobile Irish born, was in doubt, leaving room for heated sectarian disputes over mass emigration's effect on Irish religious demography, as we shall see. Thirdly, these figures show that the three churches considered here account for between $97 \%$ and $99 \%$ of the island's population over the course of the nineteenth century.

This last point goes some way to explaining why the other dissenting or non-conformist (i.e. non-Anglican, established) Protestant churches in Ireland do not form part of the analysis that follows. According to that year's census, by 1901 there were just 125,000 Irish residents who attended churches outside the three major denominations (up from 21,808 in 1834, and 77,000 in 1861). ${ }^{14}$ Baptists, Quakers, Methodists and the rest were a tiny, if fluctuating, share of the Irish population throughout the nineteenth century, and their clergy were consequently very few in number. ${ }^{15}$ To be sure, these people left Ireland in large proportions relative to their absolute numbers, and had done so from the late seventeenth century onward, contributing disproportionately to the early spread of those faiths across the globe, but in doing so they were undermined at home. Irish Baptists, who arrived with Cromwell and began returning to England or leaving for North America (attracted by better land opportunities) within a matter of decades, saw their share of the population reduced to only about 500 persons by 1800 . Various waves of revivalism swelled their numbers tenfold during the ensuing century, but emigration remained a steady drain on Baptist congregations during that time, particularly outside of Ulster. ${ }^{16}$ The emigration of Irish Quakers had a similar effect. They were a key source of migrants to the Pennsylvania colony from its foundation in 1682, and were therefore part of an active transatlantic religious network well into the nineteenth century. However, by 1901 there were fewer than 3,000 of them left behind in Ireland. ${ }^{17}$ Notwithstanding the high levels of emigration, legitimate questions as to the extent to which such tiny religious bodies might provide sufficient depth of evidence for a multi-faceted comparison with the larger churches in Ireland have prompted their exclusion from this study.

Methodists, as the largest of the minor denominations, were a trickier proposition. By 1901 there were 62,000 Methodists in Ireland and they had contributed not insignificantly towards Irish emigration figures. Their own Church conference minutes record some 38,500 
Methodists departing Ireland, mainly for North America, between 1830 and $1900 .{ }^{18}$ By 1870, there were said to be more Irish Methodists in the United States than in Ireland. ${ }^{19}$ For that reason, some of the same practices and attitudes relating to emigration can be discerned in Methodist clergy as in those of the three major churches. While the Methodist Church, again, does not form a full comparison with the Presbyterian, Anglican and Catholic churches in this book, peppered throughout the footnotes the reader can find references from secondary and occasionally primary sources which demonstrate some key points of crossover. Also confined to the margins of the analysis are fraternal associations, including the pan-Protestant Orange Order founded in Ulster in 1796, the Catholic Ancient Order of Hibernians, begun in the United States in 1836 and the Limerick founded Catholic Young Men's Society, founded in 1849. Belonging to these organisations may have been predicated on religious affiliation, as historians have shown, and while their reach may have extended across the diaspora and homeland, ${ }^{20}$ and their structures may have been employed in the transfer of migrants, their membership, both lay and clerical, is also largely accounted for in that of the three major churches. Thus, confining the book to three churches and to the nineteenth century allows a deeper comparative approach and reflects the fact that the focus is on Ireland, rather than the destination countries

This book's focus on the sending society has some precedents as far as migration history goes. A number of historians of nineteenthcentury Irish emigration have taken care to establish the 'push factors' in Irish society that may have influenced departures, as well as some of the ways in which the mass exodus subsequently changed Ireland. However, the focus, as elsewhere, has tended to be on economics. ${ }^{21}$ Most agree that a fundamental lack of economic opportunity at home was the key determinant of outward migration, and that the loss of population had discernible consequences for the development, or more often, lack of development of the Irish economy. ${ }^{22}$ Fewer studies have assessed how other elements of Irish culture and society affected or were affected by the mass population movement. Arnold Schrier's pioneering Ireland and the American Emigration was a worthy attempt to do just that, but it was, as the author himself later noted, a preliminary treatment, leaving much work still to be done. ${ }^{23} \mathrm{~A}$ few inroads have since been made into this territory. There have been useful demographic studies of how emigration shaped Irish social 
and family structure, and the unique emigration patterns of Irish women (and what has been termed the defeminisation of the Irish countryside') have begun to be explored. ${ }^{24}$

However, historians of nineteenth-century migration have yet to come to grips with the variety of ways in which the churches in Ireland engaged with the issue. This oversight is especially puzzling when one considers the central significance of religion within Irish history more generally, and the extent to which historians of the diaspora have examined the religious dimension of migrant life in their various destinations; for instance the churches' roles in helping immigrants to settle and to prosper, if not always to assimilate, has been a major theme in Irish diaspora studies. ${ }^{25}$ The relevant literature that does exist tends to be of a limited nature, often following Schrier's lead in identifying a particular strain of post-famine anti-emigration rhetoric among Catholic priests, primarily from provincial newspaper sources. ${ }^{26}$ Even then, such accounts fail to explore the contradiction that lay at the heart of this apparently clear cut condemnation, namely that significant numbers of Catholic clergy were actively involved in the emigration process. This involvement itself has been subject to fitful inquiry. David Fitzpatrick has discussed some of the practical facilitation priests offered to would-be emigrants, while Gerard Moran has pointed toward clergy-led schemes of colonisation, as well as clerical reaction to landlord-financed migration, in his synthesis of material on assisted emigration. ${ }^{27}$ Perhaps most relevant is Oliver MacDonagh's succinct examination of aspects of the practical and rhetorical responses of the Catholic clergy during the Famine, although in limiting his study to a period of crisis, MacDonagh arguably captured an unrepresentative, or at least incomplete, snapshot. ${ }^{28}$

Kerby Miller's corpus of work, particularly Emigrants and Exiles, offered a more nuanced and convincing take on Catholic clerical conceptions of migration. Miller argues that Catholic priests, alongside 'strong farmers' and nationalist politicians, contributed to a traditionalist 'explanation' of emigration as 'exile' which suited each of their particular bourgeois ends, and which manifested itself in the mentality of Irish migrants, as evidenced in surviving correspondence and emigrant literature and song. ${ }^{29}$ Plausible efforts have been made to question the extent to which this culture of 'exile' really does come through in emigrant letters, ${ }^{30}$ though they do not invalidate the idea that what Miller calls 'Catholic spokesmen' may have attempted to paint emigration in those terms. In the present context, however, 
there are a number of potential problems with Miller's approach, not least of which is his sometimes misleading conflation of priests and Nationalist politicians under the one 'Catholic spokesmen' label. Of further concern is the impression that, in one Catholic historian's critique, 'a vast amount of material is being poured into a mould', the end product of which is the 'exile' motif. As another astute commentator in Irish migration studies has noted, 'if 'exile' is a discourse, then it is only one of a number of possible discourses.. ${ }^{31}$ At least as important, arguably, were the clergy's more overtly religious interpretations of mass emigration as the work of Divine Providence.

Two further lacunae stand out from Emigrants and Exiles but are by no means unique to Miller. The first is the absence of any adequate understanding of what Fitzpatrick has rightly identified as the church's primary purpose in relation to the outflow; 'to exhort and minister to the streams of emigrants. ${ }^{32}$ While many historians have hypothesised that a concern for the religious welfare of the departed may have coloured clerical condemnation of the exodus, there has been little substantiating analysis of the pastoral response of the Irish Catholic Church to the mass out-movement of their congregations. ${ }^{33}$ Examination of what the Freeman's Journal termed 'priests for the emigrants' has instead been the almost exclusive preserve of ecclesiastical historians, often moonlighting clergy, who have arguably treated the subject of the pastoral response of the Catholic Church with excessive empathy. ${ }^{34}$ In addition, while the church's concern for the temporal and most especially the moral welfare of emigrants has been better served, particularly in the realm of women's history, it nonetheless requires fresh contextualisation. ${ }^{35}$ The final omission in Emigrants and Exiles - although it is one that Miller has begun to address in other contexts - is the failure to consider the corresponding rhetorical, practical and pastoral responses to emigration on the part of the Irish Protestant churches. ${ }^{36}$ This is matched by a more general neglect of nineteenth-century, and especially post Famine, Irish Protestant emigration, which, as we have seen, can be both blamed on and discredited by the religious statistics. ${ }^{37}$ The nineteenth-century exodus was overwhelmingly Catholic, but the logic of dealing also with the two main Protestant communions, representing over a fifth of the population, is inescapable: any issues relating to emigration which confronted the Catholic Church would surely have been felt just as acutely by the two main Protestant churches, lending an illuminating comparative perspective, while the consequences of mass 
emigration for the increasingly fractious relationship between Protestant and Catholic in Ireland are likely to have promoted considerable comment.

If historians of Irish emigration therefore have an incomplete understanding of the Irish churches' engagement with the matter, what of religious historians' grasp on migration? The most prolific and influential historian of nineteenth-century Irish Catholicism, Emmet Larkin, has recognised the significance of emigration to the church in two discrete, but not wholly unconnected ways. In his three major American Historical Review essays, gathered together in The historical dimensions of Irish Catholicism, emigration is posited as a key enabling factor for what he termed the 'devotional revolution', a phrase that has come to serve as shorthand for the transformation of the post-Famine Catholic Church into one of near-universal religious practice and 'Ultramontane' or Rome-centred conformity. As well as improving the priest-to-people ratio dramatically, Larkin argued, Famine deaths and continued mass emigration left behind the relatively less poor and already more devout sections of society, which created ideal conditions in which to impose even greater Ultramontane orthodoxy. ${ }^{38}$ Meanwhile, in his multi-volume 'mosaic' history of the nineteenth-century church - which is largely treated as an epistolary conversation between bishops - Larkin noted the high degree of concern in the early 1860s over the renewed exodus, and echoed Edward Norman in the view that such concern prompted a deeper episcopal involvement in temporal matters. ${ }^{39}$ Desmond Bowen slightly demurred from that line in the case of Paul Cullen, Archbishop of Dublin and reputed architect of the devotional revolution, suggesting that Cullen cared about emigration only insofar as he could use it to embarrass the government. ${ }^{40}$ This at least presents one possible resolution of the seeming contradiction between Larkin's two conclusions - that the church was fearful of emigration even as it was apparently strengthened by it - but more scrutiny of that point is certainly required.

Historians of nineteenth-century Irish Protestantism, fewer as they are, have come to less solid conclusions about emigration. David Hempton and Myrtle Hill are among those who have emphasised the importance of transatlantic links - nourished by successive waves of emigration - to the development of evangelicalism in Ireland, while Alan Acheson's survey history of the Church of Ireland notes the increasing sense of gloom in the post-disestablish- 
ment church, particularly outside Ulster, as continued emigration left many parishes with only scores of parishioners where there had once been hundreds. ${ }^{41}$ Meanwhile, the significance of emigration for inter-denominational relations has only been hinted at. Bowen suggests that evangelical attempts to foster a 'Second Reformation' in the middle decades of the century may have been partially thwarted by emigration, while also endorsing Larkin's view that, in the longer term, the Catholic Church benefited from the exodus of many of its own adherents. ${ }^{42}$ These assertions, likewise, need to be more rigorously examined.

The work which follows, then, straddles two of the most significant themes in modern Irish history: emigration and religion. This combination means that the book can also be located within two further, emerging bodies of work. The first and slightly older of these might be summarised as 'religion and empire' and concerns the nineteenthcentury diffusion of European religious denominations across the globe, and in particular how the 'home' churches helped with, were affected by, and felt about the process. ${ }^{43}$ By engaging with this scholarship, much of it naturally coming from historians of Britain and its empire, a second set of familiar questions about the ambiguous relationship between Ireland and that empire also necessarily arise. ${ }^{44}$ Most aspects of this relationship have still to be addressed in substantive terms, although scholars are increasingly engaged in doing so, many employing innovative biographical and network analysis approaches. ${ }^{45}$ Here, in exploring different, providential iterations of the Irish 'spiritual empire' as it related to mass emigration and as it was understood by Irish clergy, it is hoped to make a contribution to both of these ongoing discussions.

There are, therefore, a number of key questions to be addressed, and the following five chapters do so thematically. In essence, two interrelated sets of tensions, one primarily concerning emigrants themselves, the other the status of the churches, will be explored. Firstly, clergy in each church, who very often had an important social as well as a spiritual function to carry out in their communities, faced a conflict when it came to a communicant's proposed departure to pastures new. While they may have recognised migration as being in an individual's best economic interest, they could equally regard it as hazardous to their moral and religious wellbeing. Secondly, with regard to their own institutions, clergymen may have found themselves torn between wanting to keep their own congregations intact and their home church 
strong - particularly in relation to the other Irish denominations and wanting to see their particular brand of Christianity expanded abroad by means of emigration. This double dichotomy therefore dictates the structure of the book. Part I, comprising the first three chapters, will address the churches' responses to emigration, both in theory and in practice. Part II, comprising the final two chapters, will assess how emigration impacted on the churches - and the churches' self-conceptions - both in relation to their status in Ireland, and in terms of their ability to spread their influence abroad.

Chapter One deals with the theoretical positions of the clergy of each denomination in relation to emigration and how they changed over the course of the century, as the character of emigration itself altered. Although Oliver MacDonagh has noted the danger of glibly categorising clergymen into 'pro-' or 'anti-emigration' camps, and stated that 'the Catholic Church in Ireland never, as a church, defined for itself an attitude towards emigration' - an assertion equally applicable to the Protestant churches - an attempt is made to discern the broadest swathes of opinion within each communion. ${ }^{46}$ This forms a necessary basis for the wider themes of the book. As the chapter shows, the economic utility of emigration was hotly debated by clergymen, and their stated views on the matter must be understood in order to place their actions properly into context. The chapter uses evidence from contemporary pamphlets, newspapers and periodicals - particularly a vastly underused corpus of religious periodicals - while also having recourse to parliamentary papers, and, in particular, the content analysis of extensive clerical testimony before the 1830s Poor inquiry.

Chapter Two explores the extent of practical clerical involvement in the temporal aspects of emigration. This includes attempts to prevent or limit it, a variety of facilitation services informally offered by parish clergymen, church-backed moves to safeguard emigrant welfare, clerical advice-giving and clerically planned schemes of migration. These are examined with due regard to the patterns of opinion set out in the previous chapter and with the intention of assessing the extent to which clergymen were able to impose their views on the emigration process. The chapter relies for evidence on careful use of literary sources, the accounts of visitors to and travellers in Ireland, clerically authored pamphlets, parliamentary reports and manuscript material from religious archives.

Chapter Three is an extensive, comparative survey of each of the three churches' practical religious involvement in the lives of emigrants, and 
in particular, the systematic provision of clergy by the home churches to emigrant communities. It examines the motivations for such provision, explores the structures put in place to achieve it, and assesses their efficacy. This follows on from some of the concerns over moral and spiritual decay among emigrants touched upon in the previous chapter, exploring how they were addressed, while also providing a basis for understanding a number of issues in subsequent chapters. A wide range of sources employed include religious records, particularly the incredibly rich collections of the Irish College in Rome, emigrants' letters, contemporary pamphlets, missionary periodicals and the chronicles of mission societies themselves.

Chapter Four begins the examination of the impact of emigration on the churches by exploring the consequences and potential consequences of mass population loss for each communion. Tied in with increasing inter-denominational animosity, this primarily postFamine discourse was a heated one, which featured ever-evolving providential interpretations of the exodus and its supposed longterm repercussions. The chapter asks how clergy believed continued emigration would help or hinder their own and the other churches' respective positions, both in Ireland and the wider world. In doing so, it draws on an extensive body of controversial mission literature, religious periodicals, pamphlets, newspapers and archival material.

Chapter Five continues the theme of specifically religious interpretations of the outflow by addressing a commonly referenced but only rarely scrutinised belief in emigration as a divinely dictated mission to spread Christianity across the globe, and consequent conceptions of an Irish 'spiritual empire'. Primarily a Catholic phenomenon, the chapter will assess its extent and nature and determine whether it was the compensatory invention of spokesmen unable to prevent emigration, the cold theodicy of those who cared little for the fate of emigrants themselves, a development with real and tangible consequences for the Irish church or a complicated mixture of all three. It will also ask whether an equivalent and specifically Irish Protestant narrative in relation to lay emigration can be located. The chapter utilises newspapers and periodicals, contemporary books and pamphlets, clerical memoirs and biographies and archival material.

A few explanatory notes on the book may finally be in order. Although the sub-title refers to 'the churches', it will be evident that the focus is primarily on the actions and opinions of male religious personnel, and that, at times, the Catholic Church receives consider- 
ably more attention than the Presbyterian Church and the Church of Ireland. There are sound reasons for this. The authorship of the bulk of the source material, much of it printed and published copy, was unsurprisingly male. Nuns, the remarkable exception of Sister Mary Frances Cusack, the 'Nun of Kenmare' aside, seem to have gone about things in a much quieter fashion. The fact of an overwhelmingly Catholic exodus, moreover, simply means that Catholics often had more to say on the matter than their Protestant contemporaries. Finally, while the chronological parameters of the project are left deliberately fuzzy in the title, it must be noted that, broadly, the study begins with Napoleon's exile in 1815, when Irish men and women could again choose a similar fate. It ends in the new century, with 1902, the year of a definitive statement by the Catholic bishops on emigration and of a number of retrospectives on the previouscentury's migration. These dates also allow a fresh analysis of the bold assertion of the first serious historian of Irish migration, William Adams, that 'in 1815 Irish clergy of all denominations united in opposing emigration. ${ }^{37}$ What follows is an overdue qualification of that suspiciously sweeping statement. It is also an important contribution to Irish migration and religious history in its own right, which confirms the cultural importance of population change in modern Ireland, highlights the wide extent to which these changes were interpreted as providential and shows that, even if clerical denunciations of emigration were largely ineffectual, mass emigration had a significant part to play in both the internal tensions and the external ambitions of the Irish churches.

\section{Notes}

1 Figures adapted from David Fitzpatrick, Irish Emigration 1801-1921 (Dundalk, 1984).

2 For statistical analysis see Fitzpatrick, Irish Emigration, passim; David Fitzpatrick, 'Irish emigration in the later nineteenth century' in Irish Historical Studies, xxii:86 (Sept. 1980), 126-43; D. H. Akenson, The Irish Diaspora: A Primer (Belfast, 1993); S. H. Cousens, 'The regional variation in emigration from Ireland between 1821 and 1841' in Transactions of the Institute of British Geographers, 37 (Dec. 1965), 15-30; J. H. Johnson, 'The distribution of Irish emigration in the decade before the great famine' in Irish Geography, xxi (1990), 78-87; J. H. Johnson, 'The context of migration: the example of Ireland in the nineteenth century' in Transactions of the Institute of British Geographers, xv:3 (1990), 575-600; 
Cormac Ó Gráda, 'A note on nineteenth-century Irish emigration statistics' in Population Studies, xxix:1 (Mar. 1975), 143-9. For use of emigrants' correspondence see Kerby A. Miller, Emigrants and Exiles: Ireland and the Irish Exodus to North America (Oxford, 1985); David Fitzpatrick, Oceans of Consolation: Personal Accounts of Irish Migration to Australia (Cork, 1995); Arnold Schrier, Ireland and the American Emigration, 1850-1900 (Minnesota, 1958); Kerby A. Miller, Arnold Schrier, Bruce Bolling and David N. Doyle, Irish Immigrants in the Land of Canaan: Letters and Memoirs from Colonial and Revolutionary America, 1675-1815 (Oxford, 2003); Patrick O'Farrell, Letters from Irish Australia, 1825-1929 (Belfast, 1984); Ruth-Ann M. Harris, "Come all you courageously": Irish women in America write home' in Éire-Ireland, xxxvi:1 (Summer 2001), 166-84; E. R. R. Green, 'Ulster emigrants' letters' in E. R. R. Green (ed.), Essays in Scotch-Irish History (London, 1969), pp. 87-103; David Fitzpatrick, “That beloved country, that nothing else resembles": connotations of Irishness in Irish-Australasian letters, 1841-1915' in I.H.S., xxvii:108 (Nov. 1991), 324-51; Angela McCarthy, Personal Narratives of Irish and Scottish Migration, 1921-65: 'For Spirit and Adventure' (Manchester, 2007); Trevor Parkhill, 'Philadelphia here I come: a study of the letters of Ulster immigrants in Pennsylvania, 1750-1875' in H. Tyler Blethen and Curtis W. Wood, Jr (eds), Ulster and North America: Transatlantic Perspectives on the Scotch-Irish (London, 1997), pp. 118-33; Ronald A. Wells, Ulster Migration to America. Letters from Three Irish Families (New York, 1991).

3 The effect on the sending society has, however, become a significant theme in contemporary migration studies. See, as a starting point, Peggy Levitt, The Transnational Villagers (London, 2001).

4 Miller, Emigrants and Exiles, p. 137.

5 Estimates of the number of transatlantic migrants in the eighteenth century range from a low of 65,000 to a higher range of 250,000-400,000, with David Doyle's figures for the religious breakdown among them perhaps the best on offer. D. N. Doyle, Ireland, Irishmen and Revolutionary America, 1760-1820 (Dublin, 1981), pp. 52-74; Patrick Fitzgerald and Brian Lambkin, Migration in Irish History, 1607-2007 (London, 2008), p. 123.

6 Miller et al., Irish Immigrants in the Land of Canaan, p. 5, p. 436; Deirdre M. Mageean, 'Emigration from Irish ports' in Journal of American Ethnic History, xiii:1 (1993), p. 9; Patrick Griffin, The People with No Name: Ireland's Ulster Scots, America's Scots Irish and the Creation of a British Atlantic World, 1689-1764 (Oxford, 2001), p. 87.

7 Richard Mant, History of the Church of Ireland: from the Revolution to the Union of the Churches of England and Ireland (London, 1840), pp. 331-2; Thomas Olden, The Church of Ireland (London, 1892), p. 383; Miller, Emigrants and Exiles, pp. 150-1. 
8 Miller, Emigrants and Exiles, pp. 140-1.

9 W. E. Vaughan and A. J. Fitzpatrick (eds), Irish Historical Statistics: Population, 1821-1971 (Dublin, 1978), pp. 2-3; Fitzgerald and Lambkin, Migration in Irish History, p. 162.

10 Fitzpatrick, Irish Emigration, p. 3.

11 Donald Akenson has shown, however, that census and other data from some of these states - Canada and Australasia - can be employed to give rough approximations of the denominational distribution of Irish immigrants. See Akenson, Irish Diaspora, passim and Donald Harman Akenson, Small Differences: Irish Catholics and Irish Protestants, 1815-1922, An International Perspective (Montreal, 1988), pp. 42-86.

12 Akenson, Irish Diaspora, p. 52.

13 Between 1834 and 1901 Catholics lost 30\% of their numbers while the two main Protestant churches each declined by 19\%. Sean Connolly, Religion and Society in Nineteenth-century Ireland (Dundalk, 1985), p. 3.

14 Connolly, Religion and Society in Nineteenth-century Ireland, p. 5. It must be noted that the 1834 figure included an unspecified number of Methodists still affiliated with the Church of Ireland.

15 'The rest' includes various Congregational, Unitarian and Independent churches whose memberships were in the low thousands. Unlike Quakers, Methodists, and Baptists, they have received scant attention from historians of nineteenth-century Ireland. Connolly, Religion and Society in Nineteenth-century Ireland, pp. 5-6.

16 Miller et al., Irish Immigrants in the Land of Canaan, pp. 20-1, pp. 155-6; Robert E. Johnson, A Global Introduction to Baptist Churches (Cambridge, 2010), p. 111.

17 Quakers dwindled not merely because of emigration but also because of an increasing propensity to limit their family size. Richard T. Vann and David Eversley, Friends in Life and Death: The British and Irish Quakers in the Demographic Transition, 1650-1900 (Cambridge, 1992), p. 22, p. 50, pp. 244-5; David Hempton and Myrtle Hill, Evangelical Protestantism in Ulster Society, 1740-1890 (London, 1992), p. 132.

18 Norman W. Taggart, The Irish in World Methodism 1760-1900 (London, 1986), pp. 36-8.

19 R. Lee Cole, History of Methodism in Ireland 1860-1960 (Belfast, 1960).

20 Donald M. MacRaild, 'Wherever orange is worn: Orangeism and Irish migration in the $19^{\text {th }}$ and early $20^{\text {th }}$ centuries' in The Canadian Journal of Irish Studies, xxviii/xxix:2/1 (2002-2003), 98-117; David A. Wilson (ed.), The Orange Order in Canada (Dublin, 2007); Kevin Kenny, Making Sense of the Molly Maguires (Oxford, 1998); John Belchem, Irish Catholic and Scouse: The History of the Liverpool-Irish, 1800-1939 (Liverpool, 2007), pp. 126-7, 240; Tom Gallagher, Glasgow, the Uneasy Peace: Religious Tension in Modern Scotland, 1819-1914 (Manchester, 1987), pp. 54-5. 
21 On the more general historiographical neglect of the effects of emigration on the sending society - and attempts to address it in economic terms - see Franklin D. Scott, 'The study of the effects of emigration' in Scandinavian Economic History Review, viii:2 (1960), 161-74 and Beth J. Asch and Courtland Reichmann (eds), Emigration and its Effects on the Sending Country (Santa Monica, 1994). The latter includes Cormac Ó Gráda and Brendan M. Walsh, 'The economic effects of emigration: Ireland' on pp. 97-152.

22 W. F. Adams, Ireland and Irish Emigration to the New World from 1815 to the Famine (New York, 1932), pp. 16-67; Miller, Emigrants and Exiles, passim; Fitzpatrick, Irish Emigration, passim; Kevin O'Rourke, 'Emigration and living standards in Ireland since the famine' in Journal of Population Economics, viii:4 (1995), 407-21; Joel Mokyr, Why Ireland Starved: A Quantitative and Analytical History of the Irish Economy, 1800-1850 (London, 1983), pp. 230-60; David Fitzpatrick, 'The Disappearance of the Irish Agricultural Labourer, 1841-1912' in I.E.S.H., vii (1980), 66-92; Joel Mokyr and Cormac Ó Gráda, 'Emigration and poverty in pre-famine Ireland' in Explorations in Economic History, xix:3 (1982), 360-84; Cormac Ó Gráda, Ireland: A New Economic History 1780-1939 (Oxford, 1994), pp. 224-35; Cormac Ó Gráda. 'Irish emigration to the United States in the nineteenth century' in David Noel Doyle and Owen Dudley Edwards (eds), America and Ireland, 1776-1976: The American Identity and the Irish Connection (London, 1980), pp. 93-103; Eoin McLaughlin, 'Microfinance institutions in nineteenth century Ireland' $\mathrm{PhD}$ thesis, NUI Maynooth, 2009), pp. 236-84.

23 Schrier, Ireland and the American Emigration (2nd edn), p. viii.

24 Robert E. Kennedy, The Irish: Emigration, Marriage and Fertility (London, 1973); Timothy Guinnane, The Vanishing Irish: Households, Migration and the Rural Economy (Chichester, 1997); Patrick O'Sullivan (ed.), The Irish Worldwide: History, Heritage, Identity, 4: Irish Women and Irish Migration (Leicester, 1995); Janet Nolan, Ourselves Alone: Emigration from Ireland 1885-1920 (Lexington, 1989); Hasia Diner, Erin's Daughters in America: Irish Immigrant Women in the Nineteenth Century (London, 1983); Margaret Lynch-Brennan, The Irish Bridget: Irish Immigrant Women in Domestic Service in America 1840-1930 (New York, 2009); Pauline Jackson, 'Women in nineteenth-century Irish emigration' in International Migration Review, xviii: 4 (Winter 1984), 1004-20.

25 J. P. Dolan, The Immigrant Church: New York's Irish and German Catholics 1815-65 (London, 1984); P. J. Drudy (ed.), The Irish in America: Emigration, Assimilation and Impact (Cambridge, 1985); Carl Wittke, The Irish in America (Louisiana, 1956), pp. 88-101; James R. Barrett, The Irish Way Becoming American in the Multi-ethnic City (New York, 2012), pp. 57-104; Stephen Thernstrom, 'Irish Catholic life in Yankee city' in Philip 
Gleason (ed.), Catholicism in America (New York, 1970), pp. 58-64; Lynn Hollen Lees, Exiles of Erin: Irish Migrants in Victorian London (Manchester, 1979), pp. 164-212; Donald M. McRaild, Irish Migrants in Modern Britain, 1750-1922 (London, 1999), pp. 75-99; Ruth-Ann M. Harris, The Nearest Place that wasn't Ireland: Early Nineteenth-Century Irish Labor Migration (Ames, 1994), pp. 164-8; Patrick O'Farrell, The Irish in Australia (Kensington, 1986), pp. 105-14; Sheridan Gilley, 'The Roman Catholic Church and the nineteenth-century Irish diaspora' in Journal of Ecclesiastical History, xxxv:2 (Apr. 1984), 188-207. A more recent transnational study of the diaspora hints at possible rewards in more comparative diasporic religious history: Malcolm Campbell, Ireland's New Worlds: Immigrants, Politics, and Society in the United States and Australia, 1815-1922 (London, 2008).

26 Schrier, Ireland and the American Emigration, pp. 63-9; Gerard Moran, Sending out Ireland's Poor: Assisted Emigration to North America in the Nineteenth Century (Dublin, 2004), pp. 181-7; James O'Shea, Priests, Politics and Society in Post-Famine Ireland: A study of County Tipperary 1850-1891 (Dublin, 1983), pp. 124-5; See also G.R.C. Keep, 'Some Irish opinion on population and emigration, 1851-1901' in Irish Ecclesiastical Record, ser. 5, lxxxiv (Dec. 1955), 377-86; Robert S. Fortner, 'The culture of hope and the culture of despair: The media and 19th-century Irish emigration' in Eire-Ireland, xiii:3 (1978), 32-48.

27 David Fitzpatrick, 'Emigration, 1801-70' in W. E. Vaughan (ed.), A New History of Ireland V: Ireland under the Union 1801-1870 (Oxford, 1989), pp. 582-3; Moran, Sending out Ireland's Poor, passim.

28 Oliver MacDonagh, 'The Irish catholic clergy and emigration during the great famine' in I.H.S., v:20 (Sept. 1947), 287-302.

29 Miller, Emigrants and Exiles, pp. 124-30. For similar, if less explicitly put, arguments on the Catholic Church's bourgeois interest in perpetuating emigration, see Tom Inglis, Moral Monopoly. The Catholic Church in Modern Irish Society (Dublin, 1987), pp. 108-15; 173-5.

30 David Fitzpatrick, 'Review: The Irish in America: Exiles or escapers' in Reviews in American History, xv:2 (June 1987), 272-8; Fitzpatrick, 'Beloved country', 351.

31 Patrick J. Corish, 'Review: Emigrants and Exiles' in Catholic Historical Review, lxxiii:4 (Oct. 1987), 651-2; Patrick O'Sullivan, 'Introduction' in Patrick O'Sullivan (ed.), The Irish Worldwide. History, Heritage, Identity. Vol. 2 The Irish in the New Communities (Leicester, 1992), p. 9.

32 Fitzpatrick, 'Emigration, 1801-70', p. 599. Historians of contemporary Scottish migration have been more attentive in this regard, providing useful points of comparison: Donald E. Meek, "The fellowship of kindred minds': Some religious aspects of kinship and emigration from the Scottish Highlands in the nineteenth century' in Anon. (ed.), Hands 
across the Water: Emigration from Northern Scotland to North America - Proceedings of the $6^{\text {th }}$ Annual Conference of the Scottish Family History Society (Aberdeen, 1995), pp. 18-33; Donald E. Meek, 'Evangelicalism and emigration. Aspects of the role of dissenting evangelicalism in Highland emigration to Canada' in Gordon W. MacLennan (ed.), Proceedings of the First North American Congress of Celtic Studies (Ottawa, 1988), pp. 15-35; Marjory Harper, Adventurers and Exiles: The Great Scottish Exodus (London, 2003), pp. 338-48.

33 Donal A. Kerr, 'A Nation of Beggars'? Priests, People and Politics in Famine Ireland, 1846-1852 (Oxford, 1994), pp. 297-9; Moran, Sending out Ireland's Poor, p. 182; Miller, Emigrants and Exiles, p. 455.

34 Kevin Condon, The Missionary College of All Hallows, 1842-1891 (Dublin, 1986); Edmund M. Hogan, The Irish Missionary Movement: A Historical Survey 1830-1980 (Dublin, 1990).

35 MacDonagh, 'Clergy and emigration', 300-1; Maria Luddy, Women and Philanthropy in Nineteenth-Century Ireland (Cambridge, 1995), pp. 165-6; Much of the best work on this issue concerns female migration from the 1880s and into the twentieth century. Anne O'Connell, 'Charlotte Grace O'Brien' in Mary Cullen and Maria Luddy (eds), Women, Power and Consciousness in 19 $9^{\text {th }}$-Century Ireland (Dublin, 1995), pp. 231-62; Paul Michael Garrett, 'The abnormal flight: The migration and repatriation of Irish unmarried mothers' in Social History, xxv:3 (Oct. 2000), 300-43; Enda Delaney, 'The churches and Irish emigration to Britain, 1921-60' in Archivium Hibernicum, lii (1998), 98-114; Lindsey Earner-Byrne, 'The boat to England: An analysis of the official reactions to the emigration of single expectant Irishwomen to Britain, 1922-1972' in I.E.S.H., xxx (2003), 52-70; Jennifer Redmond, "Sinful singleness"? Exploring the discourses on Irish single women's emigration to England, 1922-1948' in Women's History Review, xvi:3 (2008), 455-76.

36 For much of Kerby Miller's work on nineteenth-century Protestant migration see a recent anthology of his work, Kerby A. Miller, Ireland and Irish America: Culture, Class, and Transatlantic Migration (Dublin, 2008).

37 An honourable exception is Bruce S. Elliott, Irish Migrants in the Canadas: A New Approach (London, 1988), which employed genealogical techniques to follow a group of Protestant families from Tipperary to Canada between 1815 and 1855. Also important is Fitzpatrick, Oceans of Consolation.

38 Emmet Larkin, 'Economic growth, capital investment and the Roman Catholic Church in nineteenth-century Ireland' in American Historical Review, lxxii:3 (Apr. 1967), 852-84; Emmet Larkin, 'The devotional revolution in Ireland, $1850-75$ ' in American Historical Review, lxxvii:3 (June 1972), 625-52; Emmet Larkin, 'Church, state and nation in modern Ireland' in American Historical Review, lxxx:5 (Dec. 1975), 1244-76; 
Emmet Larkin, The Historical Dimensions of Irish Catholicism (Dublin, 1997). The idea of a nineteenth-century 'devotional revolution' is not uncontroversial among scholars of Irish Catholicism. For alternative views on this timing, see Desmond Keenan, The Catholic Church in Nineteenth Century Ireland (Dublin, 1983); Thomas G. McGrath, 'The tridentine evolution of modern Irish Catholicism, 1563-1962: A re-examination of the 'devotional revolution' thesis' in Recusant History, xx:4 (Oct. 1991), 512-23; and Michael P. Carroll, Irish Pilgrimage: Holy Wells and Popular Catholic Devotion (Baltimore, 1999).

39 Emmet Larkin, The Consolidation of the Roman Catholic Church in Ireland, 1860-1870 (Dublin, 1987), pp. 103-5, 282-3; E. R. Norman, The Catholic Church and Ireland in the Age of Rebellion 1859-1873 (New York, 1965), pp. 144-8.

40 Desmond Bowen, Paul Cardinal Cullen and the Shaping of Modern Irish Catholicism (Dublin, 1983), p. 297. See Colin P. Barr, "An ambiguous awe": Paul Cullen and the historian' in Dáire Keogh and Albert McDonnell (eds), Cardinal Paul Cullen and his World (Dublin, 2011), pp. 428-30 for severe criticism of Bowen's book.

41 Hempton and Hill, Evangelical Protestantism, p. 149; Alan Acheson, A History of the Church of Ireland, 1691-1996 (Dublin, 1997), pp. 226-9.

42 Desmond Bowen, The Protestant Crusade in Ireland, 1800-70: A Study of Protestant-Catholic Relations between the Act of Union and Disestablishment (Dublin, 1978), pp. 189-91.

43 Brian Stanley, The Bible and the Flag: Protestant Missions and British Imperialism in the Nineteenth and Twentieth Centuries (Leicester, 1990); Susan Thorne, Congregational Missions and the Making of an Imperial Culture in Nineteenth-Century England (Stanford, 1999); C. A. Bayly, The Birth of the Modern World 1780-1914: Global Connections and Comparisons (Oxford, 2003), pp. 325-65; Andrew Porter, Religion Versus Empire?: British Protestant Missionaries and Overseas Expansion, 1700-1914 (Manchester, 2004); Norman Etherington (ed.), The Oxford History of the British Empire, Companion series: Missions and Empire (Oxford, 2005); J. P. Daughton, An Empire Divided: Religion, Republicanism and the Making of French Colonialism, 1880-1914 (Oxford, 2006); Stewart J. Brown, Providence and Empire: Religion, Politics and Society in the United Kingdom 1815-1914 (London, 2008); Esther Breitenbach, Empire and Scottish Society: The Impact of Foreign Missions at Home, c. 1790-c.1914 (Edinburgh, 2009); Hilary M. Carey, God's Empire: Religion and Colonialism in the British World, c. 1801-1908 (Cambridge, 2011).

44 Keith Jeffery (ed.), An Irish Empire?: Aspects of Ireland and the British Empire (Manchester, 1996); David Fitzpatrick, 'Ireland and the empire' in Andrew Porter (ed.), The Oxford History of the British Empire, iii: The Nineteenth Century (Oxford, 1999), pp. 495-521; Stephen Howe, Ireland 
and Empire: Colonial Legacies in Irish History and Culture (Oxford, 2000); Kevin Kenny (ed.), Ireland and the British Empire (Oxford, 2004).

45 See, for example, Jennifer Regan-Lefebvre, Cosmopolitan Nationalism in the Victorian Empire: Ireland, India and the Politics of Alfred Webb (Basingstoke, 2009); Patrick O'Leary, Servants of the Empire: The Irish in Punjab, 1881-1921 (Manchester, 2011); Barry Crosbie, Irish Imperial Networks: Migration, Social Communication and Exchange in Nineteenth-Century India (Cambridge, 2012); David Dickson, Justyna Pyz and Christopher Shepard (eds), Irish Classrooms and British Empire: Imperial Contexts in the Origins of Modern Education (Dublin, 2012).

46 MacDonagh, 'Clergy and emigration', p. 287.

47 Adams, Ireland and Irish Emigration, p. 65. 

Part I 

 \\ Talk of population: the clergy and emigration in principle}

Migration from nineteenth-century Ireland, no less than migration from any other society, was driven primarily by an economic imperative. Whether attracted by the promise of a better life in Britain or the New World, or feeling compelled to leave by a lack of opportunity at home, most Irish emigrants determined their course based on a rational assessment of their own and their family's best economic interests. ${ }^{1}$ Accordingly, as Professor David Fitzpatrick has eloquently observed, 'for its opponents as much as its advocates, the massive fact of emigration outweighed and enfeebled the expression of mere opinion.' ${ }^{2}$ Yet for long periods of the century, usually coinciding with the years of greatest departures, debates on the economic utility and desirability of emigration raged. As intermediaries between the poor and the state, clergymen had an undeniable and continuing interest in the questions that were thrown up: Was emigration a legitimate means of relieving acute distress or of improving Ireland's economic fortunes? If so, should it be encouraged, directed, or organised? If not, should it somehow be prevented? Who should take responsibility for such measures? Who or what was to blame for 'excessive' emigration? According to circumstances, these questions acquired varying prominence with different denominations, and clerical answers to them often evolved, and even became radically altered. This chapter, by tracing these processes, will assess how members of the clergy regarded emigration as an economic principle.

That Ireland's problems could be dispensed with alongside a portion of its population became a common belief in the depressed decades following the Anglo-French wars. Figures ranging from MPs to classical economists to, in this instance at least, a rather unromantic Poet Laureate, were convinced that an expanded and expanding post- 
Waterloo population could not be immediately provided for in any other manner. ${ }^{3}$ The idea derived from a widely held dogma of Irish 'overpopulation', in itself a rather problematic concept. As Joel Moykr noted some years ago, it is ordinarily difficult to define what overpopulation precisely entails, and as critics of his ambitious econometric investigation have since reinforced, the hard data necessary to test the thesis as applied to pre-Famine Ireland is too scant to be conclusive. ${ }^{4}$ What is true of economic historians today was equally true of contemporary political economists, yet there were few who did not propose 'overpopulation' as the base explanation for Irish ills. ${ }^{5}$

Such thinking relied heavily on the Reverend Thomas Malthus's Essay on the principle of population, which first appeared anonymously in 1798, and went through six modified editions up to 1826. An acknowledged classic of the relatively new discipline of 'political economy', and a sensation when published, the essay challenged an eighteenth-century orthodoxy that people formed part of a nation's wealth, and that a greater population meant a wealthier - certainly a potentially wealthier - nation. ${ }^{6}$ To Malthus, the inherent danger of unregulated population growth was a pressure on the means of subsistence so great as to induce, at best, a general drop in the living standards of the poorest classes, and, at worst, imminent disaster. $\mathrm{He}$ did not initially have Ireland in mind, but, particularly from the first of a number of localised 'pre-Famine famines' in 1816-17, many Irish observers, and latterly Malthus himself, came to find this prognosis strikingly applicable to the island. ${ }^{7}$

Within these Malthusian parameters the key question for Ireland was how to remedy the emerging imbalance. Two sets of options presented themselves. Firstly, efforts might be made to increase resources in line with population growth. Secondly, measures to reduce the population or the rate of its growth might be applied. Many contemporaries favoured prescriptions of the former sort. A host of proposals to introduce land reform, improve agricultural cultivation, and stimulate industry were forthcoming from pamphleteers of varying expertise, while most classical economists, as R. D. Collison Black has noted, were similarly focused on finding long-term strategies for economic development. ${ }^{8}$ Pitted against such capital-increasing plans were population-reducing ideas including Malthus's favoured 'prudential check', wherein 'moral restraint' and marriage later in life would produce fewer children, and the as-yet theoretical check of artificial birth control, which Malthus was not alone in rejecting on 
religious grounds. ${ }^{9}$ The problem which all of these proposals shared was their ambitious, long-term nature. Assuming they were possible at all, it would be several years before, say, industry could be sufficiently developed, or before the kind of cultural and moral transformation which Malthus envisaged could be brought about. Emigration, by contrast, appeared to promise immediate relief.

This perception gave emigration a new and broad appeal as a potential policy. Even for those who doubted its ability to single-handedly reverse the trend towards an overabundant population, it seemed to offer an expedient means of avoiding crisis until broader strategies could take effect. In 1817 the MP and economist Robert Torrens suggested in direct reference to Ireland that, 'until our institutions for extending education, and moral and prudential habits, have had time to give effect to a preventive check upon the number of births, there can be neither relief nor safety, except in emigration..$^{10}$ Torrens was also among the first to advocate emigration as an alternative to another proposal for more immediate relief of Irish distress which was gaining traction, namely an Irish poor law, which, as in England, would use a local property tax to create a minimal welfare safety net for the Irish poor; this was a constructed choice which did much to persuade others that state-directed emigration ought to be practised as the lesser evil. ${ }^{11}$ This was decidedly new territory. In the eighteenth century, in line with contemporary thinking, sustained emigration from Ulster had provoked the alarm of administrators and landlords alike. They feared, respectively, a weakening of the Protestant interest and a lowering of rents as competition for land became less fierce. ${ }^{12}$ Where once legislative efforts had been made to keep people in Ireland, ${ }^{13}$ a widespread acceptance of the Malthusian overpopulation principle meant that the opposite was now on the agenda.

There was great irony, therefore, in Malthus's own distinct opposition to any measure of assisted emigration. The first edition of his essay had entirely ignored the possibility of emigration as a check on population growth, while the second took care to dismiss it - as did others including J. R. McCulloch - as only 'a slight palliative', because it would simply create a vacuum to be filled by the unchanged reproductive behaviour of those left behind. ${ }^{14}$ Malthus was, in a sense, a double heretic on the issue, rejecting the previously accepted notion of government intervention to prevent emigration, but being equally leery of the new, opposing tendency. 'I have', he explained, 'always thought it very unjust on the part of Governments, to prohibit, or impede emigration; 
but I have doubted whether they could reasonably be expected so to promote it, as to undertake the responsibility of settling those who may wish to emigrate particularly as the superintendence of so powerful an agent has often the effect of weakening the exertions of the settlers themselves. ${ }^{15}$ Nonetheless, by the early 1830s, even Malthus expressed a grudging acceptance of the benefits of government emigration as a temporary measure, particularly - though he opposed it - before any poor law was to come into effect in Ireland. ${ }^{16}$

This gradual softening in Malthus's attitude can be traced in, but perhaps not to, his correspondence with Robert Wilmot Horton, an enthusiastic advocate of state-assisted migration, who also happened to be under-secretary at the Colonial Office. From this position, Horton successfully lobbied senior colleagues to assent to an experimental scheme of migration, which, he hoped, would prove that by the same stroke the underemployed Irish (and English) could be relieved and the underpopulated colonies could be peopled. Named for its overseer, Peter Robinson, the emigration took place in two stages, in 1823 and 1825, and involved the transfer of more than 2,500 applicants from the Blackwater region of north Munster to the Canadas, where they were settled on farmland to their apparent contentment. ${ }^{17}$ The problem was the cost. At an average of $£ 22$ per head, or $£ 53,000$ overall, the scheme was extravagantly expensive, rendering further government funding of emigration improbable. Notwithstanding this unconvincing result, Horton's continued agitation was rewarded (or perhaps bought off) with a select committee of inquiry into the subject in 1826. From this point, tied in with the growing discussion of a poor law, and spurred on by the emergence of another popular variation of the measure - Edward Gibbon Wakefield's 'systematic colonisation $^{18}$ - the debate on Irish emigration as a point of statedirected relief, far from lessening, intensified.

Oliver Goldsmith's Reverend Primrose was famously critical of men who 'merely talked of population', but after Malthus, there were many of his own vocation ready to do just that. ${ }^{19}$ The opinion of the Irish clergy on the point had been recognised as important from early on. Under the old dispensation, the Dublin and London governments had made direct appeals to Presbyterian ministers - occasionally known to encourage and even personally lead emigrants - to exercise their influence in a contrary manner and prevent the depletion of their congregations. ${ }^{20}$ Although happy to use the unusual attention from those in power to air their grievances, it is not apparent whether 
they had the ability or inclination to do any such thing. ${ }^{21}$ Later, Peter Robinson took care to consult with all local clergymen, and was especially surprised by the active cooperation of Catholic priests, who he had been warned would be overtly hostile. His gratitude was all the greater for his awareness of the fatal effect that 'their influence might have had if exerted against me upon the minds of the people, who were still suspicious that all was not right. ${ }^{22}$

Clerical involvement in the debate went beyond such local considerations, however. As the influence of Malthus demonstrates, what Boyd Hilton has termed the 'rage of Christian economics' did not bypass Ireland. ${ }^{23}$ Richard Whately, former professor of political economy at Oxford, and cheerleader for the new science, was appointed to the Church of Ireland archbishopric of Dublin in 1831, from where he continued to make the case against the introduction of an Irish poor law, and in favour of emigration as a preferable alternative. As he had previously elaborated, emigration offered a means of quick and permanent removal of a burden which might well be relieved more cheaply at home in the short term, but which would inevitably grow and require ever more relief in the longer term. ${ }^{24}$ Similarly, testifying before Horton's committee, John Jebb, the Anglican Bishop of Limerick, rejected the idea of sending money 'artificially' into Ireland via a poor law, on the grounds that it would teach people 'to rely on casual bounty [rather] than on their own continuous exertions'. Where aid was necessary, he vividly explained, emigration would prove, 'an immediate relief, it is what bleeding would be to an apoplectic patient [...] [it] would give relief to many and hope to all. ${ }^{25}$ A correspondent of the evangelical Anglican magazine the Christian Examiner went further still in this stance, suggesting that a poor law would prevent the rational and necessary exodus of motivated individuals from the overstocked labour market, negating whatever relief such 'natural' emigration already offered. ${ }^{26}$

Many prominent parish clergy of the established church came to echo the call for state intervention to encourage emigration. In 1810, the Cork rector Horatio Townsend had explained that, despite the county being even then 'overpeopled', resulting in a rapidly falling standard of living, the people were 'affectionately attached to their native soil' and 'no idea seems really distressing but that of leaving it.' 'Happiness', he concluded, foreshadowing David Ricardo, 'may sometimes be found in situations apparently most uncongenial.27 Yet less than a decade later, Townsend was arguing that 'the time 
of prescribing emigration is actually arrived, for [the country] cannot of itself support its population as human creatures ought to be supported'. ${ }^{28}$ To other Anglican clerics, emigration was a means, not merely of circumventing the introduction of a poor law, or of complementing its operation, but of effectually reducing poverty in and of itself. Michael Keating, rector of Ventry, wrote to Horton to assert that 'emigration on an extensive scale, and the concentration in villages of the scattered labouring population, would provide the most effective relief. ${ }^{29}$ There was, he suggested, a need for a consolidation of farmland and a drain of the surplus labourers by emigration; other proposals such as wasteland cultivation or public works would be more expensive and less useful. ${ }^{30}$ William Hickey, a Wexford rector better known as Martin Doyle, a prolific and popular author, disagreed slightly, telling a parliamentary committee that either home colonisation or 'emigration by wholesale' were necessary. ${ }^{31}$

There was, however, no Protestant consensus even on the central question, and a number of clergymen registered their opposition to any official sanction of emigration. Thomas Chalmers, the renowned Church of Scotland minister and economist who had an almost unrivalled influence on the social thinking of Irish evangelicals, rejected not only any extension of the poor law to Ireland, but also any alternative involving emigration. He expressed, like Malthus, 'an utter want of faith in the efficacy of emigration as a permanent scheme', although he was grudgingly willing to concede offering it as a temporary measure on the spurious basis that 'much fewer would avail themselves of it than we are disposed to anticipate. ${ }^{32}$ This was an error of judgment on which most Irish clergymen, of all denominations, could have set him right. Horatio Townsend's earlier perception of a peculiar attachment to the soil aside, independently funded emigration was proceeding at a considerable pace by 1830 , while, in the wake of the Robinson emigration, the Colonial Office had received thousands of petitions from Ireland requesting free passages to North America. ${ }^{33}$ It was clear that any extension of government funding for emigration would be enthusiastically taken up.

For a section of Protestant clergymen, already disturbed by the effects of the exodus from their flocks, government-assisted emigration was therefore a scandalous proposition. Richard Ryan, vicar of Rathcore, Co. Meath, disapproved of it on several grounds, including a quasi-Malthusian objection to using public money in attempting to produce consequences which should flow from the united and well 
directed exertions of society'. ${ }^{34} \mathrm{He}$ was also, however, dismayed by the failure to address the economic situation which, as he saw it, forced the self-directed migration of Protestants, asking the Archbishop of Armagh, 'Do we not owe something to the humbler classes of Protestants who are every day driven out, and ought not landlords be induced to make a slight sacrifice to protect them and strengthen their own influence[?] $]^{35}$ An anonymous Anglican clergyman was equally damning of the need for 'self-expatriat[ion]', seeing it as a 'cruel remedy' resorted to by desperate Protestants afflicted by poverty and persecution and deserted by those landlords and politicians who should protect them. ${ }^{36}$ The Dublin-based Dissenter Rev. J. B. McCrea seemed to sum up this growing anti-establishment feeling when he upbraided 'the political economy that would check the increase of the species, or curtail what is falsely called the redundant population' and told his congregation that 'the evils of emigration are already so numerous and so great, [that] the longer the practice is encouraged, the more will the pernicious effects be multiplied. ${ }^{37}$

These strong sentiments prompted action. Ryan and McCrea were among several clergymen involved in the 'Protestant Colonisation Society', which aimed, through the Dutch-inspired idea of 'home colonisation', to curb 'the growing national calamity of Protestant emigration..$^{38}$ Originally a sub-committee of the Orange Order, the society was established on an independent basis at the end of 1829 - noteworthy timing - in order to attract broader support. ${ }^{39}$ Its reception was mixed. Archbishop Beresford had previously been told by a relative that it represented 'much better work than processions or drums', but the Irish primate informed the Archbishop of Canterbury that, although he was not averse to keeping Protestants from emigrating, this plan 'originated in party spirit' and 'would serve as a provocation to continued hostility. ${ }^{30}$ Meanwhile, in his analysis of the Irish economy, J. E. Bicheno dismissed it as the 'preposterous' sub-Cromwellian work of 'zealots. ${ }^{41}$ This alienation of moderate Protestant opinion may have been the fatal handicap. An 1832 report of the society claimed that twelve families who had intended leaving the country had already been settled on a thousand acres bought in Co. Donegal, and another fifty had been selected for settlement, but it also displayed an ultimately justified anxiety as to where further funding was to come from. ${ }^{42}$ While ostensibly the society had enunciated sentiments diametrically opposed to those of Whately, Townsend, et al., a supportive comment of Michael Seymour illus- 
trated the sectarian reality: 'If emigration must take place, let it be a Popish emigration; an increase in our exports of this class would indeed be a blessing to this country. ${ }^{43}$

Catholic clergy seemed to be in inadvertent agreement with Seymour, although it is, perhaps, the relative absence of public Catholic commentary on the issue during this period that impresses most. The economist Harriet Martineau, who saw emigration as a crucial part of any plan of relief, cautiously had her fictional Irish priest Father Glenny sit on the fence on the issue: emigration might be less painful than transportation, but it might also be avoidable through "wiser social management. ${ }^{\text {'4 }}$ Yet, speaking before a parliamentary committee on the state of Ireland in 1825, Thomas Costello, a real-life Limerick parish priest, was unequivocal. He communicated positive second-hand knowledge of the Robinson scheme, and noted 'a very great disposition to emigrate' among his parishioners. Many of them had gone to Charleville in the past year to apply for places in the second phase of the scheme, encouraged by letters from already-departed friends. 'I think' he concluded on the general point of state-aided emigration, 'it would be very desirable to remove [the mendicant class]; those that are youthful or likely to become industrious in another country.' ${ }^{45}$

The leading Catholic social thinker of the day, the Bishop of Kildare and Leighlin, James Warren Doyle - 'J.K.L.' as readers knew him addressed the point in more substantive terms. In an 1825 edition of his widely read Letters, Doyle appeared to be wholly enthusiastic about well-directed Irish emigration to Britain, suggesting that it could even be 'the natural mode of relief'. ${ }^{46}$ Yet, writing to Thomas Spring Rice two years later, he observed pithily of Horton's continued lobbying: 'We are much occupied here with the emigration plan. I have no doubt it is unwise in principle, but may be a useful, nay, a necessary expedient to relieve our present distress. ${ }^{47}$ This later equivocation almost certainly reflected a growing pre-occupation with an Irish poor law as the primary means of relief rather than any cooling towards emigration per se, since Doyle continued to be a leading proponent of both. His advocacy was to the fore in the 1830 'Poor inquiry' chaired by Spring Rice, where he made a spirited and perhaps influential case for a poor law that incorporated emigration. While denying that Ireland was overpopulated, he expressed concern that those he saw leaving his diocese were 'the cream of the people', those who had the means to emigrate, and who left the country more distressed by their removal, and he therefore proposed a public programme of emigration, part- 
funded by landlords, which would 'send away some good, and some not so good, and so relieve the parochial funds of a portion of the burthen upon them. ${ }^{\text {' }}$

In the 1820s and 1830s, therefore, there were both Protestant and Catholic clergy who were in principle in favour of state encouragement of emigration, though often for very different reasons. There was a strain of Anglican opinion that simply preferred emigration to a poor law, while there was a tendency amongst Catholic clergy to see emigration as part of the overall solution to Irish poverty partially since, it was clear, their congregations increasingly felt the same. There was also another significant body of Protestant clergy that rejected any move which might increase the already heavy flow of Protestant emigrants, and, in the absence of government or landlord action to prevent the same, was prepared to intervene. The question arises as to how representative these sentiments were of the lower ranks of the clergy, who were, after all, closer to the everyday reality of emigration, and the possible effects of any economic doctrine applied from on high. An analysis of the extensive clerical testimony before the 1833-36 Poor Inquiry - which questioned over a thousand clergymen of all denominations on the subject - offers some answers.

The Commission for inquiring into the condition of the poorer classes in Ireland (hereafter the Poor Inquiry) was constituted under the chairmanship of Richard Whately in 1833. The archbishop had a well-known and long-standing preference for assisted emigration - and increasingly, for the emerging Wakefieldian, self-supporting form of systematic colonisation - over any significant state provision of poor relief. ${ }^{49}$ It is therefore unsurprising that his Inquiry sought information on emigration, both as it already operated, and as it might impact as a government policy. Testimony on this and other points was gathered by the Commission in two distinct ways. Firstly, questionnaires were distributed to prominent members of local communities and over a thousand replies received - the overwhelming majority - were from clergymen. Secondly, agents of the inquiry travelled the country convening 'baronial examinations', or public meetings, at which clergy of all denominations were usually present and frequently vocal.

Each method of inquiry adopted slightly different approaches. The questionnaires asked the following: 'What number of emigrants, and of what description, have left your parish during each of the last three years?; To what country have they gone?; Have they received 
any, and what, assistance for the purposes of emigration and from whom?'50 The baronial examinations also asked who and how many had emigrated, but, in addition, wondered what effect their departures had had on wages, how many would need to leave to allow those left behind to earn a living wage of $10 \mathrm{~d}$. a day, and whether it was thought people might be willing to avail of any emigration scheme offered. The baronial examinations therefore called for a good deal of instant speculation that many witnesses simply declared beyond them, while the questionnaires seem by their nature to have prompted more reflective responses, though again, the specifics were beyond the knowledge and perhaps the interest of a minority of respondents.

Nonetheless, the appendices of the Poor Inquiry provide a useful snapshot of pre-Famine clerical attitudes towards emigration, and from there, familiar patterns emerge. Indeed, using the questionnaire data, it is possible, via the admittedly crude means of content analysis, to quantify the differences in outlook. A warning should be attached here: the factual nature of the questions posed meant that the respondents' opinions were not directly sought, and were therefore not always given, directly or otherwise. For example, it is impossible to say from his responses here what William Hickey thought on the subject, even though his earlier testimony before Horton's committee marked him out as a proponent of a measure of emigration. ${ }^{51}$ Thus, of 1,085 clerical testimonies, it is necessary to set aside 839 which, like Hickey's, simply provide factual information on emigration and do not betray a stance on the issue one way or the other. This leaves 246 testimonies, a number further reduced when the 'don't knows', i.e. the 134 clergy whose answers consisted of 'no emigration' or simply ' - ' are taken into account. This leaves a smaller sample of 112 clerical opinions on emigration from which tentative impressions may be drawn.

It must firstly be noted that there was a considerable imbalance in clerical responses to the questionnaires, with Catholic clergy providing just under a third and Protestant clergy more than two thirds of the total. This could reflect a Catholic reluctance to engage with state surveyors, a greater intellectual engagement with social issues, including emigration, on the part of Protestant clergy, or simply differences in clerical workloads. However, notwithstanding this imbalance, there were significant differences in the breakdown of sentiment within each party. Catholic priests, it would appear, were overwhelmingly in favour of assisting emigration, by a factor of more than ten to one. Within the smaller sample of priests whose views 
on emigration can be parsed, this translates into $91 \%$ of priests who were favourable towards emigration and $9 \%$ who were critical of it. If we factor in the larger sample of all Catholic responses, whether they contain a discernible opinion on emigration or not, we see that $11 \%$ of Catholic respondents were in favour of emigration and just $1 \%$ voiced any criticism of it. Protestant clergy were much more evenly matched. Taking, once again, the smaller sample of those who offered up an opinion reveals that $48 \%$ of Protestant clergy who expressed a view on emigration were positive towards it and $52 \%$ were negative towards it. Translating this to the larger sample shows that $4.3 \%$ of total Protestant responses contained positive feelings towards emigration, and $4.8 \%$ were negative about emigration, with the relatively small number of Presbyterian clergy within their number tipping the balance towards the negative. The breakdown for Presbyterian ministers was, within the smaller sample, $45 \%$ positive, $55 \%$ negative or, within the larger sample, $5 \%$ positive, and $6 \%$ negative.

A few points can be made on the basis of the above. Firstly, a significant overall majority of those clergy who used the questionnaires as an opportunity to offer their unbidden opinions of emigration were in favour of employing it, somehow, as a relief measure. Secondly, Protestant clergy, whether Anglican or Presbyterian, were far more likely than their Catholic counterparts to hold - or at least feel the need to express - negative feelings towards emigration. Thirdly, Catholic clergy at this point appear to have had nothing approaching a systematic critique of emigration, either as an already-existing phenomenon, or, importantly, as a potential government measure of relief. With these points in mind, it is worth exploring some of the detail of the testimony.

It has been noted that in earlier discourse, positions on emigration tended to interlink with positions on the poor law, and there is some indication in correspondence appended to the Inquiry that many Anglican clergy agreed with the Inquiry chairman insofar as, were an emigration plan to be enacted, 'the necessity of poor-laws [would be] superseded, or at least confined to a limited scale. ${ }^{52}$ However, the diverse origins of pro-emigration impulses amongst clergy are made clear in some of the few cases where witnesses admit to providing financial aid for the purpose. A Catholic priest in Queen's County helped raise $£ 108$ to aid in sending away 140 local evictees; two Anglican vicars in Co. Down used parochial funds to enable some parishioners to join previously departed relatives; while a vicar in Co. 
Donegal 'assisted some few families with from $£ 20$ to $£ 30$ each, who were tenants of my own private property, and whose farms I wished to get to increase others. ${ }^{53}$ Therefore, anything from apparently pure humanitarian concern to self-interested economic realism could be responsible for the cross-denominational feeling that emigration and its assistance, in some form, were a necessary step towards economic recovery and the elimination of poverty.

The above examples should not be taken to mean, however, that Protestant clergymen alone saw emigration in its wider economic context. Their Catholic counterparts were equally capable of seeing emigration in terms beyond the personal hard-luck story. Anglican and Catholic responses to the admittedly leading question of the baronial examiners as to how many people should be removed in order to have a positive effect on wages at home were all but unanimous. A 'great and constant' emigration was required, with anything between a quarter and a half - there was near consensus on a third, perhaps the favoured suggestion of the commissioners - of the local labouring population needing to be assisted if those left behind were to thrive. ${ }^{54}$ There also appears to have been wide agreement that such proportions of people would willingly avail of any opportunity to go. Indeed, mention of those who had already managed to emigrate frequently led to the pleading assertion that 'more would be glad to do so if they had the means. ${ }^{55}$ A Westmeath clergyman elaborated that 'every effort is made for this purpose [emigration]; it is their only hope $[\ldots]$ they have hopes that in time a free passage will be granted. ${ }^{56}$

The case for a free passage was also made indirectly, on the basis that the independent system was in several respects inadequate: it involved great hardship for emigrants themselves, it could leave loose ends, and it may even have increased the distress of those who remained. A Catholic priest in Cork related several stories of desperate parishioners crossing the Atlantic without shoes, hats and coats, and leaving their wives and children behind to fend for themselves until such time as they could be sent for. ${ }^{57}$ On the other hand, instances of farmers selling up and defrauding their creditors in order to fund their emigration seem to have particularly irked Anglican clergy in the same county, who in opposing the manner rather than the fact of these departures seemed to imply a receptiveness to a funded system which would avert such abscondments. ${ }^{58}$ Similarly, the Anglican dean of Clogher bemoaned the damaging lengths to which some went to fund their departures: 
a practice has become too common of young able-bodied men selling their interest in their farms and emigrating with the produce, without making any provision for the maintenance of parents to whom the lease was originally made, and who thus become burdens on the public, although they ought to be, and have hitherto been, in comparatively comfortable circumstances. ${ }^{59}$

Some Catholic clergy agreed with the dean's admonishment. A Louth priest spoke of young emigrants 'rather embarrassing their relatives in endeavouring to procure means to defray their expenses'; another cleric complained of the departed 'leaving their parents at home, distressed from providing means for them to emigrate, and from the loss of their assistance. ${ }^{60}$ The crux of the problem was best expressed by a Kerry priest, however: 'Their emigration is rather of disservice; they have taken some means with them; they have left the infirm and poor, the real incumbrance of society, behind. ${ }^{61}$ The key, then, for many clergy was simply that the wrong kind of emigration was occurring, a kind that increased rather than lessened domestic distress.

This attitude needs to be distinguished however, from a rather more forcefully expressed sentiment that regretted not simply the mode and residual effects of departures, but the loss of the departed themselves. This was partly an economic concern. Certainly, the idea that only the 'cream' of the population had the ability to emigrate in the pre-Famine decades has some credence. The average Atlantic passage fare up to mid-century of ninety shillings was considerable, and coupled with ancillary transport and provisions costs, was equivalent to about two years rent. Such a sum was difficult enough to come by for a small farmer, let alone a labourer or cottier. ${ }^{62}$ Therefore, while it is not possible, as Mokyr has noted, to establish absolutely the economic calibre or potential of those who left Ireland, it is safe to say that a disproportionate number of both Protestant and Catholic emigrants between 1815 and 1845 were of a somewhat elevated social status. ${ }^{63}$ However, while the emphasis seems superficially to have been on the inherent entrepreneurial or leadership qualities of those lost, there was also a cultural and religious element to the regret. These sentiments were almost exclusively Protestant and largely based in Ulster. Hence, Alexander McIlwain of Down complained of the emigration of 'several young men, and many of them the ornaments of society in the sphere in which they moved'; William Dickey of Donegal regretted that 'the persons who emigrated are generally the children of decent farmers, who are likely to make useful members of 
society [...] our neighbourhood is yearly drained of some of its most spirited and industrious youths'; and Samuel Butler of Londonderry believed the emigrants from his area to have been 'the flower of the people for activity and intelligence, and their loss [...] a very serious one to the public. ${ }^{34}$ Two Church of Ireland clergymen in Limerick put the point across most openly; emigration, they complained, was depriving them of 'the chief ornament of [their] church. ${ }^{3}{ }^{65}$

Linked to these views was the repeated assertion by Protestant clergy that 'Roman Catholics emigrated from distress, and the Protestants from the distracted state of the country' ${ }^{66}$ A Wicklow session of the baronial exams was given a more explicit interpretation: 'one great cause of the emigration among Protestants ha[s] been the disturbed state of the country, and the violence of the Roman Catholic population'. ${ }^{67}$ Meanwhile in Sligo, it was said 'the Protestants see their numbers daily diminishing, and they think if they remain at home they will be exposed to violence. ${ }^{68}$ It is certainly the case that pockets of pre-Famine Ireland were convulsed by agrarian violence. However, it is far from clear that significant numbers of Protestants emigrated purely because such violence was specifically targeted at them for religious reasons. Certainly, Dickson gave little weight to feelings of religious persecution as a cause of emigration in the previous century, and Michael Beames has dismissed claims that agrarian agitation in the 1830s targeted persons on a sectarian basis. ${ }^{69}$ Indeed, George Cornwall Lewis, who was charged with critiquing Whately's third report, was specifically told by 'a person well-acquainted with the facts' that 'the motive to emigration with the Protestants is self-interest, and a desire to better their condition, and not religious persecution. ${ }^{70}$ This is not to suggest that the fear of sectarian violence or of being vastly outnumbered as the Catholic population rose ever higher did not figure at all in Protestants' decisions to emigrate; but it is to suggest that it was by no means the main reason for those decisions. ${ }^{71}$ Nonetheless, a number of Protestant clergy were keen to relay precisely the opposite impression to the Poor Law Commissioners. A Tipperary rector claimed that 'the only emigrants are the useful industrious yeoman, who has been driven from his native home by fear of the religious and political agitation' and his colleague in the same county agreed that 'a good many have left this parish, mostly Protestants and I fear many more will shortly leave their old habitations, to seek for peace and quietness in every foreign land where they think such is to be obtained.72 This assump- 
tion also stretched northwards. One Presbyterian minister saw fit to emphasise that little emigration had taken place from his area of late since 'our parishes have been, and still are, perfectly tranquil and quiet', clearly implying that political or sectarian unrest and not economic concerns had been the chief cause of Protestant outward migration. ${ }^{73}$

However, there was also a concurrent rationale that blamed Protestant emigration on the fact that 'their interests are neglected by those who should protect them, by which was meant both the Government, which was responsible for 'the manner in which the political affairs of the country have been carried on of late' - a reference to Catholic Emancipation and Established church reform - and, most of all, the landlords, who 'now care no more for a Protestant than for a Roman Catholic.74 This latter point evoked the arguments of the by-now defunct Protestant Colonisation Society, and was mentioned here particularly in relation to the (Methodist) Palatines of Limerick, who were leaving in large numbers owing to, it was said, 'the difficulty they found in obtaining farms. ${ }^{75}$ Therefore, according to a significant section of their clergy, both political and economic insecurity, much of it blamed on perceived religious persecution, was driving Protestants away; 'unprotected from lawless aggression of mobs, and deserted by government', 'they scarcely consider[ed] their lives or their profession secure. ${ }^{76}$

There is little evidence at this juncture of a similarly politicised interpretation of the existing stream of emigration by Catholic clergy. Only one priest, Robert Taylor of Cork, exercised what can be seen as bald political opportunism, asserting that he 'never knew or heard of so many going to America in one season as are preparing for this next spring, in consequence of being told they must pay the tithe. ${ }^{37}$ Though there was a genuine feeling of grievance over the tithe, most Catholics expressed it far less drastically than Taylor suggested and simply refused to pay, a course of action that had the influential support of Bishop Doyle. ${ }^{78}$ It seems highly unlikely, therefore, that this was the primary reason for any mass flight from Taylor's congregation, or any other, and perhaps the fact that he merely predicted (or threatened) such rather gives the game away. Other anti-emigration sentiment expressed by Catholic clergy was of a relatively benign nature. Even the innocuous observation of John Hanna of Down that, 'People here [are] unwilling to emigrate, and, could they exist at all, cleave to their native place' was a rarity. ${ }^{79}$ 
Therefore, at this point, Catholic parish clergy regarded emigration with relative equanimity, and in contrast to many Protestant clergy, did not assign any blame for departures from their flocks. There even appeared to be general agreement with Bishop Doyle that emigration, properly managed, was a potentially useful measure. Poor Inquiry testimony also illuminates the split in Protestant opinion on the issue, between those who advocated emigration as a sensible economic safety valve, and those who decried it as a kind of banishment. On balance, it would seem that more of the lower-ranked clergy fell into the latter category. As the Presbyterian preacher John Brown of Aghadowey bluntly said of the government's tentative foray into aiding emigration, 'such drivellers as Wilmot Horton may think well of emigration, but I look on people as the wealth of a nation'.80

Like the rest of its proposed measures, the emigration clauses of Whately's report - which suggested local schemes of 'extensive emigration', half paid for by the state and half by landlords, and that Poor Law Unions be able to borrow from central government for the same purpose - went unimplemented ${ }^{81}$ But the issue did not rest there. By 1845 there were as yet only tentative signs of disquiet among Catholic clergy about increasing emigration. The incipient Christian socialis[t]', Thaddeus O'Malley, for example, argued that emigration should be a measure of last resort only. ${ }^{82}$ Yet in the absence of government intervention, there was a small flowering of private attempts to organise and direct the movement from Ireland in which both Catholic and Protestant clergy played a part. ${ }^{83}$ Two of these were initiated by politicians who had shown previous sympathy towards Wakefieldian 'systematic colonisation. ${ }^{84}$ The Limerick Emigrants' Friend Society, founded in 1833 by William Smith O'Brien, had cross-denominational support for the distribution of information to would-be emigrants, and if its secretary, Rev. Michael Keating, was to have his way, there were ambitions for the society to co-operate with the Colonial Office in a much broader scheme of mass colonisation. ${ }^{85}$ In 1843 Daniel O'Connell, who was no fan of Horton's proposals, ${ }^{86}$ established the Catholic Emigration Society, which hoped to regulate emigration and boasted of 'the marked approval and support of the Venerable Prelates and the influential clergy of the Catholic Church, as well as of Father Mathew, the apostle of temperance. ${ }^{87}$

Both of these societies fizzled out in relatively short order, while another, the North American Colonial Association of Ireland (N.A.C.A.I.), spanned both of their existences but had equally 
negligible results. Its initial aim was to acquire 500,000 acres of forest land in British North America and superintend the settlement of emigrant families who would rent and clear portions of this land. ${ }^{88}$ Wakefield himself became directly involved in 1835, travelling to Canada as agent of the association and building a canal on the N.A.C.A.I.s land, ultimately settling few people but losing a great deal of shareholders' money in the process. ${ }^{89}$ The initial response of the governor-general of Canada, that the plan was a 'horrid swindle', seemed vindicated. ${ }^{90}$ It is interesting to note, however, that one of the shareholders was Daniel Murray, Catholic Archbishop of Dublin, who invested $£ 10$ in five shares in 1839 , and seems to have continued his relationship with the Association until at least $1846 .{ }^{91}$ A poor investment, as it turned out, but one that Murray might have hoped would yield good results for those migrated. According to Thomas Rolph, a former Canadian government emigration agent, on meeting the Irish bishops by invitation in Queenstown in 1839, he had convinced them that Canada was preferable to the United States for emigrants and 'there appeared to be a determination on the part of those prelates to encourage it by all means in their power. ${ }^{92}$

However, clerical testimony before the Devon Commission on the eve of the Famine suggested that, while the mix of views among Protestant clergy had hardly changed, the apparent Catholic openness towards emigration-as-relief was beginning to fade. Several priests still made the familiar economic case for encouragement of departures, often in bold terms. Michael Fitzgerald of Ballingarry, Co. Limerick, for example, argued for 'emigration on the largest practicable scale possible, and on the principle of the emigration to Canada under the sanction of the government in 1822.' 'This', he suggested, 'is the only effectual remedy' for agricultural distress. ${ }^{93}$ However, James Davy of Kilworth, Co. Cork was among a handful of clergymen who communicated a more emotional response to the issue, one that simply preferred any alternative. Emigration was, he said, 'a great evil to the country $[\ldots]$ my feelings are averse to emigration. I think the people could be better and more usefully employed at home. ${ }^{94}$

Davy's view, rather than Fitzgerald's, was the harbinger of things to come. The crisis outflow during and after the Famine - sometimes attended by horrendous on-board and port-of-arrival suffering encouraged a hardening of public rhetoric among Catholic clergy. Increasingly, clerical spokesmen interpreted the advocacy of emigration, not as a sincere effort to provide relief, nor even as a more general 
economic plan from which relief for individuals might unintentionally flow, but as a component of a wider policy of deliberate depopulation, or, worse still, 'extermination'. Certain clerics may have been able to frame their own proposals for emigration assistance in terms of welfare, but the intentions of landlords and politicians were always to be suspected. ${ }^{95}$ The change was clearly apparent in the hierarchy's response to one of several attempts to convince the government that some form of colonisation might mitigate the effects of the crisis. In 1847 John Robert Godley, a Leitrim Poor Law guardian and landlord's son, proposed the transfer at state expense of two million people to a 'new Ireland' in Canada. This would require the participation of accompanying clergy. As he explained to Parliament, 'the nucleus of an Irish Roman Catholic Emigration must be ecclesiastical..$^{96}$ In the end, Godley's plan, like others, called for an application of public money which 'a vacuous and callous dogma' among administrators would not allow, but his inexpert wooing of the hierarchy nonetheless provoked a trenchant public response. ${ }^{97}$

Godley had written to every Catholic bishop outlining his plans. In April Edward Maginn, co-adjutor Bishop of Derry, responded publicly. Dripping with sarcasm, his letter left no doubt as to his opinion of both the proposal and, pertinently, the committee of landlords which Godley had assembled behind it. In part, Maginn objected to the destination; if emigrants there must be, they would go to 'the land of the brave and the home of the free' he insisted, rather than to where the 'British lion' might still exercise a pernicious influence over their lives. He also cast doubt on the motives of those pushing the plan, and warned that 'no matter how fair the device might appear, or how sunny the prospect held out', an 'offering from such a source must contain, like the basket presented to Cleopatra, an adder concealed beneath the flowers. ${ }^{98}$ Archbishop John MacHale of Tuam was similarly suspicious of the class and political allegiances of the originators and supporters of the plan. For him they induced a prima facie presumption that it is deserving of utter condemnation. ${ }^{99}$ This unambiguous public broadside was not the full story, however. Godley later told a parliamentary committee that he had been given 'very strong assurances of support' from 'many' Catholic clergy, and it appears that at least one bishop was amongst them. ${ }^{100} \mathrm{~A}$ week before Maginn's letter appeared in the press, Godley privately informed Lord Monteagle that he had 'received today the enthusiastic approbation and adhesion of the Bishop of Limerick (R.C.)', and that 
William Monsell was planning to consolidate support for the plan in Limerick by way of a public meeting, although this did not evidently take place. ${ }^{101}$

Emigration arranged by individual landlords, particularly where connected to evictions, met with similarly divergent public and private responses. James Donnelly has estimated that half a million individuals were evicted between 1846 and 1854, but only a pitiful proportion of those were given any financial assistance to escape destitution or the overwhelmed workhouse system. ${ }^{102}$ Local priests, therefore, in common with tenants, generally welcomed any passage money that was forthcoming in such instances. Some defended the more generous landlord schemes of the pre-Famine and early Famine period against allegations of compulsion, and even the more notorious, parsimonious schemes of the later 1840s did not provoke the kind of disquiet that might have been expected. ${ }^{103}$ The historian of the Palmerston estate emigration found Sligo priests objecting not to the scheme itself, nor even to its many shocking inadequacies, but, on temperance grounds, to one of its few generous measures - provision of a glass of rum punch on board ship each Sunday. ${ }^{104}$ Emigration from the Lansdowne estate in Kerry was equally mean in its application, though it had the silent support of the prominent local parish priest, John O'Sullivan, who ignored press calls for him to publicly denounce it. ${ }^{105}$ Finally, the migration scheme of the later-assassinated Roscommon landowner Denis Mahon was condemned by Monsignor McDermott of Strokestown partly on the basis that Mahon had not provided for all of his ejected tenants with Atlantic passages; indeed, another local priest, Henry Brennan, had urged Mahon to begin an emigration scheme earlier in the year. ${ }^{106}$

This was not apparent in the public rhetoric which addressed the relationship between landlords and emigration. By the end of the Famine, and as the outward flow reached its peak, the polemics of Repeal and especially Tenant Right meetings - routinely attended by priests - were roundly denouncing all emigration as the expatriating insult added to the injury of eviction; as a damaging, involuntary and avoidable banishment. ${ }^{107}$ Moreover, George Browne, the Bishop of Elphin, in whose diocese Strokestown was located, explained in an open address to Lord Shrewsbury what he regarded as the illusion of the emigrants' free will. There is, he wrote, 'a vast distinction between what is termed in human acts voluntarium simpliciter and voluntarium secundum quid. Landlords, said Browne, were in pursuit of their own 
interests and of land consolidation, presenting their tenants with a stark choice: destitution or emigration. ${ }^{108}$ The point, however, is that even this choice was only rarely given, and indeed did not appear to apply in Strokestown, meaning, as David Fitzpatrick has argued, that landlords as a class were condemned, both in public and in local memory, on the wrong grounds. ${ }^{109}$ It was their collective failure to properly satisfy the enormous demand from their ejected tenants for passage money, rather than their limited and inadequately resourced individual forays into migration, which was their - and indeed the government's - real shortcoming. ${ }^{110}$

Just as Whately's presence on Godley's committee was true to pre-Famine form - though he waited until he had consulted associates including Nassau Senior before allowing his name to go forward - Protestant clergy were no more united in their reaction to proposals for organised emigration during the Famine than they had been before. ${ }^{111}$ Several of them contacted government officials to register their feelings on the matter. A 'resident rector' of Leinster wrote to the Lord Lieutenant's office in favour, ${ }^{112}$ and in a later address to the new Lord Lieutenant, the Remonstrant Synod of Ulster (a body of non-subscribing Presbyterians) called for 'a well-regulated and extensive system of colonisation. ${ }^{113}$ Set against this were an Anglican minister from Cavan who brought up the familiar Malthusian objection to emigration - 'it is like tapping the dropsical patient [...] the disease very soon acquires additional strength' - and two Ulster clergymen, who lamented the lasting injury outward migration caused to the Irish economy. ${ }^{114}$ Given that the balance had tipped so far in its favour, there was also a new and significant concentration on the effects of Catholic emigration, as opposed to those of Protestant migration.

The response of Catholic churchmen had undergone a dramatic transformation. Where previously priests and bishops alike presented as 'a body of men who accepted, without much thought, the conventional social and political ideas of their day', they were now, in public discourse at any rate, emerging as critics, and perhaps equally unthinking ones, of any emigration advocated by the landed class and of any emigration or colonisation policy put before government. ${ }^{115}$ Increasingly, continued self-expatriation was blamed on the negligence and heartless, self-interested political economy of those two entities. ${ }^{116}$ Ireland, they argued, was not overpopulated. There was sufficient land for all if only it was better cultivated or nurtured from a state of waste. ${ }^{117}$ Though there remained many Catholic clergymen 
who were privately willing to admit that emigration, whether organised or self-directed, offered the only immediate remedy for the misery they saw around them, in public an aggressive and condemnatory line was now adopted.

This changed attitude, increasingly matched by private reservations, was amplified during later peaks of emigration, and was bound up with anger at the failure of government and landlords to concede land reform. For many Catholic clerics, all emigration could be traced to the iniquitous power of landlords to evict at will, and to the successive governments which sustained that power. High-profile incidents such as the 1861 evictions at Derryveagh, Co. Donegal tended to reinforce that perception, although on that occasion, as the Belfast News Letter took pains to emphasise, the emigration was arranged and paid for by an Australian Catholic Church fund. ${ }^{118}$ Daniel Cahill, an immensely popular priest - one American contemporary said of him 'another humbug, but the Irish seem to worship him' - and roving orator, whose letters and speeches featured regularly in the Catholic press was a prominent exponent of this trope, routinely referring to 'the extirpation of the Irish population. ${ }^{119}$ In 1853 he addressed the Prime Minister on 'the ruthless extermination of the needy Orange landlords of Ireland': 'You speak of your just laws on this subject,' he said, 'we point to the emigrant ship.' ${ }^{120}$

Another vocal priest, James Redmond of Arklow, Co. Wicklow, insisted that landlords had a choice. They 'could tear up the tenantry by the roots, and fling them like weeds to perish on the earth's surface, to pine in the poorhouse, to be submerged in the ocean, or to be swallowed up in the insatiate maw of the internecine war of America' or they could grant tenant right. ${ }^{121}$ Redmond furthermore excoriated the then Lord Lieutenant as 'confessedly' an 'advocate of wholesale depopulation', who was 'labouring to make Ireland a land of flocks and herds and as a matter of necessity causing the expatriation of millions of Irishmen from the land of their birth. ${ }^{122}$ In the 1860 s, these sentiments also frequently found their way into pastoral letters and the extensive private correspondence of Irish prelates with Dr Tobias Kirby, the Rector of the Irish College in Rome, and they played a role in bringing about the National Association - an abortive episcopal foray into politics - in $1864 .{ }^{123}$

All of this was reminiscent of the anti-government and selectively anti-landlord rhetoric of the Protestant Colonisation Society. ${ }^{124}$ It was also, in part, a response to the surprisingly durable belief of economic 
commentators that continued emigration offered a (partial) solution to Ireland's problems. In the immediate aftermath of the Famine, such thinking had been almost universal, if muted. An 1854 paper by John Locke of the Statistical Society of London purported to address 'excessive emigration and its reparative agencies' but having judged that the recent outflow had 'emptied the workhouses and raised wages', Locke concluded that only further emigration could induce all employers to pay more and cause landlords to give more liberal terms to those left behind. ${ }^{125}$ Members of the Dublin Statistical Society co-founded by Whately and from 1862 renamed the Statistical and Social Inquiry Society of Ireland (S.S.I.S.I.) ${ }^{126}$ - were similarly circumspect. James Lawson and Denis Caulfield Heron, erstwhile professors of political economy at Trinity College Dublin and Queen's College Galway respectively, spoke against emigration that was the result of 'bad laws at home', or 'the indication and result of a vicious state of things at home'. However, each found that 'voluntary emigration' had a place and, in Heron's words, would 'continue until wages are equal in Connemara and Chicago. ${ }^{127}$ Neither man believed that there should be intervention to prevent such migration.

By the time departures had begun to rise again due to the repeated harvest failures in the early 1860 s, the pro-emigration tone of the 'Dublin School' (perhaps 'anti-anti-emigration' is more accurate) was on the face of it more assertive. ${ }^{128}$ John Kells Ingram argued that emigration was 'a perfectly natural consequence of economic laws acting under the new conditions of human societies', and agreed with W. Neilson Hancock, former holder of the Chairs of Political Economy at Trinity and Queen's College, Belfast, that it was 'idle to deplore emigration as necessarily a calamity.' ${ }^{129}$ Another member affirmed that continued emigration was 'the only prompt remedy for the poverty of small farmers and working men which lies within our reach. ${ }^{130}$ There were dissenters from this line of thought, ranging from John Stuart Mill, who regarded the ongoing exodus as England's 'loss and disgrace', to those such as the Saunder's Newsletter correspondent who felt that emigration had 'reduced the number of the labouring population below the requirements of the country' to Heron, who had come to believe that 'in men is the wealth of a state. ${ }^{131}$ However, the prevailing, laissez-faire view of emigration put forward by Irish economists could be seen to tie in with the views and the interests of the landed class, as demonstrated by an interjection by one of its more progressive members in The Times in 1866. In December of that year, 
Lord Dufferin, an Ulster landowner and Whig politician, mounted a defence of his fellow landlords against the charge of exercising 'an exterminating policy', later expanding the argument into a pamphlet which drew heavily on statistical evidence provided by Hancock and others. ${ }^{132}$ A version edited for mass consumption by an approving committee of peers emphasised the central point: 'Emigration may be occasioned by a calamity; it may be followed by disastrous consequences; but it is in itself a curative process. ${ }^{133}$

If Irish landlords thereby hoped to persuade their critics, including clerical ones, that they were not responsible for the exodus, they were destined to fail. By restating a broader economic case in favour of emigration, one that was even then losing its near-consensus status among political economists, they merely seemed to confirm the 'cruel theory' that Archbishop MacHale had earlier condemned: that where there was suffering, 'the rich landlord is to be entirely exempt, and the poor tenant [is] to bear the whole weight of adverse and tempestuous seasons. ${ }^{134}$ Any improvement in the economy wrought thus far by emigration, claimed the bishops, had come by increasing the land given over to cattle and sheep at the expense of people. ${ }^{135}$ As the Bishop of Galway complained in an 1867 pastoral, emigrants were given 'the cold assurance of heartless economists that the country needed depletion and that they should be offered up as victims for the supposed general good of society.' ${ }^{136}$ The more moderate voice of David Moriarty, Bishop of Kerry, spelled out to Dufferin where he and his fellow landlords went awry:

Your Lordship and the Irish landlords must get rid of the notion that we have too large a population, and that emigration is a positive good. [...] It does great harm when landlords and especially noblemen connected with the government of the country speak of it with favour. It is always interpreted as indicating a hatred of the Celtic race, a desire to get rid of them. ${ }^{137}$

Church of Ireland clergy reacted to Dufferin's intervention somewhat differently, as connections with the Dublin School suggested they might. Whately aside, a paper by Thomas Jordan, a Dublinbased curate, to the Statistical Society in 1856 had indicated that an acceptance of the economic desirability of emigration still came readily even to many lower-ranked Protestant clergy. ${ }^{138}$ Sure enough, Michael Keating re-emerged, warmly greeting Dufferin's 'excellent' Times article and sending him papers from his Limerick Emigrants' 
Friend Society days. ${ }^{139}$ William Edwards, a Donegal rector, also wrote to Dufferin, pressing the point that advances in shipping and the consequent cheapness of travel could be held responsible for any recent upsurge in departures. In that sense, they were a natural phenomenon, further encouraged by higher wages in America. He added, in a swipe at Catholic anti-emigration rhetoric, that since so many others had gone to Britain, it was apparent that 'a very large number of those whom agitators describe as being driven from the country by the tyranny of England, have in fact been driven by her into a closer contact with herself'. ${ }^{140}$ The Anglican Bishop of Ossory appeared more understanding of Catholic feelings that emigration was 'the most grievous of all calamities', but was evidently moderating his stance in an attempt to protect his own bailiwick. Catholic clergy, he asserted, 'know very well that of all the many thousands who leave the Irish shores year after year, there is not even a single one driven from his country by the Established church'. The Bishop insisted that priests should concentrate on bringing about a change in landlordtenant relations if they wished to stop emigration; a campaign for disestablishment would be a distraction. ${ }^{141}$

Presbyterian churchmen regarded emigration with a little more caution. One periodical had joined in the early belief that the lessening of the population since the Famine had led the country 'to a height of prosperity unprecedented in all its former history', and William Hancock alluded to 'the favour with which emigration is still viewed amongst Presbyterians' when he drew attention to a plan for Presbyterian settlement in New Zealand being promoted by clergy in several congregations in $1863 .{ }^{142}$ However, it is likely that Hancock was reading too much into what may well have been a one-off initiative to safeguard the religious and moral welfare of those for whom emigration was the only alternative to the workhouse, and in that sense, like similar, crossdenominational attempts to relieve unemployed weavers, was not a whole-hearted endorsement of emigration as a permanent means of relief. ${ }^{143}$ Certainly, those Presbyterian ministers who attended Tenant Right meetings - and in Ulster they were many - offered a similar critique to their Catholic counterparts. ${ }^{144}$ Indeed, on the eve of the passage of Gladstone's first Land Act, a General Assembly delegate expressed a hope that this 'full satisfaction' would remove any further need for emigration from Presbyterian congregations. ${ }^{145}$

The final efflorescence of sustained controversy over emigration, and perhaps the most intensive, came once again during a period 
of economic depression. A run of poor harvests in 1877-79 created particular distress along the agriculturally unmodernised western seaboard. This led to an increased outflow of emigrants, but also catalysed aggrieved tenant farmers and their political allies into a full-scale 'war' for land reform. ${ }^{146}$ Into this maelstrom was pitched a renewed enthusiasm for organised migration, encouraged by parallel developments in Britain, and driven in Ireland primarily by the efforts of two philanthropists, Belfast educationalist Vere Foster and James Hack Tuke, a Yorkshire Quaker. ${ }^{147}$ While Foster acted as personal benefactor to thousands of single Irishwomen, expanding activities he had first begun during the Famine, Tuke ran the first scheme since Robert Wilmot Horton's in the 1820s to extract significant Treasury funding, which was used to migrate whole families from Connacht to North America. To that extent, Tuke, despite a previous aversion to emigration that had been praised by no less than the rebel Fenian priest Patrick Lavelle, proved the more strategically minded of the two. ${ }^{148}$ Like previous emigration advocates, Tuke hoped his method would free up small, uneconomical holdings and bring about land consolidation as a precursor to permanent recovery. ${ }^{149}$

Both schemes attracted clerical attention. Indeed, Foster's demanded it, since he issued passage money vouchers to each of the more than twenty thousand women he aided only on application by a local teacher or religious minister ${ }^{150}$ In the early 1880 s, upwards of a thousand clergymen of all denominations co-operated, though some more enthusiastically than others. ${ }^{151}$ The Church of Ireland clergymen among them, on the whole appeared to regard emigration as 'the only real remedy for our condition', with one Roscommon vicar anxious to see state colonisation. 'I advocated emigration after the Famine of 1846 to 52', he told Foster, 'and if my advice had then been taken [and] ships put on the water for free emigration instead of Poor Houses built the country would be better off this day. ${ }^{152}$ Catholic clergy, if Foster's printed publicity for the scheme was to be taken at face value, held similar pro-emigration opinions. ${ }^{153}$ However, he quoted from their letters rather selectively, leaving out any statements against emigration, and most priests seemed more concerned about the welfare of individual emigrants than any broader notions of lessening an excessive Irish population in preparation for economic recovery. ${ }^{154}$ For evident geographic reasons, few Presbyterian clergymen corresponded with Foster, but contemporary periodicals confirm that the notion of a surplus population found supporters in some corners, and 
that, where it did not, there remained a sense that those for whom there was nothing at home should consider leaving. ${ }^{155}$

While Tuke's early charitable efforts met with a similarly benign clerical reception, including the praise of some Presbyterian ministers, it was clear that as soon as government finance was provided in the form of a $£ 100,000$ grant in mid-1882, the Catholic Church turned decisively against him. ${ }^{156}$ With his close personal connection to the Chief Secretary, W. E. Forster, and his committee of English Liberal MPs and Irish gentlemen, Tuke suddenly appeared to personify the worst spectres of nationalist rhetoric. He partly confirmed one priest's typical claim at a Land League meeting that Ireland was now home to 'fat cattle and famishing Christians [...] emigration schemes and cattle shows', and by removing entire families he was open to the popular charge of 'emigration by wholesale', and of depopulation masquerading as philanthropy. ${ }^{157}$ Clergy and bishops of the west therefore united in railing against the Tuke committee, ${ }^{158}$ and in July 1883 a joint pastoral was issued by the entire Catholic hierarchy, condemning the state-aided emigration as 'unwise and impolitic' and tending 'only to promote disaffection amongst the Irish race at home and abroad. ${ }^{159}$ To the new Archbishop of Tuam, John McEvilly 'the determination of the Government to transport our people to Canada' was 'the most terrible curse. ${ }^{160}$

A further twist came in October when a 'confidential circular' prepared by members of Tuke's committee, and proposing to put state-aided emigration on a more permanent footing, was leaked to the press. It was duly described as 'the production of hell itself', and attracted the opprobrium of western deaneries and of McEvilly. ${ }^{161}$ So great was the outcry that Dublin Castle officials felt the need to explain themselves in an open letter to McEvilly, assuring him that the proposals had not even been seen by them and did not reflect the government's true intentions. ${ }^{162}$ Although grudgingly accepted by all concerned, a suspicion lingered that the circular had provided an accurate 'glimpse into the mind of government. ${ }^{163}$ Nevertheless, the embarrassment of this incident may have helped persuade Parliament to split the next grant to Tuke's committee and in so doing may have heralded the ultimate undoing of the emigration scheme. ${ }^{164}$ In 1883 , $£ 50,000$ was given to Tuke's efforts, and another $£ 50,000$ towards what had long been the Catholic spokesmen's favoured alternative to emigration: home colonisation. ${ }^{165}$

This incarnation of 'migration', as distinct from emigration, derived 
chiefly from a suggestion of the agriculturalist Thomas Baldwin before the Richmond Commission in 1881, and found its strongest support in the Catholic Church. Baldwin initially believed that his plan for internal migration from the 'congested districts' of the west to other parts of Ireland, supplemented by a measure of emigration, would be accepted by the bishops 'in the interests of humanity'. ${ }^{166}$ However, the evidence of the Bishop of Clonfert before the same body contradicted him. Patrick Duggan insisted that 'no matter how well carried out' he would never support a scheme involving emigration. 'I have other reasons besides economic ones', he explained in a telling phrase. ${ }^{167}$ Several other bishops communicated the same point to Baldwin once his plans were published. Internal migration alone could relieve the region, they felt, and there would be no need for 'deportation' on top of that. ${ }^{168}$ MPs had therefore consulted several western bishops on migration before granting funds, and following their allocation and the formation of the Land Purchase Company which was to carry out the project, bishops and clergy entered into its promotion with great zeal. ${ }^{169}$ Mass public meetings were arranged and chaired by prelates, while deaneries issued supportive statements and several clergymen bought shares in the company, including Bishop Michael Logue of Raphoe who took 1,500. ${ }^{170}$ All seemed to agree with the hastily clarified remark of Baldwin, who was appointed director of the company, that 'if emigration was a remedy for the ills of Ireland they would have been cured long since. ${ }^{171}$ Finally, it appeared, a panacea for poverty and distress that would keep people at home was being applied. After a short burst of activity, however, the migration project came to nothing. Like the Protestant Colonisation Society of fifty years earlier, the migration company bought up land but that was found to be unsuitable and was publicly criticised by Michael Davitt as 'no bargain.' ${ }^{172}$ No families were settled and by the end of 1884 , with no alternative land having been found, all impetus seemed to have been lost. ${ }^{173}$ It should be noted that the Congested Districts Board, with which both Catholic and Protestant clergy closely co-operated, undertook migration and wasteland reclamation in the 1890s, but not without considerable difficulty and expense. ${ }^{174}$

Through these successive phases of the heaviest emigration from Ireland we can trace significant changes in clerical perceptions of its usefulness and desirability. A majority of all clergy in the 1830s believed that emigration could form part of the solution to Ireland's problems and were open to its encouragement, direction or organi- 
sation, whether by the state or by private bodies. Before 1845 , only a coterie of rather extreme Protestant clergy appeared to offer any sustained criticism of emigration as a means of relief, upbraiding landlords and government for the negligence and lack of fellow feeling that allowed thousands of their brethren to be expatriated. After the Famine, whatever echoes of that sentiment remained were all but drowned out by a strikingly similar, but much greater outpouring of Catholic anger. Any trust of government, of landlords, or of the brands of political economy to which they subscribed, had been comprehensively shattered by their woefully inadequate and doctrinaire responses to the Famine. Emigration was now 'depopulation', 'deportation' or 'extermination'. It had become a problem requiring a solution, rather than a solution to a problem.

\section{Notes}

1 Miller, Emigrants and Exiles, p. 345; Fitzpatrick, Irish Emigration, p. 30.

2 Fitzpatrick, Irish Emigration, p. 17.

3 Robert Southey, Essays Moral and Political (2 vols, London, 1832), ii, p. 275; N. H. Carter, Letters from Europe, comprising the Journal of a Tour through Ireland, England, Scotland, France, Italy, and Switzerland, in the years 1825, '26, and '27 (2 vols, New York, 1827), i, p. 213.

4 Mokyr, Why Ireland Starved, pp. 38-51; Peter Solar, 'Why Ireland starved: a critical review of the econometric results' in I.E.S.H., xi (1984), 110; Liam Kennedy, 'Studies in Irish econometric history' in I.H.S. xxiii: 91 (May 1983), 201-5.

5 Those who did reject the centrality of the overpopulation thesis included J. R. Elmore and George Poulett Scrope. J. R. Elmore, Letters to the Right Hon. the Earl of Darnley, on the State of Ireland, in Advocacy of Free Trade and other Measures of Practical Improvement, more especially calculated to supersede the Necessity of Emigration (London, 1828); [G. Poulett Scrope], 'The political economists' in Quarterly Review, xliv (Jan. 1831), 1-52.

6 Boyd Hilton, A Mad, Bad, and Dangerous People?: England 1783-1846 (Oxford, 2006), pp. 335-6.

7 On pre-Famine food shortages, see Timothy P. O’Neill, 'Poverty in Ireland, 1815-45' in Folk Life, xi (1974), 22-33; Timothy P. O'Neill, 'Minor famines and relief in County Galway, 1815-1925' in Gerard Moran (ed.), Galway History \& Society: Interdisciplinary Essays on the History of an Irish County (Dublin, 1996), pp. 445-60.

8 William Parker, An Essay on the Employment which Bridges, Roads, and other Public Works may afford the Labouring Classes (Cork, 1819); William Allen, Colonies at Home; or, the Means for Rendering the Industrious 
Labourer Independent of Parish Relief; and for Providing the Poor Population of Ireland, by the Cultivation of the Soil (Dublin, 1827); R. D. Collison Black, Economic Thought and the Irish Question 1817-1870 (Cambridge, 1960), pp. 86-8.

9 Donald Winch, 'Introduction' in T. R. Malthus, An Essay on the Principle of Population; or A View of its Past and Present Effects on Human Happiness; with an Introduction into our Prospects Respecting the Future Removal or Mitigation of the Evils which it Occasions, ed. Donald Winch (Cambridge, 1992), p. xiv.

10 Robert Torrens, Paper on the Means of Reducing the Poors Rates and of Affording Effectual and Permanent Relief to the Labouring Classes (London, 1817), pp. 527-8.

11 Peter Gray, The Making of the Irish Poor Law, 1815-43 (Manchester, 2007), p. 48.

12 Griffin, The People with No Name, p. 65; R. J. Dickson, Ulster Emigration to Colonial America, 1718-1775 (Belfast, 1966), p. 182.

13 Dickson, Ulster Emigration, p. 183.

14 T. R. Malthus, An Essay on the Principle of Population; or, A View of its Past and Present Effects on Human Happiness (2 vols, London, 1809), ii, 134; [J. R. McCulloch], 'Ireland', Edinburgh Review, xxxvii:73 (June 1822), 108.

15 See Malthus to R. J. Wilmot Horton, 21 Feb. 1823 in R. N. Ghosh, 'Malthus on emigration and colonisation: Letters to Wilmot-Horton' in Economica, xxx:117 (Feb. 1963), 48.

16 Malthus to Horton, 23 Aug. 1830, Ibid., 55.

17 An estimate of the sum required for facilitating emigration from the south of Ireland for the year 1825, p. 5, H.L. 1825 (131), xviii, 361 [henceforth cited as An estimate for emigration for 1825]; Adams, Ireland and Irish Emigration, pp. 146-7.

18 Edward Gibbon Wakefield (ed.), A View of the Art of Colonisation with Present Reference to the British Empire; Letters between a Statesman and a Colonist (London, 1849).

19 Oliver Goldsmith, The Vicar of Wakefield (London, 1766); Scottish clerical opinions on emigration, for example, have been explored in Allan W. MacColl, Land, Faith and the Crofting Community Christianity and Social Criticism in the Highlands of Scotland, 1843-1893 (Edinburgh, 2006), pp. 204-9; David Paton, The Clergy and the Clearances. The Church and the Highland crisis 1790-1850 (Edinburgh, 2006).

20 Dickson, Ulster Emigration, p. 5, p. 183; Griffin, The People with No Name, p. 79; for similar sentiment in Scotland see Eric Richards, A History of the Highland Clearances Vol. 2. Emigration, Protest, Reasons (London, 1985), p. 202.

21 Doyle, Ireland, Irishmen and Revolutionary America, p. 54; E. R. R. Green, 'The strange humors that drove the Scotch-Irish to America, 1729' in The 
William and Mary Quarterly, xii:1 (Jan. 1955), 14.

22 An estimate for emigration for 1825, p. 3, H.L. 1825 (131), xviii, 359; Report from the select committee on the state of Ireland: 1825 p. 22, H.C. 1825 (129), viii, 22. Hereafter, Report on the state of Ireland.

23 Boyd Hilton, The Age of Atonement: The Influence of Evangelicalism on Social and Economic Thought, 1785-1865 (Oxford, 1986), p. 36.

24 [Richard Whately], 'Emigration to Canada', Quarterly Review, xxiii (July, 1820), 387-8.

25 Report from the select committee on emigration from the United Kingdom, pp. 142-5, H.C. 1826 (404), iv, 142-5.

26 Anon, 'Correspondence', in Christian Examiner and Church of Ireland magazine, vi:35 (May 1828), 330-1.

27 Black, Economic Thought, p. 87; Horatio Townsend, Statistical Survey of the County of Cork, with Observations on the Means of Improvement; Drawn up for the Consideration, and by Direction of the Dublin Society (Dublin, 1810), pp. 81-2.

28 Quoted in Parker, Essay on the Labouring Classes, pp. 22-3.

29 M. I. Keating, A Letter to Wilmot Horton, esq. MP, on Emigration from Ireland (Limerick, c. 1826/27), p. 5.

30 Ibid., pp. 6-8.

31 First report of evidence from the select committee on the state of the poor in Ireland, p. 154, H.C. 1830 (589), vii, 324.

32 Second report from the select committee on the state of the poor in Ireland, p. 323, H.C. 1830 (654), vii, 499 [henceforth cited as Second report on state of poor].

33 Third report from the select committee on emigration from the United Kingdom, 1827, p. 274, H.C. (550), v, 496.

34 Richard Ryan, Practical Remedies for the Practical Evils of Ireland (Dublin, 1828), p. 18.

35 P.R.O.N.I., Beresford papers, D664/A/229, letter from Richard Ryan to Archbishop John George Beresford, 15 May 1831.

36 A. R. C. (A clergyman of the established church), Ireland and the Remedy for her Evils (Dublin, 1830), p. 26.

37 J. B. McCrea, Protestant Poor a Conservative Element of Society; being a Sermon Preached in Ebenezer Church, Dublin for the Protestant Colonisation Society of Ireland (Dublin, [1834?]), pp. 28-9; See Hilton, Age of Atonement, pp. 49-50 for similar clerical distrust of political economy, and for Whately's importance in defending against this distrust, see Salim Rashid, 'Richard Whately and Christian political economy at Oxford and Dublin' in Journal of the History of Ideas, xxxviii:1 (Jan.-Mar. 1977), 150-1.

38 The founding document of the society, [Anon., The Protestant Colonisation Society of Ireland At a meeting of the General Committee held at the Society's Apartments, no. 15, Dame-street, on Friday, the 18th day of 
December, 1829 (Dublin, 1829)] cited the pamphlet A Member of the Highland Society of Scotland [Elias Cathcart?], An account of the Poor Colonies and Agricultural Work-houses of the Benevolent Society of Holland (Edinburgh, 1828); Transactions of the Protestant Colonisation Society of Ireland, reported at a Public Meeting of Subscribers, in the Dublin Institution, on May 24, 1832 (Dublin, 1832), p. 12.

39 Belfast News Letter, 22 Sept. 1829; R. M. Sibbett, Orangeism in Ireland and throughout the Empire (2 vols, Belfast, 1915), ii, p. 349; Second report from the select committee appointed to inquire into the nature, character, extent and tendency of Orange lodges, associations or societies in Ireland with the minutes of evidence and appendix, p. 249, H.C. 1835 (475-476), xv, 253.

40 P.R.O.N.I., Beresford papers, D642/1/221B, letter from Barre Beresford to J.G. Beresford, 17 Aug 1829; P.R.O.N.I., Beresford papers, T2772/2/4, letter from John George Beresford to Archbishop Howley, 4 Feb 1830.

$41 \mathrm{~J}$. E. Bicheno, Ireland and its Economy: Being the Result of Observations made in a Tour through the Country in the Autumn of 1829 (London, 1830), p. 273.

42 Transactions of the Protestant Colonisation Society, 1832, pp. 6-7, 32.

43 M. H. Seymour, The Speech of Rev. Mr Seymour at the Sligo Protestant Dinner (Sligo[?], 1830[?]), p. 11; Belfast Commercial Chronicle, 7 May 1832. 44 Harriet Martineau, Illustrations of Political Economy: Ireland, A tale (London, 1832), p. 129.

45 Report on the state of Ireland, pp. 428-9, H.C. 1825 (129), viii, 442-3.

46 J. K. L., Letters on the State of Ireland; Addressed by J.K.L. to a Friend in England (Dublin, 1825), p. 115.

47 W. J. Fitzpatrick, The Life, Times, and Correspondence of the Right Reverend Dr Doyle, Bishop of Kildare and Leighlin (Dublin, 1890), p. 44.

48 Second report on state of poor, p. 407, H.C. 1830 (654), vii, 583.

49 Gray, Irish Poor Law, pp. 126-7.

50 Poor inquiry (Ireland). Appendix (C) - Parts I. and II. Part I. Reports on the state of the poor, and on the charitable institutions in some of the principal towns; with supplement containing answers to queries. Part II. Report on the city of Dublin and supplement containing answers to queries; with addenda to appendix (A.), and communications, 2 [35-42], H.C. 1836, xxxiv, 36 [henceforth cited as Poor inquiry].

51 Ibid., 142 [35], H.C. 1836, xxxiv, 254.

52 Ibid., 33e [35], H.C. 1836, xxxiv, 592.

53 Ibid., 120 [35], H.C. 1836, xxxiv, 546; 329 [35], H.C. 1836, xxxiv, 755; 344 [35], H.C. 1836, xxxiv, 771; 313 [35], H.C. 1836, xxxiv, 740.

54 Ibid., 141 [35], H.C. 1836, xxxiv, 143.

55 Ibid., 179 [35], H.C. 1836, xxxiv, 181; 40c [35], H.C. 1836, xxxiv, 532; 134 [35], H.C. 1836, xxxiv, 136.

56 Ibid., 133 [35], H.C. 1836, xxxiv, 591.

57 Ibid., 182 [35], H.C. 1836, xxxiv, 608. 
58 Ibid., 184 [35], H.C. 1836, xxxiv, 610; 205 [35], H.C. 1836, xxxiv, 631.

59 Ibid., 379 [35], H.C. 1836, xxxiv, 805.

60 Ibid., 94 [35], H.C. 1836, xxxiv, 520; 117 [35], H.C. 1836, xxxiv, 543.

61 Ibid., 218 [35], H.C. 1836, xxxiv, 644.

62 Fitzpatrick, 'Emigration, 1801-70', 581.

63 Mokyr, Why Ireland Starved, pp. 243-4; Johnson, 'The context of migration', 266.

64 Poor inquiry, 322 [35], H.C. 1836, xxxiv, 748; 314 [35], H.C. 1836, xxxiv, $740 ; 362$ [35], H.C. 1836, xxxiv, 478.

65 Ibid., 222 [35], H.C. 1836, xxxiv, 648.

66 Ibid., 136 [35], H.C. 1836, xxxiv, 562.

67 Ibid., 137 [35], H.C. 1836, xxxiv, 563.

68 Ibid., 134 [35], H.C. 1836, xxxiv, 560.

69 Dickson, Ulster Emigration, pp. 32-47; M. R. Beames, 'Rural conflict in pre-famine Ireland: peasant assassination in Tipperary 1837-1847' in Past and Present, 81 (Nov. 1978), 85.

70 George Cornwall Lewis, On Local Disturbances in Ireland and on the Irish Church Question (London, 1836), p. 458.

71 On Protestant perceptions of agrarian violence, see Elliott, Irish Migrants in the Canadas, p. 35; Liam Kennedy, Kerby A. Miller and Brian Gurrin, 'Minorities, majorities and demographic power: The Protestant and Catholic communities of Tipperary since 1660' in Sean Farrell and Michael De Nie (eds), Power and Popular Culture in Modern Ireland (Dublin, 2010), pp. 82-5. For an examination of the motives of one agrarian movement, see James S. Donnelly, Jr, Captain Rock: The Irish Agrarian Rebellion of 1821-24 (London, 2008), passim.

72 Poor inquiry, 80 [35], H.C. 1836, xxxiv, 506.

73 Ibid., 288 [35], H.C. 1836, xxxiv, 714.

74 Ibid., 153 [35], H.C. 1836, xxxiv, 579; 355 [35], H.C. 1836, xxxiv, 781; 134 [35], H.C. 1836, xxxiv, 560.

75 The sentiment was again evident in 1840 at a Fermanagh Conservative Festival, and in 1841 in a similar organisation, the Irish Protestant Tenantry Society. The Tablet, 5 Dec. 1840; The Tablet, 16 Jan. 1841; Poor inquiry, 222 [35], H.C. 1836, xxxiv, 648. On previous Palatine emigration, see Taggart, Irish in World Methodism, pp. 37-8.

76 Poor inquiry, 283 [35], H.C. 1836, xxxiv, 709; 234 [35], H.C. 1836, xxxiv, 660; 181 [35], H.C. 1836, xxxiv, 607.

77 Ibid., 173 [35], H.C. 1836, xxxiv, 599.

78 Keenan, Catholic Church, p. 199.

79 Poor inquiry, 321 [35], H.C. 1836, xxxiv, 747.

80 Ibid., 356 [35], H.C. 1836, xxxiv, 782.

81 Third report of the commissioners for inquiring into the condition of the poorer classes in Ireland, 27 [43], H.C. 1836, xxx, 27. 
82 Fergus D'arcy, 'Religion, radicalism and rebellion in nineteenth-century Ireland: The case of Thaddeus O'Malley' in Judith Devlin and Ronan Fanning (eds), Religion and Rebellion. Historical studies XX. Papers read before the 22nd Irish Conference of Historians, held at University College Dublin, 18-22 May 1995 (Dublin, 1997), pp. 97-105; T[haddeus] O'Malley, An Idea of a Poor Law for Ireland (London, 1837), pp. 78-9; Report from the select committee of the House of Lords on the laws relating to the relief of the destitute poor, and into the operation of medical charities in Ireland; together with the minutes of evidence taken before said committee, p. 833, H.L. 1846 (694-694-II-694-III), xi, 869.

83 A Presbyterian example: Henry Montgomery gave a charity sermon on behalf of an emigration society set up to aid 80 unemployed weavers B.N.L., 26 May 1829; Report of the select committee of the House of Lords on colonisation from Ireland; together with the minutes of evidence, p. 133, H.L. 1847 (737-737-II), vi, 107 [Henceforth Report on colonisation].

84 Smith O'Brien was a founder member of Wakefield's National Colonisation Society. Richard Davis, Revolutionary Imperialist William Smith O’Brien 1803-1864 (Dublin, 1998), pp. 43-4.

85 Keating, who had previously corresponded with Wilmot Horton, joined Archdeacon Maunsell and Fr James Fitzgerald in taking committee positions. Limerick Herald, 15 Jan. 1833; Publications issued by the society include Anon., Information published by His Majesty's Commissioners for Emigration, respecting the British Colonies in North America (Limerick, c. 1833), and Anon., Sketch of the Province of New Brunswick, published for the Use of Emigrants (Limerick, n.d.); Keating, Letter to Wilmot Horton, p. 14; M. I. Keating, Emigration, To the Right Honourable Lord Morpeth, MP (Limerick, 1836).

86 O'Connell criticised 'the romance of the Emigration Report' [Horton's of 1827] but later served on a select committee which approved Wakefield's ideas, and urged the government to implement them in a speech in 1837; O’Connell to Pierce Mahony, 17 [and 19] Sept. 1828, in Maurice R. O'Connell, The Correspondence of Daniel O'Connell (8 vols, Dublin, 1972-80), iii, pp. 406-10; Report from the select committee on the disposal of lands in the British colonies; together with the minutes of evidence, and appendix, p. 1, H.C. 1836 (512), xi, 499; Speech to House of Commons, 28 Apr. 1837, cited in M. F. Cusack, The Speeches and Public Letters of the Liberator (Dublin, 1875), p. 502.

87 The Tablet, 1 Apr. 1843. Several Catholic bishops and clergy also took places on the Society's committees of management. The Nation, 25 Mar. 1843.

88 Anon., Prospectus, North American Colonial Association of Ireland (Dublin, 1834), p. 3.

89 H. T. Manning, 'E. G. Wakefield and the Beauharnois Canal', in 
Canadian Historical Review, xlviii (1967), 1-25; Philip Temple, A Sort of Conscience: the Wakefields (Auckland, 2002), pp. 324-48.

90 David J. Moss, 'Wakefield, Edward Gibbon (1796-1862)' in H. C. G. Matthew and Brian Harrison (eds), Oxford Dictionary of National Biography (Oxford, 2004).

91 D.D.A., Murray papers, 31/7/14, letter from John Moore, Secretary, N.A.C.A.I. to Murray, 10 June 1839; 32/2/77, letter from John Dewar, Secretary, N.A.C.A.I. to Murray, 5 Mar. 1846.

92 Thomas Rolph, Emigration and Colonisation; Embodying the Results of a Mission to Great Britain and Ireland during the years 1839, 1840, 1841, and 1842; including a Correspondence with many Distinguished Noblemen and Gentlemen, several of the Governors of Canada, etc.; Descriptive Accounts of Various Parts of the British American Provinces; with Observations, Statistical, Political, etc. (London, 1844), p. 15.

93 Evidence taken before Her Majesty's commissioners of inquiry into the state of the law and practice in respect to the occupation of land in Ireland. Part ii, 798 [616], H.C. 1845, xx, 792. (Henceforth cited as Devon Commission).

94 Devon Commission Part iii, 171 [657], H.C. 1845, xxi, 165.

95 See pages $\left.93-8 .{ }^{*}\right]$

96 Report on colonisation, p. 183, H.L. 1847 (737-737-II), vi, 199; pp. 202-16, H.L. 1847 (737-737-II), vi, 771-87.

97 Peter Gray, "Shovelling out your paupers': The British state and Irish famine migration 1846-50' in Patterns of Prejudice, xxxiii:4 (1999), 65.

98 Freeman's Journal, 14 Apr. 1847, reprinted in The Nation, 17 Apr. 1847.

99 The Tablet, 1 May, 1847; See The Tablet, 15 May, 1847 for a condemnatory resolution from the clergy of Westport and F.., 21 Apr. 1847 for a critique by Thomas Feeny, Bishop of Killala. There was also Protestant disquiet about the potential establishment of 'a Popish and rebellious dependency'. B.N.L., 5 Jan. 1849.

100 Report on colonisation, p. 188, H.L. 1847 (737-737-II), vi, 204.

101 N.L.I., Monteagle papers, Ms. 13,400/II/36, letter from Godley to Spring-Rice, 8 Apr. 1847.

102 James S. Donnelly, Jr, 'Mass evictions and the Great Famine' in Cathal Póirtéir (ed.), The Great Irish Famine (Dublin, 1995), p. 156.

103 N.L.I., Prior-Wandesforde papers, Ms 35,533, letter from Fr Salmon to T. M. Ray, 18 Apr. 1844; Second report from the select committee of the House of Lords on colonisation from Ireland; together with the further minutes of evidence. Session 1848. p. 275, H.L. 1847-48 (593), xvii, 283; Flannan P. Enright, 'Pre-Famine reform and emigration on the Wyndham estate in Clare' in The Other Clare, viii (Apr. 1984), 33-9.

104 Tyler Anbinder, 'Lord Palmerston and the Irish Famine emigration' in The Historical Journal, xliv:2 (June 2001), 57.

105 Gerard Lyne, The Lansdowne Estate in Kerry under the Agency of William 
Steuart Trench 1849-72 (Dublin, 2001), p. 77.

106 The Times, 11 Dec. 1847; Roscommon Journal, 27 Mar. 1847.

107 F.J., 18 Oct. 1850, 9 July 1851. The Nation, 14 Feb. 1852.

108 The Tablet, 29 Apr. 1848.

109 Padraig Vesey, The Murder of Major Mahon, Strokestown, Co. Roscommon, 1847 (Dublin, 2008), pp. 44-6; Patrick J. Duffy, 'Estate emigration schemes in mid-nineteenth century Ireland' in Patrick J. Duffy (ed.), To and from Ireland: Planned Migration Schemes c. 1600-2000 (Dublin, 2004), p. 103; L. O'Mearáin, 'Estate agents in Farney: Trench and Mitchell' in Clogher Record, x (1981), 405; M. F. Cusack, The Case of Ireland Stated: A Plea for my People and my Race (Dublin, 1880), p. 340. For Scottish comparisons on the memory of clearances, see Richards, Highland Clearances, passim; Laurence Gouriévidis, The Dynamics of Heritage: History, Memory and the Highland Clearances (Farnham, 2010).

110 Fitzpatrick, Irish Emigration, p. 20.

111 N.L.I., Monteagle papers, Ms. 13,400/II/33, letter from Whately to Spring Rice, 30 Mar. 1847.

112 A resident rector in the province of Leinster, Some Considerations suggested by the Loss of the Potato as a Staple Food in Ireland; and its Consequences as affecting the Moral and Domestic Position of the Peasantry addressed to Corry Connellan, esq. Private Sec. to His Excellency the Earl of Bessborough (Dublin, 1846), pp. 19-20.

113 Morning Chronicle, 20 Sept. 1847; William Pulteney Alison, Observations on the Famine of 1846-7, in the Highlands of Scotland and in Ireland as Illustrating the Connection of the Principle of Population with the Management of the Poor (London, 1847), p. 68.

114 William Prior Moore, The Case of Ireland, and Remedies suggested for the Amelioration of the Condition of her People contained in Two Letters to the Rt. Hon. Henry Labouchere, Chief Secretary of Ireland (Dublin, 1847), pp. 21-2; An Ulster clergyman, Moral and Religious Effect of Emigration (Dublin, 1850), pp. 3-4; P.R.O.N.I., Beresford papers, T2772/1/11/141, letter from Anon. to Beresford, 8 June 1849.

115 S. J. Connolly, 'Religion, work-discipline and economic attitudes: The case of Ireland' in T. M. Devine and David Dickson (eds), Ireland and Scotland 1600-1850: Parallels and Contrasts in Economic and Social Development (Edinburgh, 1983), p. 236.

116 Weekly Telegraph, 27 Sept. 1855; T. D. McGee, A Life of the Rt. Rev. Edward Maginn, Coadjutor Bishop of Derry: With Selections from his Correspondence (New York, 1857), p. 102.

117 Anon., 'Irish wastelands' in Dublin Review, xxxix:78 (Dec. 1855), 292-3; The Nation, 5 Dec. 1846.

118 B.N.L., 31 Jan. 1859; W. E. Vaughan, Sin, Sheep and Scotsmen John George Adair and the Derryveagh Evictions, 1861 (Belfast, 1983). 
119 U.N.D.A., Brownson papers, I-3-k-A.L.S.-4pp.-8vo.-\{15\}, letter from R. A. Bakewell to Orestes Brownson, 7 Jan. 1853.

120 D. W. Cahill, First Letter of Dr Cahill to the Roman Catholics of Ireland (Dublin, 1851), p. 5; W.T., 26 Feb. 1853.

121 W.T., 5 Dec. 1863.

122 D.D.A., Cullen papers, 340/8/51, letter from Archdeacon James Redmond to Cullen, 12 Sept. 1863.

123 I.C.R.A., Kirby papers, KIR/1863/101, letter from Archbishop Leahy to Kirby, 27 Mar. 1863; Ibid., KIR/1865/53, letter from John McEvilly to Dr Kirby, 10 Mar. 1865; Norman, Catholic Church, pp. 135-89; Larkin, Consolidation, pp. 273-340.

124 Although several noblemen were members of the Protestant Colonisation Society, at least one of its pamphlets had criticised the 'cupidity' of 'rapacious' Irish landlords. McCrea, Protestant Poor a Conservative Element of Society, pp. 21-2.

125 John Locke, Ireland's Recovery; or, Excessive Emigration and its Reparative Agencies in Ireland, an Essay, with Appendix, containing Useful Information, and Numerous Statistical Tables, Illustrating and Substantiating the Conclusions Deduced (London, 1854), pp. 2-3.

126 Mary E. Daly, The Spirit of Earnest Inquiry: The Statistical and Social Inquiry Society of Ireland 1847-1997 (Dublin, 1997), p. 12.

127 James A. Lawson, The Over-population Fallacy Considered: A Paper read before the Dublin Statistical Society (Dublin, 1849), pp. 7-8; D. Caulfield Heron, Celtic Migrations: A Paper read before the Dublin Statistical Society on Monday, January 19, 1848 (Dublin, 1853), p. 11.

128 See Peter Gray, 'The making of mid-Victorian Ireland? Political economy and the memory of the Great Famine' in Peter Gray (ed.), Victoria's Ireland?: Irishness and Britishness, 1837-1901 (Dublin, 2004), pp. 161-6 for the longer term changes in the Dublin School's stance on land and emigration.

129 John Kells Ingram, Considerations on the State of Ireland: Being an Address delivered before the Statistical and Social Inquiry Society of Ireland, at the Opening of its Seventeenth Session on Wednesday, November 18, 1863 (Dublin, 1863), p. 6; W. Neilson Hancock, Report on the Supposed Progressive Decline of Irish Prosperity (Dublin, 1863), p. 14.

130 A member of the Statistical and Social Inquiry Society of Ireland [John Haslam], The Real Wants of the Irish People (Dublin, 1865), p. 38.

131 John Stuart Mill, Principles of Political Economy with some of their Applications to Social Philosophy (2 vols, London, 1865), i, p. 415; D. C. Heron, 'Ireland in 1864' in Journal of the Statistical and Social Inquiry Society of Ireland, iv:28 (Oct. 1864), 107; Henry Coulter, The West of Ireland: Its Existing Condition, and Prospects (Dublin, 1862), pp. 276-7.

132 The Times, 11 Dec. 1866; The Rt. Hon. Lord Dufferin, K.P., Irish Emigra- 
tion and the Tenure of Land in Ireland (London, 1867); P.R.O.N.I., Dufferin papers, D/1071/H/B/H/137/1, letter from W. Neilson Hancock to Dufferin, 4 Oct. 1866; Ibid., D/1071/H/B/ C/447/1, letter from R. S. Clokey to Dufferin, 12 Dec. 1866

133 Anon. (ed.), The Tenure of Land in Ireland Abridged from the Work of The Right Hon. Lord Dufferin, K.P on that Subject; with Additions and Alterations (Dublin, 1870), p. 16; P.R.O.N.I., Dufferin papers, D/1071/ H/B/H/G/496/1-3, letter from Lord Oranmore to Dufferin, 1867; See also Ibid., D/1071/H/B/H/G/387/1, letter from Peggy Greer to Dufferin, 17 Dec. 1866.

134 Letter from the Archbishop of Tuam to Lord Palmerston, Galway American, 25 Apr. 1863.

135 Preliminary report from Her Majesty's Commissioners on agriculture, 500, [C.2778], H.C. 1881, xv, 528. Henceforth cited as Richmond Commission.

136 Liam Bane, The Bishop in Politics: Loyal Friend, Bitter Foe, Life and Career of John McEvilly (Westport, 1993), p. 132.

137 P.R.O.N.I., Dufferin papers, D/1071/H/B/H/M, letter from David Moriarty to Dufferin, 23 Mar. 1868.

138 Thomas E. Jordan, 'Effects of emigration: can it be made a means of relieving distress?' in J.S.S.I.S.I., i:7 (Oct. 1856), 378-84.

139 P.R.O.N.I., Dufferin papers, D/1071/H/B/K/26/1, letter from Michael Keating to Dufferin, 10 Dec. 1866; Ibid., D/1071/H/B/K/26/2, letter from Keating to Dufferin, 18 Jan. 1867.

140 Ibid., D/1071/H/B/E/31/1, letter from W. Edwards to Dufferin, 11 Jan. 1867

141 James Thomas, The Church in Ireland; Our Duty in regard to its Defence: Being a Speech, delivered at a Meeting of the Clergy and Laity of the Diocese of Ossory, held at Kilkenny, on behalf of the Church Institution (London, 1866), pp. 21-2.

142 Anon., 'Ireland as it is' in Presbyterian Magazine, new series, i:2 (Feb. 1859), 25; Hancock, Report on the Supposed Progressive Decline, p. 17, pp. 85-6.

143 B.N.L., 23 Dec. 1862, 11 Mar. 1863, 21 May 1863.

144 Frank Thompson, The End of Liberal Ulster: Land Agitation and Land Reform, 1868-1886 (Belfast, 2001), pp. 128-9.

145 F.J., 18 Oct. 1850; B.N.L., 8 June 1870, 22 Jan. 1874.

146 Samuel Clark, Social Origins of the Irish Land War (Guildford, 1979), p. 245; B. L. Solow, The Land Question and the Irish Economy, 1870-1903 (London, 1971), p. 37.

147 H. L. Malchow, Population Pressures: Emigration and Government in Late Nineteenth Century Britain (Palo Alto, 1989), pp. 66-9; Ruth-Ann M. Harris, "Where the poor man is not crushed down to exalt the aristocrat': Vere Foster's programmes of assisted emigration in the after- 
math of the Irish Famine' in Patrick O'Sullivan (ed.), The Irish World Wide, vi: The Meaning of the Famine (London, 1997), pp. 172-94; Gerard Moran, 'James Hack Tuke and assisted emigration from Galway and Mayo in the 1880s' in Mary Clancy, John F. Cunningham and Alf MacLochlainn (eds), The Emigrant Experience: Papers presented at the Second Annual Mary Murray Weekend Seminar, Galway, 30 March - 1 April 1990 (Galway, 1991), pp. 70-94; David Fitzpatrick, 'Emigration, 1871-1921' in W. E. Vaughan (ed.) A New History of Ireland VI: Ireland under the Union II 1870-1921 (Oxford, 1989), pp. 622-4.

148 James H. Tuke, A Visit to Connaught in the Autumn of 1847: A Letter Addressed to the Central Relief Committee of the Society of Friends, Dublin (London, 1848), p. 58; Patrick Lavelle, The Irish Landlord since the Revolution with Notice of Ancient and Modern Land Tenures (Dublin, 1870), p. 163.

149 James H. Tuke, Irish Distress and its Remedies: The Land Question: A Visit to Donegal and Connaught in the Spring of 1880 (London, 1880), p. 91; The Times, 11 June 1883.

150 N.L.I., William O’Brien papers, Ms 13,552, printed circular, 'Mr Vere Foster's female emigration fund', Oct. 1884.

151 P.R.O.N.I., Dufferin papers, D/1071/H/B/F/262/1, letter from Foster to Dufferin, 5 Aug. 1883.

152 P.R.O.N.I., Vere Foster papers, D3618/D/14/30, letter from David Thompson to Foster, 6 Feb. 1880; Ibid., D3618/D/17/5 and D3618/D/17/23, letters from Thomas Eastwood to Foster, 26 Jan. 1883 and 7 Aug. 1883.

153 N.L.I., William O’Brien papers, MS 13,552, printed circular, 'Mr Vere Foster's female emigration fund, Oct. 1884.

154 P.R.O.N.I., Vere Foster papers, D3618/D/15/85, letter from P.J. McDonald to Foster, 24 Jan. 1881.

155 P. M. Pollock, 'Social life in Canada' in Presbyterian Churchman (1885), 210; The Witness, 21 July 1882; The Witness, 22 Dec. 1881.

156 Tuke, Irish Distress, p. 42; Galway Vindicator, 10 June 1882; D. M. Maclise, The Dominion of Canada as a Field for Emigrants from the United Kingdom (Ottawa, 1882), p. 13; The Witness, 21 July 1882.

157 Cusack, Case of Ireland, p. 343; Richard F. Clarke, S.J., My Visit to Distressed Ireland (New York, 1883), p. 123.

158 Tuam News, 26 Jan. 1883; Galway Vindicator 25 Apr. 1883.

159 Report from the select committee on colonisation; together with the proceedings of the committee, minutes of evidence, and appendix, p. 494, H.C. 1890 (354), xii, 509 [henceforth cited as Report on colonisation].

160 I.C.R.A., Kirby papers, KIR/1884/4, letter from McEvilly to Kirby, Jan. 1884.

161 Connaught Telegraph, 24 Nov. 1883; Mayo Examiner, 10 Nov. 1883, 17 
Nov. 1883, 24 Nov. 1883.

162 Tuam News, 16 Nov. 1883.

163 Cork Examiner, 10 Nov. 1883.

164 Reports and Papers relating to the Proceedings of the Committee of 'Mr Tuke's Fund' for assisting Emigration from Ireland during the years 1882-83-84, collected for the Private Use of the Committee (London, 1885), p. 190.

165 Hansard's Parliamentary Debates 3, cclxxxii, p. 1973.

166 Richmond Commission, 91 [C 2778], H.C. 1881, xv, 119.

167 Richmond Commission, 503 [C 2778], H.C. 1881, xv, 531.

168 Professor [Thomas] Baldwin, Introduction to Suggestions on the State of Ireland (Dublin, 1883), pp. 12-20.

169 Tuam News, 9 May 1884.

170 Tuam News, 23 May 1884, 20 June 1884; Mayo Examiner, 19 Apr. 1884; Tuam News, 9 May 1884; Mayo Examiner, 3 Apr. 1884, 19 Apr. 1884; Galway Vindicator, 11 July 1883, 12 Apr. 1884; Tuam Herald, 22 Mar. 1884.

171 Professor Baldwin, A Remedy for the Congested Districts of Ireland: Migration versus Emigration (Dublin, 1884), p. 27.

172 Tuam Herald, 7 June 1884.

173 Report on colonisation, p. 340, H.C. 1890 (354), xii, 354.

174 Liam Kennedy, 'The Roman Catholic Church and economic growth in nineteenth century Ireland' in Economic and Social Review, x:1 (Oct. 1978), 54; W. L. Micks, An Account of the Constitution, Administration and Dissolution of the Congested Districts Board for Ireland from 1891 to 1923 (Dublin, 1925), pp. 200-8; Ciara Breathnach, The Congested Districts Board of Ireland, 1891-1923. Poverty and Development in the West of Ireland (Dublin, 2005), pp. 137-44. 


\section{2 \\ The emigrant's friend?: the clergy and emigration in practice}

Although it subsequently proved to be wishful thinking, the widely held notion that an Ireland governed by Irishmen would cease to export its population en masse was, as Kerby Miller has noted, a logical counterpoint to the belief that only British maladministration had made doing so necessary in the first place. ${ }^{1}$ In the absence of the supposed balm of self-government, however, those wishing to prevent emigration had only one option: persuade would-be emigrants not to leave. That this was a tall order was starkly demonstrated by a competition held by the south Ulster newspaper The Anglo-Celt in 1901-02. An offer of a gold medal and 20 silver medals for the volunteer 'patriots' who prevented or postponed the most departures over the year attracted only one response, from a Fermanagh man whose paltry four stay-at-homes were themselves awarded silver medals for their troubles. ${ }^{2}$

However, the belief that clergymen had the power to influence individual emigration decisions had considerable currency in nineteenthcentury Ireland. Radical constitutional and economic reform aside, this influence was long thought to be the best weapon in the antiemigration armoury. Following the pattern of opinion set out in Chapter One, it was a weapon mainly deployed from mid-century onward. An uncoordinated campaign of dissuasion, largely centred on the pulpit pleas of parish clergymen, was regularly given fresh impetus by the published accounts of priests who had either settled in or visited emigrant destinations. The first of such cautionary messages was a frightening, if poorly grounded, exposé of mass Catholic 'leakage' proffered in 1836 by a Cork native, Bishop John England of Charleston. ${ }^{3}$ With its spurious statistics and scaremongering tone, England's letter set the standard for the myriad warnings 
which followed. Alarm over what one anonymous Irish-American priest called the 'death of faith' was usually given prominence. ${ }^{4}$ Robert Mullen, who in 1852 was fundraising in the United States, suggested in a controversial letter to The Tablet that as many as two million Irish Catholics had fallen by the wayside. ${ }^{5}$ New immigrants, another priest warned, 'mix with bad companions, who, if Irish, have already unlearned the teachings of their faith, and, if Americans, have no faith at all.' ${ }^{6}$ The children of emigrants, growing up in an atmosphere 'impregnated with the spirit of "no religion"', fared even worse, explained another clerical contributor to a leading Catholic journal. ${ }^{7}$

According to such warnings, neither did Irish emigrants always attain the more secure living they anticipated. In 1855 Canon Edmond Scully, a recent visitor to North America, informed readers of the Weekly Telegraph that unemployment was rife in the United States, and that only young women bound for domestic service had any prospect of work. The anti-Catholic sentiment encouraged by the emerging 'Know-Nothing' party was partly to blame, Scully claimed. ${ }^{8}$ Clergy were also apt to remind would-be emigrants that the city slums of America and Britain were already clogged with those who had gone before, their own hopeful journeys ending in misery and degradation. Worst of all, as Archbishop John Joseph Lynch of Toronto later claimed for North America, and as a private survey of England contemporaneously revealed, Irish Catholic immigrants, both male and female, tended to be over-represented in the prison population. ${ }^{9}$

Thus, lapsed, apostate, mired in immorality, uncertainly employed, even imprisoned, according to many clergy who claimed first-hand knowledge, Irish emigrants were not necessarily better off than the countrymen they had left behind. Such feeling was occasionally given vent in the most extreme terms. The image of the grave featured heavily in the clergy's anti-emigration rhetoric, and in poetic laments and Catholic periodical fiction. It was usually a reference to those Famine emigrants who did not survive the harsh Atlantic passage, or a creative expression of the knowledge that most emigrants who did make it would never return to be buried in Irish soil beside their loved ones. ${ }^{10}$ A related, subtly different religious claim was also occasionally made, however. In its mildest form, this was the sense that it was better for would-be emigrants 'to lay their bones quietly at rest in the graves of their forefathers in the "Island of Saints" than risk the moral perils which await them in the New World. ${ }^{11}$ At its worst, it was the belief that it would have been better for tens of thousands of Irish 
Catholics to have starved to death in Ireland than ever to have set foot on our shores', or the 'solemn belief' of a Fr Reardon that 'if the vessels which bring them over were suddenly to founder, and carry every creature on board into the depths of the ocean, they would have a better chance of salvation, than they have after they have lived for some time in this country' ${ }^{12}$

Faced with such dramatic claims, many priests in Ireland felt compelled to deliver sermons that urged their congregations not to risk migration. In 1852, for example, the bishop and clergy of Killaloe responded to Fr Mullen's counsel with a series of anti-emigration homilies and a concerted effort to prevent Nenagh Board of Guardians sending paupers to Canada. ${ }^{13}$ Some years later, Alexander Shand, a Times correspondent, reported Donegal priests 'solemnly denouncing [emigration] from the altar, telling their flocks that it is better to save their souls in Holy Ireland than to hazard them for this world'. ${ }^{14}$ Moreover, at the turn of the century, several of Canon Joseph Guinan's fictional clerics were depicted striving to keep the youth of their parish from emigrating, lest they become 'Methodists, jumpers, ranters'. 'Oh stay at home,' urges Fr John from the altar, 'stay at home, my people, in your own fair land. ${ }^{15}$

The effectiveness of such exhortations might best be gauged by reference to the steady emigration figures. To be specific, however, the only discernible impact of the Killaloe intervention was that twenty-two workhouse inmates decided against leaving, a dread of the unknown having been seeded. ${ }^{16}$ Hundreds more did leave, and it is likely that some of the twenty-two merely postponed their departure until positive word was received from the early emigrants. Shand, meanwhile, wrote of emigration in Donegal continuing and 'growing, notwithstanding the opposition of the priests. ${ }^{17}$ Even Guinan's fictional 'soggarth aroon' was not much more successful, being inordinately proud of having persuaded just one young couple to forego their planned passage to America. ${ }^{18}$ That pride speaks of the gradual erosion of the confidence which one priest expressed as the worst of the Famine faded: 'our influence, gentlemen, over our respective flocks, is incontestable. ${ }^{19}$ Clergy writing from abroad and sections of the press may have held on to this notion as far as emigration was concerned, but priests in Ireland seem to have adjusted rather more quickly to the reality that their ability to minimise the outflow by means of dissuasion was severely limited, as was their practical capacity to provide viable alternatives to migration. ${ }^{20}$ In 
the words of one sympathetic American Jesuit on a visit to Ireland in 1882, 'You might as well try to stem the mountain torrent, or to stop the approach of summer when spring draws to its close.. ${ }^{21}$

In a temporal context, therefore, where priests' 'main function was not to impose a course of action contrary to people's inclinations, but rather to lead all or part of their congregations in the direction in which they wanted to go, any tangible influence they exercised over the 'emigration fever' was to be ameliorative rather than preventative. ${ }^{22}$ As Oliver MacDonagh has indicated, much of this influence was exercised on a personal one-to-one basis. It is therefore reasonable to assume that the interaction between clergyman and intending emigrant often went unrecorded, being so common as to be unremarkable. ${ }^{23}$ Nevertheless, there are sufficient traces of the parish clergyman's role at every stage of the emigration process to suggest that his facilitation was routinely sought and frequently significant.

Once a decision to depart was made, practical assistance could first be asked of the clergyman regarding how to finance it. Although in a handful of recorded instances clergy gave personal or parish aid to fund a few departures, by and large their role appears to have been limited to that of broker. As Tim O'Neill has noted, in the pre-Famine era 'the priest was the only person of authority to whom the poor could turn when the charity of neighbours failed. If he was unable to give aid himself, he was in a position to solicit aid from others. ${ }^{24}$ Both Catholic and Protestant clergy duly did so in an untold number of instances. Several petitions to the Colonial Office in the wake of the Peter Robinson scheme came from clergymen seeking assistance for parishioners to emigrate. ${ }^{25}$ Clerics of all denominations were also known to lobby local landlords for passage money for distressed members of their congregation, and according to one report, Fr Mathew personally acquired free passages for 'twenty to thirty of the labouring class' from a ship's commander. ${ }^{26}$ A Father Roche, meanwhile, used subscriptions from his congregation to send twenty penitent 'prostitutes of Wexford' to nuns in Canada. ${ }^{27}$ Clergy were also able to inform their flock where free passages might occasionally be obtained. The Scottish writer Thomas Carlyle recorded meeting two 'misadventurous' Protestant sisters returning to Ennis, from whence their vicar had directed them to Plymouth to obtain passages to Australia. Alas, they were to sail among parish paupers and these daughters of a lieutenant 'shrieked (of course) at the notion of it! ${ }^{28}$ 
For many intending emigrants, however, the clergyman's first direct contribution to the process of departure was the furnishing of a character reference. This appears to have been common among all denominations. Bishop Doyle told Parliament in 1830 that 'people, generally, of the diocese in which I live, when going to America, think that a testimony of good conduct, signed by me, would be of use to them in travelling [...] so scarcely any one emigrates to America, from the neighbourhood in which I live, who does not come to me previously.29 Archbishop Murray met with similar requests, and one Limerick priest, by way of explaining that no emigration had recently taken place from his local area, stressed the perceived importance of the clergyman's role in the process: 'A single person has not emigrated to any foreign country; if they had been inclined to do so, they would first call on me and on the parish minister for characters, which has not been done. ${ }^{30}$ Indeed, a recent examination of referees cited by a sample of 1,844 'remittance emigrants' from Cavan and Fermanagh to New South Wales between 1858 and 1884 confirms that for a majority of Protestants and Catholics, a cleric, usually of their own denomination, was the first choice. ${ }^{31}$

Those references, required under the terms of a particular scheme of emigration, had a clear purpose. However, there is considerable evidence that many later emigrants, were they to acquire a general letter of introduction from their religious minister, would struggle to benefit materially from it. The Nation told readers as early as 1847 that in America, so far as employment went, 'letters of introduction are of no use [...] character is created there, not transplanted from this. ${ }^{32}$ An article reprinted from a Melbourne newspaper in 1853 was similarly dismissive. These 'imaginary treasures' had much to answer for in creating false hopes among emigrants of easy employment, and clergy should therefore 'suffer not your unwillingness to refuse what seems a small request. ${ }^{3}$ The Church of Ireland canon James Hannay, otherwise known as the author George Birmingham, was wise to the use made of such character references, having once been told by an employer that 'when considering the characters of applicants for posts in his gift he always began by putting all letters of recommendation from clergymen into the waste-paper basket without reading them. ${ }^{34}$ If not useful for employment, such letters did have a more explicitly religious purpose, introducing the holder to a new minister on arrival, while confirming their good standing in their home church; the Orange Order operated a similar system of references for those joining lodges in their new 
homes. ${ }^{35}$ However, as one Presbyterian clergyman warned from New York, 'in some instances, unhappily, letters lie in the bottom of trunks for years, and are only disinterred when the possessor needs help, or is trying to regain lost character in fresh fields. ${ }^{36}$

Perhaps of more use was the practical training that appears to have been offered by some clergy and nuns to would-be emigrants. While the improved employment prospects of those migrants who had been through church-run industrial schools in Ireland was sometimes implied, ${ }^{37}$ Father Daniel Cahill, writing home from the United States, may have been the first to suggest that the church intentionally set out to provide intending emigrants, particularly females, with particular skills that might make them a success in the new world. Nuns and bishops in Ireland, he urged, should have them clean the convent and cathedral silver, thus allowing them to aspire to work in the parlours rather than the sculleries of American houses upon their arrival. ${ }^{38}$ By the 1880s, such training appears to have been a relatively common practice. One clerical visitor to Roscommon found the nuns teaching local women how to cook, sew and iron, which, as he acknowledged, was as much training for domestic service in emigrant destinations as it was for marriage in Ireland.$^{39}$ Around the same time, Mary Frances Cusack, the famed Nun of Kenmare, sought to open a convent and training home at Knock, Co. Mayo which would offer 'particular training' for female intending migrants, despite her well-known opposition to emigration in the abstract. ${ }^{40}$

Home clergy continued to play a part once the emigrant had departed. A melancholy manifestation of this role was involvement in the often fruitless search for missing relatives. Priests, on request, might write to a counterpart in the diocese in which the emigrant was last known to have resided, seeking information. ${ }^{41}$ Where communication was maintained, the priest still had a role. The significance of chain migration from nineteenth-century Ireland can hardly be overstated. Satisfactory accounts of previously departed friends and relatives tended to be the greatest encourager of further migration, and the money they remitted was the most common means of financing it, meaning that one 'pioneer' emigrant from a locality might be the means of bringing out several more. ${ }^{42}$ Clergymen were often vital links in this chain. Particularly before the development and spread of a modern postal service, 'American letters' were routinely addressed to a local clergyman, and even later, in the continued absence of a post office in many smaller towns, this familiar channel continued 
to be used. ${ }^{43}$ 'Sure every post-boy knows the priest' as one writer had it. ${ }^{44}$ Indeed, better-known figures were beacons for such communication. Bishop Doyle confirmed that he was 'often the medium' of what he described as 'constant and extensive' correspondence between emigrants and those left behind, while Fr Mathew told Parliament of 'hundreds and hundreds' of letters directed 'to John Ryan or William So-and-so in such a place, as if those persons were all well known, "to the care of Father Mathew in Cork"'.45

Even so elevated a figure as Doyle was also often called upon to read these (perhaps dictated) missives aloud to illiterate recipients, and there is good cause to suppose that, for one reason or another, clergymen of all persuasions regularly read emigrant letters sent to members of the local community. ${ }^{46}$ Some literary evidence also suggests that a priest (or parson or schoolmaster) might be asked to recite an American letter for a gathering of neighbours eager to hear news of all local emigrants. ${ }^{47}$ More importantly, the clergyman was also likely to be entrusted with what for many were the only kind of emigrant letters that mattered: those containing remittances. Schrier notes that, even with the advent of an international postal money order system in 1871, priests continued to act as conduits for remittances as late as the $1890 \mathrm{~s} .{ }^{48}$ Fr Mathew reported receiving sums of up to $£ 50$, Bishop Doyle spoke of 'considerable sums transmitted through [his] hands' and several other ministers confirmed before Parliament that amounts ranging from $£ 3$ to $£ 10$ were frequently sent by emigrants, whether as a pre-paid passage ticket to enable family members or friends to join them, or as cash to relieve elderly parents who would not leave. ${ }^{49}$ One pre-Famine traveller in Longford even marvelled that 'Catholic emigrants send their remittances to the care, not of the Catholic priest, but of the Protestant clergyman, to be distributed by him among those pointed out. ${ }^{50}$ This 'curious fact' had a long afterlife, being continually rehashed by interested parties keen to posit a more general distrust of priests and a widespread acceptance among Catholics that money given to the Protestant rector initially including tithes, of course - was money well-directed. ${ }^{51}$ More likely it reflected a learned aversion to one particular unreliable priest. However, the point remains that clergymen of one stripe or another were widely treated by emigrants and would-be emigrants as unofficial bankers, brokers, postmasters and readers, whether they wished to be or not. As one priest told Parliament when asked if 'this kind of benevolent commission business' took up a considerable amount of 
time: 'No doubt of it; and it gives me a vast deal of annoyance. ${ }^{52}$

Through this practical facilitation, parish clergymen smoothed the path of many an emigrant. Nevertheless, as the volume of emigrants increased from the Famine onward, it became clear that there were also larger problems of migrant welfare to be addressed. In the ports of embarkation and arrival, and on board ship, emigrants were perceived to be subject to myriad temporal and spiritual dangers. The evocatively titled 'man-catchers' who patrolled the docks at Liverpool, New York and elsewhere using charm and empty promises to trick unworldly migrants were chief bogeymen, but the negligent ship's captain, the fraudulent ticket-broker, and the keeper of filthy, overcrowded and 'immoral' port-side lodging houses had also to be thwarted. ${ }^{53}$ The state, as Oliver MacDonagh showed in his pioneering study of the Passenger Acts of the mid-nineteenth century, eventually provided stringent protective laws, but not the resources necessary to enforce them. ${ }^{54}$ Into the breach stepped well-meaning private individuals like Caroline Chisholm, Stephen de Vere, Vere Foster and later, with a specific concentration on female emigrant welfare, Charlotte Grace O'Brien and Mary Townsend. ${ }^{55}$ Given the moral aspect to fears over emigrant welfare in transit, it might be expected that members of the clergy also found a role in attempting to mitigate these problems.

To be sure, clergy based in port towns could not fail to be drawn into such activity. The more obvious facets of their remit extended from giving the final 'heavenly nourishment' or prayers before embarkation, to, in the case of Catholic priests, offering rosary beads, scapulars or Agnus Dei relics for the journey, and in the case of Protestant ministers furnishing bibles. ${ }^{56}$ They were also well placed to anticipate problems that might arise on the voyage and check any potentially 'immoral' behaviour at sea. The Catholic Bishop of Cork, for instance, twice wrote to Rome seeking extra-matrimonial dispensations allowing his priests to perform marriage between distantly-related members of emigrating family groups before they embarked from Cork, as they might otherwise 'proceed on their voyages [and] run the risk of incestuous intercourse. ${ }^{57}$ The Liverpool-based Anglican clergyman John Welsh, who estimated that he saw a third of all emigrants who passed through the city, many of them Irish, also admitted that he frequently went on board ships docked in the harbour to give a final blessing, only to encounter young girls who had been berthed inappropriately, sharing with single men or married couples. He endeavoured to have such situations rectified by the relevant authorities. ${ }^{58}$ 
If the potential immorality of steerage sparked clerical fears across denominations, the nature of religious provision aboard ship could be equally worrisome. The close confines of the vessel could give way to quarrels 'on the score of religion', as one early traveller noted, and the Emigration Commissioners' 1848 decree that Sundays 'be observed as religiously as the circumstances permit' merely sowed the seed of further discontent. ${ }^{59}$ In the usual absence of a clergyman, the ship's captain or doctor could act as surrogate chaplain, normally reading prayers according to the Church of England. Meanwhile, in Herman Melville's words, 'the heathen at the other end of the ship were left to their false Gods and idols. ${ }^{60}$ As Caroline Chisholm noted, this allowance was 'by courtesy at present' and while she saw no further need for regulation on the matter, as one America-bound Presbyterian minister discovered, the courtesy was not always extended. Jonathan Simpson recorded his first attempt to hold prayers below deck being 'much interrupted by sailors and other scoffers', so that he had to ask the captain's protection for further assemblies. ${ }^{61}$

Differences in the forms of religious observation among passengers could cause other tensions. 'A Kerryman' complained furiously to a Catholic newspaper of 'plebian theologians [...] who had all the advantages they could desire every evening during divine service. All forms of amusement were to be put aside, thus debarring people who would not, nor could not, join them, of the rights of enjoying themselves, and granting an undue prerogative to the most bare-faced hypocrisy'.62 Conversely, Robert Louis Stevenson met an elderly Scotswoman on his trip westwards who, having seen a fellow passenger merely holding a chessboard on a Sunday, expressed surprise that 'the ship didnae gae doon. ${ }^{3}$ Others, like the Australia-bound Rev. William Bates and Robert Whyte, who described a voyage to Quebec in 1847, encountered Protestants and Catholics alike blithely failing to observe the fourth commandment. ${ }^{64}$ Therefore, not keeping the day holy, or being obliged to keep it 'in a dull Scotch fashion, alongside the common reality of having to negotiate with the captain to allow any religious gathering amenable to the non-majority creed on board, cannot have inspired much confidence in home clergy that emigrants would remain untainted. ${ }^{65}$

Consequently, there was trepidation on all sides that the religiously mixed atmosphere of emigrant ships provided an ideal environment for proselytism. The French priest Adolphe Perraud was fearful that where a chaplain was present on ships carrying Irish Catholic 
emigrants, he would most likely be Protestant and 'far from being a consolation and a safeguard, may easily become a source of peril and oppression.66 Partisan newspaper reports occasionally confirmed the worst anxieties. In 1853 The Tablet alleged that a young Catholic Irishman had found himself on a ship to Canada 'full of Orangemen' who attempted to engineer his conversion, while a few years later, the Belfast News Letter accused a Fr Moore of converting two Protestant girls on a trip to Australia. ${ }^{67}$ There were also examples of ecumenism on board ship. According to one recollection, the efforts of one ship's captain to stop daily Mass were opposed by every Irish passenger, Orangemen included. ${ }^{68}$ That the captain had tried to curtail religious expression at all was likely to have been the lesson for most clergymen, however. Mindful of such possibilities, an acolyte of Archbishop Cullen wrote to the Emigration Commissioners in 1859 demanding unrestricted access to all parts of the ship for Catholic clergy and citing rules governing public hospitals, gaols and poorhouses in his favour. ${ }^{69}$

In many instances, however, even the chance presence of a clergyman on board ship did not guarantee spiritual supervision for his co-religionists, let alone imply the evangelism of others. Fr Michael Buckley, for one, spent his outward voyage learning French from a fellow passenger and although the captain gave him a room in which to have prayers on Sundays - while the ship's doctor read an Anglican service in the saloon - only three passengers attended. From that point Buckley seems to have relinquished any claim to act as unofficial Catholic chaplain. He refused an invitation to preach a sermon to the entire, inter-denominational cabin congregation, being 'deterred by the novelty and difficulty of the task' and it is not apparent that he concerned himself with the spiritual welfare of the 350 steerage passengers at all. ${ }^{70}$ Likewise, James Strain, a Belfast Presbyterian minister, found when he travelled to America, that there were four clergymen on board: 'A weight of divinity enough to sink the ship' [yet] 'none of them but myself was present at the Captain's prayers.' There were similar experiences of neglectful clerical passengers in the Anglican Church; hence the 1888 Lambeth Conference resolution that clergy travelling to the colonies should be specifically invited to act as on-board chaplains, rather than leaving it up to their own consciences to do so. ${ }^{72}$

That this resolution came from the only church that made any systematic attempt to provide chaplains for emigrant ships - via the 
'Emigrants' Spiritual Aid Fund' sponsored by the S.P.G. (Society for the Propagation of the Gospel in Foreign Parts) - indicates the limitations of such efforts. ${ }^{73}$ Churches, government and even shipping companies could agree that having chaplains on board emigrant vessels might be helpful, for temporal as much as for religious reasons. In particular, the power of clergymen to resolve inevitable disputes over the mundanities of ship life such as access to cooking pots was recognised as making for a more harmonious voyage. ${ }^{74}$ However, legislation for chaplains was never forthcoming, nor would it have been practically possible to apply it. When such a measure had been contemplated, towards the end of the 1840s, the Catholic Archbishop of Dublin told the Colonial Office that he could not spare the priests. ${ }^{75}$ In truth, no Irish religious leader at any time could have been expected to provide chaplains for every one of thousands of emigrant ships. Even if the churches had possessed the requisite number of clergy, and the funds to keep them had been forthcoming, it would likely have proved difficult to persuade so many young men to commit to months or even years spent on shipboard, an environment which, as one colonial clergyman noted, Dr Johnson had only half-jokingly termed 'prison - with the chance of being drowned. ${ }^{76}$ Most emigrants who worried about such things had therefore to content themselves with whatever comfort their bibles or relics could offer.

What was ostensibly feasible for the churches to provide, however, was a more organised and dedicated portside presence. In theory, this would not only be less demanding of personnel, but would also exploit the churches' privileged positions as institutions with strong transnational bonds. If a parish in Liverpool or Queenstown was formally linked to a parish in Quebec or New York, allowing emigrants to be both seen off and greeted on arrival by clergymen, fears over the voyage itself might be attenuated. Yet the efforts of the churches in this regard were each a combination of patchy, underused, under-funded and/or late. The Church of Ireland, by once again piggybacking on the occasionally exemplary provisions of its sister church, appears to have been the most successful of the three. The abovementioned John Welsh was one of several emigrant chaplains billeted by the S.P.G. at ports of departure and arrival, although by the 1880s, a shortage of such ministers and differences in the levels of their attentiveness can be noted..$^{77}$ Nonetheless, these formal structures trumped those of the Presbyterian Church. It was not until 1894 that the General Assembly formed a committee to examine the possibility of making 
arrangements 'in association with the committees of other churches, for the care of emigrants on leaving the home ports and for showing them kindness on their arrival in the Colonies. ${ }^{78}$ Even then, after issuing one vague report the committee was discharged and the idea abandoned within four years. ${ }^{79}$

It ought to be noted that an earlier attempt to have suitable clergymen receive and protect Ulster Protestant emigrants on their arrival in America had been made in 1859, when John Cooke (probably related to Rev. Henry Cooke, who said he had known him 'since he was the height of the stick in my hand') was sent home from New York to Belfast by 'philanthropic Christian men' to act as agent of the 'American Friendly Association for Irish Emigrants'. ${ }^{80}$ At its inaugural meeting, a significant gathering of Belfast evangelical clergymen led by Robert Knox, Anglican Bishop of Down and Connor, and Henry Cooke, were informed of the services, including religious, which the Association proposed to offer. Emigrants who visited Mr Cooke at his office in Donegall Square would receive a letter of introduction to be given to the Association's agent in New York; a committee of evangelical clergymen would then '[take] the emigrants under their hands, and [do] everything possible for them. They [take] them to their respective ministers, who then look after their interests. ${ }^{81}$ Knox and Cooke therefore joined the Banner of Ulster in suggesting that no emigrant should leave Belfast for New York without first calling on Cooke's office. ${ }^{82}$ However, though apparently well used by intending emigrants, this Association, somewhat curiously, endured for less than a year. ${ }^{83}$

The Catholic Church's record on emigrant reception at ports was equally fitful and delayed, but also relied entirely on external or lay initiatives to which it then lent some measure of support. The Emigrants' Protection Society, described by the historian Oliver MacDonagh as an 'eleventh hour Catholic recognition of the needs of emigrants', was the initiative of the St Vincent de Paul Society. Founded in 1850, it had some success in combating the worst excesses of Liverpool's 'man-catchers', being instrumental in opening one of only two 'respectable' boarding houses in the city. ${ }^{84}$ However, by 1853 , despite Paul Cullen's hope that it would eventually carry out its work 'on an extensive scale', the E.P.S. was all but defunct. An incredulous Freeman's Journal reported that of some 400,000 emigrants in the previous two years, only 980 had visited E.P.S. offices. ${ }^{85}$ Money was, as ever, an issue, but having sought the cooperation of parish clergy 
in Ireland in referring emigrants to it, members of the society were inclined to think that there must be much apathy on the part of the several persons who have been written to, and who, they think, ought to take a greater interest in forwarding the undertaking. ${ }^{86}$

A later endeavour by Charlotte Grace O'Brien (the daughter of William Smith O'Brien) also failed to capture the Irish Catholic Church's whole-hearted cooperation. Having interested herself in the plight of 'unprotected' single female emigrants - who formed a disproportionately large number of the Irish exodus in the later nineteenth century ${ }^{87}$ and attracted a good deal of moral panic as a result - O'Brien attempted to persuade the Catholic Church to open a safe boarding house for them at Queenstown. This was to no avail, and she subsequently founded, ran and largely funded the home herself. ${ }^{88}$ Mindful of the need for a corresponding protective institution on the other side of the Atlantic, O'Brien travelled to the United States in 1882 and once again solicited the active participation of the Catholic Church ${ }^{89}$ She later recalled telling Bishop Ireland of Minnesota, 'I am only the plank over the stream, it is you, the Catholic Church, who have to build the bridge..$^{90}$ Her efforts were rewarded in 1884 when the Mission of Our Lady of the Rosary for the Protection of Irish Immigrant Girls was established in New York under the enthusiastic administration of the American Church. According to one of its chaplains, Patrick McCool, the Mission saw a quarter of all Irish females who immigrated through New York in the ensuing decade. ${ }^{91}$ However, when McCool later attempted to complete O'Brien's 'bridge' by asking the Irish church to consider setting up a sending mission in Ireland, he hit a wall. Despite rhetorical support for the work in New York, and interest from some parish priests in the north west of Ireland, the Irish hierarchy offered only the classic evasion of an inquiry, from which no report, let alone any action, ever resulted. ${ }^{92}$

At the institutional level, therefore, the Irish churches, particularly Catholic and Presbyterian, failed to mobilise their resources effectively in the cause of emigrant protection. As the above suggests, there were certainly countless individual and private kindnesses from clergymen to shield some emigrants from an otherwise miserable fate. However, as many commentators and philanthropists recognised, the scale of the challenge meant that structured, collective action was required if the overwhelming majority of emigrants were not to slip through the net. If the government was not prepared to police ports and ships to a sufficient standard, the onus was arguably on the churches to step 
in, even simply through more active cooperation with private charity. Instead, the matter was left to the consciences of individual clergy, who sometimes came up to the mark and sometimes did not.

A handful of individual clergymen, however, were able to help emigrants with whom they never came into direct contact. If the American letter was the primary source of information for would-be emigrants, published emigrant guides had a strong claim to second place. ${ }^{93}$ With their insights into emigrant correspondence and its shortcomings (chiefly an exaggerated positivity) and their increasing propensity to travel to emigrant destinations in the course of their duties, clergymen were in a unique position to author such guides. ${ }^{94}$ In particular, clergy who perceived discrepancies between what they had read and what they saw with their own eyes felt obliged to act. ${ }^{95}$ Accordingly, a number of clergymen offered their sincere advice to emigrants via handbooks and article series in newspapers, with the objective, as most of them emphasised, of neither encouraging nor promoting emigration but of safely directing a flow that they accepted they could not stop. ${ }^{96}$ In that sense, their advice differed from that often given from the pulpit since its aim was to make emigration as safe and as successful as possible rather than to simply discourage it in all instances.

To this end, many guide authors provided checklists of persons judged to have scant hope of succeeding - the intemperate and the unskilled featured highly - and of pitfalls that the better-equipped should avoid. ${ }^{97}$ Most also argued the case for a particular country, state or colony as the best field for emigration. Frequently, that was determined by whatever locality was most likely to provide land for the immigrant to farm. Indeed, a principle common to all guides, whether written by Catholic, Anglican or Presbyterian ministers, was the imploration to go beyond the grimy port cities that so often marked the end of the emigrant's progress - in every sense - and venture inland for a more pastoral existence. ${ }^{98}$ Very often, and especially in the case of Catholics migrating to the United States, this advice was mere wishful thinking. ${ }^{99}$ As thelikes of Daniel Cahill and Alexander Peyton admitted, land needed capital to develop if not to acquire, and most emigrants had none. ${ }^{100}$ Neither did they necessarily have the skills needed to go from small Irish holdings, which one guide author termed 'miserable little patches of land, which by stretch of charity and an abuse of language we call 'farms", to clearing and cultivating hundreds of acres in the new world. To that extent, many of the guides were not wholly grounded in the temporal reality that faced most emigrants. ${ }^{101}$ 
There was also considerable irony in churchmen universally urging settlement, not in the great emerging cities of the American east coast or the Australian colonies, where impressive cathedrals and churches had already been built, but in as yet undeveloped and remote regions where access to religious services was likely to be infrequent at best. Guide authors acknowledged the problem, but offered only imperfect solutions. Protestant clergy had the easier task. The Church of Ireland rector William Hickey was able to suggest that 'the good Christian has always a Friend above, to whose willing ear he may address himself', while also encouraging young vicars to consider emigration to Canada to supply the spiritual wants of settlers. ${ }^{102}$ The Presbyterian minister David MacKenzie could note of Australia that 'in the wilderness you may live near to Him, enjoy His favour, hold daily communion with Him, and experience that peace of mind and joy in believing, which the world can neither give nor take away' ${ }^{103}$ For Protestant emigrants of all denominations a personal relationship with God, enhanced by regular recourse to the scriptures and perhaps by a proximity to nature in an unspoilt landscape may have been seen as an acceptable temporary substitute for having a church or a parson nearby.

Catholic priests were unable to suggest the same, and although the issue loomed large, it was addressed in a variety of problematic ways. Some authors felt the matter would be resolved with patience. Emigrants might be without spiritual guidance for a few years, but in time, as the population grew, chapels would be built and priests would be supplied. In the meantime, emigrants were expected to attend to their religious duties at least once a year, at Easter, and instruct their children in the Catholic faith. ${ }^{104}$ Stephen Byrne, meanwhile, suggested that rich New York Catholics should fund and create a million-strong Catholic colony in the southern states, a proposal which had much in common with the 'western colonization' dreams of certain American bishops including John Timon of Buffalo, John Ireland of Minnesota and especially John Lancaster Spalding of Peoria. ${ }^{105}$ This was almost certainly unrealisable on the scale Byrne envisaged, and there was also the still-persuasive argument first put forward by the late Archbishop Hughes of New York that it would be counterproductive to remove people from the centres of religion. ${ }^{106}$ Other guide writers believed that clever forward planning was all that was needed. John O'Hanlon envisaged his readers consulting the US Catholic almanac to find where churches were located in the interior, while Cahill stated that 'care and correspondence' could elicit the same information. ${ }^{107}$ 
Such suggestions seem optimistic to say the least. Most Catholic guide authors therefore failed plausibly to reconcile their temporal and spiritual advice to emigrants.

There was, finally, one obvious way in which clergymen could practically assist the emigration of their parishioners with a view to protecting them from its harsher realities. A visiting American priest, Fr Dowling, alluded to it at a meeting in Clonakilty in 1901, when he reportedly told his audience that, 'no nation ever took to emigration like Germany. They had whole parishes moving out and settling in America with the parish priest at their head. He did not think that they would get the worthy parish priest of Clonakilty to head his flock that way.'108 On that specific point, Dowling was no doubt correct, but a few Irish priests did 'head their flocks that way'. Precisely how many is difficult to ascertain with any confidence. Oliver MacDonagh noted two cases during the Famine in Thomas Hore of Wexford and, with rather less practical impact, James Maher of Carlow, but there were certainly more, even within the timeframe of MacDonagh's study. ${ }^{109}$ A difficulty arises in that, even at the time, such projects were not well known. David Moriarty told a parliamentary committee in 1854 that he knew of only one such case, that of Hore. ${ }^{110}$ If a recent former president of All Hallows Missionary College, a man who took an interest in emigration matters, was not aware of other similar endeavours that received attention in the national press, it intimates that still others may have remained localised and lost to history. Indeed, Jim Rees, historian of the Hore emigration which saw 1,200 people migrate to America in 1850, has noted that the priest seems not to have used the press to publicise his scheme, but more likely had it announced from pulpits throughout the south-east. ${ }^{111}$ It is easy to see then how smaller schemes might have escaped national attention altogether.

Indeed, there may have been good reason to keep quiet about such projects. Maher's highly publicised and ambitious 'Leinster Emigration Society', which urged farmers to make the best of their lot by emigrating in groups to be chaperoned by priests and doctors, certainly attracted a deal of answering criticism. Maher had a formidable reputation as 'a consistent friend of his country and his countrymen', which may explain the extensive and mostly respectful hearing his ideas were accorded in the press, but his proposal was not without controversy in clerical circles. ${ }^{112} \mathrm{He}$ appears to have had tacit acceptance from his nephew Paul Cullen, then still the rector of the Irish College in Rome, who he informed of the plan in its earliest 
stages. ${ }^{113}$ However, Cullen's opposite number in Paris, Dr John Miley, publicly rejected Maher's idea at a meeting on Famine relief in Dublin, pointing to the 'blessed soil' awaiting regeneration in Ireland. ${ }^{114} \mathrm{He}$ furthermore privately expressed his fears that Maher would influence to leave many of the very class - better-off farmers - that represented the 'mainstay' of Irish Catholicism. ${ }^{115} \mathrm{Fr}$ Thomas Cullen expressed a parallel fear that the land of those who left might be taken over by 'young Protestants.'116 These attitudes, significant in their own right as we shall see, may have contributed to the demise of Maher's plans.

Other clergymen were undeterred from their path, however. Fr John Doran of Aghaderg near Loughbrickland in Co. Down wrote several times to the Freeman's Journal in 1849-50 in order to promote his plan of organised emigration. He had visited the United States in late 1849 with a view to finding land on which to settle a group of his parishioners, and was initially reported to have entered into a deal to purchase 25,000 acres in New York State. In this respect, he was apparently influenced by the organised manner in which Dutch and German emigration was carried out, with societies formed at home, reconnaissance trips made to the destination, and ships specially chartered. ${ }^{117}$ Doran was also obviously heartened by Maher's efforts, but his entreaty to him to head a national movement of emigration societies appears to have gone unheeded. ${ }^{118}$ In the end, Doran went further than Maher by actually leading 'a number' of his parishioners to the United States in June 1850, although it is unclear precisely where they ended up. ${ }^{119}$

Mere fragments of other colonisation projects and proposals from Irish priests have survived. In 1845 'A Catholic Priest' (also identified as Rev. 'N.N.') proposed to temper some of 'the helplessness of isolated individual enterprises' by taking three hundred people to form a colony in Wisconsin. He had the backing of the Bishop of Milwaukee and an Irish priest based in Wisconsin, William Quinn, as well as the 'Wisconsin Irish Emigrant Society'. He noted that 'persons willing to join the colony will be communicated with, when their intentions are made known, through letters post-paid, directed to the "Irish Catholic Colonization Society". He provided only the Freeman's Journal offices as the return address, and the fate of the enterprise is unknown. ${ }^{120}$ Another priest's plan to settle emigrants in neighbouring Iowa certainly was not carried out, for the simple reason that he changed his mind as to its wisdom after visiting the state in 1849. This fairly damning judgement on the place could not be reversed by 
an appeal from some Irishmen in Dubuque who hoped that 'the Rev. Mullen and his friends may yet become citizens of Iowa. ${ }^{121}$ There is mention that he may have set his sights on Wisconsin or Michigan instead, but no further trace of the project can be found. ${ }^{122}$ Finally, Michael Bugler, a Killaloe curate sent to fundraise in the United States in 1851, reportedly brought with him 'a large number' of emigrants, for whom he found employment. 'He breathes an anxious sigh,' a local newspaper recorded, 'that he had means to pay the passage out of the crowds of virtuous and industrious young females who are now pent up in the Union workhouse of Borrisokane, and for whom he could obtain remunerative employment where he is located.' ${ }^{123}$ Given the later controversy in his diocese on workhouse emigration, it is unlikely he was able to fulfil this hope.

The timing of most of these endeavours is instructive. Clerically organised and planned emigration schemes were in part the ultimate symptom of the despairing feeling of many clerics - after five unremitting years of death and emigration - that there would soon be insufficient parishioners in Ireland from whom to scrape an income and to whom to minister. ${ }^{124}$ That priests might be forced to pack up and follow their flocks, just as certain Presbyterian clergy had felt obliged to in the previous century, seemed for a time a very real possibility. ${ }^{125}$ The idea of leading their parishioners, as in the continental model of emigration, rather than following them clearly seemed preferable to some, notwithstanding the class differentials between priest and people that Owen Dudley Edwards has suggested prevented a more widespread resort to that contingency. ${ }^{126}$ This particular brand of despair was temporary, however. As it became apparent in the post-Famine decades that a new emphasis on devotional practices meant congregations were strengthening rather than withering away, any hint of a need for parish clergy to cut their losses and emigrate alongside their flocks had dissipated. Moreover, as opinion hardened against emigration during the same period, the mere idea of a priest leading members of his congregation abroad became unthinkable. Patrick Dunne, a Tullamore priest who acted as agent for Bishop James Quinn in the Queensland Emigration Society in the early 1860s, had to defend himself against charges of 'encouraging the people to leave the country' ${ }^{127}$ while James Nugent, a Liverpool-based priest who cooperated with Bishop Ireland of Minnesota in a colonisation plan in the early 1880 s, was met with the dismay of priests in Ireland. As 'A Catholic clergyman' told the Nation, 'the energy, zeal, 
and philanthropy of Father Nugent, and of those associated with him in the "scheme of emigration" would be far better directed by being employed in keeping the Irish at home, and trying to find some means of subsistence for them in their own country' ${ }^{128}$

A great deal of practical involvement was therefore expected of Irish clergymen when it came to emigration from their congregations. Catholic priests were continually called upon to prevent it, whether through the power of persuasion or, latterly, through involvement in local economic initiatives designed 'to keep the people at home. One commentator roundly criticised priests in 1906 for merely exhorting and failing to show emigrants that a living might be made in Ireland. However, while 'Pat' aimed 'to make an economist of every priest' in the country, he ought to have been aware that the previous two decades had seen an upsurge in church-supported 'buy Irish' campaigns, in clerical encouragement of agricultural improvement and cottage industries, and in the close involvement of clergy with the Congested Districts Board and, more conditionally, the Co-operative Movement. ${ }^{129}$ Catholic clergymen can hardly be blamed that these endeavours did not work as hoped, and they could not therefore live up to their own and others' fervent wish that they might staunch the flow of emigration. Ultimately, in common with Protestant clerics, priests could merely meet the expectations of the emigrants themselves. On the whole they were able neither to strategically encourage nor to discourage their leaving, but merely to facilitate them and, in too few instances, perhaps alleviate some of the grosser iniquities that they encountered.

\section{Notes}

1 Enda Delaney, Demography, State and Society: Irish Migration to Britain, 1921-1971 (Liverpool, 2000); Enda Delaney, Irish Emigration since 1921 (Dublin, 2002); Miller, Emigrants and Exiles, p. 248. There was a more benign version of this theory: as the Anglican Canon James Hannay [George Birmingham] noted, a political settlement might allow minds occupied by political questions to settle the economic and social problems which caused emigration. James O. Hannay, 'The lure of the city' in Irish Church Quarterly, i:3 (July 1908), 199-211.

2 The Anglo-Celt, 19 Oct. 1901, 30 Aug. 1902.

3 See Peter Guilday, The Life and Times of John England, First Bishop of Charleston (1786-1842) (2 vols, New York, 1927), ii, pp. 352-76; The Works of the Right Rev. John England, First Bishop of Charleston, ed. Ignatius 
Aloysius Reynolds (5 vols, Baltimore, 1849), iii, pp. 224-46. The letter was reprinted as John England, 'Missions of the United States' in Annals of the Propagation of the Faith, i:2 (Feb. 1838), 73-103. For the exposure of England's fundamental errors see Gerald Shaughnessy, Has the Immigrant kept the Faith?: A Study of Immigration and Catholic Growth in the United States 1790-1920 (New York, 1925), pp. 224-31; see also David Noel Doyle, 'Irish Catholicism in the diaspora: the case of the United States' in Brendan Bradshaw and Dáire Keogh (eds), Christianity in Ireland: Revisiting the Story (Dublin, 2002), pp. 231-49; Roger Finke and Rodney Stark, The Churching of America, 1776-1990 (New Brunswick, 1992), pp. 110-15.

4 The Nation, 29 Nov. 1851.

5 The Tablet, 10 Apr. 1852. [See pages $186-90^{*}$ ].

6 Armagh Guardian, 10 Aug. 1855.

7 'Peregrinus', The falling off of Irish Catholics in the United States, and its causes' in I.E.R., iii (1867), 433-47.

8 W.T., 20 Jan. 1855, 27 Jan. 1855. Although at least one historian disputes that any employment discrimination resulted from the short-lived KnowNothing movement. Richard Jensen, "No Irish need apply": A myth of victimisation' in Journal of Social History, xxxvi:2 (Winter 2002), 405-29.

9 Gerald J. Stortz, 'Archbishop Lynch's The evils of wholesale and improvident emigration from Ireland (1864)' in Éire-Ireland, xviii:2 (Summer 1983), 6-16; N.L.I., Monsell of Tervoe Papers, Ms. 20, 683, letter from Rev. J. S. Flanagan, Adare, to William Monsell, 6 Nov. 1864.

10 John MacHale, Letter to the Right Hon. Earl Talbot, Alton Towers (Dublin, 1848), p. 28; 'B. M.', 'The young emigrant' in Duffy's Fireside Magazine: A Monthly Miscellany, iii:30 (1853), 172-5; 'D. G.' [Rev. David Gallery], 'The emigrant girl' in Irish Monthly, vii (1879), 532-3; Magdalen Rock [Ellen Beck], 'A last Sunday in Ireland', Ibid., xix (1891), 101; Magdalen Rock, 'A churchyard scene', Ibid., xix (1891), 179; Magdalen Rock, 'An exiled widow's request', Ibid., xxi (1893), 463; Mrs Fitzsimon, 'The Irish emigrant in North America in Charles Gavan Duffy (ed.), The Ballad Poetry of Ireland (Dublin, 1869), pp. 63-4; The countess of Gifford, 'Lament of the Irish emigrant' in Ibid., pp. 41-3.

11 The Tablet, 12 May 1855.

12 F.J., 7 Mar. 1894; Manchester Guardian, 11 Sept. 1855; Anon, 'Irish wastelands', 293-4.

13 The Nation, 15 May 1852; Limerick Reporter and Tipperary Vindicator, 20 Apr. 1852, 18 May 1852; F.J., 21 April 1852.

14 Alexander Innes Shand, Letters from the West of Ireland 1884 (Edinburgh, 1885), p. 115.

15 Joseph Guinan, Scenes and Sketches in an Irish Parish, or Priest and People in Doon (Dublin, 1903), pp. 73-4; see also Joseph Guinan, The Soggarth Aroon (Dublin, 1907), pp. 199-200. 
16 Daniel Grace, The Great Famine in Nenagh Poor Law Union, Co. Tipperary (Nenagh, 2000), pp. 196-8.

17 Shand, Letters, p. 115.

18 Guinan, Soggarth Aroon, p. 180. In 1853 one newspaper reported that a Galway priest, Fr Cavanagh, managed to prevail on 'several of the most independent and respectable of his parishioners to remain at home for this season' [emphasis added]. Armagh Guardian, 11 Mar. 1853.

19 The Nation, 15 Dec. 1849.

20 Southern Star, 4 Jan. 1902; C.D.A., Croke papers, 1887/21: microfilm, N.L.I., p. 6010-13, letter from P. O'Connell to Croke, 10 June 1887; 'Fr Dunne's defence of emigration' in Irish Catholic Directory and Almanac (1865), p. 366; I.C.R.A., Kirby papers, KIR/NC/1/1860/34, letter from Cullen to Kirby, 27 Apr. 1860; Abortive parish-based efforts to improve local economies with a view to preventing emigration are found in The Nation, 29 May 1852 and F.J., 26 Dec. 1853.

21 Clarke, My Visit to Distressed Ireland, p. 138.

22 S. J. Connolly, Priests and People in Pre-Famine Ireland (Dublin, 1982), p. 260. The same point is made in J. H. Whyte, 'The influence of the Catholic clergy on elections in nineteenth-century Ireland' in English Historical Review, lxxv:295 (Apr. 1960), 248; in Eugene Hynes, 'The great hunger and Irish Catholicism' in Societas, viii (Spring 1978), 147-8 and in Eugene Hynes, Knock: The Virgin's Apparition in Nineteenth-Century Ireland (Cork, 2008), passim.

23 MacDonagh, 'Clergy and emigration', 287.

24 Timothy P. O’Neill, 'The Catholic church and relief of the poor, 1815-45' in Archivium Hibernicum, xxxi (1973), 135.

25 Third report from the select committee on emigration from the United Kingdom, 1827, p. 486, H.C. 1826-27 (550), v, 708; p. 491, H.C. 1826-27 (550), v, 713.

26 Ignatius Murphy, The Diocese of Killaloe 1800-1850 (Dublin, 1992), p. 220, pp. 228-9; Armagh Guardian, 4 May 1847.

27 F.J., 29 July 1858.

28 Thomas Carlyle, Reminiscences of my Irish Journey in 1849, ed. James Anthony Froude (New York, 1882), p. 27.

29 Second report on state of poor, p. 396, H.C. 1830 (654), vii, 572.

30 D.D.A., Murray Papers, 31/8/11, letter from W. Brennan to Murray, 15 Apr. 1840; D.D.A., Hamilton papers, 37/2/111, letter from Robert Bowes to Archdeacon Hamilton, 2 June 1849; Poor inquiry, 219 [35], H.C. 1836, xxxiv, 645.

31 Lindsay Proudfoot and Dianne Hall, 'Points of departure: remittance emigration from south-west Ulster to New South Wales in the later nineteenth century' in International Review of Social History, i:2 (Aug. 2005), 263. 
32 The Nation, 20 Feb. 1847.

33 W.T., 16 July 1853.

34 George Birmingham, The Lighter Side of Irish Life (London, 1911), p. 205.

35 Dublin Record, 7 May 1838; D.D.A., Cullen papers, 41/2/IV/44, letter from Thomas Grant, London to Cullen, 19 Apr. [c. 1853]; B.N.L., 17 Apr. 1887; W. Daunt, 'Correspondence' in Irish Ecclesiastical Gazette (Mar. 1889), 243; Cecil J. Houston and William J. Smyth, The Orange Order in Nineteenthcentury Ontario: A Study in Institutional Cultural Transfer (Toronto, 1977), p. 13; Donald M. MacRaild, Faith, Fraternity and Fighting: The Orange Order and Irish Migrants in England, c.1850-1920 (Liverpool, 2005), pp. 304-6; David Fitzpatrick, 'Exporting brotherhood: Orangeism in South Australia' in Enda Delaney \& Donald M. MacRaild (eds), Irish Migration, Networks and Ethnic Identities since 1750 (Abingdon, 2007), p. 132. On Methodist use of this system see Taggart, Irish in World Methodism, p. 46.

36 The Witness, 6 Jan. 1882.

37 F.J., 3 Sept. 1852.

38 D.W. Cahill, Fourth Letter from the Rev. D. W. Cahill, D.D. to the Small Tenant Farmers, Tradesmen, and Labouring Classes of Ireland (Dublin, 1860), p. 4.

39 Clarke, My Visit to Distressed Ireland, pp. 104-5.

40 M. F. Cusack, The Nun of Kenmare: an Autobiography (Boston, 1889), p. 244.

41 U.N.D.A., Blanc papers, V-5-c-A.L.S-2pp.-4tp-\{2\}, letter from Fr John Spain to Bishop Anthony Blanc, 21 Jan. 1845; U.N.D.A., McFarland papers, I-1-b-A.L.S.-2pp.-12mo.-2, letter from Fr John Ryan to Bishop Francis P. McFarland, 4 Mar. 1865. See also Ruth-Ann Harris and Donald M. Jacobs (eds), The Search for Missing Friends: Irish Immigrant Advertisements placed in the Boston Pilot (Boston, 1989).

42 Fitzpatrick, 'Emigration, 1801-70', pp. 600-3.

43 Devon commission Part ii, p. 959 [616], H.C. 1845, xx, 965; Report of the select committee on outrages (Ireland); together with the proceedings of the committee, minutes of evidence, appendix and index, p. 295, H.C. 1852 (438), xiv, 313. Henceforth cited as Select committee on outrages. Mairead Reynolds, A History of the Irish Post Office (Dublin, 1983), p. 82. A Freeman's Journal correspondent observed that letters were usually sent to the priest or 'in a few instances' the landlord; F.J., 8 Aug. 1851.

44 M. A. Curtis, 'John and the Famine' in Irish Monthly, xxxix:45 (1911), 108. 45 Second report on state of poor, p. 396, H.C. 1830 (654), vii, 572; Report on colonisation, p. 248, H.L. 1847 (737-II), vi, 265.

46 F.J., 27 Dec. 1877; John Brown, Jacob: A Sermon on Emigration (London, 1865), p. 22; An Irishman, Poor Paddy's Cabin; or, Slavery in Ireland: A True Representation of Facts and Characters (Dublin, 1853), p. 146; Report on the state of Ireland, p. 429, H.C. 1825 (129), viii, 443. 
47 'A. McC', 'The America letter' in Irish Penny Journal, i:23 (Dec. 1840), 179. 48 Schrier, Ireland and the American Emigration, pp. 105-28; Sylvester Malone, Tenant Wrong, illustrated in a Nutshell; or, A History of Kilkee in relation to Landlordism during the Last Seven Years (Dublin, 1867), p. 13.

49 Poor inquiry, 314 [35], H.C. 1836, xxxiv, 740; Ibid., 356 [35], H.C. 1836, xxxiv, 782; Devon commission, Part ii, 616 [616], H.C. 1845, xx, 622; Ibid., 334 [616], H.C. 1845, xx, 340; Ibid., 288 [616], H.C. 1845, xx, 246.

50 H. D. Inglis, A Journey throughout Ireland in the Spring, Summer and Autumn of 1834 (2 vols, London, 1835), i, p. 346.

51 Reviews of Inglis's book highlighted this point, and there are many later allusions to it as evidence of a Catholic affection for the parson over the priest. Anon., 'Ireland in 1834' in Dublin University Magazine, v:25 (Jan. 1835), 9; Anon., 'Ireland in 1834' in Christian Examiner and Church of Ireland Magazine, iv:40 (Jan. 1835), 40; 'Art', 'New reformation in Ireland' in Quarterly Review, xci:181 (June 1852), 71; Abraham Hume, Results of the Irish Census of 1861, with a Special Reference to the Condition of the Church in Ireland (London, 1864), p. 36. The Belfast News Letter, however, acknowledged the central role of the priest in the remittance system. B.N.L., 15 Sept. 1851.

52 Select committee on outrages, p. 354, H.C. 1852 (438), xiv, 373.

53 Morning Chronicle, 15 July 1850; B.N.L., 12 Jan. 1852; F.J., 27 May 1851; Report from the select committee on passengers' act; with the proceedings of the committee, minutes of evidence, appendix, and index, p. 303, H.C. 1851 (632), xix, 344 [henceforth cited as Report on passengers' act]; Oliver MacDonagh, A Pattern of Government Growth 1800-60. The Passenger Acts and their Enforcement (London, 1961) p. 189; Robert James Scally, The End of Hidden Ireland: Rebellion, Famine, and Emigration (Oxford, 1996), pp. 184-216.

54 Oliver MacDonagh, 'Emigration and the state, 1833-55: An essay in administrative history' in Transactions of the Royal Historical Society, v (1955), 133-59.

55 Foster (mentioned above) and de Vere, a Limerick baronet's son, were separately instrumental in exposing the appalling on-board conditions which transatlantic emigrants often faced. P.R.O.N.I., Foster of Glyde papers, D3618/D/4/9, Newspaper cutting of a letter from Foster, Jan. 1851; First report of the select committee of the House of Lords on colonisation from Ireland; together with the minutes of evidence, pp. 45-8, H.L. 1847-48 (415), xvii, 49-52. Chisholm, a navy wife, worked tirelessly to encourage and protect emigrants from the UK to Australia, earning her the soubriquet 'the emigrant's friend'. Joanna Bogle, Caroline Chisholm: The Emigrant's Friend (Leominster, 1993). Townsend, an Irish rector's daughter, founded the Girl's Friendly Society, which opened an emigration department to aid females in 1885. Acheson, History of the Church 
of Ireland, p. 215; Luddy, Women \& Philanthropy, p. 60. O’Brien's work is discussed below.

56 The Nation, 25 Sept. 1852; Adolphe Perraud, Ireland under English Rule (Dublin, 1864), p. 238; The Hibernian Bible Society vowed to put a bible in the hands of all departing emigrants: 'the Word of God as our parting and last gift'. B.N.L., 2 Aug. 1842.

57 I.C.R.A., Cullen papers, CUL/270, letter from J. Murphy to Cullen, 7 May 1836; CUL/900, letter from Murphy to Cullen, 22 Apr. 1844. This was a particular problem as single men were not legally to be berthed separately until the 1852 Passengers Act. Terry Coleman, Passage to America: A History of Emigrants from Great Britain and Ireland to America in the Mid-Nineteenth Century (London, 1972), p. 112.

58 Scally also records a (probably Methodist) clergyman giving a final sermon on a ship docked in the Mersey suggesting such blessings were reasonably common. Scally, End of Hidden Ireland, pp. 184-5; see also James Buck, The Forget-me-not, or, Last Hours on the Mersey: A Memorial of Religious Services on Board Australian Emigrant Ships Sailing from the Mersey during the years 1854, 1855, 1856, and 1857 (Liverpool, 1857); Report on passengers' act, p. 228, H.C. 1851 (632), xix, 271.

59 Anon., Hibernicus; or, Memoirs of an Irishman, now in America (Pittsburgh, 1828), p. 143. MacDonagh, Pattern of Government Growth, pp. 204-5.

60 Herman Melville, Redburn: His First Voyage (London, 1849), p. 217.

61 First report from the select committee on emigrant ships; with the minutes of evidence taken before them, p. 172, H.C. 1854 (163), xiii, 176; Jonathan Simpson, Annals of My Life, Labours and Travels (Belfast, 1895), p. 128.

62 Catholic Telegraph, 26 Jan. 1861.

63 Robert Louis Stevenson, The Amateur Emigrant from the Clyde to Sandy Hook (London, 1895), p. 19.

64 P.R.O.N.I., Bates papers, D1414/2, Diary [of William Bates of Strabane] kept on a voyage from Glasgow to Australia Jan.-Mar. 1858; A cabin passenger [Robert Whyte], The Ocean Plague: or, A Voyage to Quebec in an Irish Emigrant Vessel (Boston, 1848), p. 31.

65 Central Archives, St Paul of the Cross Retreat, Mount Argus, Dublin, Devine papers, Fr Pius Devine, 'The adventures and misadventures of a jolly beggar', 1872-1875 (CD-ROM version courtesy of archivist).

66 Perraud, Ireland, p. 242.

67 B.N.L., 27 May 1859.

68 The Tablet, 16 Apr. 1853; Marianne Elliott, The Catholics of Ulster: A History (London, 2001), p. 338.

69 D.D.A., Cullen papers, 45/3/File IX/13, letter from Bartholomew Woodlock to Cullen, 28 Jan. 1859.

70 Michael B. Buckley, Diary of a Tour in America ed. Kate Buckley (Dublin, c. 1870), p. 11. 
71 James K. Strain, The Story of a Visit to America: A Lecture (Belfast, 1871), p. 8.

72 Anon., 'Report of the committee appointed to consider the church's practical work in relation to the care of emigrants' in Randall T. Davidson, The Lambeth Conferences of 1867, 1878, and 1888 (London, 1896), p. 318.

73 This fund was soon exhausted. The S.P.C.K. later took up the work in a very limited fashion. Anon., The Church of England in the Colonies: A Lecture (Colchester, 1851), p. 32; Anon., Summary Account of the Society for the Propagation of the Gospel in Foreign Parts (London, 1851); Anon., 'Report of the committee on the care of emigrants', pp. 316-19; Irish Ecclesiastical Gazette (Feb. 1888), p. 141; H. P. Thompson, Into all Lands: The History of the Society for the Propagation of the Gospel in Foreign Parts 1701-1950 (London, 1951), p. 153.

74 The Catholic priest and novelist Richard O'Brien - likely channelling his own experience of transatlantic travel - wrote of priests doing just that. Richard Baptist O'Brien, The D'Altons of Crag: A story of '48 \& '49 (Dublin, 1882), pp. 132-3; Richard Baptist O’Brien, Jack Hazlitt (Dublin, 1874), p. 98.

75 MacDonagh, Pattern of Government Growth, pp. 195-6.

76 David MacKenzie, The Emigrants' Guide or Ten Years' Practical Experience in Australia (London, 1845), p. 257.

77 C. F. Pascoe, Two Hundred Years of the S.P.G.: An Historical Account of the Society for the Propagation of the Gospel in Foreign Parts 1701-1900 Vol. II (London, 1901), p. 819; Anon., 'Report of the committee on the care of emigrants', pp. 315-18; Anon., 'Church emigrants' in Irish Ecclesiastical Gazette (Mar. 1889), p. 243; B.N.L., 9 Dec. 1891.

78 Minutes of the Proceedings of the General Assembly of the Presbyterian Church in Ireland (henceforth cited as M.G.A.) (1894), p. 788.

79 M.G.A. (1898), p. 561.

80 New York Times, 5 Jan. 1860; B.N.L., 13 Dec. 1859.

81 Ibid.

82 Banner of Ulster, 2 Feb. 1860.

83 A report on Cooke's departure from Belfast in May 1860 recorded that he had helped 'hundreds' of emigrants at a rate of 'twelve or fourteen' per day. Why the office closed is not explained. B.N.L., 8 May 1860.

84 MacDonagh, 'Clergy and emigration' p. 301; Report on passengers' act, p. 438, H.C. 1851 (632), xix, 480.

85 Belfast Mercury, 17 Apr. 1851; F.J., 28 Jan. 1853.

86 Anon., Second Report of the Emigrant Protection Society (Dublin, 1851), p. 7.

87 Diner, Erin's Daughters, p. xiv.

88 O'Connell, 'Charlotte Grace O'Brien', pp. 231-62; Deirdre M. Moloney, American Catholic Lay Groups and Transatlantic Social Reform in the Progressive Era (Chapel Hill, 2002), p. 95. 
89 This followed the abortive efforts of the Nun of Kenmare to involve herself in setting up a corresponding mission in New York - thwarted, as she explained in her remarkable, score-settling autobiography, by a New York priest. Cusack, Nun of Kenmare, pp. 401-2.

90 Maureen Murphy, 'Charlotte Grace O'Brien and the Mission of Our Lady of the Rosary for the Protection of Irish Immigrant Girls' in Mid-America, lxxiv:3 (1992), 261.

91 A.D.A., Logue Papers, Box 2 D.W. 2, Patrick McCool, Circular for private circulation, 24 Feb. 1893.

92 C.D.A., Croke Papers, 1890/5: microfilm, N.L.I., p. 6010-13, letter from Croke to Riordan, 1890; Anon., 'Protection for immigrants in New York' in I.E.R., 3rd ser., v (June 1884), 401-2; A.D.A., Logue Papers, Box 2 D.W. 2, letter from Patrick McCool to D. McCrea, Dec. 1893; A.D.A., Logue Papers, Box 2 D.W. 2, letter from McCool to Cardinal Michael Logue, 12 Dec. 1896; A.D.A., Logue Papers, Box 2 D.W. 2, letter from McCool to Logue, 12 Mar. 1897.

93 On the more general point, see Dympna McLoughlin, 'Information Flows and Irish Emigration: The Image of America in Ireland 1820-1870: A Study of Parliamentary Papers, Newspapers, Pamphlets and Emigrants' Lore' (MA dissertation, St Patrick's College, Maynooth, 1983).

94 The clergyman's propensity (and suitability) to write emigrant handbooks is also suggested by the name of one English Methodist minister's guide to salvation: Jeremiah Dodsworth, The Better Land; Or The Christian Emigrant's Guide to Heaven (London, 1853).

95 Maclise, The Dominion of Canada, p. 3.

96 See Martin Doyle [Wiliam Hickey], Hints on Emigration to Upper Canada (London, 1831), p. vi; Daniel Cahill, Important Letter from the Rev. Dr Cahill to the Small Farmers, Tradesmen, and Labourers of Ireland (Dublin, 1860), p. 7; P[atrick]. Dunne, The Emigrant's Guide to Queensland and the other Australian Colonies (Dublin, 1863), p. 3; Stephen Byrne, Irish Emigration to the United States: What it has been and what it is (New York, 1873), p. 3.

97 On similar sentiments in the first Irish emigration guide, see Kerby A. Miller, 'Revd James MacSparran's America dissected (1753): eighteenthcentury emigration and constructions of 'Irishness" in History Ireland, xi:4 (Winter 2003), 17-22; Miller et al., Irish Immigrants in the Land of Canaan, pp. 19, 59.

98 Methodist advice seems to have been similar in character. Taggart, Irish in World Methodism, p. 46.

99 See Oliver MacDonagh, 'Emigration during the famine' in R. Dudley Edwards and T. Desmond Williams (eds), The Great Famine Studies in Irish History, 1845-52 (Dublin, 1956), p. 384; David Noel Doyle, 'The Irish in Australia and the United States: some comparisons, 1800-1939' in 
I.E.S.H., xvi (1989), 82; David Noel Doyle, 'The Irish as urban pioneers in the United States, 1850-1870' in Journal of American Ethnic History, x:1-2 (Fall 1990-Winter 1991), 36-59; Lawrence J. McCaffrey, 'The Catholic and urban profile of Irish America' in Irish Review, 14 (Autumn 1993), 1-9.

100 Alexander J. Peyton, The Emigrant's Friend or Hints on Emigration to the United States of America, addressed to the People of Ireland (Cork, 1853), p. 36; D. W. Cahill, Important Letter from the Rev. D. W. Cahill, D. D. to the Small Tenant Farmers, Tradesmen, and Labourers of Ireland (Dublin, 1860), p. 4.

101 The description comes from John R. McCleery, Emigration Letters on Canada by a Presbyterian Clergyman Late returned from that Country (Belfast, 1874), p. 6.

102 Doyle, Hints, p. 14, p. 70.

103 MacKenzie, The Emigrants' Guide, p. 274.

104 Dunne, The Emigrant's Guide to Queensland, p. 27; John O'Hanlon, The Irish Emigrant's Guide for the United States (Dublin, 1851), pp. 159-60; Peyton, Emigrant's Friend, p. 29.

105 Byrne, Irish Emigration, p. 56; Stephen Byrne, 'Irish-American colonies' in Catholic World, xxxii:189 (1880), 346-53; John Lancaster Spalding, The Religious Mission of the Irish People and Catholic Colonisation (New York, 1880).

106 Henry J. Browne, 'Archbishop Hughes and western colonisation' in Catholic Historical Review, xxxvi:3 (Oct. 1950), 257-85; Leonard R. Riforgiato, 'Bishop Timon, Archbishop John Hughes, and Irish colonisation: A clash of episcopal views on the future of the Irish and the Catholic Church in America' in William Pencak, Selma Berrol and Randal M. Miller (eds), Immigration to New York (Philadelphia, 1991), pp. 27-55. As both Browne and Riforgiato point out, Hughes also had more selfish and personal reasons for opposing - successfully - western colonisation.

107 O'Hanlon, Irish Emigrant's Guide, pp. 103-4; D. W. Cahill, Important Letter... to the Small Farmers, p. 6.

108 Southern Star, 2 Mar. 1901.

109 MacDonagh, 'Clergy and emigration' pp. 296-301.

110 Maynooth Commission: Report of Her Majesty's commissioners appointed to inquire into the management and government of the college of Maynooth, Part I. Report and appendix, 113 [1896-I], H.C. 1854-5, xxii, 479.

$111 \mathrm{Jim}$ Rees, A Farewell to Famine (Arklow, 1994), p. 54.

112 FJ., 12 Jan. 1849, 2 May 1849, 5 Dec. 1849; The Nation, 8 Dec. 1849.

113 I.C.R.A., Cullen papers, CUL/1658, letter from Maher to Cullen, 13 Oct. 1848.

114 F.J., 4 May 1849. 
115 I.C.R.A., Cullen papers, CUL/1740, letter from Miley to Cullen, 4 May 1849. See also pages $\left.197-9{ }^{*}\right]$.

116 Ibid., CUL/1747, letter from Thos Cullen to P. Cullen, 1 June 1849.

117 F.J., 26 Nov. 1849, 24 Dec. 1849.

118 F.J., 28 Jan. 1850.

119 F.J., 4 June 1850; Andrew McMahon, 'The diocese of Dromore, past and present' available at www.lisburn.com/books/dromore-diocese/parishseapatrick.html. (Accessed 20 Jan. 2008); E. Campbell, Aghaderg. Some Historical Notes (Newry, 1938), p. 12.

120 F.J., 5 July 1845.

121 F.J., 19 Oct. 1850.

122 It is possible that a draft letter in Daniel Murray's papers is a response either to this proposed project or to Doran's, as it also references the Carlow movement. Either way, Murray lent his approval. D.D.A., Murray papers, 34/3, Draft statement from Murray re colonisation, no date.

123 Limerick Reporter and Tipperary Vindicator, 18 July 1851; The AngloCelt, 8 May 1851.

124 See pages 149-51.

125 The Anglo-Celt, 19 Aug. 1852; Select committee on outrages, p. 356, H.C. 1852 (438), xiv, 375; U.N.D.A, Purcell papers, II-4-k - A.L.S. - 3pp. 8vo. - $\{2\}$, letter from Fr William Purcell, to Bishop John Baptist Purcell, Cincinnati, Ohio, 22 May 1849. On Presbyterians, see Jean Stephenson, Scotch-Irish Migration to South Carolina, 1772 (Rev. William Martin and his Five Shiploads of Settlers) (Washington, 1971), pp. 25-6; One traveller encountered a dissenting minister contemplating this path as late as 1836. Baptist Wriothesley Noel, Notes of a Short Tour through the Midland Counties of Ireland in the Summer of 1836, with Observations on the Condition of the Peasantry (London, 1837), pp. 68-9.

126 Owen Dudley Edwards, 'The Irish priest in North America' in W. S. Sheils and Diana Wood (eds), The Churches, Ireland and the Irish: Papers read at the 1987 Summer Meeting and the 1988 Winter Meeting of the Ecclesiastical History Society (London, 1989), p. 317.

127 The Nation, 20 Aug. 1864.

128 The Nation, 10 July 1880. See also The Nation, 19 June 1880, 3 July 1880, 17 July 1880 . For a treatment of the Nugent scheme see Gerard Moran, "In search of the promised land': The Connemara colonisation scheme to Minnesota, 1880' in Éire-Ireland, xxxi:3-4 (Fall-Winter 1996), 130-49.

129 'Pat' [P.D. Kenny], Economics for Irishmen (Dublin, 1906), pp. 5-7; Southern Star, 7 June 1902; Westmeath Examiner, 1 Nov. 1902; Southern Star, 18 May 1895; Meath Chronicle, 1 June 1901; James McFadden, P.P., The Agrarian Struggle in Gweedore: With Letters on Railway Extension in Donegal (Londonderry, 1889), p. 143; The Anglo-Celt, 9 Feb. 1901; Liam Kennedy, 'The early response of the Irish Catholic clergy 
to the co-operative movement' in I.H.S., xxi:81 (Mar. 1978), 55-74. The connection between 'buying Irish' and arresting emigration could be painted in explicit terms: one Sligo shirt manufacturer placed a newspaper puff piece for his products under the heading 'Emigration, and how to stop it'. John Strachan and Clare Nally, Advertising, Literature and Print Culture in Ireland, 1891-1922 (London, 2012), p. 54. 


\section{'Scattered abroad, as sheep having no shepherd': the pastoral responses of the Irish churches to emigration ${ }^{1}$}

From an Irish clergyman's point of view, by far the worst of the iniquities facing migrants was the perceived threat to their faith. While for rhetorical reasons anti-emigration diatribes tended to highlight any wilful oppression - real or imagined - inhibiting the freedom to express one's religion, it was more mundane limits on the ability to practise it which were of most pressing import. Reports of nativist attacks on churches in the United States, for example, may have prompted 'gasconade, froth, foam and fury' in the Irish Catholic press, but the churches that had yet to be built were the real barriers to incoming migrants' religious participation. ${ }^{2}$ Immigrants of all denominations and in all rural destinations could find themselves at a considerable remove from the ministrations of their church, while those who migrated to cities might be among thousands of parishioners under the auspices of one over-stretched cleric. ${ }^{3}$ Evidently more clergy were needed, and until a body of 'native' ministers could be cultivated - relatively late in the day in many instances - the infant churches of the New World looked to the Old World to supply them. This chapter will explore the elements of this call, the readiness of the home churches to heed it, and the effectiveness of their responses.

Before 1815, spiritual efforts on behalf of Irish emigrants were uneven. Although eighteenth-century Presbyterian emigrants were sometimes accompanied by their pastors, the extent of this phenomenon, as Patrick Griffin has shown, can be exaggerated. ${ }^{4}$ There were certainly a few 'cult heroes' such as James McGregor of Aghadowey, who regarded themselves as leading latter-day Israelites out of oppression and into a land of relative freedom, but, as Kerby Miller has argued, there were also those who admitted to emigrating for essentially careerist reasons. Isaac Taylor of Ardstraw, for one, left owing to 
'the want of necessary support' from his congregation. ${ }^{5}$ Consequently, while over a third of clergy in the pre-1750 American Presbyterian Church were Irish-born, after that date, with increasing economic expansion in Ulster, and a resultant greater supply of decent clerical livings, the emigration of clergy abated. ${ }^{6}$ The need for them among emigrants did not abate, however. Griffin notes that in the 1750 s 'settlers in the Shenandoah Valley pleaded with Irish Presbyterian Church officials to send ministers and help in organising congregations in the scramble to bring order to frontier chaos', yet there seems to have been great difficulty in procuring such well into the next century. ${ }^{7}$

Irish Catholic emigrants of the same period were at an even greater disadvantage. The eighty-eight diocesan priests in the American Catholic Church in 1820 were ostensibly enough to attend to the estimated 160,000 Catholics then in the country, but most Catholics outside of larger towns and cities struggled to gain access to the church, and there was already an influx underway of Catholic immigrants from Ireland (and other European countries) which threatened any notional ratio. ${ }^{8}$ The Catholic Association recognised that such a problem existed in 1824 , when its committee resolved to spend $£ 5,000$ a year on procuring 'a sufficient number of priests' for the 'daily increasing' Catholic population of the United States. ${ }^{9}$ It is not clear, however, that the 'Catholic rent' ever paid for any clergy for emigrant communities, and one historian has deemed it merely an aspiration. ${ }^{10}$

Irish Anglicans who emigrated before 1815 were the best served as far as spiritual matters were concerned, benefitting from an organisation that was specifically dedicated to sending clergy to their destinations. The Society for the Propagation of the Gospel in Foreign Parts (S.P.G.) was founded in London in 1701 with the aim of 'promoting Christian Religion in our Foreign Plantations'. In its early years that meant, in practice, providing clergy to UK emigrants. ${ }^{11}$ An Irish branch was established in 1714, and went on to provide several ministers for the North American colonies. ${ }^{12}$ As with the Presbyterian Church, many of these missionaries left for want of opportunities at home: most 'were from among the excessive numbers of poorer clergy with little or no expectation of ever escaping from the poverty at the bottom of the church's essentially class-determined structure. ${ }^{13}$ That need not impugn the value of their work, as W. J. Marshall has noted, but it also implies that any improvement, or perceived improvement, 
in opportunities at home would have lessened the number of clergy available to emigrant communities. Indeed, there was a $25 \%$ increase in the number of benefices in the Church of Ireland between 1787 and 1832, a factor which helped ensure that, by the early decades of the nineteenth century, the S.P.G., including its Irish auxiliary, was moribund and awaiting revival. ${ }^{14}$

With the sesquicentenary of the society's formation approaching, revival came. In its train came the establishment of the Colonial Church and School Society, the emigrant-related offshoot of the more evangelical Anglican Hibernian Church Missionary Society. At around the same time, in 1848, the Presbyterian Church founded its own Colonial Mission. Meanwhile the Catholic Church had seen the establishment of an Irish branch of the Paris-based Association for the Propagation of the Faith (A.P.F.) in 1838, and of All Hallows College of Missionary Education in Dublin in 1842. Therefore, while the notion that mass emigration from Ireland began in the 1840s is certainly outmoded, it would seem that the formal, organised involvement of the Irish churches in the religious care of diaspora communities was largely a mid-nineteenth century phenomenon. Before then, for most Irish emigrants, it was an ambition realised only occasionally and sometimes almost incidentally.

There were several spurs to this concert of new and renewed activity, but the pleas of the destination churches loomed large. These were often the corollary to the kind of anti-emigration warnings detailed in the previous chapter. If the loss of emigrants to the church could not be avoided by arresting their departures, such commentators implied, it should be prevented by ensuring an adequate supply of clergy to emigrant destinations. ${ }^{15}$ This point particularly exercised Bishop John England, whose conclusion that any leakage of Catholics could be blamed on 'the absence of a clergy sufficiently numerous and properly qualified for the missions of the United States', prompted him to make several requests for clergy from his native Ireland. ${ }^{16}$ In an 1823 letter, England urged Daniel O'Connell to use his influence with the Irish hierarchy to procure 'five good priests' for his vast diocese. His request was most likely behind the Catholic Association's abortive efforts in that direction. ${ }^{17}$ The emphasis on 'good' was pointed since, as England's biographer has noted, 'During the first decades of American Catholic life it cannot be held that the Irish hierarchy showed any anxiety to protect the young church of the United States from the evil of unworthy priests. ${ }^{18}$ In England's judicious phrase, it was 'those who 
had the least hopes in Europe', among them scandal-hit 'wandering clerics', who normally made it across the Atlantic. ${ }^{19}$ Thus as late as 1843, overseas bishops, many of them Irish-born, still had to travel to Ireland personally in order to persuade young seminarians of quality to commit themselves to their charge. ${ }^{20}$

The Irish Protestant churches were subject to similar demands. In 1834, Ballymena's Robert Boyd wrote to Henry Cooke from Upper Canada

Let my ministerial brethren of the Synod of Ulster remember that immense multitudes of these dear immortal souls that once sat under their ministry, have now hung their harps upon the high cedars and sturdy oaks of Canada [...] I ask the ministers of Ireland, who among them will come and take these harps down, and again teach their dear countrymen to sing the wonders of redeeming love in this strange land? ${ }^{21}$

Calls of a similar sentiment, if not quite the same eloquence, came from all over the New World. A Pittsburgh clergyman requested 'young and healthy ministers, who are willing to endure hardships as good soldiers of Jesus Christ', while 'Episcopos' informed readers of the Belfast evangelical magazine the Christian Freeman that the Bishop of Ohio was on a visit to the United Kingdom in search of volunteers for his diocese. ${ }^{22}$ The Scottish Presbyterian minister John Dunmore Lang, famed splitter of the New South Wales church, was another who visited Ulster in search of clergy, although his efforts were characteristically not without controversy. ${ }^{23}$

Crucially, these requests were buttressed by the testimony of emigrants themselves. ${ }^{24}$ Letters from migrants of all denominations detailed a lack of, and a desire for, appropriate ministrations. Even on the relatively well-developed east coast of America, many found themselves at a considerable distance from a church or ministers of their own creed. Patrick Fitzgerald, a Catholic originally from Co. Tipperary, explained in a letter from New York State in 1846:

This village contains about 2,500 inhabitants. Here there are Baptists, Presbyterians, Methodists, and Episcopalians all having meeting houses but no Catholic church and not any nearer than Rochester between 30 and 35 miles. I was down there about 6 weeks ago. I left here Saturday night and got back Monday morning about 5 o'clock. [...] So you see if I go to hear mass I have to go a long ways to hear it. ${ }^{25}$ 
Fitzgerald's story must have been at once typical and unusual: of the many who found themselves in his situation, it seems likely that few would have had the time or ability to make such a long journey to church on a regular basis. His sister Eliza, a domestic servant normally based in New York City, had a similar problem attending Mass while summering with her employers upstate. She thought this 'the greatest difficulty in this country but we should not forget our confidence in Divine Providence and the blessed hopes of a Glorious immortality in a world to come. ${ }^{26}$ Perhaps that confidence explains her later decision to relocate to Mobile, Alabama, where wages were higher but Catholic churches and priests - certainly of Irish extraction - may well have been less readily accessible. ${ }^{27}$

The obviously devout Fitzgerald siblings had something of a head start. Where an effort needed to be made to practise their religion, they were willing and able to make it. Another Catholic emigrant writing from New York State, Arthur Quin, asserted unsympathetically that, contrary to what some thought, 'it is our own fault if we don't attend our duty as we can attend it as well here as we can at home. ${ }^{28}$ Yet other Catholics placed in the same and often worse positions simply fell into indifference, or, perhaps harder for those in the home church to hear, converted to other faiths. The Catholic Bishop of Little Rock, writing privately to Ireland in the mid-1840s, noted that he had recently visited families in the farthest reaches of his diocese who had not seen a priest for twenty-five or thirty years, in which the parents or grandparents had been Irish and Catholic but for want of ministry the subsequent generations had fallen away. He baptised some, but others had long since joined more accessible Protestant churches. ${ }^{29}$ Similar experiences were reported from other large sees with scattered populations. ${ }^{30}$ But all was not lost. The reception priests often reported from those who had not seen a priest for some time suggested a ready audience for their ministrations. Visiting Maine in 1855, Fr James Donnelly was met by a frenzy. 'Poor people!' he wrote in his diary, 'How sad to see so many and so good without a Pastor! crushing and pushing for confession, [they] broke 2 panes of glass. Well [they] didn't pull down the house. ${ }^{31}$

Letters from Protestant emigrants in North America and Australia suggested that the absence of a church of their own sect within reach sent them even more readily into other churches. ${ }^{32}$ Gamble Crawford, who wrote to his brother from Ohio in 1860, was quite unsentimental about joining a Baptist congregation. 
I had a letter from the Revd Ray of Buchnaw stating my character and standing as a member extending me the privilege of uniting with any denomination or church of christians to which I should feel inclined to attach myself, this I have done[.] about a year since [I] united with the Baptist church of Richfield, their doctrines are much the same as the presbyterians all the difference is in the ordinance of Baptism [...] I have examined the scriptures on this point to my satisfaction. ${ }^{33}$

Tyrone's James Smyth wrote from Canada: 'I go to Methodist church I don't see any difference none of these ones would go to the Methodist if there was a Presbyterian church here but there is none nearer than Essex. ${ }^{34}$ Later, when the couple had evidently moved to Essex, James's wife was still inclined towards Methodism:

I attend the Methodist Sunday School here as the girl here goes and I go along. I would go to the Presbyterian but Jim don't go to Sunday School so I wouldn't go alone. Jim \& I went to the Presby. church this morning not very many attends. The Methodists has the majority here. [...] Jim was mad because I went to the Methodist twice since I came up here he says I should go to my own but there were two [strange?] ministers to preach in the Methodist so I thought I would go \& hear them. The Presbyterian minister that they have here is just like a drone bee there seems to be no life in his preaching at all. ${ }^{35}$

Other Presbyterian correspondents were less enthusiastic about having to attend alternative churches. Mary Adams, writing from Arkansas, told her former pastor that her family's distance from their church of choice meant that 'we must either live in our unprotected state entirely dependent on the will of others, or take a step which would for a time disconnect us with the church. [...] I beg my dear Sir you will give me your Advice how to see in this dark path. ${ }^{36}$ Mary Ann Blair, a Belfast woman who settled in Georgia, wrote rather indifferently to her aunt in 1847: 'you will think it strange when I inform you that I have not been to church in four years I mean a Presbyterian church I take my family and go occasionally to the Baptist and Methodist. ${ }^{37}$ Yet John Henry, a Coleraine man who settled in Kansas, and Robert McElderry, who addressed his Ballymoney relatives from Virginia, stand out as unusual for not joining any church and awaiting the establishment of Presbyterian congregations in their own districts. ${ }^{38}$

There were plenty, however, who agreed with Mary Smyth that those Presbyterian ministers available were not up to standard. Henry Coulter dismissively described the clergy of his local presbytery in New Brunswick to Rev. William Moreland of Co. Down: 'They 
come on very middlingly; as between external foibles, and internal jealousies of one another, they are easily seen through. ${ }^{39}$ Andrew Greenlees in Ottawa blamed for this 'the Eastern folks' who 'thinks anything will do the barbarians in the west and send on few that is capable of doing any good. ${ }^{40}$ Many correspondents therefore appealed directly to the home church for good ministers. Alex McLeod wrote to William Stavely: 'I envy you in Ireland and envy be without benevolence, for the humble of prime men that adorn your church. [...] I regret that some of your young men do not venture hither. I think a man of talents would do more good to the general cause of America than there.41 Later he implored 'Can you not send us an honest enterprising Hybernian? [...] we have need of help. [...] Oh, for a few good volunteers from Europe - good soldiers of the Cross of Christ!' ${ }^{42}$

These pleas were common to all denominations. Letters collected and published by Rev. William Hickey, and by a Dublin rector, Thomas Radcliff, detail Church of Ireland emigrants earnestly seeking Irish ministers. 'J. and M. T__ wrote to their parents from Yarmouth, Nova Scotia, 'We should be extremely happy if there were a meeting near us [...] I hope you will make up your minds to come, and bring with you a number of truly religious people, and among them an humble preacher. ${ }^{33}$ Radcliff's daughter-in-law told him they saw no acceptable clergymen, only 'preachers, once in a while; and then they sing so, really I am sometimes in roars of laughter at them'. Her husband confirmed that 'clergymen are in great demand'. Radcliff's other son had a novel solution related to Church of Ireland reform: 'We hear that in Ireland you are striking off ten bishops; I wish you could send some of them to us - we have much occasion for them. ${ }^{44}$ In a similar vein, the correspondence of the Kirkpatrick family amongst whom were not only lay emigrants but also Anglican ministers based in Dublin, Ulster and Canada - continually emphasised the extent of 'the wide field there is for the exertions of a zealous clergyman in [Canada]. ${ }^{45}$

Catholic priest Michael Buckley, meanwhile, noted that for many Irish Catholic emigrants, the desire for a priest from home went even further: 'The Irish are never content with any priest except one of their own, and they go so far in this desire that they prefer a priest from their own part of the country to any other'. In illustration, Buckley relayed the story of a Corkwoman whose husband had died in New York. Asked if he had had a priest to comfort him in death she replied cryptically, 'he had and he hadn't. The priest who adminis- 
tered the last rites being a 'Far-down' or Ulsterman, she could not be certain that his blessing counted. ${ }^{46}$ Not all emigrants could afford to be quite so geographically particular, but there was a reasonably clear consensus that 'the Irish people must and will have the Irish priest'. ${ }^{47}$ As one Canadian correspondent put it: 'Those born here are not as much esteemed by the people, as the children of Erin. No matter how gifted or how exemplary they be. ${ }^{48}$ Other European-born priests were no more welcome; they were 'foggy Things who can not speak English and are a laughing stock to [Irish-]Americans. ${ }^{49}$

Of course, as Arthur Quin noted, the failure of emigrants to practise their religion was not always about a lack of access to clergy. Even in larger North American cities, correspondents confirmed, there were many who simply rejected religion. Henry Neill, writing in 1839 from Louisville, Kentucky, to his father in Co. Down, verified that for all the churches in the city, 'not more than two thirds of the population attend any church or religion at all. ${ }^{50}$ Maggie Black writing from Chicago, noted that 'There are a great many non church goers in the city $[. .$.$] too many spend the day in driving "baseball" \& other$ questionable ways. ${ }^{51}$ To that extent, the religious freedom of the New World could have negative outcomes. There may have been room for all creeds, but as the Irish-American cleric 'Peregrinus' observed, in language often echoed by other commentators, it also meant that 'the atmosphere $[\ldots]$ is impregnated with the spirit of "no religion". 52 Immigrants were at liberty to ignore their church, change it, or even start their own. Michael Buckley was told when he questioned the religious fate of second generation immigrants that there was, 'Great freedom of religion - freedom to all [...] every man may have a view of religion different from another, and start a theological theory, and open a church, and appoint a minister of his own. ${ }^{53}$ This backsliding and deviation merely drove home the need for more clergy. As Peregrinus concluded:

Much would be accomplished if the clergy of Ireland once felt the full amount of responsibility they have in this matter. It may be thought that if they do their duty to their people at home, the Irish clergy are not bound to provide for the peculiar dangers that beset those who leave their own country. But emigration is now too important a fact to be ignored by any Irish priest who inquires into his duty to his people. ${ }^{54}$

It was understood, therefore, both by emigrants themselves and the infant churches in their new countries that the home churches bore 
a responsibility - by some reckonings, the primary responsibility towards the maintenance of migrant religion. We should now consider whether this interpretation was accepted by the Irish churches, if they acted upon it, and whether they were they successful.

It is important, firstly, to determine whether and to what extent the Irish churches themselves felt responsible for the safe-guarding of emigrants' religious welfare once abroad. Most accepted the reports of apostasy and indifference at face value. The wrongness of his calculations notwithstanding, the testimony of a figure like Bishop England understandably held immense weight. As one priest argued pro hominem: 'that Dr England should note with sorrow, as he has done, the falling-off of the children of Irish emigrants in America from the faith, is, as I have remarked, the best evidence of the truth of this lamentable fact. ${ }^{55}$ Consequently, there was, as has been seen, a genuine anxiety among Irish clergy that those who left their congregations were risking their chances of salvation. Much as this handwringing went on, however, there is an obvious distinction between accepting and regretting that a phenomenon is taking place, and conceding that one bears any accountability for it, or any duty to reverse or lessen its effects. Nevertheless, for a variety of reasons, both practical and sentimental, the Irish churches seemed prepared to admit at least partial responsibility for meeting the declared spiritual needs of their departed brethren.

First among these reasons was a sense of history. Presbyterians, for example, were acutely conscious that their Plantation ancestors had initially relied on the Church of Scotland to supply their ministers, and the comparison with those now leaving Ireland was not lost on them. ${ }^{56}$ All the churches, however, took pride in those Irish clergy who had gone on to found their sister churches in North America. It was well known that many of the pioneers of Presbyterianism in Colonial America, Francis Makemie and Gilbert Tennent among them, as well as the first Anglican bishop in the empire, Charles Inglis of Nova Scotia, were Irish-born, while the first Catholic bishop in the United States, Baltimore's John Carroll, was of Irish parentage. These and other high profile Irish religious figures were reminders that previous generations of emigrants had not been neglected by the Irish churches. Many clergy, both Protestant and Catholic, delved even further into the past. Irish monks between the fifth and eighth centuries had spread Christianity - Roman or non-Roman, depending upon the claimant's allegiance - all over Europe, and should act as an 
inspiration to the modern cleric. ${ }^{57}$ Tied in with this reading of the past, of course, was a very particular view of the present: the perception that emigration represented the enactment of a providential mission to spread the faith (explored in further detail in Chapters Four and Five). The many clergy who bought into such theories could not, in good conscience, then deny their ministerial support to emigrants.

A further motivation to attend to the religious needs of emigrants was the parallel development of the foreign missionary impulse. This affected each Irish communion differently, and on significantly different time scales. However, as some of the emerging historiography of Irish missions indicates, mass emigration and the move to provide spiritually for emigrants were frequently precursors to 'foreign missions' as they are generally understood today, i.e. the evangelisation of non-Christians. ${ }^{58}$ This could be simply communicating to young Irish clergymen that service abroad was an option, or by directly bringing them, into contact with indigenous populations as pastors to emigrant communities. Regardless, over time, and certainly by the end of the nineteenth century, the greater exoticism and glamour of 'missions of discovery', as distinct from 'missions of recovery', were well established amongst all denominations. ${ }^{59}$ Despite that, to a core of individuals within each church throughout the century, it seemed unreasonable to expend energy on converting 'heathens' while swathes of emigrants born into the faith were reportedly being lost. The philosophy of George Selwyn, the first Anglican Bishop of New Zealand, of building up the colonial churches as missionary churches' was appealing, but if it was to work, it meant, as he told a meeting in Armagh, that, "The duty devolves upon you of making provision, to the best of your ability, for the spiritual wants of your fellow countrymen who come to us. ${ }^{60}$

There were also more instinctive and emotional reasons for Irish clergy to respond positively to the pleas of emigrants and their new churches. For many, simple ties of humanity, nationality and kinship bound them to do so. 'Millions of our fellow-creatures, seated in darkness, and in the shadow of death, anxiously look towards Ireland, and earnestly call upon us to have pity on them,' wrote one Catholic priest. ${ }^{61}$ 'It is', claimed a Presbyterian minister, 'ours to supply the spiritual wants of our expatriated countrymen. [...] Though they are gone from us, they are still of us [...] they are our brethren still, and we are bound to love and succour them.62 The Presbyterian Magazine asked readers whether such people were not 'our brethren, our 
kinsmen, according to the flesh - those who sat at the same mother's knee with us, and shared our youthful sorts around the same household hearth?' and were they not, therefore, deserving of aid. ${ }^{63}$

This affective reasoning had a more prosaic counterpart. For some clergy, it seems clear that a recognition had simply formed that a problem existed, and that the sending churches were as yet the only actors in any position to address it. Emigrants themselves, of whatever class, were taken to be largely helpless in the early years of their migration. The words of Samuel Hinds in relation to Church of Ireland incomers in the colonies rang true for all:

Emigrants in a new settlement have generally no more than enough means to provide for their bodily wants and existence. Necessity is the cause of emigration. Who then cares for the spiritual welfare of these men? What is the channel through which the provision comes to the members of our Church? ${ }^{64}$

In answer, Hinds determined, it could not always be through the receiving churches alone. As it was understood, they had all the problems of under-resourcing and under-staffing that came with being in their relative infancy, while the home churches increasingly had a surfeit of trained personnel. There seemed to be an obvious single solution to this dual problem. Accordingly, for each of the Irish churches, a combination of the above motives meant that a sense of duty prevailed, and efforts were made by individuals and organisations within the churches to ensure that their emigrating co-religionists stayed within the fold.

The range of institutions which began to meet the growing demand for migrant clergy from the 1840s onward were not insignificant endeavours, but historians have paid surprisingly little attention to them. Most of the literature relating to them can be labelled as insider chronicles - what Patrick Comerford has described in the Church of Ireland context as 'partial approaches [which] often border on hagiography [...] written for [and by] supporters and members of the agencies. ${ }^{65}$ They are often based on extensive research and represent a good starting point for anyone curious about the basic facts of missionary efforts on behalf of Irish emigrants, but, as Patrick O'Farrell has sharply observed, 'The marvellous achievements of Irish missionary endeavour, and the eternal indebtedness of other countries to that ministry, spiritual dynamic and personal self-sacrifice, cannot signal the end point of evaluation.66 The remainder of this chapter 
aims to draw out some of the common problems and deficiencies, as well as the motivations and the achievements connected with these disparate, but nonetheless comparable endeavours.

The precise genesis of each church's emigrant mission deserves attention. The Irish Catholic hierarchy began contemplating the matter in 1832 when Bishop England, on a visit to Ireland, suggested that American dioceses might annually receive surplus ordinands from Maynooth and Carlow seminaries. These were men whom Irish bishops had declined to appoint for a lack of parochial vacancies, and who generally ended up offering their services to the English mission instead.$^{67}$ Bishop England considered this mooted deal to be rather a coup, but his attempts to sell it to a still ethnically divided American hierarchy failed, one colleague relaying 'the suspicion with which every measure emanating from Bishop England was viewed. ${ }^{6}$ It seems unlikely that it would, in any case, have provided the continuous stream of clergy which England anticipated, and which was increasingly needed. ${ }^{69}$ Indeed, priests did not leave Maynooth for the Foreign Missions until 1838, and two years later, having sent forty candidates abroad, the Dean of the College was convinced that, "We must get a seminary in Ireland for foreign missions. ${ }^{70}$

This had been on the hierarchy's agenda for some time. William Ullathorne, vicar-general of New South Wales, noted that in 1837 'the Irish Prelacy was seriously thinking of establishing a college for educating priests for the English colonies and foreign settlements, and the Primate, Archbishop Crolly, asked me to draw up a scheme of the probable numbers of priests that might be annually required. I drew up a paper of the kind and presented it to him. ${ }^{71}$ No action was taken by the bishops, however, until 1842. In February of that year, the Archbishop of Cashel, Michael Slattery, searching for a purpose for his diocese's recently opened but directionless seminary in Thurles, suggested to the Association for the Propagation of the Faith that it might serve as a foreign missionary college. ${ }^{72}$ Undeterred by that committee's preference for a Dublin location, Slattery set about acquiring a rescript from Rome to allow the establishment of a missionary department, which was duly granted in July. ${ }^{73}$ Both Bartholomew Crotty, the Bishop of Cloyne and Ross, and the Bishop of Cork, John Murphy, offered Slattery their nominal support. ${ }^{74}$ Crotty pointed out, however, that much as he wished to see such a college in Thurles, Slattery may have been 'too late'. Crotty had heard that premises and land had already been purchased near Dublin for the same purpose. 
The premises in question were Drumcondra House, which, oddly enough, had originally been built by Marmaduke Coghill, founder of the S.P.G. in Ireland. In September 1842 it re-opened its doors as the Missionary College of All Hallows. This was the result not of action from bishops or the A.P.F., but of the almost singular efforts of its founding president, John Hand. A young priest from a relatively modest background, Hand had been inspired to try and meet the demand for clergy for the increasing emigrant stream by, firstly, the establishment of the Irish branch of the A.P.F. four years earlier and, secondly, the 1838 publication of Bishop England's injunction regarding Catholic migrant 'leakage' in its Annals. The story of how he realised this, collecting the necessary funds by personally traversing the countryside in a horse and cart, reads like a founding myth when given prominence in later heroic biographies of Hand. ${ }^{75}$ However, it is essentially true, and, as we will see, serves as a neat encapsulation of the college's rather isolated position within the church over the next fifty years.

All that being said, it ought to be acknowledged that Hand did not act entirely alone. In David Moriarty and Bartholomew Woodlock he had competent and ultimately well-connected fellow professors (and successors as President of the college), and in Archbishop Murray of Dublin and Bishop John Cantwell of Meath he had some, largely personal, hierarchical patronage. It was Cantwell, prelate of Hand's native Meath who had secured him his place in Maynooth, his poor background notwithstanding, and Murray who had appointed him to his first position as a deacon shortly before his ordination. ${ }^{76}$ Although Hand had acquired permission directly from Rome to establish the college, was endeavouring to fulfil a need for missionary clergy that was widely acknowledged to exist, and had attracted students from the beginning, he still struggled to have his efforts recognised by the wider church. All but Murray and Cantwell ignored a circular Hand sent to the bishops in December 1840 proposing the college's foundation, and his annual reports to the hierarchy went unanswered until 1846, when the bishops merely resolved, 'That the assembled prelates feel much gratified by the progress of the Missionary College of All Hallows and that they wish the establishment continued success. ${ }^{77}$ This brief and belated acknowledgement came too late for the man whose work it commended, however: shortly before, Hand had died of tuberculosis, which implies that sympathy for the late priest, rather than simple admiration for his institution, lay behind the resolution. 
Nonetheless, episcopal recognition did allow the college to begin fundraising on a national scale, and advertisements to this end began appearing regularly in the Catholic press. ${ }^{78}$ From that point the college's survival, albeit still outside of the mainstream of the church, seemed more or less assured.

Given that there was clearly an acceptance in principle that a missionary training college was needed, preferably in Dublin, what did the bishops' reticence on All Hallows signify? A number of points must be considered. The first is that Hand was not the only enthusiastic 'man on a mission'. In 1839 another obscure cleric, John Foley, had founded St Mary's College for the foreign missions in Youghal, Co. Cork. This institution seemed, despite the apparent support of $\mathrm{Dr}$ Foran, Bishop of Waterford and Lismore, to operate under the radar for some time, and when Tobias Kirby, then the deputy rector of the Irish College in Rome, visited the establishment in September 1841, he reported back to Cullen in Rome that, 'It is a surprising business. No one knows how Mr Foley has done it. But the work is done; a noble establishment is really in operation [...] four zealous priests teaching volunteers for the good work. ${ }^{79}$ There was some support for Foley's efforts: Cullen and Cardinal Fransoni (Prefect of the Congregation for the Propagation of the Faith in Rome) together contributed $£ 70$ to the college on foot of Kirby's positive assessment. ${ }^{80}$

However, when Cullen himself inquired about the college on a trip to Ireland in July 1842, he heard a very different story. 'I fear,' he told Kirby, 'Fr Foley's establishment is not going so well as you imagine’:

I saw a most excellent priest who had been lately there and who is anxious for the success of the enterprise - but still he gave me information which makes me fear that Fr Foley is not over prudent. He has established a penitentiary for disgraced females within a few yards of his college - a most dangerous experiment - he has also received students of very dubious character from distant parts of Ireland, without ever asking for a testimonial of their conduct from Priest or Bishop. This will certainly destroy the name of his college. Rev. Mr Forbes is also, I am informed, about to leave, in which case I believe he has no one remaining fit to teach any thing to their students. [...] If all these things be true, there can be little reason to hope. ${ }^{81}$

Indeed there was none; Foley died in 1844, 'considerably in debt' with Cullen among those seeking in vain for a return of his donation - and the college did not survive him. ${ }^{82}$ 
Yet Cullen had been no more hopeful for Hand's endeavour. He and Kirby may, according to one historian of All Hallows, have been instrumental in helping to smooth Hand's path with Propaganda Fide, enabling him to get Papal permission to set up the institution, but, Cullen claimed, 'He will fail, I suppose, for the want of fit men to manage the undertaking.83 This appraisal came despite Murray's spirited defence of Hand in an earlier letter to Cullen:

I perceive good $\mathrm{Mr}$ Hand has succeeded to his heart's content [...] you thought he had no energy. You can hardly have a notion of the energy and perseverance of that man. If his positive success be equal to his energy it will be great indeed. ${ }^{84}$

There is a sense, however, that even Murray had his doubts about Hand, and he understood why other church authorities may have held back from lending him support. 'The council of the Propagation of the Faith have declined,' he told Cullen in June, 'to do anything for the new College except to provide outfit for the young missionaries after they have completed their studies and to contribute to their support when engaged in their missionary labours. Perhaps after all they have acted wisely in proceeding with caution until they see how the thing will work. ${ }^{85}$

In this last sentence lies the rub. For all that the hierarchy may have recognised the need for more missionary clergy, they were slow to initiate the work necessary to provide them, and were, moreover, suspicious - perhaps rightly - of those necessarily zealous and assertive individuals who stepped into the breach. One of Hand's biographers plausibly suggests that the Maynooth funding controversy was preoccupying the bishops and preventing their acting on a matter over which there was general agreement, while 'others in less responsible positions were not reduced to inactivity. ${ }^{86}$ 'Less responsible' individuals had to prove themselves before gaining the trust of the hierarchy, however, and with it the means to establish their colleges permanently. Fr Foley failed in this, but while Hand (at least in death) and his successors were more successful, the initial lack of hierarchical approval had long-term repercussions. As a consequence, All Hallows occupied a curious administrative grey area. Dr Crotty's early warning that any missionary college should be committed to government under the bishops or to a congregation of secular priests, rather than relying on one 'isolated individual clergyman' was not heeded until 1892; indeed, not even the Holy See was mentioned 
in All Hallows' constitution. ${ }^{87}$ This uncertain positioning, as Kevin Condon points out, stored up internal disciplinary problems for later, but it might also be added that it contributed to a far from exemplary religious provision for the many Irish Catholic emigrants. ${ }^{88}$

In contrast to All Hallows, the Colonial Mission of the Presbyterian Church was conceived and founded as a central part of its church's wide-ranging missionary programme. This, as it turned out, was both a blessing and a curse, but it appeared at the time to be a logical progression. The eighteenth-century antecedents of Presbyterian missions to emigrants were often random in nature, relying on the happenstance of the individual ministers' personal migration decisions. By the $1830 \mathrm{~s}$ it became clear that this self-generating process had all but ceased, even as emigration from Ulster congregations, increasingly directed towards the empire, remained significant. Henry Cooke's Orthodox Presbyterian was vocal in tackling this anomaly. Its third number, announcing the departure of Hope Waddell, Edinburgh-based but Monaghan-born, for Jamaica, set the tone when it asked 'How long shall he be the only missionary from amongst the Presbyterians of Ulster?' ${ }^{89}$ In the ensuing years, such admonitions routinely included reference to the 'thousands of our fellow-countrymen' who had emigrated and now looked to Ireland to provide them with ministers:

[I]f all our Clergymen and Elders were to rouse themselves to a sense of their duty - if they were to use all their endeavours to excite a spirit of Missions in their Parishes, we should soon have funds wherewith to establish a number of Clergymen in our Colonies, where from the multitudes of emigrants from Ireland and Scotland their labours are most anxiously required. ${ }^{90}$

Moves in this direction were slower than the authors of these sentiments hoped, however, and those clergy who did rouse themselves during the rest of the decade followed Waddell in aligning with the Church of Scotland, first through the Scottish Missionary Society, and after 1836 through the Kirk Colonial Mission. ${ }^{91}$ Of this latter scheme Don Chambers has noted both the internal power struggles which delayed its establishment and the external pressures which eventually made it inevitable, ${ }^{92}$ and it is possible to see similar, though perhaps less pronounced, dynamics at work within the Irish church. While the evangelicals represented in the Orthodox Presbyterian pushed for more co-operation with colonial churches, they were met with a certain apathy. In 1831 a delegation sent to Ulster by the Scottish 
Missionary Society expressed disappointment at the lack of interest in their cause from ministers and congregations alike. ${ }^{93}$ External influences were also powerful. The calls from emigrants themselves and the correspondence from clergy abroad were, as noted, compounded by visits from senior foreign church figures seeking ministers, including John Dunmore Lang.

It seemed, however, that as long as a few Irish clergy could fulfil a sense of missionary duty towards emigrants under a Scottish banner, or could regard the thriving Home Mission as a means of indoctrinating future emigrants, ${ }^{94}$ that the establishment of a distinct Irish Colonial Mission could remain on the back-burner. The Synod of Ulster may have expressed the hope of following the Mother church's example in founding four separate mission schemes, including a Colonial Mission, but with the formation of the General Assembly in 1840, only a Foreign Mission, focused on 'heathen' conversions in India, was immediately formed. ${ }^{95}$ The following year did witness the appointment of a Colonial Committee, but this was a mere formalisation of the arrangements already in place, in that it co-operated closely with the Scottish Colonial Mission and continued to allow delegations from Scotland to fundraise in Ulster. ${ }^{96}$

The Scottish connection was finally broken when, somewhat ironically, a Dundee Free Church clergyman offered the General Assembly news of 'spiritual destitution' among Ulster emigrants in Canada which shocked it into action. In 1846 P. L. Millar 'pressed upon the Assembly the necessity of encouraging her licentiates and students to devote themselves to the religious instruction of that people. ${ }^{97}$ Although Millar did not appear to specify how that was to be achieved, and he may, indeed, have simply been making a bid on behalf of his own newly constituted sect for any Ulster missionaries who volunteered for colonial service, an exploratory committee appointed to assess the question came to the conclusion that the Assembly needed its own Colonial Mission. ${ }^{98}$ This came into being in August 1848 under the convenorship of William McClure of Derry, whose opening address in that capacity referred to 'the General Assembly having had its attention forcibly directed to the religious destitution of emigrants. ${ }^{99}$ This would prove to be an unconsciously prophetic statement, as 'forcibly directing attention' to the religious needs of emigrants might easily have served as McClure's new job description.

Although ostensibly the oldest of all the Irish church bodies providing clergy to emigrant communities, the S.P.G. had fallen into decline 
in Ireland by the time each of the above institutions was being created. An attempt made to rejuvenate the Society in Belfast in 1840 proved abortive. The clergy of Down and Connor convened a meeting which was addressed by the well-known evangelical preacher Hugh McNeile and by Dr Russell of the London S.P.G. Though it was resolved to found a diocesan branch, this appears to have existed in name only until 1848. ${ }^{100}$ In September of that year, Dr Mant, the Bishop of Down and Connor, chaired a similar, if sparser, gathering which nonetheless had more success. ${ }^{101}$ From that date, with the attentive input of Mant's successor, Robert Knox, a reasonably regular programme of activity was kept up, including an annual meeting and appeal for donations. ${ }^{102}$ The diocese of Armagh, meanwhile, had raced ahead in reconstituting S.P.G. branches; between 1840 and 1846, eleven parochial associations were formed. ${ }^{103}$ Movement was also afoot in the diocese of Dublin. The Dublin University branch of the S.P.G. had evidently remained potent enough to occasionally encourage students to offer their services to the parent society in London, yet weak enough to lend the Irish auxiliary neither the kind of national profile that would increase such vocations, nor the donations necessary to fund them. ${ }^{104}$ So it was that Samuel Hinds, a chaplain to Richard Whately, gave two speeches in Trinity College on the need for 'increased exertion', in 1846 and 1847, years of rapidly growing emigration. Subsequently published in pamphlet form, Hinds' words seem to have been influential; he left Dublin for Carlisle and afterward the see of Norwich in 1848 , but the Dublin and Kildare auxiliary to the S.P.G. was active from at least 1849, under the presidency of Archbishop Whately. ${ }^{105}$

The other major strand of the Anglican missionary movement, the Church Missionary Society, or as its Irish branch, founded in 1814, was known, the Hibernian Church Missionary Society, regarded emigrants' religious aid as at best a secondary concern. Although it sent missionaries to areas of Irish settlement, including Canada and New Zealand, they concentrated there, as elsewhere, on the conversion of the native peoples. ${ }^{106}$ In part, this reflected its origins as the avowedly evangelical counterpoint to the more high-church S.P.G., which many in the eighteenth century (and perhaps after) felt had concentrated on preserving the faith of colonial settlers to the detriment of spreading it among non-Christians. Nonetheless, elements of the Hibernian Church Missionary Society did take part in the mid-century renaissance of emigrant missionary activity. By means of a bewildering number of name changes and a merger of societies 
concentrating on North America and Australia, the Colonial Church and School Society came into being in 1851, with Irish branches formed first in Belfast then Dublin by $1854 .{ }^{107}$ Its goal was to provide missionary clergy and teachers to British emigrants, and although it was not officially linked to the Church Missionary Society, there was an overlap in both membership and philosophy. As a later, postname-change report pointedly noted, 'The Church Missionary Society has no more powerful auxiliary than the Colonial and Continental Church Society. Their principles are identical. If, therefore, adversaries tauntingly ask - "While eager for the conversion of the heathen, how do you provide for your own?" - we answer by pointing to our Society. ${ }^{108}$ The reference to taunting adversaries hints that the Church of Ireland's efforts on behalf of emigrants' spiritual welfare would be no more straightforward than those of the other Irish churches.

Detailing these awakenings of missionary activity in relation to Irish emigrants primarily serves to illustrate that they did not occur in isolation. Certainly, as noted, such missions must be considered firstly as responses to the requests from the diasporas concerned and from the destination churches. They were also part of an international picture, spurred on by similar, sister movements across the North Channel in the case of the Presbyterians, in London for the Church of Ireland, and in France as far as the Catholic Church was concerned. ${ }^{109}$ Finally, the increased and increasing emigration before, during, and in the immediate aftermath of the Famine forcibly drove home a point with which each institution had already begun coming to terms. It is also the case, however, that the efforts of the Irish churches did not happen without reference to each other. All of the above missionary endeavours began within a few years of each other, from the foundation of All Hallows in 1842, to that of the Colonial Church and School Society in 1854. Notably, the S.P.G.'s branch in Belfast was reconstituted in the very shadows of another church's efforts in the same city. This might seem mere chronological coincidence, were it not that the inter-denominational - if hardly ecumenical - influences were often given voice. From the beginning, the language used at public meetings of emigrant missionary societies, and in the literature they issued, was frequently suffused with a sense of religious competition which indicated a continuing awareness - however illusory it may sometimes have been - of the other Irish churches' equivalent activities. The abiding suspicion of all concerned was that the other denominations were racing ahead in the peopling of emigrant destinations 
with clergy. A speaker at the founding meeting of the Belfast S.P.G. in 1848, for example, 'adverted to the efforts of the Roman Catholic hierarchy to propagate the errors of Popery in the colonies and showed how needful it was to be vigilant, in order to counteract the effects thus made. ${ }^{110}$ Six years later, an early meeting of the Colonial Church and School Society, also in Belfast, was told that, "There was not a spot on the face of the earth so priest-ridden as Canada. There were not three miles without a Roman Catholic chapel' and, with regard to Australia, that 'Popery was sending out fifty agents for the one that we send." ${ }^{111}$ Samuel Hinds put it in the most explicit terms: 'Roman Catholic chapels are rising everywhere [...] and Roman Catholic priests are everywhere active and zealous - [...] there is the Kirk, too, and its Presbytery - should we not be provoked to zeal that we be not left behind in the race of sacred rivalry?' ${ }^{112}$

Supporters of the Presbyterian Colonial Mission were just as conscious of the urgency of ensuring that 'Rome [...] shall not be established in this fast rising empire. ${ }^{113}$ One missionary in Queensland warned McClure that the redoubtable Catholic bishop in the state, James Quinn, was receiving 'vessel after vessel' of priests from the south of Ireland. 'Let Protestants be up and stirring, he begged, 'or this fine and fertile country will soon be wrested from their hands, and over its fair fields supposition and idolatry will reign. ${ }^{114}$ Presbyterians, too, could display a more even-handed paranoia, also fearfully invoking the missionary efforts of the Anglican Church:

All denominations seem alive to the importance of the colonies and that church will be predominant that can afford the greatest number of talented and devoted Missionaries. The Roman Catholics are sending troops of priests and men. The Church of England is procuring everywhere the erection of new bishoprics, and filling them with men, some of whom are evangelical, and others of a very different spirit. ${ }^{115}$

For the Catholic Church, there was no such confessional subtlety and all Protestant missionary efforts towards settlers in the colonies, and indeed the United States, could be tarred with the same brush; one that was often used at home to apply anti-'souper' rhetoric. There was thus little or no sense that the above-mentioned missions of Protestant churches, whether of Irish origin or otherwise, were devised simply to serve Protestant emigrants. Rather, as the Annual Reports of All Hallows continually alleged, the S.P.G. et al. were bent on 'the destruction of Catholic truth among our exiles.' ${ }^{116}$ They 
formed the vanguard of an 'Anglo-American conspiracy', of a 'crusade' to overthrow the Catholic Church which was driven by 'inexhaustible resources, blind zeal, and the highest official influence. ${ }^{117}$ Such allegations were not entirely without substance, as we will see, but more convincing was the testimony of Catholic bishops abroad, who contrasted their penury with the alleged expenditure of Protestant missions. As the Bishop of Auckland lamented, 'The Protestants in these two respects (in number of Missionaries and in pecuniary means) are far superior to me."118

If all of this poor-mouthing seems somewhat circular - each church being at once better off and worse off than its rivals - it must be remembered that different churches had different strengths depending on the region and the period concerned, and much of the above rhetoric was based on the genuine perceptions of missionary clergy of their relative situations. However, some of these assessments were likely exaggerated in order to convince home churches of the need for further aid. It follows, then, that the sort of competitive rhetoric employed in missionary publications and at missionary meetings served a similar purpose. It was designed not simply as sectarian grandstanding for its own sake, but was calculated to elicit the kind of emotions that would move readers and listeners to donate funds, and prompt worthy clergymen to offer themselves for emigrant missionary service. The success of the latter will be explored, but the issue of how these exploits were funded requires attention first.

Sending clergymen abroad was an expensive business. Although in certain territories, at certain times, there was limited government financial assistance available to colonial churches for the support of clergy, by mid-century most of this support had been discontinued. ${ }^{119}$ Each of the above-named institutions had therefore to fund themselves. The costs involved depended on the nature of the model they operated, but one line of expenditure common to all was the training of personnel. For All Hallows, as a missionary seminary, such costs were obviously central, but for the Presbyterian Church and the Church of Ireland they were hidden, since the mission schemes did not directly pay for their volunteers' education. Nonetheless, if Protestant commentators often lamented emigration for its human capital costs, this was oddly reinforced by sending highly educated ministers to serve overseas. Regardless of the quality of the clergyman (and there were, as we will see, questions surrounding this issue) his training had cost his home church both time and money which 
would not be repaid. Naturally the Irish churches thought about such matters in altruistic terms, if at all, but they were nonetheless financially weakened by this clerical 'brain drain'. That being said, there were more direct funding problems to be confronted, and while each church did so differently, they shared the unfortunate characteristic of frequently falling short of what was necessary or expected.

This was true, above all, of the Presbyterian Colonial Mission. The costs to be met from its budget included the outfit and passage of missionaries, and in certain cases their salary, or a part thereof, for the first few years of their posting. The Mission may also have been subject to further funding requests from colonial congregations until such time as they became self-sufficient. In its first forty years the Mission sent somewhere up to 110 missionaries, so a considerable income was required. ${ }^{120}$ This had to be derived from an annual collection taken in every congregation on a given Sunday, with bequests and subscriptions also coming in year-round. Indeed, this was how all of the missions of the church were supported - from the ground up, with ordinary churchgoers, prompted by their minsters, expected to contribute financially to each. ${ }^{121}$ Monetary support for the Colonial Mission, however, was minimal. The monthly newspaper which documented all the church's missionary endeavours, the Missionary Herald, regularly published the yearly collections from each congregation and for each mission side by side. The following table samples from there the quantities collected for Foreign, Home, Jewish and Colonial Missions from Belfast, the largest Presbytery, for a selection of years:

Table 3.1 Belfast Presbytery donations to Missions (in $£$ sterling)

\begin{tabular}{lcccc}
\hline Year & Foreign & Home & Jewish & Colonial \\
\hline 1850 & 579 & 523 & 265 & 91 \\
1855 & 689 & 398 & 280 & 234 \\
1860 & 833 & 616 & 362 & 291 \\
1865 & 923 & 817 & 411 & 350 \\
1870 & 888 & 377 & 424 & 342 \\
1875 & 1,019 & 436 & 450 & 356 \\
1880 & 931 & 333 & 297 & $271^{*}$ \\
\hline
\end{tabular}

${ }^{\star}$ Note: this is a bi-annual figure 
Some points relating to the table should be explained. Firstly, while it is apparent that the Colonial Mission remained the poor relation in terms of contributions - attracting less than a quarter of the Foreign Mission total - the picture is bleaker than even these bare figures suggest. What is not apparent from the table is that the seeming jump in donations between 1851 and 1863, and the later drop, do not reflect any changed perception of the Colonial Mission, but rather denote its amalgamation with and subsequent splitting from the Continental Mission, in 1856 and 1879 respectively. Moreover, following the split, the Colonial Mission had its annual collection changed to bi-annual, so post-1879 figures must be halved to give the true annual rate. It was suggested hopefully by one minister that this implied that 'gifts should be double what is given to the objects which obtain annual aid', but this does not appear to have got through to congregations. ${ }^{122}$ Therefore, over thirty years after its foundation, the Colonial Mission was attracting barely more congregational funding per annum than it had in its initial years.

To give these meagre amounts some further context, it may be observed that just one request from a single colonial congregation, particularly in the more sparsely populated regions of Western Canada and Australasia, could far outstrip them. Writing from Queensland in 1864, Rev. John Wilson asked that the home church guarantee a $£ 200$ per annum salary for any minister it sent out, with the hope that in as little as three months, the expatriate congregation would provide a sufficient maintenance themselves, all the more readily for not having been bombarded with begging sermons from the newcomer. ${ }^{123}$ For some clergy, financial requests to the convenor were made to avoid destitution rather than mere social embarrassment. Thomas McPherson, a minister in Stratford, New Brunswick asked, obviously reluctantly, for $£ 200$, 'which is not a large sum to you,' towards his congregation's $£ 500$ debt, its church-building fund, and the support of his own ten children. McClure, despite his mission's admirable policy of continuing to fund clergy after their appointment to the colonies when necessary and when possible, was able only to tell McPherson that $£ 250$ had been given to the entire Canadian Home Mission that year and 'a part of this may, probably, be given to Stratford'. ${ }^{124}$

Both McClure and his successors as convenor, David Wilson, James Cargin, and Thomas Hamill, clearly despaired of these straitened circumstances, but beyond impassioned appeals in the press there seemed to be little they could do to improve them. ${ }^{125}$ As early 
as 1852 , McClure had felt compelled to defend the Mission against a creeping apathy:

An impression has gone abroad, in some quarters of the church, that contributions for the Colonial Mission are not expected to be so general and regular as in other cases. This impression is erroneous. The Colonial Mission, it is true, was established at a period somewhat later than the Home, Foreign and Jewish Missions, but it stands upon the same footing with them. ${ }^{126}$

Evidently, this impression was never successfully countered. Year after year, the reports of the Colonial Mission therefore had the same defensive quality, the need to justify its work seeming only to confirm its marginal status. By the end of the 1880s there were even efforts in some quarters to have the mission wound up. The presbytery of Newry unanimously asked the General Assembly in 1889 that no further collections be made on the Colonial Mission's behalf, while there were attempts by some in the Ards presbytery to table a motion to close the mission down on the grounds that 'the colonial churches [...] had grown to be much wealthier churches than theirs. ${ }^{127}$ These moves were beaten back with the usual arguments, but they highlight the precarious nature of the Colonial Mission's existence. ${ }^{128}$

Unsurprisingly, none of this played well with the missionary clergy themselves, who, while they retained sympathy for the convenor, were also considerably disheartened by the level of support offered by their compatriots. James Caldwell, a missionary in Victoria, Australia, was highly critical of the home church's lack of commitment to the religious needs of the colonies, and of Irish congregations' financial contributions to clergy in the colonies. 'I have often been deeply humbled,' he said, 'nay, obliged to blush, over the reports that have reached us of the miserable givings of some of your congregations for the maintenance of those engaged in the noblest and best of work. ${ }^{129}$ Yet the apparently misguided supposition that 'a missionary to the colonies receives at once adequate support from the people to whom he ministers' - true only in Victoria, according to McClure - meant, inevitably, that the Colonial Mission was not well supported and so perhaps not all that it could have been. ${ }^{130}$ The perception of the Ards presbytery in 1890 that colonial churches were increasingly better off than the Irish church forms part of the explanation as to why this was. Certainly, intermittent gold rushes did not help the colonial churches' case with potential benefactors at home, even if, as one minister in New 
Zealand pointed out, prospectors were not exactly 'digging up lumps of gold like potatoes', and, as a minister in Victoria told McClure, this had not actually led to any increase in support for the church. 'The majority', another gold field correspondent noted, 'lives as if there was not a God to call us to account. ${ }^{131}$ All the same, Irish Presbyterians at this later stage could perhaps be forgiven for believing their work had been done in relation to colonial churches. McClure's opening address in 1848 had, after all, emphasised that 'a great recommendation of this mission is that it requires only commencement'; emigrant congregations were intended to become self-sustaining in relatively short order. ${ }^{132}$ Yet there had never been a particular enthusiasm for the Colonial Mission. On its twenty-fifth anniversary, McClure told the General Assembly sadly that 'he did not think [it] had made such an impression on the mind of the church as it ought to do' and for all the 'white unto the harvest' rhetoric - one New Zealand missionary was not alone in asking 'What other of our Missions could show for $£ 1,000$ what you can show for $£ 100$ ?' - the Colonial Mission remained the least supported of all, even as the Foreign Mission went from strength to strength. ${ }^{133}$

The key to this disparity can be gleaned from a doctoral thesis on 'the birth and development of the overseas missions of the Presbyterian Church in Ireland, which contains only one passing reference to the Colonial Mission in its introduction: it was not really a 'foreign mission' - it sought to serve Irish and other Presbyterian emigrants.' ${ }^{134}$ This raises an interesting question as to whether the Colonial Mission can even be strictly considered a mission. By modern definitions, possibly not, and while the most ungenerous response to that question never came fully to the surface during the nineteenth century, an unspoken conflict surely existed. The writer of an article on 'pastoral versus missionary duties' which insisted that 'A Presbyterian family saved in county Clare is as precious as a family converted in Syria' suggested that in a church which had neither the money nor the manpower to do all it would wish, the pastoral duties of the Home Mission were primary and the missionary activity of the Foreign Mission secondary. ${ }^{135}$ This in itself would prove a minority view in the later nineteenth century as missions in China and India became the priority, and the mission to Irish Catholics waned. Meanwhile, the Colonial Mission, which aspired to 'save' families in Canada and Australia, appeared to fall awkwardly between these two stools, serving, in the main, people who were Irish and Presbyterian from 
birth, but doing so in circumstances and on a scale that was comparable to the Foreign Mission. Any underlying idea that the Colonial Mission was 'not really a mission' can therefore only have harmed its standing in a church in which mission was an increasingly powerful principle. ${ }^{136} \mathrm{~A}$ final word on this must go to Rev. P. M. Pollock, who in a series of articles on mission work in Canada sharply outlined though in rather crude terms - what he saw as the reasons for the neglect of the religious needs of emigrant communities:

I often think it is a great pity these poor settlers have neither a pigtail or woolly heads, nor thick lips, a nose jewel, a pagoda, a red tissue paper visiting card, or a paperpocket handkerchief to show in Toronto or Montreal. Unfortunately they are only of English, Irish, or Scotch descent, and cannot claim the sentiment which is lavished on India or Formosa. ${ }^{137}$

It seems reasonable to suppose, in this instance, that what was true in Canada applied equally to Ireland.

The Church of Ireland's missions towards emigrants also had problems attracting donations from the laity, partially as a result of the ecclesiological split which had begun to dominate the wider Anglican Church. The S.P.G., as the longer-established and traditionally highchurch society, had to defend itself against evangelical allegations of Tractarian or Romanist tendencies, prompting protestations from its members in Ireland that no particular ethos ruled, whether high or low church. ${ }^{138}$ For the Irish church, especially, this may have been true. ${ }^{139}$ Yet, while perhaps not quite as riven by the Oxford movement as the Church of England, the auxiliary status of the mission societies meant they could not be isolated from the troubles of the parent organisations. This left two societies with broadly similar aims competing for the support of a relatively small Irish church population, and created a rivalry which may well have damaged both, rather than benefiting either. Although Bishop Knox organised a joint meeting of the S.P.G. and the Church Missionary Society in Belfast in 1859, insisting that 'there is no rivalry existing between them but that holy rivalry of which will do the most good', the tenor of many of the speeches suggested otherwise. ${ }^{140}$ Certainly, neither the S.P.G. nor its evangelical counterpart ever seemed satisfied with their annual collection totals, asserting that they were 'altogether unworthy' of the particular diocese, or 'still far short of the amount that we might reasonably be expected to contribute. ${ }^{141}$ It became routine to blame 'ignorance and 
misconception' of the societies' aims for these shortcomings, Richard Whately even suggesting that in the S.P.G.'s case 'the term "Foreign Parts" is not unlikely to mislead some persons; or at least, to keep out of sight that the main object of the Society is to provide religious instruction and superintendence for our fellow-subjects. ${ }^{3}{ }^{14}$

There was, however, a happier side to auxiliary status which meant that such financial deficits were a matter of less pressing concern to the Church of Ireland societies than they were to the Presbyterian Colonial Mission. While the latter scheme relied largely on congregational collections in Ireland to pay for the missionaries whom it sent out itself, the S.P.G. and the Colonial Church and School Society were in reality little more than cheer-leading adjuncts to far larger (and much richer) entities in London. Clergy of the Church of Ireland who wished to serve emigrant communities abroad, had, like their English counterparts, to go before the societies' respective boards of examiners in London, which assessed their suitability before allowing them to go on the mission. ${ }^{143}$ Therefore, there was a less direct relationship between Irish emigrants, Irish missionaries and Irish fundraising for them in the Anglican Church than was the case in the Presbyterian and Catholic churches.

This is not to suggest that the financial arrangements underpinning the Catholic All Hallows College were by any means straightforward. Like the S.P.G. and Presbyterian Colonial Mission, the college was responsible for the passage and outfit expenses of its missionaries. Unlike its Protestant counterparts, however, it also had to find the funds to educate them, though this was balanced by the fact that All Hallows did not offer financial support to its alumni or their new churches once they had left. It is unlikely it could ever have done so, since its guiding principle over the following decades was expansion, including a physical expansion of its buildings to accommodate ever more students who had to cater for ever more emigrants in ever wider territories. ${ }^{144}$ This, naturally, required a corresponding increase of its financial support, and several avenues were therefore explored. As noted, All Hallows began fundraising nationally after receiving tacit episcopal approval in 1846. The college authorities followed the normal pattern of Catholic charity in the period. Press advertisements, including lists of donations by parish and of large individual subscriptions, were regularly placed, parochial collections were made in Ireland (although these were discontinued in 1863), and funding was sought from overseas. ${ }^{145}$ Collections were 
often organised on the missions by alumni of the college, and in 1854, Dr O'Brien, professor of rhetoric in the college, conducted a wellpublicised lecture tour of England designed to raise funds. ${ }^{146}$ A year later, and again in 1864, William Kelly, a former Christian Brother who was initially employed by the college solely as a collector, went to the United States. ${ }^{147}$ Such tours, as always, had mixed success, and could be limited by the unwillingness of overseas bishops to allow collections in their dioceses, which many of them felt distracted from their own projects. ${ }^{148}$ For All Hallows, these kinds of charity lectures were in any case not without politically-tinged controversy. In 1855, Woodlock was forced to accede to Archbishop Cullen's request that no more public meetings be held to raise money for the college. This was brought on primarily by O'Brien's invitation of Thomas D'arcy McGee to speak in Dublin on All Hallows' behalf - 'likely to be looked on as a political fact' as Cullen warned - but was not unconnected to 'O'Brien's proceedings in England'. As Woodlock acknowledged, 'a good deal of money has been brought into the College during the last year. However, I think it is a great question whether it could not have been collected without quite so much noise little to the purpose. ${ }^{149}$

While all of this activity certainly attracted more money than had Hand's horse and cart odyssey, it was not to be the only source of funding. In fact, the authorities at the college soon realised that collections from the faithful alone would not sustain them. The initial assumption that the A.P.F. would make some contribution, even if only by donating a portion of the sum annually collected on its behalf in Ireland, turned out to be quite misguided. These parochial collections, according to the Annals of the Propagation of the Faith, usually garnered in the region of $£ 6,000-£ 7,000$ before and after the Famine and $£ 3,000-£ 4,000$ during it, but they were transmitted directly to the central fund in Paris. All Hallows was not in line to benefit from the Irish A.P.F. collections. As Kevin Condon explains, the Paris committee had a policy, tied in with the French missionary system, of granting money to missionaries and missionary societies, but never directly to missionary supply colleges, which were usually either government-funded, or attached to the missionary societies. ${ }^{150}$ This did not prevent an on-going and often fractious campaign by All Hallows in favour of the idea, which resulted, during the exceptional circumstances of the Famine, in some small, but vital, concessions for a few years. Government funding was more of a blind alley. In light of the Maynooth grant increase in 1845, both Moriarty and Woodlock 
appealed to the Colonial Office for a subsidy for All Hallows, pointing out that the government was already paying salaries to some Irish priests in the colonies. Aside from one sympathetic official, their pleas fell on deaf ears. ${ }^{151}$ The best they could do was secure a few one-off sponsorships of missionaries' outward journeys, a minor relief which some overseas dioceses were also occasionally prepared to concede. ${ }^{152}$

Indeed, for all these disappointments, the college did have a notable success in its unique arrangement with overseas bishops - the brainchild of Hand - whereby the adopting diocese was asked to pay half of the student missionary's annual college fees. Until 1861, this was $£ 10$ (afterward $£ 15$ ), with the student himself also paying $£ 10$. The system got off to a rocky beginning. An initial round of correspondence sent by Hand in 1842 to bishops in the United States and the colonies offering missionary priests was for the most part either ignored or acknowledged in the negative, many bishops no doubt wondering who this lowly priest was with his unsolicited offers of half-price priests. Contrary to one historian's view, this was not owing to any general pre-Famine lack of demand for missionaries from Ireland, but was a result of the inability of many bishops to come up with the $£ 10$ per capita required. ${ }^{153}$ The bishops of New Orleans, Philadelphia, St Louis and Nashville were among those pleading poverty in 1843-44. ${ }^{154}$ Matters quickly turned around, however, and by $1845-46$, still before the Famine emigration took hold, the college was dealing with multiple requests for its students. ${ }^{155}$

There is some irony that the money the bishops remitted often came ultimately from the A.P.F. in Paris, so that, in a circuitous manner, All Hallows benefited from the monies gathered by the A.P.F. in Irish parishes far more than it might have seemed. ${ }^{156}$ More importantly, Irish emigrants themselves owed a considerable debt to the Association, as an advertisement placed by the Irish branch in 1853 pointed out:

The Society has allocated annually the large sum of thirty thousand pounds to those countries in which most of the Catholics are either Irish, or the children of Irish parents. Many Irish Missionaries, Bishops, and Priests, in foreign lands, have a considerable portion of the expenses of their missions constantly defrayed by this Society. On the prosperity, then, of the institution, the spiritual interests of Irishmen all over the world are very much, and in many places entirely, dependent: and be it therefore always remembered, that whilst contributing to the Association for the Propagation of the Faith, we in Ireland, are receiving a ten-fold return in favour of our own exiled fellow-countrymen. ${ }^{157}$ 
Thus, 'Priests for the emigrants' were paid for from a wide variety of sources. In contrast to the Presbyterian Colonial Mission, collections from the laity were not the only, or even the main source of income. As in the Church of Ireland, however, there existed an external missionary body, to which the Irish church contributed far less than was ultimately expended on its emigrants. Yet, perhaps the factor which most distinguished the Catholic provision of clergy to its emigrants from the corresponding Irish Protestant missions was the significant extent to which the receiving churches and the emigrants themselves directly contributed towards the clergy they asked for, via the half-fee system and foreign collection tours. What the Irish Catholic Church offered its emigrants by way of religious aid, then, was simply personnel, and if anything, financial aid for religious purposes went in the opposite direction.

As noted, students of All Hallows bore a considerable financial burden. Most had to find $£ 10$ towards their fees each year, and several who were not lucky enough to be sponsored by an overseas diocese during their training paid even more. ${ }^{158}$ In return, they were subjected to a notably spartan regime. During the Famine, one American priest wrote to Moriarty sending $£ 3$ to one 'inmate' (an unintentionally telling choice of language) who had complained of having no clothing allowance: the money was to pay a washerwoman to have his outfits cleaned. ${ }^{159}$ Later, Woodlock felt the need to warn a potential student of what to expect, "lest he should find the place rather rough in the beginning. ${ }^{160}$ To some degree this was an inevitable result of the college's financial straits, but there may also been an element of design to such hardship. ${ }^{161}$ Certainly, Woodlock explained the college's 'roughness' in terms of its missionary status, and The Tablet, pondering where best of England or Ireland to locate a missionary college, agreed that 'the willingness to endure the hardships of a foreign mission, to live roughly, to fare coarsely, and to undergo the privation and suffering which accompany the priestly vocation across the ocean, are to be looked for mainly in the poorer of the two countries. ${ }^{162}$ Moreover, during early debates over the foundation of a missionary college, Bishop Crotty, speaking with the killjoy facility of the outsider, stated that he 'would not have either the students or supervisors too highly fed. Such a diet as we had in the Parlour and Refectory of our National College at Maynooth would be a bad preparation for the privations they would have to endure in travelling through the wilds of America or Australia or even through the Highlands of Scotland.' ${ }^{163}$ 
Crotty and The Tablet had a point. Clergy of all denominations had frequently to endure harsh conditions in ministering to emigrants and overseas prelates were wont to warn as much in their correspondence with All Hallows. Prospective missionaries for Texas, according to the Bishop of Galveston, 'must submit to a great many privations', ${ }^{164}$ while the Bishop of Richmond, when requesting six missionaries from Hand in 1845, chose to emphasise the dispersed, tough nature of the work to be done (as well as its scant rewards) to forestall any surprises on arrival:

[They] must expect a life of great labour and fatigue, much exposure to cold, heat and rain, bad roads, very indifferent diet and lodging, but little respect for [their] dignity, few Catholics, little of society and a compensation barely adequate to support [them] in the plainest and most economical manner. [...] I want no priest who does not come fully prepared to enter upon such a charge. ${ }^{165}$

This itinerant life was the lot of many All Hallows alumni, the inevitable result of clerical shortages amid scattered settlements, particularly in the emerging, territorially vast dioceses in the western and southern United States and in the colonies. It meant suffering, as one later All Hallows graduate observed of Australian missionaries, 'the constant fatigue and strain of long sweltering hours in the saddle, the ever present danger of losing their way in the dense, trackless bush with the cheerless prospect of spending the night under the stars, surrounded by the indescribable loneliness of the mysterious primeval forest.'. 166

Some notable feats of endurance resulted. Fr Willie O'Brien is said to have performed 'the most remarkable sick call in Australian history' when he covered 150 miles on horseback in a round trip one Saturday night, returning home in time to say his two Sunday morning Masses in the process. ${ }^{167}$ George Dillon, in New South Wales, told Dr Woodlock that in eight months he had travelled 4,000 miles visiting the scattered Catholic settlers of his diocese. ${ }^{168}$ These duties did become easier as territories progressed. William Hamilton, writing from Florida in 1856 anticipated that 'we have just now commenced to construct railroads in this state, which will render missionary life much more expeditious and comfortable. ${ }^{169}$ Until such infrastructure was in place, however, there was little comfort for many missionaries, and while one All Hallows alumnus claimed that all his travelling was 'healthful and invigorating', and another that his new climate was 
'good and healthy', there were many who succumbed to an early grave as a result of their exertions. ${ }^{170}$ Beyond the anticipated hardships, there were also occasional crises which compounded the difficulties of life on the mission. Certainly, the staff and students of All Hallows were aware of the ultimate sacrifices made by several Irish priests working among the fevered immigrants of Quebec in 1847-48. ${ }^{171}$

Anglican clergy, of course, had also died while tending the sick at Grosse Île, and many Church of Ireland men who volunteered for service to settlers in the colonies were also destined for peripatetic lives covering parishes of considerable geographic extent. ${ }^{172}$ Henry Irwin, or 'Father Pat' as he was known to all, was one such in British Columbia, where he tended to the communities springing up alongside (and building) the railroad. A fellow minister later recorded the wide reach of Pat's mission:

Father Pat did not confine his work to the main line of the C.P.R. [Canada Pacific Railway] but journeyed down the Arrow Lakes, services being held as far south as Nelson, then a mere mining camp. We find, too, that he followed the Columbia from Golden to the Kootenay River, services being recorded at these places. Some six or eight clergy now occupy the territory thus covered, divided into five or six parishes. ${ }^{173}$

This extensive travelling was physically exhausting - at one point Irwin was forced home to Wicklow and the care of his family while he recovered his health - and whatever its rewards, they were not material. In a letter home Irwin described himself sitting down to eat his lunch at the mines: 'a dirty, travelled-looking individual, a poor imitation of a parson, sitting at one side of the log fire; a tin plate with his bacon and beans on it, and his tinney of tea; bread just cooked on the fire in a dirty pan.'. ${ }^{3}$

Another Irish S.P.G. missionary, Edward Synge, was an even more significant pioneer in the Australian colonies, where the Bishop of Sydney charged him with organising church structures in the bush. His efforts led, within a few years, to the foundation of the separate bishopric of Goulbourn. ${ }^{175}$ Again, this was wide-ranging and lonely work; according to one source, 'Equipped with a compass, packhorses, and the barest necessities for travel, it was not an uncommon thing for him to make itinerating journeys in the bush extending over a period of nine months at a time and covering a distance of over five thousand miles. ${ }^{176}$ While there are, in fact, several wildly varying but always impressive estimates of the extent of Synge's labours to be 
found, their difficulty, and the commitment they required, rings out from each. ${ }^{177}$ If such exertions went above and beyond the normal call of duty, the lot of the ordinary colonial clergyman had its own challenges; one Colonial and Continental Church Society missionary was told by his receiving bishop, that 'his post will be an arduous one, he will have to hold three services on Sunday, and travel thirty miles over very bad roads, he will not be able to sit down to a meal till evening, but must eat as he gallops along. ${ }^{178}$

There were equally gruelling and poorly paid assignments for Presbyterian missionaries in the colonies, and equally noble acts of selflessness ensuring they were fulfilled. In 1871, Robert McKinney won praise for his decision to stick with his itinerant mission in New Zealand, turning down, in the process, a settled ministry with a trebled income. A colleague wrote that McKinney felt his mission would not have survived his leaving. ${ }^{179}$ McKinney himself further outlined his reasons for staying put:

The colonial minster is rewarded in the hearty welcome he receives from the isolated settler, in the good that notwithstanding many discouragements, he feels assured he is doing, and, in my case, also, rewarded by the approval which my labours met with from the church of which I am still proud to regard myself as the missionary - the Irish Presbyterian church. ${ }^{180}$

His commitment was even more impressive when one considers that it was a New Zealand missionary magazine which later asserted that 'Colonial ministers, as a general rule, are doubtless the hardest worked clergymen of any in the world. ${ }^{181}$

Another Ulster minister, James Patterson, filled a similar itinerant role in the Australian colony of Victoria in the early 1860s, visiting dispersed communities of 'diggers' who, he suggested, had previously only encountered clergy seeking 'money for baptising and five pounds for marrying' rather than the salvation of the miners' souls. He would, no doubt, have despaired at the idea later communicated to McClure by a correspondent in Victoria that the scattered, poor nature of some congregations in the colony meant, 'There is not at present a single vacancy in the church of Victoria which is really worth anything. ${ }^{182}$ That said, while passionately committed to his missionary work, Patterson was also realistic about the toll it was taking on his health: 'It is still my intention to return home. [...] Three years of this rough work is my contribution to the cause, and I feel convinced the strings 
of my being will wear longer at home than here'. Yet, to Patterson's mind, 'travelling ministers (themselves the Presbytery)' were precisely what was required in the colonies, and he was critical of the home church for sending out clergy with 'settled down notions in their heads, instead of urging them to itinerate in long-neglected places. ${ }^{183}$

These few representative examples demonstrate that within each denomination, the mission to emigrants, no less than mission to non-Christians, could be a deeply felt vocation undertaken despite sometimes ruinous implications for health, lifestyle or finances. As many insider histories and contemporary reports emphasise, that was to be commended, and several of the more industrious Irish clergymen could lay claim to be true 'pioneer priests', extending the structures of their church into previously ignored territory. Nonetheless, as much as receiving bishops, or fellow clergy, or settler congregations might have lauded the zeal of such ministers, they were also unafraid to point out that very many others failed to live up to the same standard.

Allusions to the questionable quality of All Hallows alumni, in particular, are not especially hard to find. The historian Owen Dudley Edwards has observed that, both at home and abroad, general opinion unofficially placed the college in third rank behind the diocesan seminaries, which primarily produced parish priests for the home church, and behind Maynooth, the alma mater of bishops. ${ }^{184}$ Some specific instances of third class (and perhaps even fourth class) candidates do arise in the college's overseas correspondence. These include William Roddy, who, before he was even ordained, was shunted between adoptive prelates on the basis of an unspecified but apparently serious misdemeanour, and an unnamed All Hallows graduate who, according to his bishop, 'had several times become intoxicated, and taking up a chalice from the church, tried to sell it to a silversmith in a city in Maryland. ${ }^{185}$ Some allowance has to be made for their dissolute ilk. Certainly, what Donna Merwick (by way of Graham Greene) calls 'whiskey priests' were an occupational hazard, and there is nothing to suggest that they were the disproportionate preserve of All Hallows or of the missions in general. ${ }^{186}$

That being said, if we are to believe the memoir of one former student, Richard Howley, a different form of rather unpriestly rambunctiousness was tolerated at All Hallows, if not at times encouraged. Writing after the takeover by the Vincentian order - an outcome he described as 'being bullied into line with other institutions' Howley described the college's 'mad youth' in the early 1850s, when 
'a grand freedom of spirit that scorned the machine-press system of the regulation seminary pervaded the whole body, superiors and students.' 'The memory and the mood of '48,' he recalled, 'were alive and burning in those young breasts', creating a 'fervour of nationalism. ${ }^{187}$ This fervour produced the worrying 'noise' that Woodlock had told Cullen the college could do with less of, but it is unclear whether or not it was ever successfully quietened. Dr O'Brien, the teacher of moral theology who was the cause of Cullen's concern, gradually drifted away from the college in the ensuing years, preoccupied with spreading his Catholic Young Men's Societies. ${ }^{188}$ This was not before he had made his mark on some of the students, however. David McRoberts attributes to him the All Hallows men in Scotland who 'seemed more concerned with the grievances of Dark Rosaleen than with the Five Ways of Aquinas. ${ }^{189}$ This was a well-documented problem in the Scottish church, and Ruth-Ann Harris, citing the All Hallows Scotland correspondence, observed an early pattern of professors warning their graduates not to engage in political activities in their adoptive parishes. One 1843 letter urged: 'leave behind your national feelings, try to accommodate to the habits and ideas of the people among whom you have come to live and consider yourselves sent by God to preach the Gospel to Foreign Nations, in place of preaching to their Irish politics. ${ }^{190}$

The very fact that such cautions were deemed necessary speaks of an awareness, even from very early on, that the college was producing politically-minded priests with the potential to cause headaches for their adoptive bishops. It is therefore curious to note that Howley, for one, did not discern any clipping of nationalist wings while he was attending the seminary. He claimed, in fact, that issues of The Nation were regularly the basis of study, that patriotic sing-alongs (led by the teaching staff) were frequent and that Dr Moriarty, then president, 'gave no evidence of disapproval of the national spirit he knew to exist in the college'. Indeed, Moriarty had been an avowed supporter of the Young Ireland movement and remained a lifelong friend to Charles Gavan Duffy through 'trying and troubled times. ${ }^{191}$ He even asked for a dispensation for early ordination of an All Hallows priest so that he might provide a chaplain to the 1848 leaders during their transportation to Australia. ${ }^{192}$ This was in spite of his subsequent reputation, when translated to Kerry, as 'the most Castle-loving of all the bishops on the Irish bench, a description seemingly justified by his infamous condemnation of the Fenians. ${ }^{193}$ That 'unconsidered flight of fancy' 
was obviously a sore point with Howley and his peers and indeed in 1871, when one of Paul Cullen's anti-Fenian pastoral letters was being read aloud in the refectory of All Hallows, those assembled reportedly 'erupted into a noisy demonstration of displeasure', preventing it being finished, an occurrence which Cullen's nephew, Bishop Patrick Moran of Ossory, saw as evidence of 'radical evils' in the college. ${ }^{194}$

The presence of this nationalist spirit was confirmed by another contemporary chronicler of All Hallows, Fr John Curry. A fairly innocuous early draft of his thoughts on the college's founding which preceded Howley's account by a few months avoids any mention of political sentiments among the student body. ${ }^{195}$ However, drawing somewhat on Howley's testimony, Curry's longer study of 1900 delicately speculates:

Whether the superiors of the College were inspired with like feelings (which, I believe, was the case with most of them), or whether they foresaw the advantages this national spirit would confer towards carrying out the work of the missions among Irish exiles, certain it is that they did not discourage, if they did not actively foster it. They did not deem it of obligation, at all events, to strive to convert this band of Irish youth ${ }^{196}$

Curry makes an astute point here, which might perhaps be extended. The unique status of the college as a kind of unofficial religious order producing secular priests who could not be centrally recalled from overseas dioceses in the same way as, say, the Christian Brothers were withdrawn from the diocese of Sydney in the $1850 \mathrm{~s},{ }^{197}$ created internal disciplinary problems which eventually led to the Vincentian takeover in $1892 .{ }^{198}$ Before that occurred, however, the superiors of the college, in harnessing a nationalist spirit and allowing it to flourish, may have sought to create a useful and probably otherwise unobtainable sense of togetherness, a common and fondly remembered bond of community among the students. Advantageous though this might have been, it was not always helpful to send forth priests who might stray into politics in their new homes, hence the advice of one later All Hallows teacher to a missionary to 'forget All Hallows except in your prayers. ${ }^{199}$

This was a very fine line for the college authorities to walk, however, and they may not always have succeeded. Adopting bishops were certainly alert to the problems that priests of ardently nationalist sympathies might present, particularly in the context of a Fenian 
movement which had begun among emigrants in America and was spreading quickly among the diaspora elsewhere. Some complained to the college superiors. In the 1860s Bishop Demers of the diocese of Victoria in Canada undertook to sponsor eight All Hallows students, of whom only two ever settled under his charge. One did go on to become vicar-apostolic, but the other, William Moloney, was 'an extremely outspoken man, [who] was soon infuriating the English [...] with his "sermons" on British "history". A fellow missionary of Belgian origin, who was to succeed to the bishopric, described Moloney as 'God's curse on the diocese of Victoria'. Unsurprisingly, Demers chose not to use All Hallows again. ${ }^{200}$ In a separate context, Archbishop McCloskey of New York despairingly told Patrick Leahy of Cashel that 'most of the clergymen who have come out from Ireland have allowed themselves to be caught in the Fenian trap. ${ }^{201}$

It ought to be noted that Kevin Condon sought to dismiss any sense of nationalist spirit that may have existed in All Hallows, but his efforts are unconvincing. He suggested that Howley's recollections of nationalism in the college were 'coloured by his own prejudice', and that 'the only [member of staff] about whom there was even a suggestion of nationalist feeling was [Fr William] Fortune. ${ }^{202}$ Yet it is abundantly clear that R. B. O'Brien was a fervent nationalist, and Woodlock's suggestion to Cullen that O'Brien was 'against Young Ireland' and that his friendship with D'arcy McGee was simply a personal one, can be seen as an attempt to retain a gifted teacher by way of a (probably) disingenuous denial - O'Brien was even then an anonymous contributor to the Nation ${ }^{203}$ Coupled with the obvious Young Ireland sympathies of Moriarty, this rather confirms Howley's memoir. In addition, Condon noted that the report of the later hostile reaction to Cullen's anti-Fenian letter emerged only because an outsider was present, something which might suggest that similar outbursts of national sentiment often occurred without anybody present to witness them. ${ }^{204}$

Admittedly, as far as emigrants themselves were concerned, this nationalist hue to All Hallows priests need not have been a problem. As Curry suggests, any hint of an advanced nationalism probably even endeared many a missionary priest to his flock. However, in the long run, priests considered troublesome to their bishops in this respect can only have slowed down the spread of the church and impeded its ability to provide pastoral care to emigrants, by exacerbating disputes among prelates of different national outlook or origin, by necessitating parochial transfers and a search for replacement clerics, by 
irking the imperial authorities with whom the Catholic Church often had a mutually beneficial colonial relationship, ${ }^{205}$ and ultimately, as Harris's Scottish correspondent warned against, by preaching politics rather than the Gospel. However, there was a yet more invidious deficiency in many All Hallows-trained priests which impacted much more directly on emigrant communities.

Returning to Owen Dudley Edwards' point, there is certainly ample evidence to support the 'third class' accusation. Sponsoring bishops routinely made subtle and not-so-subtle reference to the poor intellectual capacity and pastoral skills of the priests they had been sent. The Bishop of Dubuque, a diocese which had previously received All Hallows alumni, wrote to request 'good priests' in 1860, feeling obliged to underline 'good' twice. ${ }^{206}$ Others were more to the point. James Bayley writing to Woodlock from Newark declined to adopt one Fr Quinn as he was given to understand that he 'was not very well endowed with brains' and 'a priest on the mission in this country needs all his wits about him. Woodlock obviously tried to persuade him to the contrary, but Bayley had already been burned and he warned 'If Terence Quinn is not superior, in his appearance and manners to Rev. Cornelius O'Reilly, I do not want him. An awkward clownish priest makes a bad impression. ${ }^{207} \mathrm{Bad}$ preaching seems to have been a recurring flaw of migrant Irish clergy. Bishop Walsh of Halifax bluntly informed Moriarty in 1848 that 'Fr Lyons can't preach'. Bishop John Andre of Pittsburgh generalised the point, claiming that many young Irish priests lacked this vital skill, including those from All Hallows. He could, he said, 'scarcely catch a word in ten' and was forced to 'imagine that their mouths were full of meal.' ${ }^{208}$ This had worrying implications, as Walsh noted, as it deprived the people of necessary instruction. Of related concern was poor knowledge of the rituals of the church. The Bishop of Savannah, for one, entreated of the All Hallows superiors that any men intended for his mission be properly acquainted with all ceremonies, relics, and altar arrangements. ${ }^{209}$

All of which suggests a less than complete education on the part of many All Hallows priests. This was often literally the case. So urgent was the apparent need for missionaries that a significant proportion of All Hallows graduates were not technically that, often being ordained by their adopting bishop following a truncated period of training in Drumcondra. This arrangement had mixed reviews. On one hand, the likes of Bishop Celestine of Vincennes suggested that priests would benefit from a longer stay in Drumcondra; on the other, 
Bishop Loras of Dubuque was amongst those pushing for priests to be readied as soon as possible. ${ }^{210}$ There is little doubt where Moriarty stood on the issue in the immediate post-Famine period. It was he who was responsible for greatly increasing the capacity of the college so that the needs of Loras and his fellow bishops could be met, and there is some suggestion that he may have been prepared to sacrifice quality for quantity in doing so. As he later told Woodlock 'I am not afraid of the growing number of students [...] If they have to live in tents I would take a multitude into All Hallows.'. ${ }^{211}$ Whether the resulting priests were up to standard is clearly questionable.

Curry admitted that the shortened course of training was one factor which 'interfered somewhat considerably with [the college's] results. ${ }^{212}$ Moriarty may have come to agree with that assessment. His Allocutions contain some remarkable passages written in 1867 which cast aspersions on clerical education in Ireland compared with that in America and England; an unfavourable contrast he was surely aware of from his All Hallows days. ${ }^{213}$ The other factor Curry cited was related: 'the necessity [...] of admitting students that were not as well trained for college life as was desirable..214 A similar allegation, it must be recalled, had been thrown at Fr Foley's failed college in Youghal, with Cullen suggesting that his students were of dubious character and provenance. Equally, many a sow's ear to silk purse transformation was attempted at All Hallows.

Moriarty himself was aware of this: during his presidency he asserted that the college must ensure that 'the rude and vulgar boy from the country is changed into the saintly priest.'. ${ }^{215}$ The 'rude and vulgar boy' was often, like the founder of the college, from a poorer social background than most of those who found their way to well-fed Maynooth. ${ }^{216}$ Indeed, one historian of the college suggested that All Hallows' intake largely comprised of 'young men who would not otherwise have had the opportunity of being ordained'; those who were either unable to pay fees at Maynooth, or, the corollary must follow, who were of insufficient quality to gain a scholarship there, as Hand himself had. ${ }^{217}$ Condon makes a similar point, declaring that 'The college had its own place within the ecclesiastical framework of the country...it gave an outlet for vocations' - hardly a ringing endorsement of the student body. ${ }^{218}$ A contemporary American contributor to Orestes Brownson's magazine chose to frame the same opinion in less delicate terms: 
They say in Ireland that there is a great difference between the raw material of Maynooth, Carlow, the Irish Houses of Rome and Paris, on the one hand, and that of All Hallows, on the other. The reasons are obvious. All the men fitted for home service want to stay at home, those only volunteering for the foreign brigade who can do no better. ${ }^{219}$

Many Presbyterians appear to have shared this assumption. Indeed, the notion that colonial service was a second-best or even a last-resort career option for ministers seems to have preceded the Colonial Mission and therefore hampered it from the outset. One congregational history, for example, records the removal of a Mr Watson from his ministry in 1836 on account of 'a difficulty that had arisen'. Watson, presumably unable to find a new Irish congregation, decided to emigrate to the colonies for work, where, despite the earlier controversy, 'for several years he was a diligent and successful minister.'20 Problems emerged, however, when such rejected ministers proved to be neither diligent nor successful, and the perception of colonial congregations as a dumping ground for less gifted, or otherwise objectionable pastors was thereby compounded.

Colonial presbyteries bridled at this unofficial assignation of second-class status to their ministries, and were dismayed by the consequent reluctance of clergy of talent to take them up. A campaign was launched on two fronts to combat the problem. Sub-standard clergy were repeatedly and plainly told by correspondents in the Missionary Herald that the colonies would not provide the soft-touch or desperate congregations that they might have hoped would accept them. Dr Burns of the Canadian Home Mission was among the first to assert that, 'Those who would not succeed at home can have little hope of being useful [in Canada]', and warnings of the kind became more explicit as time went on. ${ }^{221}$ A Queensland correspondent told McClure in 1862 that 'It is a great mistake to suppose that men of inferior talents, and whose hopes of success at home have nearly expired, are good enough for the colonies', while six years later, the point having obviously gone unheeded, the same colony's General Assembly stated more emphatically:

We cannot get a supply of ministers from the home churches, nor are those who come in all cases suitable. It is a charming delusion that prevails extensively at home, that a minister who cannot get on there should emigrate to the colonies. It is a delusion which is often rather rudely dispelled when sometimes it is too late. ${ }^{222}$ 
In all of this, the good faith of the Colonial Mission convenor was rarely directly questioned, although the Queensland General Assembly came close in suggesting that 'men of piety, prudence and ability' were not always the ones who found favour with the Colonial Committees. McClure magnanimously acknowledged that the stricture was 'severe but not wholly undeserved,'223 but he was perhaps guilty of an undue harshness on himself. In reality, the convenors of the Colonial Mission were in much the same bind as successive presidents of All Hallows. Good clergymen were needed but were not always available, certainly not in the numbers required, so a choice often had to be made: send a less-than-stellar candidate or send none at all. The former may have all too often seemed the better bet. However, as one clergyman in Victoria, Australia, warned, 'Our vacant congregations prefer to be vacant rather than take any preacher. ${ }^{224}$

McClure and his successors as convenor therefore felt obliged to guard against poor colonial clergy by actively striving to attract the best volunteers to their Mission. Again, although there are occasional references to the convenors speaking to students at Assembly's College 'on the great claims of the colonial field', annual reports and the pages of the Missionary Herald provided the most useful fora for their persuasions. ${ }^{225}$ Young ministers were asked to contemplate 'whether they would not be serving God quite as much by going to the colonies as by remaining with small congregations at home, and the advantages of colonial service over the other foreign missions were also extolled: 'the ministers we send forth do not require to learn new languages, and no lengthened course of training is required'226 The matter was also painted in sacrificial terms for the wider church: 'If we wish to be successful abroad, we must learn to give up some of our most able and efficient ministers.227 Coupled with the kind of crusading rhetoric observed earlier, this might have been expected to capture the imaginations and the commitment of many worthy young preachers. However, McClure continued to report difficulty in finding acceptable missionaries, a function, he was convinced, of colonial service's second-rate reputation. As he told the General Assembly in 1866, 'promising men [are] frequently dissuaded from going out by their brethren.228 He later elaborated:

The impression seems in many quarters to exist that for a young man of first-rate ability to give himself to this department of the church's work, is virtually to throw himself away. Never was there a greater mistake. 
Emigrants are usually among the most enterprising and intelligent portion of the community and are able to appreciate the abilities and work of the most talented ministers. ${ }^{229}$

That may well have been the case, if the commonly expressed idea held true that it was the 'bone and sinew,' 'the cream of the nation,' 'the very flower of the people' who were leaving Ireland. ${ }^{230}$ The Church of Scotland minister David MacKenzie certainly believed that, apostates aside, congregations in Australia were more attentive than any he had known in Europe: 'There is here less yawning, less listlessness, and assuredly less sleeping, than I have often witnessed in my younger days when attending the churches in evangelical Scotland. ${ }^{231}$ One theory suggested that the very lack of religious ordinances in the colonies and the struggle to obtain them were such that it made 'those who are religious more decidedly so. ${ }^{232}$ The fact remains, however, that colonial congregations only rarely got the outstanding clergy they apparently deserved.

There is an interesting political tangent to this issue which ties in neatly with some of the misgivings about All Hallows' priests. In the late 1860s it became apparent that in certain Australian colonies, where Presbyterian congregations were of mixed, or of majority Scottish national origin, ministers from Ireland were sometimes rejected for the very fact of their Irishness. As James Caldwell explained 'There is [...] a considerable number of Scotch people in Victoria who take the standard of all things Irish from Irish harvesters and Fenians. Such act on the principle that nothing good can come out of Ireland. ${ }^{233}$ John Wilson in Queensland wrote similarly that 'The plain sad truth is, that a minister coming from Ireland is just as likely to be a hindrance as a help. This is not the result of national jealousy, but of recent events. ${ }^{234}$ The feeling did apparently dissipate: J. M. Abernethy observed from Victoria in 1872 that 'the old reproach is now pretty well rolled away [...] no Presbyterian minister is thought the worse of for hailing from the North of Ireland'. ${ }^{235}$ However, as with the Catholic mission, it was yet another factor which may have impacted negatively on efforts to meet the spiritual needs of emigrants.

In the end, then, the efforts of each of the three churches to respond to reports of mass apostasy, however exaggerated they may sometimes have been, and to reasonable pleas for spiritual aid on the part of emigrants themselves were incomplete. This was inevitably so, given the scale of the problem. To suggest that there were often 
outstanding individuals initiating and carrying out these efforts, or that more could have been achieved with greater financial or moral support seems in some respects redundant; these truisms tend to apply to any similarly Herculean task. Yet, at the same time, it seems fair to surmise that, for all the rhetoric, aside from the driven likes of John Hand or William McClure there was a notable failure to accept serious responsibility for emigrants' religious welfare on the part of the churches that they were leaving behind. That applied both to the levels of financial support and to the standard of clerical personnel they deigned to send. In fact, as we have seen, any urgency that was attached to emigrant missions was often of precisely the wrong kind, bordering on undue, and ultimately, perhaps, self-defeating haste.

\section{Notes}

1 The title's biblical quotation (Matthew, 9:36) is taken from the King James translation, and differs slightly from the Catholic (Douay) version: 'distressed and lying like sheep that have no shepherd'. Both Protestant and Catholic clerics nonetheless made use of their preferred form when speaking specifically of spiritually-deprived emigrants. Thomas Rawlings, Emigration: An Address to the Clergy of England, Ireland, Scotland and Wales on the Condition of the Working Classes, with a few Suggestions as to their Future Welfare (Liverpool, 1846), p. 7; All Hallows Second Annual Report (1849), 22; M.G.A. (1848), 701; Anon, 'Colonial scheme of the Church of Scotland' in McComb's Presbyterian Almanack and Christian Remembrancer (1843), 85.

2 W.T., 12 Aug. 1854, 19 Aug. 1854; Tyler Anbinder, Nativism and Slavery: The Northern Know Nothings and the Politics of the 1850's (Oxford, 1992), p. 12.

3 Brian P. Clarke, Piety and Nationalism: Lay Voluntary Associations and the Creation of an Irish-Catholic Community in Toronto 1850-1895 (London, 1993), p. 35.

4 Griffin, The People with No Name, p. 91.

5 Miller et al., Irish Immigrants in the Land of Canaan, p. 436; Miller, Emigrants and Exiles, pp. 158-9.

6 Miller et al., Irish Immigrants in the Land of Canaan, p. 381. One later example is Thomas Clark of Ballybay, Co. Monaghan, who led 300 families from his congregation to the new world in 1764. I. R. McBride, Scripture Politics: Ulster Presbyterians and Irish Radicalism in the Late Eighteenth Century (Oxford, 1998), p. 115.

7 Griffin, The People with No Name, p. 158; An Orthodox Presbyterian, 'Thoughts on missions' in Orthodox Presbyterian, i:5 (Feb. 1830), 161-9. 
8 Jay P. Dolan, In Search of an American Catholicism: A History of Religion and Culture in Tension (Oxford, 2002), pp. 14-15.

9 'Report of the committee appointed by the Catholic Association, 1824' in Edmund Curtis and R. B. McDowell (eds), Irish Historical Documents, 1172-1922 (Cork, 1968), pp. 243-7.

10 Fergus O'Ferrall, “'The only lever..."? The Catholic priest in Irish politics, 1823-29' in Studies: An Irish Quarterly Review, lxx:280 (Winter 1981), 310; F.., 16 Feb. 1824; Michael Keyes, Funding the Nation. Money and Nationalist Politics in Nineteenth-Century Ireland (Dublin, 2011), p. 15.

11 Thompson, Into all Lands, p. 15; Thomas McDonald, 'The Church overseas' in Michael Hurley (ed.), Irish Anglicanism, 1869-1969: Essays on the Role of Anglicanism in Irish Life presented to the Church of Ireland on the Occasion of the Centenary of its Disestablishment by a Group of Methodist, Presbyterian, Quaker and Roman Catholic Scholars (Dublin, 1970), p. 93.

12 Audrey Lockhart, Some Aspects of Emigration from Ireland to the North American Colonies between 1660 and 1775 (New York, 1976), p. 32.

13 Daniel O'Connor and others, Three Centuries of Mission: the United Society for the Propagation of the Gospel 1701-2000 (London, 2000), pp. 28-9, as cited in W. J. Marshall, 'Irish clergy abroad' in Toby Barnard and W. G. Neely (eds), The Clergy of the Church of Ireland 1000-2000: Messengers, Watchmen and Stewards (Dublin, 2006), p. 263.

14 Donald Harman Akenson, The Church of Ireland: Ecclesiastical Reform and Revolution, 1800-1885 (London, 1971), pp. 120-1. It ought to be noted that American independence did not help matters for the S.P.G., nor did the wider challenge posed by the foundation of its evangelical rival, the Church Missionary Society, in 1814.

15 Anon., 'Missions of the United States' in Annals of the Propagation of the Faith, i:5 (Sept. 1838), 289-92.

16 F.J., 28 Feb. 1833, 20 May 1833.

17 John England to O'Connell, 4 Oct. 1823 in O'Connell, The Correspondence of Daniel O'Connell, ii, p. 512.

18 Guilday, Life of John England, ii, p. 362.

19 Ibid., i, p. 527; See also Ignatius Murphy, The Diocese of Killaloe 1850-1914 (Dublin, 1995), pp. 357-8.

20 William Bernard Ullathorne, vicar-general of New South Wales visited Ireland in search of priests in 1837. William Bernard Ullathorne, From Cabin-Boy to Archbishop: The Autobiography of Archbishop Ullathorne (London, 1941), pp. 99-100. His bishop, John Bede Polding of Sydney, led seven Maynooth graduates back to Australia in 1838. Patrick J. Corish, Maynooth College, 1795-1995 (Dublin, 1995), p. 96. Michael O'Connor, Bishop of Pittsburgh, visited Maynooth to acquire priests in 1843. I.C.R.A., Cullen Supplements, CUL/OCO/31, letter from O'Connor to Cullen, 1 Sept. 1843. 
21 Robert Boyd, 'The American Church' in Orthodox Presbyterian, v:52 (Jan. 1834), 146. The phrasing here refers to Psalm 137, 'By the rivers of Babylon..., which speaks of the difficulties of expressing one's faith in exile.

22 A. H. Wright, 'Emigration to North America' in McComb's Presbyterian Almanack (1846), 87; 'Episcopos', 'Episcopacy in America' in Christian Freeman, iii:29 (Mar. 1835), 171.

23 B.N.L., 9 July 1839; Lindsay Proudfoot, 'Place and Presbyterian discourse in colonial Australia' in Lindsay J. Proudfoot and Michael M. Roche (eds) (Dis)Placing Empire: Renegotiating British Colonial Geographies (Aldershot, 2005), pp. 72-3.

24 The bulk of the correspondence consulted for this section comprises the c.3,500 letters, mainly from Ulster emigrants to North America, on the original Centre for Migration Studies' Irish Emigration Database (I.E.D.), now digitised at www.dippam.ac.uk. Only a fraction of these letters mention religion or church-going in any depth. Some of the originals of these letters are held in the Centre for Migration Studies and some remain in private hands, in which cases the document number from the I.E.D. database has been used as the reference. Those letters located in P.R.O.N.I. have been footnoted according to their P.R.O.N.I. references.

25 I.E.D., Fitzgerald letters, 9601014, letter from Patrick Fitzgerald to Michael Cahill, 22 Nov. 1846.

26 Ibid., 9511085, letter from Eliza Fitzgerald to Michael Cahill, 4 Dec. 1845.

27 Ibid., 9601014, letter from Patrick Fitzgerald to Michael Cahill, 22 Nov. 1846.

28 P.R.O.N.I., Park and Quin papers, D/1819/8, letter from Arthur Quin to siblings, 18 Sept. 1876.

29 A.H.C., Overseas Missionary Correspondence, LRO/1: microfilm, N.L.I., p. 2849-51, letter from Andrew Byrne to John Hand, 19 Oct. 1845; Ibid., LRO/2: microfilm, N.L.I., p. 2849-51, letter from Byrne to Hand, 3 Apr. 1846.

30 F. X. Gartland of Savannah, for example, noted that he had only nine priests in his diocese which incorporated the whole of the state of Georgia and the greater part of Florida. A.H.C., Overseas Missionary Correspondence, SAV/1: microfilm, N.L.I., p. 2782, letter from Gartland to A.H.C., 16 Mar. 1851.

31 P.R.O.N.I., Clogher Diocesan Records, DIO(RC)1/11B/2, Diary of Rev. Dr James Donnelly, written during a fundraising trip in America, 1852-53.

32 On Australia, see Fitzpatrick, Oceans of Consolation, passim; Fitzpatrick, 'Beloved country', p. 335.

33 P.R.O.N.I., Crawford emigrant papers, T/2338/1, letter from Gamble Crawford to brother, 26 Mar. 1860.

34 I.E.D., Smyth letters, 0401004, letter from James Smyth to Bella M. Smyth 19 Oct. 1901. 
35 Ibid., 0410201, letter from Mary Smyth to L. C. Smyth, 30 Sept. 1902.

36 P.R.O.N.I., Greer, Hamilton and Gailey papers, D1835/27/2/2, letter from Mary Adams to William Stavely, 17 Feb. 1818.

37 P.R.O.N.I., William John Campbell Allen papers, D1558/1/1/11, letter from Mary Ann Blair to Jane Allen, 25 Sept. 1847.

38 P.R.O.N.I., Clay family emigrant correspondence, T1480/2, letter from John Henry to Mrs John Henry, 15 Nov. 1867.

39 P.R.O.N.I., R. H. Elliott papers, T3032/1/1, letter from Henry Coulter to William Moreland, 14 June 1820.

40 P.R.O.N.I., Aiken McClelland papers, T2046/5, letter from Andrew Greenlees to his brother, 10 Mar. 1854.

41 P.R.O.N.I., Armour genealogical papers, D1792/E, Alex McLeod to William Stavely, 6 Dec. 1816.

42 Ibid., D1792E, letter from McLeod to Stavely, 24 Feb. 1818.

43 Doyle, Hints, pp. 77-8.

44 T[homas] Radcliff (ed.), Authentic Letters from Upper Canada; With an Account of Canadian Field Sports by T. W. McGrath esq. (Dublin, 1833), p. 142., pp. 187-8., p. 202.

45 P.R.O.N.I., Kirkpatrick papers, D1424/11, letter from Thomas Kirkpatrick to Rev. G. Kirkpatrick, 3 Mar. 1825.

46 Buckley, Diary, pp. 245-6.

47 A.H.C., Overseas Missionary Correspondence, OTT/22: microfilm, N.L.I., p. 2849-51, letter from Fr Stenson, Ottawa to Fr William Fortune, 1873.

48 Ibid., JNFD/25: microfilm, N.L.I., p. 2849-51, letter from T. Power to Fortune, 30 July 1873.

49 Ibid., DET/1: microfilm, N.L.I., p. 2782, letter from Patrick Tierney to A.H.C., Mar. 1875.

50 I.E.D., Neill papers, 0611002, letter from Henry Neill to Samuel Neill, 16 Oct. 1839.

51 P.R.O.N.I., Hall papers, D2041/Bundle 13, letter from Maggie Black to Susan Hall, 25 June 1890.

52 'Peregrinus', The falling off of Irish Catholics in the United States', 436. The choice of pseudonym is instructive: ancient Irish missionaries termed themselves 'peregrinatio religiosa' or 'peregrinatio pro Christo', that is, religious exile or exile for Christ, signifying a deliberately chosen expatriation in the service of Jesus. Daniel Murphy, A History of Irish Emigrant and Missionary Education (Dublin, 2000), p. 54.

53 Buckley, Diary, p. 219.

54 'Peregrinus', 'The falling off of Irish Catholics in the United States', 436.

55 John McDevitt, Father Hand: Founder of All Hallows College for the Foreign Missions, The Story of a Great Servant of God (Dublin, 1885), pp. 9-10.

56 James Morgan, Recollections of my Life and Times: an Autobiography with 
Selections from his Journal edited by his Son (Belfast, 1874), p. 56; B.N.L., 12 June, 1894.

57 R. J. O’Neill, Ireland: Her Monks at Home and Abroad, A Lecture delivered to St Nicholas's Young Men's Society, Liverpool (Liverpool, 18[83?]); Thomas Nicholas Burke, Lectures on Faith and Fatherland (Glasgow, [1874]); R. W. Buckley, D.D., Saint Patrick, Apostle of Ireland and Missionary A.D. 441 to A.D. 493: The Substance of a Sermon preached in St Paul's Church, Dublin, on Sunday, March 17th, 1878 in aid of the Society for the Propagation of the Gospel in Foreign Parts (Dublin, 1879); William Thomas Latimer, A History of the Irish Presbyterians (Belfast, 1902), pp. 1-19.

58 Hogan, Irish Missionary Movement, pp. 25-51; Andrew Holmes, 'The shaping of Irish Presbyterian attitudes to mission, 1790-1840' in Journal of Ecclesiastical History, lvii:4 (Oct. 2006), 720.

59 Porter, Religion Versus Empire?, p. 160.

60 Ibid.; B.N.L., 19 Oct. 1867.

61 F.J., 15 Nov. 1843.

62 B.N.L., 17 Mar. 1854.

63 Anon., 'Our Home Mission - its nature and its claims' in Presbyterian Magazine, i (Nov. 1859), 265.

64 Samuel Hinds, The Speech of the Rev. Dr Hinds (now Lord Bishop of Norwich) at a Meeting of the Dublin University Branch of the Society for the Propagation of the Gospel in Foreign Parts, 13th December, 1846 (Dublin, 1850), p. 3.

65 Patrick Comerford, 'Success or failure?: Church of Ireland overseas missions', based on a lecture given at N.U.I. Maynooth, 3 March, 2008 http://revpatrickcomerford.blogspot.com/2008/03/success-or-failurechurch-of-ireland.html (accessed 22 Aug. 2012). Among such works are, for the Church of Ireland, Harry Vere White, Children of St Columba: A Sketch of the History, at Home and Abroad, of the Irish Auxiliary of the Society for the Propagation of the Gospel (Dublin, 1914); F. E. Bland, How the Church Missionary Society came to Ireland (Dublin, 1935); H. M. Harriss, Outward and Onward: Ireland and S.P.G., 1714-1964 (Dublin, 1964); Jack Hodgins, Sister Island: A History of the Church Missionary Society in Ireland 1814-1994 (Belfast, 1994); for the Presbyterian Church, Godfrey Brown, 'The Colonial Mission' in Jack Thompson (ed.), Into all the World: A History of 150 years of the Overseas Work of the Presbyterian Church in Ireland (Belfast, 1990), pp. 163-73; and for the Catholic Church, Kevin Condon, The Missionary College of All Hallows, 1842-1891 (Dublin, 1986).

66 Patrick O'Farrell, Vanished Kingdoms: Irish in Australia and New Zealand, A Personal Excursion (Sydney, 1990), p. 117.

67 Guilday, Life of John England, i, pp. 521-2.

68 I.C.R.A., Cullen Supplements, CUL/AME/22, letter from Francis Kenrick to Cullen, 20 Mar, 1834. 
69 Guilday, Life of John England, i, p. 536.

70 Corish, Maynooth College, p. 96; I.C.R.A., Cullen papers, CUL/1840/575, letter from Miles Gaffney to Cullen, 2 Feb. 1840.

71 Ullathorne, Cabin-boy to Archbishop, pp. 99-100. This is a more faithful version of the original manuscript source than that produced by the 'pious editress' A. T. Drane in 1892 and quoted by Larkin. Emmet Larkin, 'The beginning of the Irish effort to provide for the Roman Catholic Foreign Missions before the Famine' in Tom Dunne and Laurence M. Geary (eds), History and the Public Sphere: Essays in Honour of John A. Murphy (Cork, 2005), pp. 83-99.

72 Condon, All Hallows, p. 47.

73 Christy O’Dwyer, “'The beleaguered fortress”, St Patrick's College, Thurles, 1837-1988' in William Corbett and William Nolan (eds), Thurles: The Cathedral Town: Essays in Honour of Archbishop Thomas Morris (Dublin, 1989), p. 239; Thurles did not, however, begin producing missionary priests in numbers until the 1870s, Ibid., p. 243.

74 C.D.A., Slattery papers, 1842/26: microfilm, N.L.I., p. 6001, letter from Crotty to Slattery, 13 Nov. 1842; Ibid., 1842/27: microfilm, N.L.I., p. 6001, letter from Murphy to Slattery, 1842.

75 John Curry, All Hallows College, Dublin and its Founder (Dublin, 1900); MacDevitt, Father Hand.

76 Condon, All Hallows, pp. 11-14.

77 MacDevitt, Father Hand, pp. 101-28; Condon, All Hallows, p. 70.

78 Battersby's Registry for the Catholic World (1846), 572-3.

79 I.C.R.A., Cullen papers, CUL/1841/678, letter from Kirby to Cullen, 20 Sept. 1841.

80 Ibid., CUL/1841/700, letter from Thomas Cullen to Cullen, 24 Dec. 1841.

81 I.C.R.A., Kirby papers, KIR/1842/106, letter from Cullen to Kirby, 27 July 1842; I.C.R.A., Cullen papers, CUL/1845/1080, letter from Michael O'Sullivan to Cullen, 30 Aug. 1845.

82 Ibid.; Larkin notes that Foley became preoccupied with some apparent cases of stigmata among the young women in the adjoining refuge, to the damage of his reputation, and the college went into terminal decline. Larkin, 'The beginning of Roman Catholic Foreign Missions', pp. 83-99.

83 William Purcell, 'Father Hand (1807-1846)' in I.E.R., 5th series, lx (Dec. 1942), 415; I.C.R.A., Kirby papers, KIR/1842/106, letter from Cullen to Kirby, 27 July 1842.

84 I.C.R.A., Cullen papers, CUL/1842/720, letter from Murray to Cullen, 19 Mar. 1842.

85 Ibid., CUL/1842/733, letter from Murray to Cullen, 11 June 1842.

86 Purcell, 'Father Hand', p. 343.

87 C.D.A., Slattery papers, 1842/26: microfilm, N.L.I., p. 6001, letter from Crotty to Slattery, 13 Nov. 1842. 
88 Condon, All Hallows, pp. 76-8.

89 Anon., 'First foreign missionary from the Ulster Presbyterians' in Orthodox Presbyterian, i:3 (Dec. 1829), 98.

90 Orthodox Presbyterian, 'Thoughts on missions', Ibid., i:5 (Feb. 1830), 161-9; An Orthodox Presbyterian, 'Presbyterian missions', Ibid., ii:13 (Oct. 1830), 21.

91 Thomas Leslie is accepted to have been the first Synod of Ulster minister to serve overseas as a foreign missionary, going to Jamaica in 1835 with the Scottish Missionary Society. Bill Addley, 'Irish Presbyterian attitudes to mission before 1840' in Thompson, Into all the World, p. 21.

92 Don Chambers, 'The Kirk and the Colonies in the early 19th century' in Historical Studies [Australia], xvi:64 (1975), 381-401.

93 Anon., 'Scottish Missionary Society' in Orthodox Presbyterian, ii:22 (July 1831), 357-9.

94 Chambers notes several examples of this kind of reasoning among moderates in the Church of Scotland. Chambers, 'The Kirk and the Colonies', 399. Chapter four below explores similar thinking in the Irish church.

95 B.N.L., 31 Aug. 1838.

96 B.N.L., 18 Mar. 1842.

97 M.G.A. (1846), 488.

98 M.G.A. (1847), 592.

99 B.N.L., 15 Aug. 1848.

100 B.N.L., 11 Sept. 1840.

101 B.N.L., 29 Sept. 1848. Mant also chaired S.P.G. meetings in Ballymena and Coleraine on successive days, his 'last labours' before illness overtook him. Richard Mant, Memoirs of the Right Reverend Richard Mant, Lord Bishop of Down and Connor, and of Dromore (Dublin, 1857), p. 462.

102 Robert Knox, A Charge Delivered in the Primary Visitation of the Dioceses of Down and Connor, and Dromore, in September, 1850 (Dublin, 1850), p. 19.

103 Joseph Hardwick, An Anglican British World: The Church of England and the Settler Empire, c. 1790-1860 (Manchester University Press, 2014), ch. 5.

104 John Bull, 28 Oct. 1839.

105 Samuel Hinds, Speech of Dr Hinds...13th December, 1846; Samuel Hinds, Speech delivered at a Meeting of the Society for the Propagation of the Gospel held in Dublin in the Autumn of 1847 (Dublin, 1849); Derby Mercury, 17 Nov. 1847; Anon., Report of the Dublin and Kildare Diocesan Auxiliary to the Society for the Propagation of the Gospel in Foreign Parts for the years 1849 and 1850 (Dublin, 1851).

106 Hodgins, Sister Island, pp. 30-47.

107 B.N.L., 22 Feb. 1854, 19 May 1854. 
108 Anon., Financial Report of the Irish Auxiliary to the Colonial and Continental Church Society for supplying Clergymen, Catechists, and Teachers to the Colonies of Great Britain, and to British Sojourners on the Continent for the year ending $31^{\text {st }}$ December, 1870 (Dublin, 1871), p. 7.

109 On the continental background to Irish Catholic missionary endeavours, see Hogan, Irish Missionary Movement, pp. 55-90.

110 B.N.L., 29 Sept. 1848.

111 B.N.L., 22 Feb. 1854.

112 Hinds, Speech delivered at a Meeting of the S.P.G...1847, p. 6; see also Rowan Strong, Anglicanism and the British Empire, c. 1700-1850 (Oxford, 2007), p. 285.

113 M.H. (1853), 2085; See also Orthodox Presbyterian, vii:73 (1836), 210.

114 M.H. (1862), 67.

115 M.H. (1858), 50-1.

116 Fifth Annual Report of All Hallows (1852-3), pp. 4-5. It should also be noted that the Freeman's Journal regularly printed reports of S.P.G. meetings - perhaps a case of keeping an eye on 'the other side'.

117 Sixth Annual Report of All Hallows (1854), 15.

118 Fourth Annual Report of All Hallows (1851), 34-5.

119 Up until the 1830s, the S.P.G. received a direct grant from Westminster. Porter, Religion Versus Empire?, p. 158. In Canada up to 1840 the Anglican Church was endowed with tracts of land known as 'clergy reserves'; after that date, under pressure from the Church of Scotland, the net of those who benefited from these reserves was widened, but they were discontinued in 1854, not long after they had actually begun turning a profit for the churches. Robert Choquette, Canada's Religions: An Historical Introduction (Ottawa, 2004), pp. 220-2. In some Australian colonies, meanwhile, the colonial authorities began giving stipends to ministers of religion - regardless of their denomination - in the late 1830s, but owing to budgetary constraints these were capped in 1842. Ian Breward, A History of the Churches in Australasia (Oxford, 2001), pp. 72-5. This meant that the stipends were often not sufficient to allow the minister an adequate living. Proudfoot, 'Place and Presbyterian discourse in colonial Australia, pp. 70-1.

120 M.H. (1872), 624; M.H. (1887), 178.

121 Holmes, 'The shaping of Irish Presbyterian attitudes to mission', 728.

122 M.H. (1891), 132.

123 M.H. (1864), 332.

124 M.H. (1864), 423.

125 Wilson, a Limerick-based minister who served twice as moderator, succeeded McClure on his sudden death in 1874; Cargin of Derry succeeded Wilson in 1890, but illness meant he lasted only until 1895, when Hamill assumed the convenorship. 
126 M.H. (1852), 1027.

127 B.N.L., 18 Apr. 1889, 17 Apr. 1890.

128 B.N.L., 12 June 1894.

129 M.H. (1868), 251.

130 M.H. (1872), 624.

131 M.H. (1869), 321; M.H. (1871), 251; M.H. (1858), 15.

132 B.N.L., 15 Aug. 1848.

133 B.N.L., 10 June 1873; M.H. (1865), 647-8. 'White unto the harvest' is a biblical phrase (John, 4:35) used to refer to the ease with which souls might be 'harvested' in missionary work.

134 W. P. Addley, 'A study of the birth and development of the overseas missions of the Presbyterian church in Ireland up to 1910' (PhD thesis, QUB, 1994), p. 3.

135 M.H. (1884), 257-8.

136 Holmes, 'The shaping of Irish Presbyterian attitudes to mission', 711-37.

137 P. M. Pollock. 'Mission work in Canada' in Presbyterian Churchman (July, 1883), 155.

138 Hely Hutchinson Smith, Reasons Why Evangelicals should not Support the Society for the Propagation of the Gospel in Foreign Parts (London, 1883); Hinds, Speech of Hinds...13th December, 1846, p. 5; B.N.L., 12 July 1854; Richard Whately, Thoughts on Christian Moral-Instruction: The Necessity, and the Mode of imparting it. A Charge, delivered to the Clergy of the Dioceses of Dublin, Glendalagh, and Kildare, at the Visitation in June and July, 1854 (Dublin, 1854), pp. 41-2. Whately, as he intimated in the above charge, rejected such allegations from a strong position, his edited book Cautions for the Times having been a key anti-ritualist text. Richard Whately (ed.), Cautions for the Times (London, 1853).

139 Akenson suggests that 'Ireland was untouched by the Oxford Movement'. Akenson, The Church of Ireland, p. 207. Peter Nockles has, however, qualified this somewhat, showing that an influential, if decreasing, highchurch element continued to exist in Ireland even as evangelicals were in the ascendant. Peter Nockles, 'Church or Protestant sect?: The Church of Ireland, high churchmanship, and the Oxford movement, 1822-1869' in The Historical Journal, xli:2 (June 1998), 457-93. See also Nigel Yates, Anglican Ritualism in Victorian Britain 1830-1910 (Oxford, 1999), pp. $137-43$.

140 B.N.L., 19 Oct. 1859.

141 Anon., Dublin and Kildare S.P.G., p. 3; Anon., Financial Report of the Irish Auxiliary to the Colonial and Continental Church Society for supplying Clergymen, Catechists, and Teachers to the Colonies of Great Britain, and to British Sojourners on the Continent for the year ending 31st December, 1872 (Dublin, 1873), p. 13.

142 Whately, Thoughts on Christian Moral-Instruction, p. 41. 
143 Irish Church Directory (1874), 253; A note on numbers: according to Alan Acheson, 106 Irish clergy were sent overseas by the S.P.G. between 1824 and 1870, including 67 to Canada and 19 to Australia; Acheson, History of the Church of Ireland, p. 185.

144 By the end of the century, some 1,500 priests had graduated from All Hallows to destinations across the world. Condon, All Hallows, p. 144.

145 These included a series of advertisements headlined 'Priests for the emigrants' which appeared in the Freeman's Journal in 1853. Condon, All Hallows, p. 165.

146 W.T., 8 July, 1854.

147 Condon, All Hallows, p. 242.

148 In 1855 Kelly got permission to collect only in Boston and Baltimore. A.H.C., Overseas Missionary Correspondence, BAL/2/135: microfilm, N.L.I., p. 2782, letter from Kelly to Woodlock, 26 Sept. 1855.

149 D.D.A., Cullen papers, 45/3/File VI/1, letter from Woodlock to Cullen, 18 Jan. 1855.

150 Condon, All Hallows, p. 269.

151 Ibid., pp. 162-3. See note 118 above.

152 A.H.C., Overseas Missionary Correspondence, LOU/1: microfilm, N.L.I., p. 2782, letter from M. J. Spalding, Louisville to Woodlock, 25 July 1854 .

153 Larkin, 'The beginning of Roman Catholic Foreign Missions', p. 98.

154 A.H.C., Overseas Missionary Correspondence, NOR/1: microfilm, N.L.I., p. 2849-51, letter from Anthony Blanc to Hand, 31 Mar. 1843; Ibid., PHIL/1: microfilm, N.L.I., p. 2849-51, letter from Francis Kenrick to Hand, 18 Mar. 1844; Ibid., SLO/1: microfilm, N.L.I., p. 2849-51, letter from Peter Kenrick to Hand, 29 Mar. 1843; Ibid., NAS/1: microfilm, N.L.I., p. 2849-51, letter from Richard Miles to Hand, 20 Mar. 1843.

155 A.H.C., Overseas Missionary Correspondence, MIL/1: microfilm, N.L.I., p. 2782, letter from P. E. Moriarty to Hand, July 1845; Ibid., VIN/8: microfilm, N.L.I., p. 2782, letter from Celestine de la Hailandiere to Hand, 26 Oct. 1845; Ibid., DUB/2: microfilm, N.L.I., p. 2782, letter from Mathias Loras to Hand, 10 June 1846; Ibid., RCH/3: microfilm, N.L.I., p. 2782, letter from Richard Whelan to Hand, 23 Oct. 1845.

156 A.H.C., Overseas Missionary Correspondence, DUB/22: microfilm, N.L.I., p. 2782, letter from Clement Smyth to Woodlock, 9 Feb. 1863; Ibid., HAR/53: microfilm, N.L.I., p. 2782, letter from Francis McFarland to Woodlock, 16 June 1864.

157 'Address of the central committee of the Association for the Propagation of the Faith' in Battersby's Registry for the Catholic World (1853), 159.

158 Condon, All Hallows, pp. 165-6.

159 A.H.C., Overseas Missionary Correspondence, HART/12: microfilm, N.L.I., p. 2782, letter from John Brady to Moriarty, 10 Mar. 1848. 
160 Condon, All Hallows, p. 269.

161 Ibid., p. 165.

162 The Tablet, 11 July 1846.

163 C.D.A., Slattery papers, 1842/26: microfilm, N.L.I., p. 6001, letter from Crotty to Slattery, 13 Nov. 1842.

164 A.H.C., Overseas Missionary Correspondence, GAL/3: microfilm, N.L.I., p. 2849-51, letter from Jean Marie Odin to Woodlock, 14 May 1860.

$165 \mathrm{Ibid}$., RCH/ 3: microfilm, N.L.I., p. 2782, letter from Whelan to Hand, 23 Oct. 1845.

166 Roger Wynne, 'New South Wales' in Capuchin Annual, 26 (1959), 299-300.

167 Anthony Cleary, 'All Hallows in Victoria' in Ibid., 294.

168 Annals of All Hallows (1863), 79.

169 Kevin Condon, 'United States of America' in Capuchin Annual, 26 (1959), 315.

170 William L. Smith, Irish Priests in the United States: A Vanishing Sub-Culture (Oxford, 2004), p. 60; Second Annual Report of All Hallows (1850), p. 5; John O'Brien [Patrick Joseph Hartigan], The Men of '38 and Other Pioneer Priests, ed. T. J. Linane and F. A. Mecham (London, 1975), p. 77; Smith, Irish Priests in the United States, pp. 60-1.

171 A.H.C., Overseas Missionary Correspondence, KST/2: microfilm, N.L.I., p. 2849-51, letter from Patrick Phelan to Fr O'Brien, 1 Feb. 1848; Ibid., TOR/1: microfilm, N.L.I., p. 2849-51, letter from Michael Power to Woodlock, 17 June 1847.

172 As well as several thousand Irish immigrants, five Catholic priests and two Anglican clergymen died from typhus at Grosse Île; a further ten contracted the disease but recovered. Coleman, Passage to America, pp. $150-1$.

173 Mrs Jerome Mercier, Father Pat: A Hero of the Far West, [no pagination] (Gloucester, 1909) available at Project Canterbury, http://anglicanhistory.org/canada/fatherpat.html. (accessed 10 Apr. 2009).

174 Mercier, Father Pat.

175 Marshall, 'Irish clergy abroad', p. 271.

176 A. E. David, Handbooks of English Church Expansion: Australia (London, 1908), p. 59 available at Project Canterbury, http://anglicanhistory.org/ aus/aedavid1908/04.html (accessed 10 Apr. 2009).

177 'Setting out on foot in 1855, he made a tour of 3,500 miles' H. E. King, Australia (London, 1935), p. 39 cited in Marshall, Irish Clergy Abroad, p. 271; 'In six months he had travelled on horseback 2000 miles.' Edward Symonds, The Story of the Australian Church (London, 1898), p. 74 available at Project Canterbury, http://anglicanhistory.org/aus/ symonds1898/ (accessed 10 Apr. 2009). 
178 Anon., Financial Report of the Irish Auxiliary to the Colonial and Continental Church Society ... year ending 31st December, 1872 (Dublin, 1873), p. 7.

179 M.H. (1871), 498.

180 Ibid., 484.

181 M.H. (1873), 84.

182 M.H. (1871), 251.

183 Banner of Ulster, 29 July 1862.

184 Edwards, 'The Irish priest in North America', p. 332.

185 A.H.C., Overseas Missionary Correspondence, BO/23: microfilm, N.L.I., p. 2849-51, letter from James Healy to Woodlock, 12 July 1860; Ibid., RCH/21: microfilm, N.L.I., p. 2782, letter from Whelan to Woodlock, 23 Mar. 1857.

186 Donna Merwick, Boston Priests, 1848-1910 A Study of Social and Intellectual Change (Cambridge, Mass., 1973), p. 10; Graham Greene, The Power and the Glory (London, 1940); See also Clarke, Piety and Nationalism, pp. 36-7. The phenomenon of 'the drunken priest' in Irish folk memory has also been discussed in Lawrence J. Taylor, Occasions of Faith: An Anthropology of Irish Catholics (Dublin, 1995), pp. 145-66.

187 Richard Howley, 'Reminiscences of All Hallows' College' in I.E.R., 3rd series, xiii (Dec. 1892), 1125.

188 Condon, All Hallows, p. 276.

189 David McRoberts, 'The restoration of the Scottish hierarchy in 1878' in David McRoberts (ed.), Modern Scottish Catholicism 1878-1978 (Glasgow, 1978), p. 11.

190 Ruth-Ann Harris, The Nearest Place that wasn't Ireland: Early Nineteenth Century Irish Labor Migration (Ames, Iowa, 1994), p. 167.

191 Moriarty was introduced to Gavan Duffy in the offices of The Nation in 1845. Charles Gavan Duffy, My Life in Two Hemispheres (2 vols, London, 1898), i, p. 217; Charles Gavan Duffy, Young Ireland: A Fragment of History (London, 1880), p. 27.

192 I.C.R.A., Kirby papers, KIR/1849/623, letter from Moriarty to Kirby, 20 Apr. 1849.

193 The description comes from Oliver P. Rafferty, The Church, the State and the Fenian Threat 1861-75 (Basingstoke, 1999), p. 127. Moriarty had said that 'eternity [was] not long enough, nor hell hot enough' for the Fenians.

194 Condon, All Hallows, p. 138; O’Farrell, Vanished Kingdoms, p. 98. I.C.R.A., Kirby papers, KIR/1872/74, letter from Moran to Kirby, 21 Mar. 1872.

195 John Curry, 'All Hallow's College' in I.E.R., 3rd series, xiii (Oct. 1892), 874-85.

196 Curry, All Hallow's College, p. 17.

197 Murphy, History of Irish Emigrant and Missionary Education, p. 373.

198 See Condon, All Hallows, pp. 167-90. 
199 Fr Timoney, 'New Zealand' in Capuchin Annual, 26 (1960), 309.

200 Vincent J. McNally, The Lord's Distant Vineyard: A History of the Oblates and the Catholic Community in British Columbia (Edmonton, 2000), p. 192.

201 C.D.A., Leahy papers, 1867/26: microfilm, N.L.I., p. 6001, letter from McCloskey to Leahy, 1867.

202 Condon, All Hallows, p. 209, p. 251.

203 D.D.A., Cullen papers, CUL/43/3/3, letter from Woodlock to Cullen, 6 Mar. 1855.

204 Condon, All Hallows, p. 138.

205 Oliver P. Rafferty, 'The Catholic Church, Ireland and the British Empire 1800-1921' in Historical Research, lxxxiv:224 (May 2011), 288-309.

206 A.H.C., Overseas Missionary Correspondence, DUB/20: microfilm, N.L.I., p. 2782, letter from Smyth to Woodlock, 22 Oct. 1860.

207 Ibid., NEW/16: microfilm, N.L.I., p. 2782, letter from James Bayley to Woodlock, 29 Feb. 1860; Ibid., NEW/19: microfilm, N.L.I., p. 2782, letter from Bayley to Woodlock, 23 Oct. 1860.

208 Ibid., HAL/17: microfilm, N.L.I., p. 2849-51, letter from William Walsh to Woodlock, 13 Feb. 1848; Ibid., PIT/3: microfilm, N.L.I., p. 2782, letter from John Andre to Moriarty, 4 Aug. 1853.

209 Ibid., SAV/6: microfilm, N.L.I., p. 2782, letter from Gartland to All Hallows, 15 Mar. 1854.

$210 \mathrm{Ibid}$., VIN/4: microfilm, N.L.I., p. 2782, letter from Hailandiere to Hand, 5 Feb. 1844; Ibid., DUB/3: microfilm, N.L.I., p. 2782, letter from Loras to Moriarty, 5 Nov. 1847.

211 Moriarty to Woodlock, 8 Mar. 1859, cited in Condon, All Hallows, p. 89.

212 Curry, All Hallows College, p. 22.

213 David Moriarty, Allocutions to the Clergy and Pastorals, ed. A. Griffin and J. Coffey (Dublin, 1884), pp. 182-3.

214 Curry, All Hallows College, p. 22.

215 O’Farrell, Vanished Kingdoms, p. 98.

216 Corish, Maynooth College, pp. 39-40.

217 Patrick Murray, 'Missionary priests of All Hallows College, Dublin, from the Archdiocese of Armagh, 1842-75' in Seanchas Ardmhaca: Journal of the Armagh Diocesan Historical Society, i:2 (1955), 96.

218 Condon, All Hallows, p. 149.

219 Jeremiah Cummings, 'Our future clergy: an inquiry into vocations to the priesthood in the United States' in Brownson's Quarterly Review, i:4 (Oct. 1860), 506. This article provoked controversy in the US and Ireland. See Thomas T. McAvoy, 'Orestes A. Brownson and John Hughes in 1860' in The Review of Politics, xxiv:1 (Jan. 1962), 19-47; Henry L. Walsh, Hallowed Were the Gold Dust Trails: The Story of the Pioneer Priests of Northern California (Santa Clara, 1946), p. 39. 
220 W. T. Latimer, A History of First Ballynanty Presbyterian Church (Belfast, 1915), p. 8.

221 M.H. (1853), 2085.

222 M.H. (1862), 67; M.H. (1868), 202.

223 M.H. (1868), 201.

224 M.H. (1875), 521.

225 B.N.L., 7 June 1877.

226 B.N.L., 11 July 1861; M.H. (1861), 822.

227 M.H. (1858), 51.

228 B.N.L., 12 July 1866.

229 M.H. (1872), 624.

230 Edward Marcus Dill, The Mystery Solved: Or Ireland's Miseries: The Grand Cause and Cure (Edinburgh, 1852), p. 19.

231 MacKenzie, The Emigrants' Guide, p. 54.

232 M.H. (1884), 268.

233 M.H. (1869), 266.

234 M.H. (1869), 439.

235 M.H. (1872), 706. 
Part II 



\section{4}

\section{The battlefield against popery: emigration and sectarian rivalry}

'If each priest were to take a wife about four thousand children would be born within the year, forty thousand would be added to the birth rate in ten years. Ireland can be saved by her priesthood!'

George Moore, The Untilled Field (1903)

Thus concluded the fictional Fr MacTurnan, so petrified that 'Ireland would become a Protestant country if the Catholic emigration did not cease, that he dispatched to Rome an heretical suggestion of rescinding clerical celibacy. ${ }^{1}$ This may have been a slice of farce typical of the modern Irish short story (of which Moore is often deemed the first exponent), but the demographic fears underlying the plot were not without a grounding in reality. ${ }^{2}$ While the previous chapters have focused on the various forms of influence which clergy exercised, and failed to exercise, over emigration, a significant strand of clerical commentary on the subject concerned the opposite: the effect the exodus might have on the churches, and more specifically, on the balance of power between them. This was a necessarily combative discourse, based on zero-sum assumptions that the Protestant interest' was strengthened by every Catholic departure and vice versa. It was manifested most virulently in the middle decades of the century and was inextricably bound up with the contemporaneous efforts of evangelical Protestants to convert Catholics in the so-called 'Second Reformation'. Partly by mining the wealth of controversial written material produced by Protestant missionaries and their Catholic counterparts during this period, this chapter will attempt to ascertain how clergy believed their churches might be impacted by the substantial loss of population which emigration represented.

Between 1849 and 1852, as the immediacy of the Famine crisis dissipated and priests returned to being primarily religious pastors 
rather than relief organisers, many of them began evaluating how the dust of five years of death and emigration had settled on their parishes. Even before the official census revealed a deficit of two million people - some $20 \%$ of the total pre-Famine population - despairing clerics from all over the country roughly enumerated their own local losses. ${ }^{3}$ Fr Heslin, a Leitrim priest informed the Freeman's Journal that since 1844 his congregation had diminished by 'fully one-fourth. ${ }^{4}$ Michael Coghlan, parish priest in Collinstown, Co. Westmeath, had seen 'the whole of what may be truly called the "flower of the flock" depart. One Fr O'Dogherty told an Omagh Tenant Right meeting that his parish, one of the largest in Ulster, had 'diminished by several thousands. ${ }^{6}$ Another such meeting at Westport was addressed by a Fr Ward who asserted that 'considerably more than one-half were gone' from his parish 'by famine, by emigration and by extermination from the face of the country'? The most alarming estimate, however, came from an anonymous priest near Clonmel, who caused widespread shock with his revelation that 'two-thirds of my own congregation have departed to the workhouse or gone to America.8 That much of this came prior to the year of most departures - 1852 - suggests many of these parishes had yet to reach their ultimate low. ${ }^{9}$

The practical consequences were soon evident in parish life. Reports of chapels closed because of congregations 'annihilated' in parts of Co. Clare were the thin end of a very long wedge. ${ }^{10} \mathrm{~A}$ traveller in more prosperous Co. Wicklow found that 'the chapel of Killaveny, a large building, was not one half so full on Sundays as formerly. ${ }^{11}$ Similarly, one letter-writer informed emigrant relatives that 'one ile of our Chapel would hold our congregation on Sunday at present,, ${ }^{12}$ while Archdeacon Fitzgerald of Limerick relayed the sombre fact that the priest of a neighbouring parish now employed a man 'to scrape the floor of his chapel, which, without such care, would soon come to be covered with grass, as his congregation consists on Sundays of a few files ranged along the chapel walls, leaving the centre of the aisles wholly unoccupied. Six years ago the same chapel was full to suffocation. ${ }^{13}$ With such reports, it is unsurprising that poets felt inspired, one contributor to the Nation composing a lament for 'The deserted chapel. ${ }^{14}$ For the anonymous Clonmel priest, meanwhile, the reduced circumstances of his Sunday congregation seemed as melancholy as their reduced numbers: 
I was, God help me, very proud of my flock seven or eight years ago. I rejoiced - I felt perhaps an unbecoming pride - when they crowded around my chapel in their holiday finery. [...] My chapel always overflowed - there is hardly a third of it occupied at present - and the showy gowns and ribbons, and the flashy kerchiefs have almost disappeared. There is, instead, squalor and rags, tottering old age and no children. ${ }^{15}$

On a personal level, for a clergy wholly dependent on the offerings of their parishioners, these scenes were surely frightening. The Famine and continued emigration, as the Nation later observed, 'robbed the priest of his dues. ${ }^{16}$ 'The farmers who have any means are emigrating, and did emigrate, announced the parish priest of Ballycastle, Co. Mayo, 'I have only the paupers, and as many as have any money they are very cautious to retain the same. ${ }^{17}$ The usual sacramental offerings could not be fallen back on. As emigration continued to swallow the younger generations, marriages were few and far between, or even 'nil' as one priest told the Cork Examiner. ${ }^{18}$ Consequently Baptisms were, as Fr Heslin and others noted, 'not one to four of former years', i.e. less than a quarter of the normal baptismal dues. ${ }^{19}$ At least two chapels actually closed because reduced congregations proved unable to support their priests, and several other clergymen expressed a desperate fear that they might eventually be forced to follow or even 'accompany the remnant of their flocks abroad' although, as has been seen, few followed through with the idea. ${ }^{20}$ For a brief time, the feeling that emigration meant Ireland was, in one Irish Conservative MP's triumphant words, 'ceasing to be a Catholic nation' seemed all too plausible a reality to many priests. ${ }^{21}$

This prospect provoked strident reactions from Catholic and Protestant alike. A significant rump of Catholic priests, particularly younger curates, were politicised by it. The advent of the Tenant League in 1850, which saw land reform as the remedy for Irish ills, was in great measure hastened by clerical involvement, urged on by the argument persuasively put forward by 'A Munster priest' to his colleagues in the pages of the Nation: 'The rapidly decreasing incomes of your respective parishes prove to you how deeply you are concerned, if your people go on thus to fill up the workhouses, and fly in emigrant ships from the wreck which your country is fast becoming. 'Indifference,' he warned, 'is a terrible crime at such a crisis. ${ }^{22}$ Equally, the Catholic Defence Association, an organisation founded a year later with more narrowly religious grievances, and which, despite attempts to broker 
co-operation (thwarted by Archbishop Cullen), took much of the clerical wind out of the Tenant League's sails, attracted its share of priestly support by invoking the demographic price of inaction: 'If the people continue to pour out of the country with the same frantic haste as at present,' an early supportive editorial observed, 'there will soon be no priests for the missions, no congregations to preach to, no students for the University, no people to hold Diocesan jurisdiction over. ${ }^{23}$ While the Ecclesiastical Titles Bill, rather dramatically painted as the penal laws redux, could not, as Cullen found, rouse many parish clergy to anger, the rapid depletion of their own congregations clearly could. ${ }^{24}$

In spite of parallel Presbyterian and Anglican congregational losses and, in some cases, consequent financial straits, and despite the Nation's and the Tenant League's efforts to bind Presbyterian and Catholic clergy together on the issue of emigration, some of the more trenchant Protestant commentators saw in all of this activity the selfish efforts of priests set merely on retaining their own income and status. ${ }^{25}$ 'The Roman Catholic clergy sustain a severe loss and drawback in their pecuniary resources, in consequence of the tide of emigration continuing to roll unabated,' wrote the Protestant Limerick Chronicle approvingly in $1852 .{ }^{26}$ The Dublin Evening Mail, likening clerical attempts to stop emigration with efforts to 'restrain the ocean with a pitchfork', suggested that the priests would soon have to emigrate themselves, thus ridding Ireland of 'a most intolerable incubus. ${ }^{27}$ In her letters from Ireland in the same year, Harriet Martineau suggested that, as a result, the 'priesthood is obviously destined to decline', notwithstanding that 'it may become more noisy and quarrelsome as it declines. ${ }^{28}$ This became a recurring theme. Catholic priests' opposition to emigration during its later peaks in the early 1860s and the early 1880 s were characterised as a defence of their personal income and influence. ${ }^{29}$ The Nun of Kenmare, Mary Francis Cusack, attacked this accusation head-on. 'The Irish priest's income is of very little moment to him,' she asserted, 'and the only influence he desires is to keep his people from the eternal ruin which is too often the sure end of wholesale emigration.' ${ }^{30}$

Even as late as 1880 , however, such outright denial was disingenuous. As emigration proceeded from areas that were already the poorest, particularly in the west and south, it is clear that many parishes and dioceses did struggle financially, and that the fact preyed on clerical minds. The parish priest of Cratloe, Co. Clare told Kirby 
in 1863 that having lost more than half of his congregation to emigration, he was hardly able to support himself, let alone his new curate. ${ }^{31}$ The Archbishop of Cashel, Patrick Leahy, elaborated on the problem as he saw it:

The revenues of the priests and more especially of the bishops in the south of Ireland are diminished to a large amount. [...] The revenues of Cashel in the Irish famine year were all at once knocked down full one half while the expenses of living were in a manner doubled. The revenue of Cashel on my accession were therefore very much reduced and within the last two or three years they are still further reduced by another hundred or two \& so that it is no easy matter to manage, while demands of every kind are multiplying expenses every day. ${ }^{32}$

Edward McGennis, the Bishop of Kilmore, later confirmed that, as renewed emigration had caused 'a great decrease of marriages and deaths', the outlook was 'not encouraging.. ${ }^{33}$ That these later complaints were expressed privately, however, demonstrates an acquired reluctance to provide hostages to fortune in a climate of sectarian animosity.

Nevertheless, while reductions in offerings can only have intensified many Catholic priests' dismay over emigration, it was not their chief reason to regret their departed parishioners. In fact this dismay was simply an alarming symptom of the primary malaise. Arnold Schrier has suggested, following Cusack and others, that fears over emigrants' faith were of much greater concern to priests than loss of dues. ${ }^{34}$ Measured by print acreage alone, that might well be borne out. Worries over emigrant welfare of one kind or another dominated most public clerical commentary on the subject. However, as we have seen, the action following on from this powerful rhetoric left something to be desired. It was arguably, therefore, a more general, usually privately expressed concern over the fate of the church in Ireland that lay behind some of the most fervent anti-emigration sentiment. If Leahy's lament that 'in a short time the Protestants will outnumber us' and if so 'we are lost, as a Nation, as a Catholic nation' represented the pessimistic end of a spectrum, the more bullish reaction of James Redmond to another priest's suggestion that the Protestant population was gaining ground on the Catholic - 'At the worst of times I maintained we more than held our own' - was at the other. ${ }^{35}$ Both show, however, that at times the possibility of Ireland losing its majority Catholic status, of 'the faithful [being] supplanted by the proselytised', was widely entertained. ${ }^{36}$ It followed that mass emigration, as the main ongoing agent 
of such an outcome, had therefore to be resisted, condemned and lamented by Catholic clerical spokesmen.

It was equally disingenuous, therefore, for Protestant commentators to claim that only a mercenary interest in retaining a steady stream of financial dues prompted priests' dismay over emigration, since there had been an active effort on behalf of evangelical Protestant clergy to bring about the very scenario that Catholic clergy most feared. As the name suggests, the second or new 'Reformation' was regarded by its protagonists as an overdue attempt to complete what had failed in the seventeenth century, by reconciling Ireland to 'Protestant truth. ${ }^{37}$ In the end, it was singularly unsuccessful, but, as we will see, emigration played a significant role in its messy resolution, and featured prominently in the various narratives constructed for and against it during its lifetime. In a sense, therefore, the controversy can be seen as a distillation of wider clerical attitudes: many Protestant and Catholic conceptions of migration and how it might affect their churches are present here, albeit often in their most extreme form. This section will explore them.

The new religious movement had its immediate roots in the rise of Irish evangelicalism in the late eighteenth century, and began in earnest in the 1820s when a section of Church of Ireland clergy, encouraged by the spectre of Catholic Emancipation, embraced what had hitherto been the marginal preserve of Methodists and Nonconformists. ${ }^{38}$ The initial peak came in 1822-27, when Bishops William Magee and James Doyle were prominent advocates on either side of an often bitter theological pamphlet debate..$^{39}$ Over the ensuing two decades, the controversy this debate created fed into the proselytising activities of several evangelical missionary societies. These included the Irish Society for Promoting the Education of the Native Irish through the Medium of their Own Language (henceforth the Irish Society), the Islands and Coast Society, the Presbyterian Church's Mission to Roman Catholics (or Home Mission), and perhaps most famously, the Society for Irish Church Missions. All of these organisations laboured primarily in Connacht and along the western seaboard, although at various points there were significant pockets of activity in counties Cavan, Offaly, Tipperary and Dublin.

The primary motivation of the missionaries, as Donal Kerr has identified, was 'to rescue the people from the darkness of popery and priestcraft and to bring them to the pure light of the gospel', although this development was also expected, in turn, to render a majority 
Protestant Ireland more amenable to political integration. ${ }^{40}$ To this end the societies' activities involved the employment of 'colporteurs' who distributed bibles, and scripture readers who recited them, and, perhaps most importantly, the provision of education to Catholic children in mission schools. Where appropriate, these labours were carried on through the Irish language. Significantly, the pupils at such schools, in common with those adults who entertained bible readers, did not always formally renounce their Catholic faith. However, Protestant missionaries tended to regard them as being on the brink of conversion, and for many Catholic priests, attendance alone signified an egregious 'perversion'.

This initial missionary push appears to have had moderate success, and a number of formal conversions certainly did take place. As Desmond Bowen has outlined, these could cause great tension in a locality, representing as they did, 'a shift in the uneasy balance of power between the two peoples. ${ }^{41}$ Consequently, the idea of gathering converts in protective 'colonies' began to take hold in the mid-1830s, with the most infamous and enduring examples springing up at Dugort on Achill Island, at the instigation of the Rev. Edward Nangle, and on the Dingle peninsula, where a number were established with the enthusiastic aid of Lord Ventry. While Irene Whelan has traced this development to the influence of the previously discussed Protestant Colonisation Society, the evidence is too faint to make the link conclusively. Indeed, it seems equally likely that the very nature of the missions - led by incoming pastors, isolated from larger concentrations of the Protestant population, eventually requiring a church and school, and subject to the disdain of the surrounding community (very often including the resident Protestant clergy) - inevitably precipitated the formation of enclosed settlements. ${ }^{42}$ What is not in any doubt is that such settlements were also intended to act as bases for evangelisation of the wider district, efforts which merely increased tensions. ${ }^{43}$

The high water mark of this activity and of these tensions came during the Great Famine. The potato blight was initially perceived, even by Archbishop MacHale, as a heavenly judgement on the religious failings of the Irish people ${ }^{44}$ but Protestant evangelicals in both Britain and Ireland, and in both the Anglican and the Presbyterian churches, took it as a sign that their work to spread the gospel among Catholics should be expanded and intensified. It was not the first time that a crisis had been so greeted. The entry of Nangle 
and others into the missionary fray came on the heels of a harvest failure in 1831 which appeared to present an opening for interventions offering scriptural instruction in tandem with temporal relief. ${ }^{45}$ In that light, the intense and prolonged suffering of the Great Famine seemed the ultimate such opportunity. Alexander Dallas, the English founder of the Irish Church Missions, believed in retrospect that the Famine 'brought on a new crisis in the minds of the Irish people, loosening them from priestly power and preparing them to receive the gospel. ${ }^{46}$ The secretary of the Presbyterian Home Mission, John Edgar, similarly told his church's General Assembly that ,'The famine has been overruled for good, in weakening the power of the Romish priests and giving access to the Romish people. ${ }^{47}$

Critics of the renewed missionary push saw something rather different to the simple crisis of faith in the Catholic clergy implied here. 'Access to the Romish people' was, the Catholic press alleged, gained through bribery and deceit. William Flannelly, Catholic curate in Clifden, Co. Galway, complained to the Lord Lieutenant of 'ranting fanatical firebrands going from village to village and from house to house, seducing the poor people with a paltry bribe in one hand and corrupt fragments of the Protestant bible in the other'. Evangelicals, the accompanying editorial asserted, were 'seeking to force conscience by pots of porridge. ${ }^{48}$ Bowen has argued that such 'souperism' was never as widespread as Catholic allegations would suggest, and has largely exonerated the mainstream of the established church from the worst charges ${ }^{49}$ Indeed, Edmund Walsh, Church of Ireland rector in Abbeyfeale, Co. Limerick, was among those who at the time warned Catholics against 'the moral miasma of the proselytising soup-kitchen. ${ }^{50}$

However, there can be little doubt that, as Bowen acknowledges, the provision of material aid was a tactic consciously used by the more zealous missionary societies to gather audiences and to encourage attendance at mission schools. ${ }^{51}$ Some exercised that tactic more bluntly than others. Mrs Houston, an Englishwoman who herself set up a mission school in Co. Mayo, criticised Nangle for 'taking advantage of the bitter distress which reigned supreme in the heart of Achill's barren mountains.5. ${ }^{52}$ Other visitors were struck by Nangle's lack of 'a human view of the human wants and feelings of these poor islanders'. His philanthropy, they concluded, was entirely 'political', not to say as mean as circumstances allowed. ${ }^{53}$ Dallas was also open about his use of material attractions, though he considered that 'a providential decision' had brought about such relief. 'Souls are there, still on earth, within 
the reach of gospel salvation, who would otherwise have passed out of the body in darkness, he asserted. ${ }^{54}$ Yet, on occasion, the missionary societies were also responsible for freely given and vital famine relief. Despite local animosities, Dingle missionaries were reported to have stepped in to plug the outdoor relief gap for the general population in 1847. ${ }^{55}$ Meanwhile John Edgar's famous Cry from Connaught appears to have fomented a truly charitable endeavour, religiously indiscriminate in its distribution of considerable aid to those in distress, to the extent that a good portion of the money donated went through the hands of the Catholic Bishop of Killala. ${ }^{56}$

The notion of missionaries 'buying conversions' is therefore a difficult one to prove or disprove. Edgar certainly believed that his efforts might encourage those relieved to feel gratitude and give their benefactors a hearing, and that in responding to the 'famine of bread' in a Christian manner, the 'spiritual famine' from which he felt Connacht also suffered might be better addressed. ${ }^{57}$ With no obligation to convert involved, this barely merits the term 'souperism', with all its negative connotations. Moreover, as Thomas O'Neill noted, any direct, negotiated exchange of religious affiliation for material gain was a private bargain, unlikely to be spoken of openly and honestly by either party.$^{58}$ Nonetheless, the apparent mass conversions of 1848-49 can only be understood in the context of continued deprivation. ${ }^{59}$ There was clearly an understanding on the part of some Catholics that their public religious profession (as distinct from their 'soul') was a commodity that might earn them a living or a meal when all else failed.

That essential fact meant two things for Catholic clergy who would stop the mooted reformation in its tracks. Firstly, it gave strong grounds for alleging that the hundreds and thousands of converts which mission societies boasted of in their extensive publicity were not sincere in their conversions. This formed the basis of a nationwide counter-campaign of propaganda which was largely carried on through the Catholic press, and of which Fr Flannelly's above interjection is a typical example. Secondly, it necessitated more specifically local action against those Catholics who, in a phrase resonant to this day, 'took the soup'. Lest all Catholics in desperate straits think that 'bartering [...] the true faith of their fathers' would have no adverse consequences, converts, and especially those who acted as scripture readers, were, as a matter of course, to be ostracised, and 'treated with the silence which [their] conduct deserved'. ${ }^{60}$ This tended also to extend to an economic embargo on convert colonies, with a number of 
missions complaining that, at the behest of their priests, local people would not trade with them, or give employment to their adherents. ${ }^{61}$

The Catholic backlash was also characterised by a violence, which, though mostly verbal, produced heated conflict. Most of the missionary societies' reports allege the hounding of converts by the 'Romish priests' and their flocks. The case of one, Timothy Horan, recalled by a minister connected to the missions, was said to be typical. The 'usual consequences' followed his conversion:

He was denounced in the Roman Catholic chapel; and his friends, no less attached to him than before, dared not hold intercourse with him. The only employment he could obtain was from a Protestant gentleman [...] When this work was over, seeing no prospect of being able to live at home, he saved a few shillings and managed to make his way to London. ${ }^{62}$

Even at this stage, where they did not already exist, externally funded colonies, with model farms or industrial schools attached, could be seen as the solution to this fate. As a Cavan agent of the Irish Society noted in 1846, 'my mind is strongly impressed with the necessity and advantage that might arise from colonising our persecuted Converts [...] Some of our most useful men are driven to foreign lands, to seek the protection that should obtain in their own.63

The true extent of this persecution and its effect cannot be absolutely established. Stories like Horan's were undoubtedly exploited by the societies, and perhaps exaggerated, in order to attract the English and Scottish funding that was their lifeblood. ${ }^{64}$ That being said, there is little doubt that the majority of converts were subject to this kind of treatment to some degree. Most, whether in colonies or not, became detached from the surrounding Catholic community, were derided by their former friends as 'cait breac', and were often verbally attacked from the altar by former priests. ${ }^{65}$ Archbishop MacHale himself is reported to have indulged in the latter, Nangle quoting him on a visit to Achill in 1851 urging listeners to show no kindness to those who differ from you in their religious opinion; withhold from them the commonest courtesies of life; they are accursed of God and his church; and they should be abhorred by you; put them in Coventry; shame them into a profession of Popery; and if that won't do shame them into a hypocritical conformity'.66 Nangle was at best paraphrasing whatever MacHale had said here, but the prevalence of this kind of pulpit denunciation was demonstrated by the fact that the Catholic 
hierarchy forbade the practice in 1854 , and confirmed by the need to reinforce the ban with the threat of clerical suspension in $1858 .{ }^{67}$

Allegations that priests' attacks on converts and missionaries went beyond the pulpit and turned physical were also common. In his memoir, the Protestant missionary Thomas Armstrong wrote of an especially vicious sermon by a priest on Achill regarding the 'jumpers' of the Nangle colony, in which he urged those listening to 'Scald them, scold them, hurt them, shout after them, persecute them to death, and pull down their houses over their heads. ${ }^{68}$ Armstrong also recalled a visit by the Belfast missionary Edward Dill to Connacht in 1847, when Fr Timlin, the local parish priest, seemingly barged into the crowd outside the church during Dill's sermon looking for 'the cock of the north' so that he might horsewhip him. To much Protestant disgust, a majority Catholic jury later acquitted Timlin of the resultant charges of assault and causing a riot and a pamphlet of the trial proceedings was even produced in Belfast for those who wished to share in the outrage. ${ }^{69}$ Meanwhile, Armstrong had his own brush with clerical violence in his church in Ballina, Co. Mayo, where his attacker subsequently appealed 'in support of priestly flagellation to the authority and example of the Saviour in the Temple! ${ }^{70}$

Naturally, a lot of these claims cannot be substantiated and must be taken with a pinch of salt. However, two things can be noted in their support. The first is the rather imaginative nature of some of the attacks. Allegations of a Catholic crowd throwing a dead cat and a fish into the open carriage of passing Protestant missionaries in Doon, Co. Clare, for example, seem too ridiculous to have been invented. As do reports of a missionary in Cushendall ('the Sebastopol of Romanism in Ireland') which detailed the abuse he and his fellow missionaries were routinely subjected to when passing by groups of Catholic farm labourers: "here come the Bible-readers, soupers, black devils, jumpers, robbers, hairy dogs." The last title is comparatively new; it is because of my bear-skin-coat [...] a volley of rotten vegetables invariably follows. ${ }^{71}$ The second is that there were often reports in the Catholic press making equally serious, if also rather blackly humorous allegations of violence on the part of Protestant missionaries, including one memorable incident where a drunken scripture reader attacked a Franciscan friar with an umbrella. ${ }^{72}$ Clearly, 'bible war' was sometimes all too apt a metaphor.

Little wonder, one might conclude, that many converts who found themselves at the centre of such an uneasy atmosphere of violence and 
intimidation sought, like Timothy Horan, to escape it by emigrating. Indeed, converts having to depart 'for the truth's sake' or in order 'to have the liberty in a foreign land of worshipping God according to the dictates of their conscience' became a common claim in mission reports, and a regular feature of pro-Reformation literature. ${ }^{73}$ This, of course, tied in neatly with a familiar trope of both Presbyterian and Anglican clerical rhetoric that, historically, their brethren had been obliged to leave Ireland for specifically religious reasons. What applied in eighteenth-century Ulster, or in 1830s Longford or Tipperary, it was claimed, was now also true of pockets of Connacht or Kerry. Historians of these earlier migrations have noted the difficulty of untangling the religious and economic motivations for emigrating, notwithstanding that religious persecution or sectarian violence were routinely considered by Protestant clergy as the root cause, as we have seen. ${ }^{74}$ Despite the obvious difficulties many converts faced, their emigration during the Famine and its aftermath was no less ambiguous a process.

Indeed, it is significant that emigration seemed to emerge as an issue for convert communities only after the onset of the Famine. Thomas Moriarty, himself a convert and head of the Irish Society's mission at Ventry, noted in 1845 that of the forty families in his area who had converted, only two had emigrated..$^{75} \mathrm{He}$ noted elsewhere in the same year that despite the persecution of converts in Dingle and Ventry, 'we are still over 150 families, amounting to more than 800 souls, thank God, besides all who have departed this life in the faith, and some who have emigrated' [emphasis added] ${ }^{76}$ By 1855 , however, Moriarty was acknowledging that emigration was a constant and serious threat to his mission. ${ }^{77}$ This certainly seems to suggest that, contrary to much missionary rhetoric, a desire for freedom from religious persecution did not alone account for convert emigration. Why could persecution apparently be borne in 1845 but not in 1855? In fact, as with most departures during the period, there was a strong economic survival element in the resolve of converts to leave. For all the allegations of 'souperism' that abounded during the Famine, Protestant missionaries were ultimately incapable of financially supporting and retaining in Ireland even those converts they had acquired before the Famine. They may have relied, in many instances, on external funding and imported provisions, but the mission colonies cannot have been immune from the intense and prolonged shortages of the Famine and its aftermath, nor, by extension, from the crisis emigration they induced. ${ }^{78}$ 
Nonetheless, several Protestant missionaries went so far as to accuse Catholic priests of actively encouraging their converts to leave. The Irish Society's 1846 report noted the plight of a former Repeal warden in Londonderry, who had started reading scripture in the hope of refuting the missionaries, only to find himself convinced of its virtue. $\mathrm{He}$ and his family became Protestants, but 'the priest made great offers to him, if he would only leave the country; he was the great champion of Romanism here. There was not a Protestant in the country could meet him. The priest does not ask him to return [to Catholicism], only to leave the place. ${ }^{79}$ When the man refused the priest's alleged bribery and stayed put, he was reputedly the victim of a campaign of vandalism. Less high profile converts were said to have been offered similar bribes. In 1847, the Dingle mission reported on the early re-conversion attempts of a Catholic Vincentian mission from Dublin: 'They have promised such as would go back, weekly subsistence, and to give them passages freely to America in the Spring. ${ }^{80}$ Other Kerry agents of the Irish Society reported the same, one noting that several converts known to him had been offered $£ 5$ passage money if they would only return to Mass once before emigrating; another that the counter-missionaries 'sent agents to the most ignorant converts, and promised them two stone of meal, every week til May, and then to send them to America free [...] But most of the converts refused.' ${ }^{81}$

That most refused is at least partly borne out. The leader of the Vincentian counter-mission, Fr McNamara, noted that for all the excitement which the visit to Kerry had generated, few had actually reneged on their conversions for fear, one historian has suggested, of the financial consequences. ${ }^{82}$ However, later events in Kerry suggest that the substance of the wider charge - that many Catholic priests were content to see the emigration of converts and would-be converts - may also have held true. In 1849, the previously mentioned Fr John O'Sullivan publicly addressed the people of Templenoe parish, who he felt were perilously vulnerable to the proselytising of Rev. Denis Mahoney, telling them to 'emigrate, emigrate, emigrate'. In the United States, he told them, 'you will not be liable to the intrusion of a blackguard, who [...] seats himself coolly on your hearth, and tells you to your teeth that your Holy Religion is blasphemous and abominable. ${ }^{83}$ This was all framed in terms of the addressees' material wellbeing, but in private O'Sullivan admitted that the tactic, though risky, was being employed primarily 'with a view to annoy Denis Mahoney. ${ }^{84}$ 
Another O'Sullivan from Kerry, the parish priest of Dingle, Fr Eugene, essayed a similar strategy with considerably less acumen in a series of letters to the Tablet in 1852. Answering Protestant allegations that he had bribed converts with free passages, he explained that some 'perverts' had asked me 'would I not send them, as I did others, to America?':

I said I would endeavour to do so, but would not make any absolute promise. This circumstance gave rise to a report that I was to send all the perverts to America. The effect which this report produced was thrilling. Numbers of them ran in haste to have their names put down to be sent to America. [...] The fact is if I gave myself any trouble about them in taking down their names, there is scarcely a single pervert in the town of Dingle that would not fling Parson Lewis to the winds if the head of the family received the means to emigrate.

He ended this letter by asking, 'what is to be done to prevent perversion - to uproot Souperism? After mature deliberation, I unhesitatingly declare that by emigration the whole can easily be effected' ${ }^{85}$ Thus, strangely, while endeavouring to deny Protestant missionaries' claims that he and others offered free passages to those who renounced their conversions, O'Sullivan seems to have convinced himself that exporting converts was indeed the very course of action to take. Publicly, at least, this does not appear to have gone down terribly well within his own church, and both the Nation and the Tuam Herald roundly criticised his suggestion. ${ }^{86}$ The former questioned whether, if O'Sullivan was enabled to send his repentant flock to America, 'the damnable system [would] be uprooted': 'Would it not remain behind to infect the new population that would necessarily settle in the district? - would not a new harvest grow up for the Devil to reap? - and would not the gold of England be lavished, as of old, to corrupt and destroy ${ }^{87}$ O'Sullivan dismissed this oddly adapted Malthusian argument in his next letter by referring by name to upwards of sixty former converts who had gone to America, and whose places in the mission colony had not been taken. ${ }^{88}$ However, while he continued for some time to advocate emigration as a kind of reverse souperism and as an effective means of undermining the Protestant missions, there was an increasing sense in these letters that O'Sullivan was speaking out of turn: that he was the only Catholic spokesperson willing to publicly state what others may have privately felt. 
There was further hypocrisy, therefore, in Catholic reactions to the developing narrative of Protestant missions as they passed their peak in the early 1850 s, that the decrease in their numbers was largely a function of emigration. Catholic anti-'souper' rhetoric, of which there was a very great deal, tended to gloss over the issue of convert emigration entirely. One must assume that this was partly because it did not fit the Catholic Church's preferred narrative. It seemed to imply, after all, either that Protestant 'bribery' of converts could not exist on the scale claimed, or that Protestant accusations of 'persecution' and consequent banishment had some merit. When emigration in connection with the missions was mentioned by Catholic commentators, it was in a much more useable form. The Weekly Telegraph, for example, reported in 1853 that 24 young men and women had left West Clare for America to escape the proselytising of the local land agent, who was affiliated to the Irish Church Missions, and that the Nangle mission had shamelessly exploited the wrecking of the California emigrant ship off Achill Island by attempting to convert the survivors against their will. ${ }^{89}$ Most tellingly, however, any attempt by evangelicals to explain the shrinking of their flocks as the result of emigration was greeted by the Catholic Church, if at all, with a rather smug derision. Such claims were, some suggested, 'A very nice, easy way of getting out!' Indeed, the Fathers of Charity order, conducting a counter-mission in 1853, preferred to see the decrease in convert numbers purely as the fruit of their own and others' like efforts, no matter that one local priest specifically told them that emigration was contributing towards the desired outcome in the Achill colony. ${ }^{90}$

The 'counter-Reformation' was itself the subject of controversy within the Catholic Church. It was on this score that Fr Robert Mullen, a Westmeath curate whom Cullen had sent to America to fundraise for the Catholic University, wrote his previously cited letter to The Tablet warning of mass apostasy among Irish Catholic emigrants. Two million Irish Catholics, he claimed, had been lost to the church in the previous three decades, not because of any fault with the overstretched American clergy, but because of Irish clerical neglect. His intervention came prefaced with specific criticism of the concentration of church resources in Connacht:

Leave the Protestant establishment to fester in its rottenness for a time; it is a sore, all the appearances whereof indicate proximate suppuration [...] Are all the energies of the new association [Catholic Defence 
Association] to be directed to prevent the proselytism of a few? Is there to be no voice raised, no hope held out, that will keep the people at home, and thus save millions from spiritual destruction?"1

If Mullen thereby hoped to concentrate clerical minds on the emigrant's spiritual plight, he succeeded, but decidedly not in the way that he had intended. As indicated in Chapter Two a minor panic was generated in the diocese of Killaloe, but his comments had their greatest and most enduring impact on Protestant evangelicals, who gleefully seized upon them as proof of the decline of Catholicism worldwide. This was an understandably attractive prospect to those working for, but evidently now failing to attain, that very outcome in Ireland. As the Presbyterian missionary Hamilton Magee later noted, 1852, an election year full of 'political and religious excitement', was a turning point for the Irish missions, as an emboldened priesthood was able 'to turn the tide back into its old channels.9 ${ }^{92}$ There was, therefore, a notable shift in Protestant missionaries' rhetoric from 1852 onwards, in great measure prompted by Mullen's report. So, while in 1847 the Dingle mission was contemplating any emigration from its ranks as a failure, and in 1850 it was only reluctantly willing to see emigration employed as a temporary relief measure, two years later, the emigration of converts was being painted by missionaries as the work of divine Providence. ${ }^{93}$ As the Islands and Coast Society asserted:

The thoughtful Christian is led to admire and adore the inscrutable wisdom of that Master-mind, which, seeing the end from the beginning, is able to order all events for the carrying out of his own grand, and well-digested plans. From every part of the coast, and "from the Isles of the Sea" has been heard the resolution to depart, bearing the Word of Life to distant shores, where its lessons of peace and love might be carried into effect unchecked, at least by opponents under the garb of piety. ${ }^{94}$

Underpinning this sentiment, compensatory though it undoubtedly was, were Protestant perceptions of the providential effect of emigration on Catholics in general. A feeling had already begun to emerge - in Britain and America as much as in Ireland - that most Irish Catholic emigrants, and most certainly their children, would fully succumb to Protestant evangelism once abroad and away from their priests. ${ }^{95}$ In letters that were reprinted in Belfast with an introduction by John Edgar in 1851, Nicholas Murray, an Irish emigrant who had 
converted to Presbyterianism in America and eventually rose to the moderatorship of the American General Assembly, indicated why: 'in Ireland you might be afraid of the priest's whip, or of his cursing you from the altar [...] But here his whip has no terror and his curses are harmless. ${ }^{96}$ In the wake of Mullen's unintended confirmation of this assertion, commentators were able to proclaim that 'the salt sea is a rapid solvent of the abject popular veneration which [the priests] command at home', and that 'once on the soil of the United States, it is well known how freely the Irish immigrant chooses his own religion according to the new lights and new influences around him. ${ }^{97}$ The Presbyterian missionary Edward Dill concurred. In a state-of-thenation thesis published in 1852 he assigned all of 'Ireland's miseries' to Catholicism, and though he warned Britain and America of the dangers of being overwhelmed by Catholic emigrants, he also felt that once away from 'horsewhipping priests' and surrounded by good Protestant example, they could '[rise] to comfort and [walk] with God. ${ }^{98}$ Edgar, meanwhile, described, on the one hand, 'our Romish population, like fiery flying serpents [...] spreading over the face of other lands', but felt, on the other, that what most of them sought in the United States was freedom from clerical oppression, thus making them prime candidates for conversion. ${ }^{99}$

Given this reaction to his letter, and the persistent invocation of it over many years to come, it is clear that Fr Mullen had been rash in publishing his views. ${ }^{100}$ His wiser colleagues realised as much immediately. A fellow Catholic University collector, on seeing The Tablet, complained in his diary of 'such imprudence and indiscretion!! Will he ever have sense?'. At home, Cullen and the university committee had Mullen's bishop upbraid him, and were soon dismayed to note that 'the abominable press' had begun giving 'pointed remarks on the most mischievous parts. ${ }^{101}$ In thus speaking out, it was clear that Mullen had provided Irish evangelicals not only with the evidence - however erroneous it was ${ }^{102}$ - to buttress their alternative explanation for the apparent post-Famine failure of their 'reformation', but also with the grounds to continue their conversion efforts notwithstanding that failure.

Certainly, having bought into all of the above, it may seem surprising that Protestant missionaries did not then deem their own work in Ireland to be superfluous. However, as an 1853 report from Connacht stated, the mission schools having lost some two thousand pupils by emigration in the last few years, 'what a blessed thing it is, 
that, before leaving, they were thoroughly instructed in the truth that makes free. ${ }^{103}$ If the emigration of converts made for loss of morale amongst missionaries, not least, as one noted, because 'those who have gone were missionaries at home to their parents and other relations, ${ }^{\prime}{ }^{104}$ they could take heart from the notion that the emigrants would act similarly in their new homes. The acclamations of sister churches seemed also to confirm these hopes. An Edinburgh correspondent told the General Assembly in respect of its Home Mission that 'you do not know all the good you are doing. I was glad to hear that some girls who were at your school but never professed Protestantism, regularly attend Protestant worship here; and there are many such cases. ${ }^{105} \mathrm{An}$ American church told the same body that 'the progress of the truth in your island affects us almost as directly as if the movement had occurred in our own country.' ${ }^{106}$ While 'Americanus' told the Irish Presbyterian:

The Irish Protestant comes here with his joyousness, versatility, frugality and social habits, on the whole, to do us good. But the Irish Papists come in swarms, on the whole, to do us evil [...] My way of solving it is to educate the people and Christianise them. This is the best and cheapest way; and you owe it to yourselves, and to us, to do so. Then Ireland will be a noble arm of Britain, and because of the migratory character of her people, a fountain of blessings to all the earth. ${ }^{107}$

The galvanising idea that 'Ireland is thus the battlefield against Popery for Britain and America and all the world' seems to have taken a firm hold in Protestant missionary circles. ${ }^{108}$ It became a given that, as the Islands and Coast Society explained, 'the religious interest of Australia, North America and Ireland have become strangely united by the unprecedented tide of emigration going forth from this land' and that Irish missionaries should therefore 'joyfully prepare the sons and daughters of Ireland for emigration, that they may bear fruit to the glory of God and of their parent land, and not cause disgrace. ${ }^{109}$

Thus, a situation where many Irish evangelicals held that a combination of conversion and emigration would equalise the Catholic and Protestant populations, or even enable the overthrow of Irish Popery altogether, had fundamentally altered. While in 1848 even the relatively moderate Presbyterian missionary Hamilton Magee was confident enough to state that 'The final evangelization of Ireland is certain,, ${ }^{110}$ by 1852 even the more ambitious Alexander Dallas, then barely started on his mission, was, according to his wife, privately 
'brought to feel that his work was to be, not the external reformation of Ireland as a nation, but the gathering of individual souls for the "multitude which no man can number", in the future kingdom of Christ." ${ }^{111}$ The undoubted success of the Catholic counter-missions, which were rejuvenating Catholic congregations all over the island by the early $1850 \mathrm{~s},{ }^{112}$ was sobering from a Protestant point of view, but Fr Mullen's report of mass apostasy among Catholic emigrants seemed to offer a lifeline. It suggested that the 'bible war', which many missionaries felt was being lost by Protestants in Ireland itself, could nevertheless be won on a different front. The emigration of converts, or of those who had gone through mission schools without ever formally converting, or even of the far greater number of Catholics who had never yet shown an interest in the Protestant religion, could therefore be seen in a positive light, as part of a greater divine plan to defeat Catholicism on a global scale. ${ }^{113}$ Therefore, from about 1852 onwards, most Irish evangelicals increasingly saw their role as being a religious filter in the emigration process, producing a 'fountain of blessings to all the earth'.

Precisely how accurate all of this was is obviously open to question. Mullen's dubious figures aside, the only evidence offered for the mass conversions of Irish Catholic emigrants is anecdotal, and, as in an 1858 book by Daniel Foley, came from interested sources. ${ }^{114}$ Moreover, later warnings in the vein of Mullen's - usually from Irish-American clergy who might well have been unaware of Irish evangelical gloating on the subject - tended, even in private, to emphasise that Catholic apostates were generally lost to all religion, and did not in fact convert to other churches in great numbers. ${ }^{115}$ It is probable, as has been seen, that Catholics in remote areas reconciled themselves to Protestant denominations in the absence of a priest, but it seems unlikely that their numbers justified Irish evangelical jubilation. As one Catholic priest responding to an old Irish Society report countered, 'The miracle is that no one has seen those large armies of converts [in America].'. ${ }^{116}$ Nevertheless, by citing the continued exodus, both from their own convert communities and the wider Catholic population, Irish evangelical clergy had managed to grasp a face-saving narrative of global victory from the jaws of what was increasingly looking like a resounding home defeat.

This particular wishful thinking did not entirely obscure the previous fiction, however. Dallas's Irish Church Missions, the most enduringly successful of all the Protestant mission societies, 
continued to suggest for some years that emigration and conversion, working in tandem, were ridding Ireland of 'Popery', although it was largely a device to attract vital finance from English evangelicals who still longed for that outcome. ${ }^{117}$ The 1861 census, the first to record religious affiliation since 1834, finally disabused these backers of any such notions, as despite considerable prior wrangling over alleged flaws and deceits in the data collection, it showed no great levelling of the Protestant and Catholic populations, merely a slight proportional realignment. ${ }^{118}$ It was clear that, even if the Catholic Church had borne the greatest losses, all the churches had been considerably affected by famine and emigration.

However, while the hope of a new Protestant reformation had been common to clergy in the Church of Ireland and the Presbyterian Church, they received this final deathblow to any serious entertainment of the concept very differently. 1861 found Presbyterian clergy in Ulster in a relatively secure position, which had, in great measure, been created by the very emigration the census recorded. Firstly, there was an argument - as we have seen, not entirely rejected by Presbyterian commentators - that emigration over the previous decade had rendered better the economic lot of those left behind. ${ }^{119}$ What is more, it was generally agreed that the purportedly transformative religious revival that had swept through Presbyterian congregations in 1859 had been in some measure precipitated by similar occurrences in North America in 1857-58. ${ }^{120}$ Intelligence of the American 'awakening' had certainly been relayed to the north of Ireland via emigrant correspondence, as well as through the close ties between the two regions' churches born of decades of Irish westward migration. ${ }^{121}$ These links would only strengthen in the decades to come, thereby confirming Ulster's pivotal place in the greater evangelical Atlantic world. ${ }^{122}$ Therefore, while the census may have revealed that emigration had deprived the Presbyterian Church in Ireland of up to a fifth of its adherents over the preceding three decades, and hastened the decline of its Home Mission into practical irrelevance, it was also immediately apparent to Presbyterian clergy that the outflow had not been without its own advantages to their communion.

The 1861 census offered the Church of Ireland no such comfort. In the run-up to the census-taking, the stakes many Anglican clergy invested in procuring a favourable result had been high, encompassing not merely the fate of the mission societies and their stated objective, but, contrary to one historian's claim, the survival of the church 
establishment itself. ${ }^{123}$ Much depended, it was clear, on the census showing an unambiguous movement away from Catholic domination and toward the Church of Ireland. ${ }^{124}$ When it was shown that, despite huge Catholic losses, the Anglican proportion of the population had only marginally increased to just $11.9 \%$ there were numerous attempts to spin the results, including continued questioning of the methodology employed, an emphasis that in certain districts the Anglican population had increased, and reference to the fact that relative decline in each church - roughly a fifth of Presbyterians, a third of Catholics and an eighth of Anglicans - clearly favoured the Church of Ireland. ${ }^{125}$ However, this litany of defensive literature in the 1860s merely confirmed that the writing was on the wall for the establishment. One lecture was even printed with an appendix of Fr Mullen's Catholic apostasy figures as if to remind readers that there was a global Plan B. ${ }^{126}$ Last-ditch attempts were made by some parish clergy to enumerate their own congregations, but even the would-be compiler of this project was 'not too sanguine as to the result. ${ }^{127}$ The clamour for disestablishment could no longer be resisted, and when it inevitably came to pass, a Catholic balladeer made great play of turning Protestant rhetoric on its head:

Sure this great Emegration or extermination, From the Irish nation will shortly take place, And every white choaker souper ranter or groper, From Dingle to Derry must join in the chace...

No longer the blessed big belly'd parsons,

Will preach that papists are out of their wits,

Since they got this brain blow they must bundle and go

As their Church is not worth a two penny bit. ${ }^{128}$

Having beaten back Protestant missionary encroachment on their flocks, and seen the demise of the much-resented Anglican establishment, Catholic priests could be expected to feel smug. Certainly, these must have seemed remote possibilities to the demoralised incumbents of grass-grown chapels twenty years earlier. The great irony was that emigration, which, in tandem with famine-related deaths had more than decimated the Catholic population, had also directly contributed to these more welcome outcomes. What is more, as Emmet Larkin famously observed, the post-Famine increase in vocations begun under Cullen's watch was enhanced by the corresponding loss of population: one priest for every 2,000 parishioners in 1850 became one 
for every 1,250 in $1870 .{ }^{129}$ One can dispute the effects of this increased ratio, and, as Eugene Hynes has noted, implications of unquestioned clerical rule can easily be debunked, but the statistic was certainly a favourable one for the church, and one which was as totemic a sign of the devotional revolution as any other. ${ }^{130}$ While it would be a step too far to surmise from all of this that Catholic clergy actively conspired to seek or to encourage mass emigration, it must be pointed out that neither were they entirely incognizant of the benefits of the exodus to the church in Ireland.

In that sense, the actions of the two Fr O'Sullivans and of unnamed others in the face of the Protestant missions were indicative of a hidden truth: emigration, on occasion, solved problems. ${ }^{131}$ Sustained economic and social ostracising of 'jumpers' clearly helped to hasten the departure of some genuine converts who could not be won back to Catholicism, while many of those whose conversions had been of less certain sincerity, could in essence be bribed back with the offer a new life abroad. As an aside, one has to admire the brazen use that some individuals therefore made of the religious conflict that had sprung up around them: playing one side off the other to attain a living at home, followed by a passage to America could represent an effective survival strategy. ${ }^{132}$ From the Catholic Church's point of view, however, the excision of such devotionally unreliable, not to say economically underachieving adherents, who seemed only to offer the possibility of further embarrassment down the line, was logical. No church, and especially not one aspiring to an increasingly demanding orthodoxy, could tolerate the perpetual idle threat of the wayward or desperate parishioner that they might, as one Jesuit later put it, take up with the agents of souperism when they did not get their own way with the priest. ${ }^{133}$

This unsentimental acknowledgement that there were some people whose emigration was tolerable, if not desirable, was not confined to Protestant converts, nor to the religiously wanton. At a more subtle level, hinted at above, there were also internal class considerations at play. As historians have recognised, a key factor in the post-Famine success of Catholicism was that the less conventionally devout elements of pre-Famine society - the rural poor - had been in large part swept away by death and emigration, leaving an already more orthodox and prosperous farming class behind. ${ }^{134}$ That process was only accelerated in the ensuing decades, and Catholic clergy were well aware of what it meant for their institution. ${ }^{135}$ Implicit in many of their 
public and private laments over emigration, therefore, was that some departures were to be regretted more than others. Thus it was that Dr Miley, in publicly disagreeing with Fr Maher's planned emigration scheme, did so on the basis that it targeted better-off farming families, 'the very class who are the main stay of religion in Ireland', which, 'now more than ever the vital interests of the universal church calls loudly on us not to relinquish. ${ }^{136}$ With the farmers readying to 'make off with all they can \& emigrate from this land of woe,' as a Kinsale priest told Cullen, there was a prospect that 'next year we shall have no one in the country but inmates of work houses. ${ }^{137}$

Such an eventuality clearly would not do, and when there were signs of an increase in farmers leaving some districts during the early 1860s economic downturn, something akin to panic once again set in. That 'all the small farmers are utterly gone' was the trigger for Archbishop Leahy's above-mentioned jeremiad, while a Cork priest complained, that 'those who remain (as a rule) are either Catholics that is half-Protestant, or else poor people, many of whom there is good reason to know have not frequented the sacraments since the publications against the St Patrick's Brotherhood or the Fenians appeared. ${ }^{138}$ Leaving aside the political implication in this latter statement, the fear that the church in certain areas of the west and south was losing many of the most 'respectable', devout and therefore the most valuable of its communicants to emigration was palpable. An earlier imploration in a pastoral letter issued by Cullen makes sense in this context. Prompted, in part, by Daniel Cahill's glowing account of America in his popular series of letters to the Catholic Telegraph (which comprised the emigrant guide mentioned in Chapter Two), the primate repeated the usual warnings against emigration before going on, remarkably, to recommend it to any who 'by remaining at home, consider it probable that they shall be compelled to terminate their days in those disgraceful abodes of crime and wretchedness the poor houses. ${ }^{\prime 39}$ That, of course, had a lot to do with the maintenance of individual dignity. However, the dignity and standing of the Catholic Church in Ireland, and the farming elite on which it relied, cannot, as ever, have been far from Cullen's mind.

George Moore's priest, eager to see the 'flower of the nation' - that is, the priests, who 'live in the best houses, eat the best food, wear the best clothes' - produce 'magnificent sons and daughters' in the cause of maintaining Ireland as a predominantly Catholic country was therefore not entirely the stuff of fiction. This better class of repopulation, 
though imaginary and played for comic effect, was clearly in line with the interests of the Catholic Church. That Moore could write as much in 1903, moreover, reflects the fact that, notwithstanding the results of the 1861 census, real fears continued to be harboured by Catholic churchmen in areas where an occasional spike in emigration still threatened to remove 'the flower of the flock'. There are echoes in all of this of Protestant concerns as expressed to the Poor Inquiry some years earlier: for a number of reasons, financial and devotional, no cleric wished to lose those better-off parishioners who were 'the chief ornament of [his] church'. In neither case did that denote an active desire to see the expatriation of the less devout lower orders, but it did suggest a hierarchy of regret, in which, for each denomination, the religious 'other' came bottom and the most religiously committed and economically comfortable families of the clergyman's own church came top. In that light, if a winner was to emerge from the 'bible war', it should, in theory, have been evangelicals, who, despite failing to gather the expected numbers of converts, or indeed hold on to those they did convert, had witnessed the concurrent emigration of millions of Catholics. However, one Protestant commentator admitted in 1854 that, 'the experience of a few years has blasted the expectations of even the most sanguine.' The Famine, he explained, had not dealt the expected deadly blow to Catholicism, since the two million lost to Rome were among the poorest, and those who weathered the storm found themselves better off as a result and as attached as ever to their priests. ${ }^{140}$ This continued to be the upshot of much later emigration: as Daniel McGettigan, Archbishop of Armagh noted in 1884, despite having lost thousands of young people from the diocese over the previous decade, 'we have still a fair population and on the whole, very good and virtuous.' ${ }^{141}$

\section{Notes}

1 George Moore, The Untilled Field (London, 1903), pp. 175-97.

2 Misgivings over priestly celibacy were also not unknown, as a pamphlet from some years earlier attests. Anon., Remarks on the Celibacy of the R.C. Clergy by the Rev the P.P. of County of Ireland. Part 1 (Dublin, 1839). On Moore see Frank O’Connor (ed.), Modern Irish Short Stories (Oxford, 1957).

3 Vaughan and Fitzpatrick, Irish Historical Statistics, p. 3.

4 F.J., 15 June 1849.

5 F.J., 9 Mar. 1849. 
6 F.J., 28 Oct. 1850.

7 F.J., 31 May 1850.

8 F.J., 10 Oct. 1851; The Nation, 17 Jan. 1852.

9 Vaughan \& Fitzpatrick, Irish Historical Statistics, p. 261.

10 F.J., 13 Feb. 1849.

11 John Forbes, Memorandums Made in Ireland in the Autumn of 1852 (2 vols, London, 1853), i, 37.

12 Miller, Emigrants and Exiles, p. 300.

13 The Nation, 29 Nov. 1851.

14 The Nation, 8 Mar. 1851.

15 F.J., 10 Oct. 1851.

16 The Nation, 12 Feb. 1853.

17 The Tablet, 12 June 1847; See also Scally, End of Hidden Ireland, p. 75.

18 The Tablet, 3 Jan. 1852; The Nation, 8 Nov. 1851.

19 The Nation, 14 Feb. 1852.

20 Thomas Lacy, Home Sketches, on Both Sides of the Channel, being a Diary (London, 1852), pp. 125-6; F.J., 13 Feb. 1849; The Tablet, 3 Jan. 1852; Select committee on outrages, p. 356, H.C. 1852 (438), xiv, 375.

21 The Nation, 13 Dec. 1851.

22 The Nation, 27 Oct. 1849. On clerical involvement in the Tenant League, see O'Shea, Priests, Politics and Society, pp. 59-63.

23 The Nation, 10 May 1851.

24 Bowen, Paul Cardinal Cullen, p. 126.

25 F.J., 12 Dec. 1848; Armagh Guardian, 18 Dec. 1848; B.N.L., 19 June 1849, 23 Mar. 1851; The Nation, 21 June 1851.

26 B.N.L., 7 Jan. 1852, 15 Sept. 1851.

27 The Anglo-Celt, 19 Aug. 1852.

28 Harriet Martineau, Letters from Ireland, ed. Glenn Hooper (Dublin, 2001), p. 155; Belfast Mercury, 16 Oct. 1852.

29 B.N.L., 30 Jan. 1880.

30 Cusack, Case of Ireland, pp. 223-4.

31 I.C.R.A., Kirby papers, KIR/1863/179, letter from John Bourke to Kirby, 3 July 1863.

32 Ibid., KIR/1863/101, letter from Leahy to Kirby, 27 Mar. 1863.

33 Ibid., KIR/1889/176, letter from McGennis to Kirby, 3 May 1889.

34 Schrier, Ireland and the American Emigration, p. 64.

35 I.C.R.A., Kirby papers, KIR/1863/101, letter from Leahy to Kirby, 27 Mar. 1863; D.D.A., Cullen papers, 340/1/I/90, letter from Redmond to Cullen, 17 July 1861.

36 The Nation, 13 Dec. 1851.

37 Nigel Yates, The Religious Condition of Ireland 1770-1850 (Oxford, 2006), p. 271; William Harris, Failure of the Reformation in Ireland: Its True Causes developed in a Petition to the House of Lords, by a Protestant 
Layman (Dublin, 1837).

38 Irene Whelan, The Bible War in Ireland: The 'Second Reformation' and the Polarisation of Protestant-Catholic Relations, 1800-1840 (Dublin, 2005), pp. 86-92; Bowen, Protestant Crusade, pp. 61-2.

39 Strictly speaking, the term 'Second Reformation' refers to this specific period, although Whelan uses it in a more general sense. Whelan, Bible War in Ireland, p. xviii; see also Stewart J. Brown, The National Churches of England, Ireland, and Scotland 1801-1846 (Oxford, 2001), pp. 93-167.

40 Kerr, Nation of Beggars, p. 207; Hempton and Hill, Evangelical Protestantism, pp. 81-102.

41 Bowen, Protestant Crusade, p. 143.

42 Whelan, Bible War in Ireland, pp. 251-65.

43 Ibid., p. 263.

44 The Tablet, 20 Feb. 1846, 29 Aug. 1846. For Protestant expression of the same sentiment see Hugh McNeile, The Famine a Rod of God: Its Provoked Cause - its Merciful Design. A Sermon preached at St Jude's Church, Liverpool on Sunday, Feb. $28^{\text {th }}, 1847$ (Liverpool, 1847); James Morgan, Thoughts on the Famine, its Author, Cause and Remedy (Belfast, 1847); Peter Gray, 'National humiliation and the Great Hunger: fast and famine in 1847' in I.H.S., xxxii:126 (Nov. 2000), 203-9.

45 Whelan, Bible War in Ireland, p. 254.

46 Alexander R. C. Dallas, The Story of the Irish Church Missions continued to the year 1869 (London, 1875), p. xvii.

47 W. D. Killen, Memoir of John Edgar (Belfast, 1867), pp. 227-34; B.N.L., 6 July 1849.

48 F.., 2 Mar. 1849.

49 Bowen, Souperism, pp. 227-34.

50 The Tablet, 24 June 1847.

51 Bowen, Souperism, pp. 115-16.

52 [Matilda Charlotte] Houston, Twenty Years in the Wild West, or Life in Connaught (London, 1879), p. 47.

$53 \mathrm{Mr}$ and Mrs S. C. Hall, Ireland its Scenery Character and History (6 vols, Boston, 1911), vi, p. 153; A[senath] Nicholson, Annals of the Famine in Ireland, in 1847, 1848, and 1849 (New York, 1851), p. 161.

54 Miriam Moffitt, Soupers and Jumpers: The Protestant Missions in Connemara (Dublin, 2008), pp. 18-19; Alexander R. C. Dallas, Castlekerke (London, 1849), p. 22.

55 Bowen, Souperism, p. 82.

56 Bowen, Protestant Crusade, p. 33.

57 R. J. Rodgers, 'Vision unrealised: the Presbyterian mission to Irish Roman Catholics in the nineteenth century' in Bulletin of the Presbyterian Historical Society of Ireland, xx (Mar. 1991), 21; Killen, Memoir, pp. 230-4; M.H. (1846), 376-80; M.H. (1847), 399-400. 
58 Thomas O'Neill, 'Sidelights on souperism' in I.E.R., $5^{\text {th }}$ ser., lxxi (Jan. 1949), 55; Bowen, Souperism, p. 125.

59 Irene Whelan, 'Edward Nangle and the Achill mission, 1834-1852' in Raymond Gillespie and Gerard Moran (eds), 'A Various Country' Essays in Mayo History 1500-1900 (Westport, 1987), p. 128.

60 W.T., 12 Mar. 1853.

61 D. P. Thompson, A Brief Account of the Rise and Progress of the Change in Religious Opinion now taking place in Dingle and the West of the County of Kerry (London, 1846), p. 199.

62 Thomas Olden, 'Reading the Irish bible: history of a convert from Romanism' in Charles Bullock (ed.), What Ireland Needs: The Gospel in the Native Tongue (London, c. 1880), p. 113.

63 Anon., The Twenty-Eighth Report of the Irish Society for promoting the Education of the Native Irish through the Medium of their own Language: for the year ending 17th March, 1846 (Dublin, 1846), p. 36; Anon., The Twenty-Ninth Report of the Irish Society for promoting the Education of the Native Irish through the Medium of their own Language: for the year ending 17th March, 1847 (Dublin, 1847), p. 49; James Mecredy, The Reformation in Iar Connacht (Dublin, 1853), p. 10.

64 Moffitt, Soupers, p. 91.

65 Cait breac meaning 'speckled cat', i.e. neither one colour nor the other: neither Protestant nor Catholic. Hugh Dorian, The Outer Edge of Ulster. A Memoir of Social Life in Nineteenth-Century Donegal eds Breandán Mac Suibhne and David Dickson (Dublin, 2000), p. 204.

66 J. G. MacWalter, The Irish Reformation Movement and its Religious, Social and Political Aspects: Embodying a Compendium and Consecutive History of Ireland's Early Church, its Fall, and every Missionary Organisation which has Laboured up to the Present Time to Restore Pristine Purity with Practical Inferences (Dublin, 1852), p. 200.

67 O'Neill, 'Sidelights on souperism', p. 58.

68 Thomas Armstrong, My Life in Connaught with Sketches of Mission Work in the West (London, 1906), p. 84.

69 John Edgar, Ireland's Mission Field: A Paper read at the Sixth Annual Conference of the British Organisation, August, 1852 (London, 1852), p. 3; B.N.L., 1 Feb. 1848; Anon., Trial of Priest Timlin, for Riot and Assault at Ballymaciola, County Mayo on Sabbath October 31, 1847 (Belfast, 1848).

70 Armstrong, My Life, p. 52., p. 96.

71 Alex. R. C. Dallas, 'Irish Church Missions' in Christian Examiner, vi:149 (Dec. 1855), 178.

72 W.T., 12 Mar. 1853.

73 Anon., The Thirty-First Report of the Irish Society for promoting the Education of the Native Irish through the Medium of their own Language: for the year ending $31^{\text {st }}$ March, 1849 (Dublin, 1849), p. 35; W. A. C., Mick Tracy, 
the Irish Scripture Reader, or the Martyred Convert and the Priest (London, 1866), p. 27; 'The author of Mick Tracy' [W. A. C.], Tim Doolan, the Irish Emigrant (London, 1869), p. 11.

74 Dickson, Ulster Emigration, pp. 37-47; Griffin, The People with No Name, p. 66; Miller et al., Irish Immigrants in the Land of Canaan, p. 5; Elliott, Irish Migrants in the Canadas, pp. 36-60; Kerby A. Miller, 'The lost world of Andrew Johnston: Sectarianism, social conflict, and cultural change in southern Ireland during the pre-Famine era' in James S. Donnelly, Jr and Kerby A. Miller (eds), Irish Popular Culture, 1650-1850 (Dublin, 1998), pp. 222-41.

75 Charles Gayer, Persecution of Protestants in the year 1845, as detailed in a Full and Correct Report of the Trial at Tralee, Thursday, March $20^{\text {th }}, 1845$ for a Libel on the Rev. Charles Gayer (Dublin, 1845), p. 16.

76 Letter from Moriarty reprinted in Thompson, A Brief Account, p. 205.

77 Thomas Moriarty, Dingle and Ventry Mission (Dublin [?], 1855 [?]), p. 3.

78 Mealla Ní Ghiobúin, Dugort, Achill Island. 1831-1861. The Rise and Fall of a Missionary Community (Dublin, 2001), pp. 60-3.

79 Anon., Twenty-Eighth Report of the Irish Society, p. 32.

80 Anon., Twenty-Ninth Report of the Irish Society, p. 44.

81 Anon., Report of the Dingle and Ventry Mission Association, County Kerry, Ireland for the year ending 1st Dec., 1849 (Dublin, 1850), p. 13., p. 45; Missionaries in Cape Clear, West Cork noted similar efforts 'to bribe some of the convert families for emigration'. Anon., Yearly Statement of Missionary Progress of the Islands and Coast Society, 1852 (Dublin, 1852), p. 41.

82 Mary Purcell, The Story of the Vincentians (Dublin, 1973), p. 116; James H. Murphy, 'The role of Vincentian parish missions in the 'Irish counterreformation' of the mid nineteenth century' in I.H.S., xxiv:94 (Nov. 1984), $152-71$.

83 Tralee Chronicle, 10 Mar. 1849.

84 Lyne, Lansdowne Estate, pp. 85-6.

85 The Tablet, 13 Nov. 1852.

86 The Tablet, 18 Dec. 1852.

87 The Nation, 20 Nov. 1852.

88 The Tablet, 18 Dec. 1852.

89 W.T., 29 Oct. 1853; W.T.., 19 Nov. 1853.

90 Anon., Missions in Ireland: Especially with Reference to the Proselytising Movement: Showing the Marvellous Devotedness of the Irish to the Faith of their Fathers by one of the Missioners (Dublin, 1855), pp. 138-9. This was a direct response to claims made in William Marrable, Sketch of the Origin and Operations of the Society for Irish Church Missions (London, 1852), p. 40. On the wider significance of the parish mission, see Emmet Larkin, 'The parish mission movement, $1850-1880$ ' in Bradshaw and Keogh, Christianity in Ireland, pp. 195-204, and for further accounts 
of Catholic missionaries in Ireland, see Kevin A. Laheen, 'Jesuit parish mission memoirs 1863-76 Part 1' in Collectanea Hibernica, 39/40 (1998), 272-311; Kevin A. Laheen, 'Jesuit parish mission memoirs 1863-76 Part 2, 1870-2' in Collectanea Hibernica., 41 (1998), 153-224; Michael Baily, 'The parish mission apostolate of the Redemptorists in Ireland, 1851-1898' in Raphael Gallagher and Brendan MacConvery (eds), History and Conscience. Studies in Honour of Father Sean O'Riordan, CSsR (Dublin, 1989), pp. 274-96; Joseph Prost, A Redemptorist Missionary in Ireland, 1851-1854. Memoirs by Joseph Prost ed. Emmet Larkin and trans. Herman Freudenberger (Cork, 1998).

91 The Tablet, 10 Apr. 1852; F.., 24 Apr. 1852.

92 Hamilton Magee, Circulation of Douay Testaments in Ireland (Dublin, 1855), p. 1.

93 Anon., Report of the Dingle and Ventry Mission Association, County Kerry, Ireland, for the year ending $1^{\text {st }}$ December, 1847 (Dublin, 1848), p. 13; N.L.I., Tracts on Popery, P 1583, letter of Arthur Edward [Gayer?], visitor to Dingle mission, 10 Sept. 1850; Anon., Report of the Dingle and Ventry Mission Association, County Kerry, Ireland, for the year ending $1^{\text {st }}$ December, 1850 (Dublin, 1850), p. 14.

94 Anon., Islands and Coast Society, 1852, p. 8.

95 B.N.L., 13 Feb. 1849; M.G.A. (1851), p. 135; Manchester Guardian, 1 Nov. 1851.

96 Kirwan [Nicholas Murray], Letters to the Right Rev. John Hughes, Roman Catholic Bishop of New York, with an Introduction by John Edgar, D.D. (Belfast, 1851), pp. 72-3; see also Edgar in Banner of Ulster, 28 Feb. 1860.

97 Manchester Guardian, 24 Apr. 1854; The Times, 30 June 1853. See also B.N.L., 4 Apr. 1853; Anon., Correspondence between the Rev. D. W. Cahill, D.D. and some Protestant Ministers of the Town and Neighbourhood of Sligo, who invited him to a Public Discussion (Sligo, 1855), p. 36; Henry Seddall, Edward Nangle: Apostle of Achill; A Memoir and a History (London, 1884), p. 207.

98 Dill, The Mystery Solved, p. 302.

99 Edgar, Ireland's Mission Field, pp. 4-5.

100 References to Mullen's letter permeated all subsequent Protestant thinking on Irish emigration and 'Romanism in America'. See, for example, 'Editorial' in Catholic Layman, i:9 (Sept. 1852), 103-4; MacWalter, Irish Reformation, p. 282; Edward A. Stopford, A Reply to Sergeant Shee (Dublin, 1853), p. 77; B.N.L., 15 May 1854; Anon., 'The young convert' in Catholic Layman, iv:44 (Aug. 1855), 87-8; Daniel Foley, The People and Institutions of the United States of America: A Summer Vacation Tour (Dublin, 1858), pp. 13-14; [Thomas Croskery], 'The Irish abroad' in Edinburgh Review, cxxvii (Apr. 1868), 502-37; B.N.L., 14 Jan. 1869; Robert Stewart Menzies, 'The Irish in America' in Westminster Review, cxxix:1 (Jan. 1888), 713-32. 
101 P.R.O.N.I., Clogher Diocesan Records (Roman Catholic), Donnelly papers, DIO(RC) $1 / 11 \mathrm{~B} / 2$, Diary of Rev. Dr James Donnelly, written during fundraising trip in America, 1852-53; D.D.A., Cullen papers, 45/2/File III/1852/2, letter from William Skelly to Cullen, 25 Apr. 1852. The 'abominable press' in this instance included The Times, 12 Apr. 1852.

102 Shaughnessy, Has the Immigrant kept the Faith?, p. 242; Richard J. Purcell, 'The United States of America. The Irish emigrant, the famine and the Irish-American' in I.E.R., 5th ser., lxix (Oct. 1947), 864.

103 Anon., 'Notes of a tour in Connaught' in Irish Presbyterian, i:4 (Apr. 1853), 109.

104 Mecredy, Reformation, p. 10.

105 Anon., 'Connaught mission' in Irish Presbyterian, ii:20 (Aug. 1854), 134.

106 M.G.A. (1853), 219.

107 'Americanus,' 'Irish missions' in Irish Presbyterian, vi:37 (Jan. 1856), 21; see also Achill Missionary Herald and Western Witness, 25 Oct. 1853.

108 Anon., 'Connaught mission' in Irish Presbyterian, ii:20 (Aug. 1854), 134.

109 Anon., Islands and Coast Society, 1852, pp. 47-8.

110 M.H. (1848), 524; This counters Bowen's suggestion that the idea of converting Ireland was the sole preserve of more radical, aggressive English evangelicals. Bowen, Protestant Crusade, p. 207.

111 A. B. Dallas, Incidents in the Life and Ministry of the Rev. Alex R. C. Dallas ... by his Widow (London, 1871), p. 406.

112 A number of reports on missions and confirmations noted the considerable size of congregations notwithstanding recent population losses. F.J., 12 Sept. 1851, 19 Sept. 1851, 4 May 1855.

113 This was reinforced by the number of trained convert missionaries who, for one reason or another, emigrated from the 1850s onward. See Miriam Moffitt, The Society for Irish Church Missions to the Roman Catholics, 1849-1950 (Manchester, 2010), p. 111.

114 Foley, professor of Irish at T.C.D., was a member of the Irish Society. Foley, People and Institutions, pp. 25-9; Daniel Foley, A Missionary Tour through the South and West of Ireland, undertaken for the Society (Dublin, 1849). See also Henry McManus, Sketches of the Irish Highlands: Descriptive, Social, and Religious with Special Reference to the Irish Missions in West Connaught since 1840 (Belfast, 1863), p. 237; B.N.L., 9 Apr. 1858.

115 See chapter two above.

116 F.J., 3 Oct. 1866.

117 B.N.L., 22 Nov. 1859; although support from this quarter fell throughout the 1850s. Moffitt, Society for Irish Church Missions, pp. 108-70.

118 Moffitt, Soupers, p. 100.

119 Anon., 'Ireland as it is' in Presbyterian Magazine, i (Feb. 1859), 25-6. See chapter one.

120 Andrew R. Holmes, 'The Ulster revival of 1859: cause, controversies 
and consequences' in Journal of Ecclesiastical History, 63:3 (July 2012), 488-515; Achill Missionary Herald and Western Witness, 16 Mar. 1858.

121 P.R.O.N.I., Montgomery papers, D 2794/1, letter from John Montgomery, Portadown, to Joseph Searight, USA, 29 Apr.1858; William Gibson, The Year of Grace: A History of the Ulster Revival of 1859 (Belfast, 1860), pp. 15-16; Hempton and Hill, Evangelical Protestantism, pp. 159-60.

122 David N. Livingstone and Ronald A. Wells, Ulster-American Religion: Episodes in the History of a Cultural Connection (Notre Dame, 1999), p. 21; Richard Carwardine, Trans-Atlantic Revivalism. Popular Evangelicalism in Britain and America, 1790-1865 (London, 1978), p. 172; David W. Miller, 'Religious commotions in the Scottish diaspora: a transatlantic perspective on 'evangelicalism' in a mainline denomination' in David A. Wilson and Mark G. Spencer (eds), Ulster Presbyterians in the Atlantic World: Religion, Politics and Identity (Dublin, 2006), p. 36.

123 Malcolm P. A. Macourt, 'The religious inquiry in the Irish census of 1861' in I.H.S., xxi:82 (Sep. 1978), 168-87.

124 News cuttings and correspondence in the Larcom papers for 1860-61 show the level of Anglican anxiety over what the census might confirm or rebut. N.L.I., Larcom papers, Ms 7,750, News cuttings book 'Census, 1861 '.

125 A. T. Lee, 'Some account of the property and statistics of the church' in Essays on the Irish Church by Clergymen of the Established Church in Ireland (London, 1866), pp. 238-42; Hume, Results of the Irish Census of 1861, p. 43; W. C. Plunket, The Church and the Census in Ireland (Dublin, 1865), p. 3; Alfred T. Lee, Facts Respecting the Present State of the Church in Ireland (Dublin, 1865), p. 8.

126 James Begg, The Proposed Disestablishment of Protestantism in Ireland: Its Bearings on the Religion and Liberties of the Empire (Dublin, 1868), p. 31; See also Henry Cory Eade, 'The census' in Christian Examiner, new ser., iii:32 (Aug. 1861), 213.

127 Irish Church Directory (1868), 5.

128 Anon., A New Song on the Emigration of the Ministers (Dublin, c. 1869).

129 Larkin, 'Devotional revolution', 644.

130 Hynes, Knock, p. 100.

131 Cara Delay notes a curious moral dilemma presented in the confessional to John O'Sullivan which was itself solved by the emigration of one of the protagonists. Cara Delay, 'Confidantes or competitors? Women, priests, and conflict in post-Famine Ireland' in Éire-Ireland, xl:1-2 (Spring/Summer 2005), 112-13.

132 For an example of an almost comical, failed attempt at this type of bargaining, see Martha Kanya-Forstner, 'Defining womanhood: Irish women and the Catholic Church in Victorian Liverpool' in Immigrants and Minorities Special Issue The Great Famine and Beyond Irish Migrants 
Population, providence and empire

in Britain in the Nineteenth and Twentieth Centuries, xviii:2-3 (1999), 172.

133 P. Gannon, 'A sidelight on souperism' in Irish Monthly, li:595 (Jan. 1923), $16-18$.

134 Connolly, Religion and Society in Nineteenth-Century Ireland, p. 54; Connolly, Priests and People, p. 278.

135 Fitzpatrick, 'The disappearance of the Irish agricultural labourer', 66-92.

136 I.C.R.A., Cullen papers, CUL/1740, letter from Miley to Cullen, 4 May 1849.

137 Ibid., CUL/NC/1849/23, letter from D. Murphy to Cullen, 7 Oct. 1849; see also Ibid., CUL/1717, letter from Higgins to Cullen, 22 Feb. 1849.

138 I.C.R.A., Kirby papers, KIR/1863/101, letter from Leahy to Kirby, 27 Mar. 1863; Ibid., KIR/1865/172, letter from J. O'Leary to Kirby, 28 July 1865.

139 F.J., 4 June 1860; Dublin Evening Mail, 4 June 1860.

140 Anon., 'From our Connaught correspondent' in Irish Presbyterian, ii:21 (Sep. 1854), 162-3.

141 I.C.R.A., Kirby papers, KIR/1884/402, letter from McGettigan to Kirby, 24 Oct. 1884. 


\section{5}

\section{The spiritual empire at home: emigration and the spread of Irish religious influence}

The idea that mass migration from nineteenth-century Ireland created an Irish 'empire' has had enduring appeal. It proved a rare source of pride during depressed periods in independent Ireland, particularly the 1940s and 1950s, and provided the basis of an evocative title for at least one popular version of the Irish diaspora's story as late as the turn of this century. ${ }^{1}$ In the latter context especially, 'Irish empire' can appear simply a wry play on a far more common and not unrelated phrase - 'British empire.' ${ }^{2}$ Yet as many historians of Ireland, its diaspora and particularly the Irish Catholic Church have noted, the existence of a peculiarly Irish 'spiritual empire' was widely spoken of even as the country's ports remained choked with emigrants. This concept, normally involving the perception of a special, God-given emigrants' 'mission' to spread the faith in whatever part of the world they settled, is somewhat problematic given the practical limitations explored in chapter three. Nevertheless, as a continually employed explanation of Irish emigration, and one which was very nearly the sole preserve of clergy, it merits dissection here.

Curiously, while historians in the groups mentioned above allude to the prevalence of this line of thought, there have been few sustained attempts to analyse it. ${ }^{3}$ For many historians encountering the 'spiritual empire' thesis in the context of migration and the diaspora, its expression can be quickly dismissed as 'unrealistic' posturing, or as a merely 'compensatory discourse' which formed a more 'comforting' counterpoint to angry and generally futile pulpit denunciations of the causes of continuing emigration. ${ }^{4}$ Kerby Miller places it among the 'ambivalent rationalizations' of emigration offered by Catholic and nationalist commentators, a range of interpretations which he regards as secondary to his overarching 'exile' motif and consequently he gives 
it much less attention than it deserves. ${ }^{5}$ In the historiography of Irish religion, meanwhile, the 'spiritual empire' is an entity more usually and narrowly associated with the Cullenite takeover of Catholic Church leadership in the English-speaking world - what has been variously termed an 'Irish episcopal invasion' and 'Irish episcopal imperialism' - and with the staffing of its lower echelons with a stream of Irish priests and religious orders. In such readings, lay emigrants can often appear as mere background actors, their scattering, whether directly or indirectly, allowing the creation of new dioceses in which Paul Cullen could then have his Ultramontane acolytes installed as prelates. ${ }^{6}$ There is, also, a third category of cultural-historical analysis which places the idea firmly in a continuum of confident, anti-modern Catholic thought which began in the 1860s, reached its first peak during the cultural revival period towards the end of the nineteenth century, and its second in the middle decades of the twentieth. ${ }^{7}$ This, as we shall see, substantially misdates the emergence of the idea.

A merging of Irish migration and religious history therefore demands a more detailed and focused treatment of what was a longrunning and widespread facet of the clerical discussion of emigration. While Sheridan Gilley's pioneering work in the area argues that 'the creation of an international Catholic Church through the Celtic diaspora in the British Empire and North America' was 'quite the most remarkable achievement of nineteenth-century Ireland', this assertion opens an article which is focused primarily on the creation of an 'international consciousness' among Irish Catholic emigrants. ${ }^{8}$ The roots of the 'spiritual empire' concept and its effects on Ireland itself - in other words the Irish spiritual empire 'at home' - remain largely untouched. This chapter will therefore address the matter in these terms. It will look firstly at the set of ideas that lay behind the concept of a special emigrants' mission. It will then trace the development of its expression and any challenges to it - including parallel evocations of the concept from Irish Protestant clergy - before finally examining some important practical consequences of emigration and the 'spiritual empire' for the Irish churches.

'The notion of Ireland as a lever of transformation in the wider world,' as Declan Kiberd has noted, had considerable currency in late nineteenth- and early twentieth-century Ireland. ${ }^{9}$ W. B. Yeats and Padraig Pearse were exponents of the idea in the cultural sphere, but there were also secular versions from such diverse figures as James Connolly, who registered a hope that 'Irish apostles of Socialism' 
would exercise their influence in America, and Sir William Wilde, who asserted that 'the manifest destiny of the Celtic race was being fulfilled - to spread the English language, and carry the Irish heart, bravery, and poetry throughout the world. ${ }^{10}$ The belief that Ireland, through her considerable diaspora, exercised a disproportionate influence in the world, despite her modest size and her oppressed and persecuted position, functioned as a source of hope for many who sought for it vainly elsewhere. To some, it showed what the Irish would be capable of given self-government; hence the numerous paeans to the Irish abroad which appeared throughout the nineteenth century and beyond, detailing the towering achievements of Irish politicians and businessmen in their adopted homes. ${ }^{11}$ Such secular success stories, tempered as they were by widespread knowledge of the more mundane and often precarious fates of most Irish emigrants, were the least of it, however. Religious commentators had begun offering a more unambiguously glorious narrative some time earlier.

Broadly speaking, this narrative involved the interpretation of mass emigration from Ireland as the fulfilment of a specific, divine 'destiny', which had been specially accorded to the Irish 'race'. God had chosen the Irish to be, in a repeated phrase, a 'martyr nation' ${ }^{12}$ whose millions of exiled children were to form the faithful core of new congregations and dioceses of the Catholic Church wherever they settled around the world. That, as Mathew noted to his secretary on a visit to North America, included virtually everywhere. He saw the peculiar scattering of the Irish, as compared to the concentration of other European immigrants, as a function of their providential destiny. ${ }^{13}$ Indeed, to many, this was primarily a mission of the laity, only later supported (imperfectly, as we have seen) by the formal structures of the church. As the occasionally hibernophobic American Catholic commentator Orestes Brownson pointed out:

What is peculiar in the modern missions of the Irish [...] is that the people precede the pastor. They go out from Ireland as soldiers or as laborers, and wherever they go they carry their faith and devotion to the church with them. The priest soon follows them, and the nucleus of a Christendom is formed. ${ }^{14}$

This, as Brownson implied, contrasted with Ireland's earlier missions, the medieval 'golden age' when Columbanus, Colm Cille, Aidan and other Irish monks had founded significant early Christian settlements across Europe. Nonetheless, their efforts seemed to offer compelling 
parallels with the present. They showed, in the words of the eminent orator Fr Burke, that 'the Irish exile is a name recognised in history. The Irish exile is not a being of yesterday or of last year. ${ }^{15}$ Migration had always formed an integral part of Ireland's identity and place in the world, and it had also had a specifically religious purpose. The efforts of Columbanus et al. might even suggest that such evangelism came naturally to the Irish. Moreover, antiquarian interest in these stories had lately reintroduced them to modern readers as glorious figures who, through their exile, had made an evidently lasting impact on the world. ${ }^{16}$ Acknowledged by both Irish and European churchmen, this appeared to give every reason to believe that time would reveal a similar higher purpose to the contemporary exodus.

This was, however, just the first of a timely confluence of circumstances which seemed, from mid-century, to lend plausibility to the 'spiritual empire' thesis. The second involved further self-congratulation. It was repeatedly asserted that Irish Catholics had proved themselves 'inviolably attached' to their religion, and capable of retaining their faith through centuries of challenges. ${ }^{17}$ Most recently, neither penal laws nor opportunistic proselytism had swayed anything more than a small minority away from Catholicism. As Cardinal Gibbons of Baltimore observed of the Irish, 'no other people ever suffered for their Catholic faith as they'. ${ }^{18}$ This, many commentators felt, put Irish Catholicism on a higher plain. A Donnybrook priest told his congregation in 1850, 'There is not such a religious people on the face of the earth - so attached to their faith - so attached to their clergy.' ${ }^{19}$ The strength and resilience of Irish faith was matched by its ancient 'purity'. Michael Phelan, an Irish-Australian Jesuit, noted that 'Ireland had never belonged to the Empire of the Caesars' and thereby cut off, had been 'saved from its corruption and final ruin'. In an 1862 pastoral letter, Paul Cullen observed the spreading by emigrants of 'the faith which they inherited from St Patrick, and which had been handed down to them pure and uncontaminated by their fathers.'.

Such an exemplary form of religion was one not merely deserving of propagation, but one that could adapt to any climate, however harsh. One Irish-American bishop attested that the Irish were 'brave by nature, inured to poverty and hardship, just released from a struggle unto death for the faith', making them, 'of all the peoples of Europe' the 'best fitted to open the way for religion in a new country. ${ }^{21}$ Moreover, the very experience of persecution would itself be unique preparation for what lay ahead. As the Jesuit Auguste Thébaud wrote: 
Suppose the Irish never to have been persecuted in their own country: suppose that they had found there a benevolent government to supply them with churches, schools, hospitals, homes for the poor [...] how bitterly would they have felt the inconvenience of building all these things up for themselves in their new homes with the labor of their own hands, by their own individual efforts, unaided by the government! [...] persecution had admirably fitted them for the mighty work that lay before them. It was the first time for centuries that they were allowed to give for such sacred purposes. ${ }^{22}$

Thus, a tested faith, one which had withstood constant attack, commentators appeared to say, was eminently placed to take on both the many difficulties and the new freedoms which a world-wide mission would present.

The third apparently favourable circumstance also concerned a particular quality of the Irish, related to the second but harder for the modern sceptic to dismiss. By the advent of the Famine the ability to speak English had become a prerequisite of social advancement in general, and of emigration in particular. ${ }^{23}$ William Wilde may have thought Irish emigrants were thereby destined to spread the English language, but Catholic commentators saw it merely as a medium for conveying another cultural export. Ireland, it was noted, had an exceptional status as the only English-speaking Catholic country in the world. The implication was obvious. As Dr O'Brien of All Hallows observed in 1854, 'all the nations and dependencies which speak the English tongue, ha[ve] only Ireland to save them. ${ }^{24}$ 'The children of St Patrick,' his college's annual asserted, 'are the missionaries of the English-speaking population of the globe. ${ }^{25}$ Given that 'the English tongue [was] becoming the world language', Ireland's vital global importance to the Catholic cause was apparent. ${ }^{26}$ Cardinal Newman hit upon the heart of the matter when he noted that 'The English language and the Irish race are overrunning the world.. ${ }^{27}$ This, he implied, was no coincidence.

On the point of language, it is curious to note that, as Patrick O'Farrell does, that the notion of an Irish religious destiny was especially popular among Irish scholar priests of the Gaelic Revival, ${ }^{28}$ the otherwise lamentable fact that English had superseded the native language could be painted in positive terms. A sermon by an unnamed Co. Antrim cleric, which greatly impressed the editor of the Irish Monthly in 1887, elaborated: 
But surely it is some consolation for the loss of our language and of many other things that thus we are enabled to turn into an agent for the propagation of God's church, that language which is at present the chief medium of communication between the civilised races of mankind, and whose world-wide ascendancy is certain to be increased in every successive generation. [...] The language of Shakespeare, so copious, so pliable, and so strong, is not all given over to the service of heresy, scepticism, infidelity, and modern Paganism. English with an Irish accent has been the medium of some of the noblest bursts of eloquence and of some of the sweetest strains of poetry; and in another sphere, the most fervent prayers that ever went up from earth to heaven..$^{29}$

Rev. P. S. Dineen later extended this idea in his own interpretation of 'the world-wide empire of the Irish race', when he suggested that a combination of religious fervour and a uniquely Irish 'oratorical genius' were key to its success in spreading the church abroad. ${ }^{30}$

This third element was in turn linked to the fourth, for if English was the emerging world language, it was in part because England was the emerging world power. Indeed, it was widely understood, as English Oratorian Frederick Faber pointed out to Irish congregations in 1852, that 'The destiny of Ireland is common with that of England. She whose mighty empire extends over the globe, and upon whose realm the sun never sets.' 'The very tide of emigration flowing from [Ireland's] shores' bore the Gospel to the remotest extremes of the earth through England's colonial possessions, and indeed to England itself. ${ }^{31}$ Britain and her empire were to be construed, therefore, as the means through which an alternative Irish spiritual empire might be forged. That process began at home, where the injuries - and even the occasional blessings - of British rule encouraged emigration. The English Jesuit George Porter, speaking in 1864, could see in almost every piece of English legislation enacted in Ireland the hand of God preparing and spurring forward the Irish nation for its mission. National education had 'fitted the peasant for the work he was destined for'; the Encumbered Estates Court had 'enacted the most glorious revolution' which attracted 'a new set of landlords, who cared not for the peasantry, and who drove many thousands forth from this land'; the unchecked Famine had seen emigration intensify. 'Look at the cause,' he said, 'and see how God had used the mind and government of England and the instincts of men for his own ends. ${ }^{32}$

More common was a sense that 'The very ambition and desire for gain which impel England to extend her power and plant her colonies 
in the most distant countries of the globe, become the instruments for carrying also the undying faith of Ireland to the regions which England has conquered..$^{33}$ In Ireland, as Bartholomew Woodlock claimed in 1863 before the Catholic University opening session, 'the haughty Protestant mistress of the seas' had 'an humble Catholic handmaid. ${ }^{34}$ This, once more, was deemed a deliberate design of Providence. Indeed, it was only, according to Michael O'Connor, 'because of the higher role God wanted her to play in making way for the Irish to spread their faith' that England had been allowed to acquire an empire at all. ${ }^{35}$ Such thinking had its ancient allegories, Auguste Thébaud explaining that the Irish would accomplish the spreading of the Gospel in distant regions 'without a navy of their own'. Rather, 'as their ancestors did in pagan times, they would use the vessels of nations born for thrift and trade; the stately ships of the "Egyptians", would be used by the "people of God"."

Thébaud's reference to English 'thrift and trade' was pointed, intimating that, in this line of thought, Britain's empire was one of venal materialism and unchecked cruelty, which stood in unfavourable comparison - rather than in loose union - with Catholic Ireland's more noble empire of the spirit, 'cemented by racial sympathy and love. ${ }^{37}$ For the popular Cork novelist, Canon Patrick Sheehan, this contrast spoke of Ireland's fundamentally Christian ideals of humble self-sacrifice. 'Ireland will never rank amongst the great powers', he wrote in 1887, 'Neither would I desire it [...] And, surely, there is no true Irishman who would not rather see your harbour ploughed by the emigrant ship, carrying your evangelists over the world to those who sit in darkness and the shadow of death, than to see its waters blackened with the hulls of warships crammed with deadly instruments of destruction for the annihilation of the weaker nations of the earth. ${ }^{38}$ Ireland may have been one of those 'weaker nations', Sheehan proclaimed elsewhere, but Irish emigrants were bound to follow the mightier nation and establish 'a spiritual empire coterminous with that political empire. ${ }^{39}$

If it was 'coterminous', it was also greater - in extent as well as purpose. Certainly, the fact that the chief destination of Irish emigrants was in itself a separate, and increasingly powerful empire of capital was a point not lost on Irish Catholic rhetoricians of a particularly nationalist bent. Fr Thomas Burke, as recent work has shown, 'envision[ed] a Catholic empire in North America with a decidedly Irish character. ${ }^{\prime 0}$ Others saw in the United States, especially, the 
coming revenge for English misdeeds. Fr Daniel Cahill was fond of expounding on England's folly in causing the displacement of so many Irish to the United States, where their voices were being raised in Ireland's favour. 'Even now', he noted in 1853, 'if you will be quiet, you can audibly distinguish the shout of joy raised by seven millions of our blood, and our race, and our faith, all along the free shores of glorious hospitable America. ${ }^{31}$ Indeed, Cahill was among those who dreamed of the United States one day annexing Ireland. ${ }^{42}$ Such thinking clearly pre-figured the emergence of the Fenians from among the diaspora and their powerful motivating factor of 'revenge for Skibbereen' or the belief that Irish America would, in one emigrant's words, pay the British government 'a just reward for their oppression. ${ }^{43}$ While this idea had its providential element - the cry of 'God save Ireland', after all, belonged to the Fenians as much as anyone else - it also had a more overtly religious parallel, wherein the mistakes and iniquities of England would be answered not by a military or a political revenge but by a spiritual one. Irish Catholic emigration, lamented though it was, would ultimately prove to be the bane of Protestant England's empire. In Cullen's fire and brimstone description, God, through the dispersal of the Irish people and all that this was destined to entail, was 'confound[ing] the counsels of the wicked, and turn[ing] the arts of the children of darkness against themselves. ${ }^{34}$

It ought to be noted that the idea that an essentially political and commercial empire could also be used - indeed, was divinely designed to be used - for higher, religious purposes was not original. Even as Catholics made such claims for Ireland, British Protestant missionaries were everywhere striving to prove their own version. ${ }^{45}$ How to explain, as Stewart Brown has elaborated, 'that the inhabitants of a group of islands off the northwest coast of Europe had come to exercise dominion over such vast territories and hundreds of millions of non-Christians', if not that they had been 'chosen by God' to do so ${ }^{26}$ As historians have lately demonstrated, however, the relationship between 'the bible and the flag' - between Protestant missions and empire - was a highly complex one. Missionaries sometimes ran ahead of secular imperial expansion, or moved into areas the empire would never reach; they often objected to its worst excesses; and they did not always act as enthusiastic 'agents of empire' to the degree that is sometimes popularly imagined. 'Religion versus Empire', to address Andrew Porter's question, may be a step too far, but at the very least, there was often an uneasy alliance between secular and 
religious British overseas expansion. ${ }^{47}$ Nonetheless, the notion that God had given Britain its empire for the purpose of Christianising the globe was widespread among British Protestants from at least the eighteenth century, and could be expressed whether or not one agreed with all the secular pursuits of imperialism. ${ }^{48}$ In an odd sense, it is the kind of Irish Catholic rhetoric just discussed which most clearly demonstrates this fact.

The question of how Irish Protestants figured in all of this is therefore an interesting one, and ought to detain us here at least briefly. Two competing propositions present themselves. Firstly, did commentators from each (or either) denomination match Irish Catholics in claiming that their lay emigrants were instrumental in creating specifically Irish 'spiritual empires' of their own? Or, secondly, was the Irish Protestant diaspora as easily assimilated into a broader British narrative in such rhetoric as it apparently was on the ground in the colonies? ${ }^{49}$ There appears relatively little evidence of the former in the case of the Irish Presbyterian and Anglican churches. ${ }^{50}$ Invocations of Ireland's medieval missionary past can be found, but are much less frequent than in Catholic commentary, and generally refer to the work of missionary societies and their agents rather than to lay emigration. ${ }^{51}$ If some Irish Protestants did see a particular religious role for their migrant brethren, it was a familiar one; given their experiences in Ireland, they were deemed especially well equipped to act (though in unspecific terms) as a bulwark against 'disloyal' Irish Catholic designs on the empire, of which the Protestant churches clearly were not unaware..$^{52}$ As Orange Order histories attest, Irish Protestant migrants could number among the most enthusiastic proponents of an empire that they particularly held to be a bastion of 'distinctive Protestantism', and those left at home were conscious and proud of a vibrant 'Orange world' - which was, however, neither exclusively Irish nor specifically 'spiritual' - within that empire. ${ }^{53}$

The Irish Protestant diaspora was, therefore, interpreted as being very much inside the British empire, patriotically contributing to 'the imperial nationality', rather than disloyally using it as a foundation on which to construct its own alternative Irish spiritual empire or empires. ${ }^{54}$ Protestant Irishmen, Church of Ireland bishops asserted, were 'integral' to the empire's spread of 'civilisation and religion', operating 'side by side with their English brethren. ${ }^{55}$ Like these brethren, however, Irish Protestants could also offer critiques of some of the more distasteful facets of imperialism. The Ulster Presbyte- 
rian minister John Brown, for example, noted as early as 1865 that while the colonies offered protection to Protestant emigrants who were 'the most powerful means of diffusing the Gospel', the 'unjustifiably severe' treatment of their 'aboriginal inhabitants' ought to be condemned. ${ }^{56}$ In that sense, the Protestants of Ireland viewed their providential mission to spread the faith as a joint enterprise with the sister island, and saw it in the same, sometimes conflicting terms as English, Scottish and Welsh Protestants did.

Thus, there was little that was distinctively Irish about Irish Protestants' conceptions of a 'spiritual empire', except perhaps that when occasion eventually called for it, the role of the Irish Protestant was put to more overt political use than may have been the case for the rest of the United Kingdom. The 'empire card', according to one analysis, was the second most popular argument used against a Dublin parliament during three Home Rule crises. ${ }^{57}$ The churches, particularly the Church of Ireland, made their share of the plays. ${ }^{58}$ One minister, still smarting from disestablishment, warned William Gladstone in 1882 that the empire was at risk if he continued to ignore the Protestants of Ireland, who were, he noted, 'destined to take a noble part in transmitting the light further westward' via the rising American empire, if not via the British. ${ }^{59}$ As alluded to in the previous chapter, Presbyterian commentators had likewise long looked to the United States to fulfil any notions of a religious 'destiny', although it was arguably a more mutually cooperative, transatlantic exchange of ideas that they saw themselves engaged in, than the singular, exclusive mission Irish Catholics had assigned to themselves. ${ }^{60}$ Indeed, Hempton and Hill have noted that Irish evangelicals 'could think of themselves either as a faithful remnant of righteousness in a pagan land or as part of a great and civilising world empire', 'depending on circumstances. ${ }^{61}$ At least insofar as the emigration of their own congregants went, circumstances did not seem to demand that Irish Protestants construct a providential narrative as complex, multi-faceted, and pervasive as the one invented by their Catholic equivalents.

Catholics, therefore, had a set of apparently cogent reasons to believe that mass migration from Ireland was part of a divine plan. History, a much-vaunted purity and strength of faith in the face of persecution, knowledge of an increasingly universal language, and the opening up to a great stream of Irish emigrants of empires both political and mercantile, appeared to have converged in timely fashion to create a perfect missionary storm. A modern, secular perspective 
might find obvious problems with this thesis. While the characterisation and dismissal of it as unrealistic by some scholars is understandable, that fails to take account of how persuasive these accumulated factors, continually recited in sermons, lectures and public journals, must have appeared to those of genuine faith. After all, as Sheridan Gilley has observed, Catholicism has at its core a belief that 'all men are exiles, poor banished children of Eve' whose lives had a destiny to fulfil in getting to heaven. ${ }^{62}$ It was not such a great theoretical leap from this accepted individual assignment to a more general national or tribal 'calling' exercised through mass outward migration. Misguided or not, the belief had tangible consequences and simply alleging a lack of realism for this explanation of emigration somewhat misses the point.

Similarly, the straightforward impression that the notion of a 'spiritual empire' served to comfort or compensate for the diminution of flocks at home, though certainly true in part, also tends towards simplification and a disallowance of genuine religious belief. The clear implication is that this was a concept consciously invented for that purpose alone, and that an element of self-delusion at best, or, at worst, cynicism lay behind its repeated espousal. Certainly, there are reasons to suppose that either may have been the case. There can be no doubt that the idea of a God-given mission was sometimes a convenient rhetorical weapon to deploy. In certain contexts, it was used to boost self-esteem - news reports suggest that it could be relied upon to reap cheers and applause at public gatherings - to distract from empty pews at home, and even to indemnify those home losses. On one occasion in 1852, for example, Cullen told the French Catholic newspaper L'Univers, from whose readers he had received aid to fight proselytism and the causes of emigration, that 'One sole reflection is able to fortify us - it is, that those emigrants without number who quit our shores, or who are inhumanly driven from them, are destined to raise the standard of the cross in distant countries, and to carry the light of the Gospel to nations seated in the shadow of death. ${ }^{3}$

It is also possible to speculate that another calculated interpretation was being developed. As discussed in Chapter Four, many Protestant commentators from the Famine onwards delighted in believing that most emigrants' Catholicism barely lasted the Atlantic crossing and would leap on any and all public hints from Catholics concerned about the spiritual destitution of the diaspora to confirm as much. To counter these suggestions, the construction of a matching propaganda, 
involving an entirely different providential plan for Irish Catholic migrants, would have held an obvious attraction. While that may occasionally have been the case, the Catholic thesis would arguably have developed and taken hold regardless. As has been seen, the more usual and reasonably effective Catholic response to such Protestant rhetoric consisted of a non-engagement with it: it was either quietly ignored or acerbically ridiculed. Therefore, the notion of an Irish Catholic 'spiritual empire' cannot be seen as simply a cynical reaction to Irish Protestant claims of the opposite.

Proof of the sincerity of the belief in a higher purpose to emigration can, moreover, be found in its private expression. More than one letter to Dr Kirby at the Irish College, Rome employed such language specifically to explain the continued outflow. The Waterford Christian Brother M. P. Riordan wrote in 1847 that 'such of the people as have a trifle of money are mostly emigrating to America, and tens of thousands are going to England [...] God has his own wise ends in my view, and will, doubtless, turn this pressing calamity to our advantage. ${ }^{64}$ In 1863, a Waterford curate, George Commins, complained that the exodus went on despite apparently good harvest prospects. It was, he said 'most alarming and melancholy', that 'every day the peasant class are leaving our Quay and no longer with that wild expression of sorrow with which they were accustomed to leave poor Ireland some years ago, but with the stolid coolness of men who have grown weary of the striving and poverty of home'. Still, he felt, 'Providence no doubt has his own wise ends in this and has chosen them as instruments for a great work viz. of carrying the faith into all parts of [the] world. ${ }^{65}$ The following year, the president of St Colman's College in Fermoy speculated similarly that despite the 'Sixty four thousand people [who] left Queenstown by one line of boats, between the January of '63, and the January of '64', a figure he described as 'terrible,' 'we must only hope and believe, notwithstanding, that Providence has something good in store for us yet.'.6

Stripped of its public bluster, the notion of a special providential mission of the Irish appears for the theodicy it essentially was. It represented the obvious and, on their terms, rational response of the pious to a dispiriting phenomenon which came to require, not simply condemnation in a political or economic context, but explanation in religious terms. Why would a merciful God allow such a terrible drain to occur otherwise? On that score, recourse to the notion of Ireland as 'the centre of a world-wide mission' came easily in the aftermath 
of the Famine, in part because it had existed in a nascent form before then, when, let us recall, emigration had been a much less controversial political and economic issue for many Catholic clerics. This had allowed the development of a definite, positive sense that Irish emigrants were helping form the nucleus of an infant and growing church in Britain, America and beyond, a fact only magnified when prelates in the American church increasingly had names that were distinctly Irish in origin. The newly formed Irish Association for the Propagation of the Faith pushed this line from its beginning, and one Dublin Review writer was moved to speculate in 1839 that, owing to emigration, both Irish and German, 'all America will be a Catholic country. ${ }^{\prime} 7$ Two years later, one of that journal's founders, Dr Wiseman, told an Irish audience that 'emigration ha[d] extended the influence of the church to distant countries.' ${ }^{68}$

What is more, two of the most prominent contemporary Catholic spokesmen in Ireland were making similar and even more explicit claims. As far back as 1840, Archbishop John MacHale had been quoted in the Annals of the Propagation of the Faith, claiming that 'England is suffering from Ireland the generous retaliation of the Gospel; for, by filling England with its industrious Catholic emigrants, our country is silently bringing that fine nation back to the yoke of the Gospel'. ${ }^{69}$ A year later, Daniel O'Connell reportedly told Fr James Maher that through emigration, 'Ireland is fulfilling her destiny - that of Catholicising other nations':

Wherever a few exiled Irish get together, the first thing they think of is, to procure the ministration of a priest for their little community. Thus a nucleus of Catholicism is formed, and the surrounding inhabitants are attracted; first by curiosity; then they are led to inquire; and, finally, several will end by embracing the faith. It is these little colonies of Irish who have largely helped to diffuse Catholicity through England. ${ }^{70}$

It was natural, therefore, that as the shock of the Famine sank in, the revival of this idea saw opinions of Irish influence on the church abroad inflated to match the hugely increased Irish population abroad. Indeed, German and French Catholic migrants, often mentioned alongside the Irish before the Famine, tend to go uncredited in such discourse after it. The unprecedentedly extensive exodus from Ireland which began in 1846 really seemed to many to speak of an unprecedentedly extensive - and exclusive - Irish mission. This could seem an empty boast in certain contexts, but it was also the case that even 
certain public commentators protested an excess of pride in the idea of an Irish mission which, they emphasised, was a result not of 'the workings of human prudence or human power, but the strong hand of a merciful God'. ${ }^{71}$ If pride nonetheless seeped through, it was a pride in the Irish having been thus providentially 'chosen'.

How to square even this muted pride, however, with the parallel dismay at continued emigration which contemporaneously became apparent in public and private, from both priests and bishops? For many, there was no conflict. As the French priest Adolphe Perraud explained in his popular Ireland under English rule:

Considered individually, the moral and religious results of Emigration are frequently deplorable [...] If, on the contrary, we consider the Emigration movement as a whole; if our view embrace not merely its individual but its general consequences; we find ourselves in the presence of an admirable spectacle, and we cannot refrain from extolling that divine Wisdom which makes everything concur in the execution of its plans ... ${ }^{72}$

This distinction was important for a number of reasons. Firstly, it gave believers in a providential mission a way of explaining the well-known (if exaggerated) 'leakages' from the church abroad which clearly seemed to contravene it. Canon Sheehan, once again, put the issue in sacrificial terms. Though the people had to abandon their homes in Ireland, though many of them would lose their faith, especially in the second and third generations, though many were subject to anti-Catholic sentiment, and though all of this, indeed, caused the deserted Irish parish priest considerable anguish, there was a greater purpose. 'It is a sacrifice,' wrote Sheehan, 'but necessary.'73

Moreover, the dichotomy between the individual and the general allowed criticism of what were perceived as the immediate, tangible causes of the exodus - evicting landlords, neglectful government, religious persecution - to continue, even as these were being cited as elements of a divine plan to spread the faith. A trust in Providence did not dictate that all of its apparent exigencies had to be meekly borne. The variety of responses to the 'visitation of God' which the Famine seemed to represent perhaps serves as the best example of this. British and Irish Protestant charity towards the nation being 'punished' for its sinfulness may in one sense have defied that providential judgement, but it was also, for many, the proper Christian response to the suffering of individual humans. As the Belfast Presbyterian James 
Morgan preached, 'While humbled before God, we must be active and benevolent toward men. ${ }^{74}$ Equally, if John MacHale initially saw the Famine as 'no doubt a chastisement of the Almighty', he was also, like certain Protestant clerics, a vigorous critic of those government policies which he believed had hastened it and those which failed to deal adequately with its fallout. ${ }^{75}$ In the same vein, providentialist thinking helped to explain continued emigration, but it did not, as Monsignor Michael O'Riordan, a later rector of the Irish College Rome, was among those to point out, absolve of blame anyone deemed responsible for it and the individual suffering it frequently caused. ${ }^{76}$

There was some irony, therefore, that in much of this apostolic theorising, individual emigrants could appear, more even than in economic theory, as mere ciphers for certain commentators' grandiose visions. Just as economists had claimed that emigrants would materially benefit themselves and Ireland by leaving, Catholic spokesmen said that emigrants and the wider world might benefit spiritually through the same process. If economists could then be criticised for seeing people as pawns to be moved about at will to fit an overarching game-plan, they at least spoke in the knowledge that most emigration did occur for economic reasons: people left Ireland either to escape crippling poverty or to achieve a betterment that was impossible at home. That made their claims for emigrants - and possibly Ireland seem plausible, if not entirely noble. Catholic commentators had to acknowledge, on the other hand, that emigrants did not leave with any intention of fulfilling a religious destiny. One of the earliest fulllength expositions of the 'providential mission' in the English Catholic journal The Rambler in 1853 described Irish emigrants as 'a band of unconscious crusaders,' who believed they left for material reasons, but were simply unaware of their true divine mission. Three years earlier, Dr O'Connell of Donnybrook had painted emigrants similarly as 'unaware of the noble end of their expatriation', and a Rev. Hegarty of Derry spoke of Ireland as 'the unwilling pioneer of the Catholic faith. ${ }^{77}$ As time went on and the idea of a 'spiritual empire' took hold, emigrants surely became aware of the supposed higher purpose of their departures, not least when faced in their new homes with St Patrick's Day sermons which lauded the mission of their race and with wildly popular literature, often written by clergy and squarely aimed at them, which explored similar themes. ${ }^{78}$ Moreover, even if Canon Sheehan was given to dismay in one novel that at home 'the idea of Ireland as a great missionary country is scoffed at', as David Fitzpat- 
rick has noted, letters from Ireland constantly boasted of the 'power and pervasiveness' of Irish Catholicism, and encouraged emigrants to match it. ${ }^{79}$ Nevertheless, there soon came criticism from various quarters of the Catholic thinking which seemed to resign emigrants to an earthly fate which, in Sheehan's admission, so often involved great suffering.

Archbishop John Joseph Lynch's 1864 circular The evils of wholesale and improvident emigration from Ireland was the catalyst for much of this criticism. The Toronto prelate's revelations of wretched poverty and criminality were bad enough, but his confirmation that many Irish immigrants had abandoned their faith, afforded, so the Fenian John O'Leary felt, 'a strong commentary upon a supposed saying of Archbishop Cullen's, that the famine of ' 45 was a dispensation of Providence, to drive the Irish abroad to spread the Catholic faith'. ${ }^{80}$ O'Leary's colleague, Charles Kickham, in welcoming Lynch's pamphlet was still more scathing, asking sarcastically, 'does not the bishop of Toronto know that it is our glory to be the martyr nation? It is [by] the mercy of Heaven that Irish men and women are wallowing in crime and misery from Quebec to New Orleans. ${ }^{81}$ Except that Lynch did know, of course. Only a year before, in a St Patrick's Day homily in Toronto he had unselfconsciously said as much, and he would say so again on several further occasions. ${ }^{82}$ His purpose in urging a stay on the exodus from Ireland was, as the title of his publication suggests, merely to prevent the 'improvident' emigration; to forestall the 'wallowing in misery' in cities and redirect emigrants towards the land. Such an outcome, he felt, would help them better fulfil their providential mission by avoiding quite so much temptation to immorality and apostasy along the way. ${ }^{83}$

It was not just Fenians who chose to misinterpret Lynch's point, however. As well as the usual Protestant seizure of any remarks that seemed to support their assertions of mass Irish Catholic emigrant apostasy, there were those within the Catholic Church who took his intervention as proof of the wrong-headedness of the entire 'providential mission' thesis. ${ }^{84}$ The most remarkable, full-throated expression of this sentiment came in 1864 from Patrick Durcan, Bishop of Achonry. Dedicating a church in Ballymote, Co. Sligo, his sermon turned, not unusually on such occasions, to the sad spectacle of continuing emigration from among the local population. His next reported words departed from the normal script, however: 
He might be told that the emigrants were the instruments of propagating religion in foreign countries. [...] Let people misrepresent this state of things as they choose [...] No doubt there might be benefits in this emigration to religion; but if there were benefits there were also evils, which were deplored by bishops in foreign countries, who adjured them to keep at home the sons and daughters of Ireland [...] he trusted he would never be one of those who would find in the Catholic colonisation of foreign countries an unfeeling and unprincipled apology for the Catholic desolation of their own. ${ }^{85}$

These strong words - subtly directed at many of his fellow bishops were matched a year later in a letter received by Dr Kirby from one of his former pupils. James O'Leary, a priest-professor at St Colman's College in Fermoy with Fenian sympathies, hinted that others shared his view when he told Kirby: 'The country is rapidly pining away. The people are going to America in numbers. [...] Fathers at home are saying that if the Irish are spreading the faith they likewise fill the brothels. ${ }^{86}$

Still others were rendered lukewarm towards the idea by Lynch's reminder of the less welcome religious consequences of emigration. O'Leary's bishop, William Keane of Cloyne, had once spoken in familiar, glowing terms of Ireland exercising 'a lay apostleship', 'sending forth her children to America and Canada, to England, and to all the colonial establishments of England. ${ }^{87} \mathrm{He}$ issued a decidedly more equivocal pastoral letter on the subject in 1865:

Of the emigrants who have left this country, some have preserved and some have lost their faith; some have preserved and some have lost their virtue. [...] Thus, while the priest has reason to believe to rejoice over the good which his Catholic countrymen are doing in other countries, he has reason and still greater reason, for the past and for the future, to weep over the ruins he cannot avert. ${ }^{88}$

On balance, Keane thought it best to attempt to keep as many young people as possible from running the risk of being among those ruins.

Lynch's pamphlet aside, it is unsurprising that the 1860s - far from providing the first signs of the 'spiritual empire' thesis - saw the first objections to what had previously been an unchallenged trope. Despite ongoing civil war in the chief destination, an agricultural depression meant emigration reached a ten-year peak of over 100,000 annual departures between 1863 and 1865, including an apparently sharp upturn in emigration from among the farming class. ${ }^{89}$ The latter 
especially prompted much hand-wringing among the Irish hierarchy, particularly in western and southern dioceses. ${ }^{90}$ Their renewed concern was reflected in the founding of the National Association in December of 1864, an attempt to fill a political chasm in danger of colonisation by the Fenians. Growing emigration, as Larkin has shown, was its other parent. ${ }^{91}$ If the former was Cullen's peculiar obsession, Patrick Leahy, Archbishop of Cashel, could take credit for mobilising opinion on the latter, having begun lobbying Cullen about the church taking a stand on the land question - which, as he and Cullen both believed, had emigration as its most serious effect - late in the previous year. ${ }^{92}$ As he told the 'aggregate meeting' which established the Association, it was the drain of the people from the land that 'has brought us bishops to the determination not any longer to remain quiescent. ${ }^{93}$

This drain, as Leahy told Kirby in March 1863, had one very serious potential consequence for Ireland and her Catholic Church:

If God in his mercy does not preserve to us a remnant of our people, in a short time the Protestants will outnumber us. For, mark you! - it is only the poor Celts, the poor Catholics, the beloved members of our flock that are going - not one Protestant, I may say. The Landlord and Tenant laws are rooting the Celtic population out of the land, as surely as any physical cause produces its effect - and this wicked Anti-Catholic, Anti-Roman, Anti-Irish, Anti-everything-dear-to-us-Government is looking on, laughing with delight, seeing that the direct, the certain effect of these laws is to root out our Catholic people, that in fact they are as effectual penal laws against our people as any ever enforced, and therefore they will not raise a little finger so as to change these Laws as at once to do justice to both Landlord \& Tenant. God help us. If he does not, I fear we are lost, as a Nation, as a Catholic nation. ${ }^{94}$

Leahy's gloom, if not his anger towards the government, was somewhat tempered by uncertain thoughts of a higher purpose to the exodus. In June he wrote the Bishop of Philadelphia asking: 'Great a calamity as is the dispersion of our fine people, would it not seem as if, in the views of Providence, they were a missionary people, destined, by their very dispersion, to scatter [and] broadcast over the earth the seeds of the true faith nurtured for ages in their own Island of Saints? Is it a consolation that God thus draws good out of evil?' 'But' he added, 'there is no excuse for the heedlessness and the heartlessness of the Government that will not try to correct the evil. ${ }^{95}$

In company with his fellow bishops, though not the Association as a whole, Leahy was subsequently given to 'temperate satisfaction' 
with the 1870 Land Act which was partially the result of their labours on this front. ${ }^{96}$ While it is unlikely that the Act really put the brake on emigration, it would seem that its implementation was sufficient for Leahy, at least, to invest more fully and more positively in the notion of a spiritual empire. ${ }^{97}$ A sermon he preached at the consecration of Dr Moran as Bishop of Ossory in 1872 saw him acknowledge that:

While we deplore as one of the greatest national calamities the loss of millions of our fine people, we are not left without some compensation for the loss, seeing that God, who knows how to draw good from evil, has built them up in other lands into a mighty people, or rather peoples, who, faithful to their country's traditions, have in every region of the earth to which they have gone, whether they be found on the banks of the Ohio, or in far-off Australia, or elsewhere, planted churches full of new life, and all in the closest connection with Rome. ${ }^{98}$

With the loss of 'the best of the people' apparently stemmed, the 'missionary' achievements of those who had gone were again ripe for glorification.

The Fenian criticism, and Leahy's mention of 'the closest connection with Rome' here prompt an obvious question: did belief in emigration as a providential mission correlate in any respect to the splits in the Irish hierarchy, whether defined as 'castle' versus 'patriot', Ultramontane versus Gallican, or, the inexact short-hand for both, Cullen and his allies versus MacHale and his? Notwithstanding that there were always figures on the episcopal bench who did not neatly conform to such simplified categories, the answer would appear to be no - and also yes. No, because although John O'Leary later damned the by then deceased Cullen with the charge that he had fostered 'no feeling about his country other than that it was a good Catholic machine, fashioned mainly to spread the faith over the world, ${ }^{99}$ and although the strongly nationalist sensibilities of his namesake, Fr James O'Leary, seemed similarly offended by the belief that emigration conformed to a specific dispensation of providence, ${ }^{100}$ that belief, as seen above, tended to be shared across otherwise intractable divides. To be sure, Cullen frequently resorted to the language of 'spiritual empire' in his pastoral letters and other public pronouncements, but so too did John MacHale. The Archbishop of Tuam was not averse to referring to Irishmen in America 'labouring to roll back the tide of Catholicity so long receding from its shores', nor even in his Lenten pastoral of 'Black ' 47 ', to 'the exiled children 
of Erin' having 'scattered the blessing of the Catholic religion over distant lands. ${ }^{101}$

Furthermore, for every supposed 'castle bishop' such as David Moriarty, who, understandably, given his former role at All Hallows, extolled the glory of the spiritual empire, ${ }^{102}$ there was a confirmed Cullenite like Laurence Gillooly of Elphin who mentioned emigration quite frequently in his public speeches and private correspondence around the time of its 1860s peak, but seems always to have refrained from any allusion to the exodus being providential - although he did not reject that idea outright. ${ }^{103}$ As to the only bishop who seems to have done so, Patrick Durcan's position on the episcopal spectrum, far from aligning him with like-minded ultra-nationalists, was one of relative moderation. He had been favoured for the see of Achonry in 1852 because he was (rightly) thought not to be a slavish MacHale supporter, but neither could he have been regarded as a Cullenite. ${ }^{104}$ Therefore it is clear that espousal or rejection of the idea of a special religious purpose to Irish emigration could not serve as a litmus test for any other 'political' viewpoint so far as the hierarchy was concerned.

It may be, however, that advocacy of the idea did gradually develop into a more explicitly 'Roman' impulse. Clear though MacHale's pronouncements were, they seem to have tailed off by the mid-1850s, even though there can be no question that he was aware of the continued and increasing potency of the notion. Certainly, on at least two occasions, he found himself at public meetings where other speakers spoke of Irish emigrants as 'God's appointed missionaries. ${ }^{105}$ It is difficult to know how to interpret MacHale's later silence on this point, but it is worth noting that like other prelates, including Cullen, MacHale was especially given to eulogising Ireland's special missionary status while speaking in support of the Catholic University. ${ }^{106}$ His subsequent opposition to Cullen's control of that institution meant, as Colin Barr has noted, that he 'remain[ed] an enemy of the C.U.I. from around 1854-55 to 'the end of his days. ${ }^{107}$ Thus, while it is odd that such a voluble figure would not, like Bishop Durcan, have publicly objected had that been his inclination, it may be that the increasingly 'Hiberno-Roman' character of the Irish spiritual empire - and its domination by Cullen - rendered it less attractive and less useful to MacHale.

What, then, of O'Leary's specific charge against Cullen? Regarding the more general point that he had 'no feeling about his country', 
others must judge. ${ }^{108}$ The implication that he dehumanised emigration and saw it merely as a convenient means to an end - that end being a Romanised global church - seems like the casual slur of an implacable opponent. In fact, there was much more common ground between the Fenians and Cullen on emigration than either O'Leary or Kickham were prepared to acknowledge. As Paul Bew has correctly noted, certain passages on poverty and emigration in Cullen's pastoral letters read as though lifted straight from the leader column of The Irish People, ${ }^{109}$ a function of Cullen's genuine distaste for the economics of landlordism and the failure of the government to arrest its evils. ${ }^{110}$ Furthermore, in private, Cullen often expressed his sadness at the continuing exodus, even if, as Larkin notes, he was less given to 'hysteria' on the subject than most. ${ }^{111}$ In 1864 he told Kirby, perhaps his closest confidante, that, 'We have beautiful weather and everything is looking well but the people are running away every day. God help them. ${ }^{112}$ In the same year he wrote Moran that 'the people are running away to America very fast [...] It is a sad state of things. ${ }^{113}$ Cullen frequently despaired at his inability to stop the 'emigrants who are going out or wishing to go - I could say nothing to them. ${ }^{\text {'14 }} \mathrm{He}$ also worried for their welfare once abroad: Lynch's circular appeared genuinely to touch him, and, unsurprisingly, he deemed that the Fenians had 'done great harm to the poor Irish workmen and servants in England, who were being turned away from work on account of their outrages. ${ }^{115}$

In any case Cullen was clearly not the originator of the idea that Irish emigrants were the agents of a providential mission, contrary to O'Leary's hazy, probably second-hand recollection. It is difficult to pinpoint who was. While McCartney and Steele each credit O'Connell with popularising the idea, they offer no evidence that he spoke about it publicly and it appears that Daunt's previously cited recollection, dated 1841, is their only source. ${ }^{116}$ Yet the concept was certainly sufficiently advanced by the late 1830s for Bishop England to desire to challenge it with his letter on Catholic leakages in the United States. ${ }^{117}$ Moreover, if there was a leading early advocate of the idea in the Irish Catholic hierarchy, it was John MacHale, given his 1840 statement that Irish emigrants were bringing about the conversion of England and his quick resort to similar sentiments during the Famine. It is important to note, moreover, that such hopes for England's conversion had been privately rejected at the time by a surprising figure: Paul Cullen. A visit to his family in Liverpool in 1842 had seen the then Rector 
of the Irish College observing to Kirby that scarcely one tenth of the Catholics in the city - most of whom were Irish - attended Mass. 'I fear', he said, 'that the talk of the immediate conversion of England is without the least prospect of becoming even probable. However, God can do as He likes. I think more lose the faith than those who are converted.' ${ }^{118}$ This was all, of course, before Cullen returned to Ireland from Rome to take up the primacy. However, it is fair to say that even after 1850 , he was certainly not the only proponent of the 'spiritual empire' thesis.

As an aside to that point, it is worth remarking on the extent to which the thesis was promoted by clergy outside of Ireland. If selfpraise is no recommendation, the reputed missionary endeavours of Ireland and its emigrants were sufficiently lauded by external commentators for no such charge to be brought against Irish clergy. Not surprisingly, it found particular expression among clergy and bishops of Irish origin or ancestry, and presented itself, as noted, as a popular and rather obvious theme of St Patrick's Day sermons in immigrant cities. ${ }^{119}$ Other Catholic writers also perceived it, however. The French cleric Adolphe Perraud, the French-American Jesuit Auguste Thébaud, and the highly influential Anglo-American convert Orestes Brownson, as has been seen, each wrote admiringly of the positive impact they believed Irish emigration had on the spread of Catholicism across the world. ${ }^{120}$

Moreover, English Catholic churchmen like the aforementioned Faber, da Haerne, Porter and Newman, along with Cardinal Manning of Westminster, also recognised the special destiny of 'the children of St Patrick'. According to his biographer, Manning 'was ever speaking of the great work the Irish people had done in spreading the faith. ${ }^{121}$ Indeed, the latter's own position as part of the restored English Catholic hierarchy had in part been made possible by the immigration into England of those very children. So enthusiastic was Manning for these sentiments that he was even invited to repeat them at the church of the Irish Franciscans in Rome on St Patrick's Day in 1879. ${ }^{122}$ That location highlights a notable exception to this general acknowledgement of a special Irish mission: the Vatican, whose incumbents surely deemed that they, rather than the Irish nation, presided over the worldwide Catholic 'empire', seems never to have offered any. While Popes Pius IX and Leo XIII were certainly aware of the idea of a special Irish mission, neither went so far as to approve it publicly, and each merely acknowledged the fortitude of the faith in Ireland. Given that 
both men had biographers of Irish ethnicity, it seems likely that any more concrete pronouncement would not have gone uncelebrated. ${ }^{123}$ Interestingly, Michael Davitt, of all people, intended to argue in an audience with Leo XIII that the existence of this mission merited the opening of diplomatic relations with Ireland. ${ }^{124}$ In the end however, he failed to get his audience with the same politically unsympathetic pontiff who condemned the Land League and was supposed later to have told Thomas Croke that he was 'not only the Pope of Ireland, but of the Universal church' and could not therefore 'sacrifice the church to Ireland'. 'Nor Ireland to the church', the archbishop claimed to have shot back. ${ }^{125}$

'Sacrificing Ireland to the church' was, returning to Cullen, the essence of the Fenian indictment of him. While he might be excused the charge of anything so heedless of the plight of the individual emigrant as O'Leary alleged, however, it is also clear that Cullen, both as Irish primate and as Barr's 'episcopal imperialist', was acutely conscious of the advantages to the worldwide church of the Irish outflow. This takes us back to Perraud's separation of the individual and the general consequences of emigration. Cullen's letter to Cardinal Barnabo of Propaganda Fide in the wake of the Archbishop of Toronto's circular, typifies this dichotomous response and is worth quoting at length:

I am sorry to say that the people are fleeing Ireland in great numbers. [...] The poor people go totally unprovided of the necessities of life, and then endure incredible misfortunes in America. Our government however does not give the least protection to these poor people. [...] If the King of Naples and the Pope had treated their subjects as the poor Irish are treated, England would have been full of indignation, and the English newspapers would have been hurling insults against the sovereigns who did not protect their people. They do not say a word however in favour of the Irish people, but so great is their hatred of the Catholic religion, that they appear to exult in the destruction of the poor people. It is clear that just now Ireland will lose a great deal, but I have the greatest hope that religion will not lose anything, the losses that we now suffer will be repaired. [...] Within the last three hundred years, the population was almost totally destroyed five or six times, however it always recovered again, and has demonstrated an amazing vitality. I hope things will turn out as they have turned out so many other times, that is for the present the Irish will form new Catholic congregations in England and in America, while Ireland will remain completely Catholic. ${ }^{126}$ 
There are several points to be noted here. Firstly, Cullen displayed an apparently genuine anger at the government and landlord policies which he believed caused emigration, a point he had also made to Barnabo before Lynch's pamphlet, and was re-emphasising here in light of the Archbishop of Toronto's mild admonition of the Irish hierarchy. ${ }^{127}$ Secondly, he seemed very firmly to believe that such policies were motivated by anti-Catholicism. This was in direct contradiction to what Kickham would later identify as the most important point from Lynch's pamphlet - the idea that 'a religious persecution would produce martyrs; but this social persecution and oppression of the poor ruins souls. ${ }^{128}$ For Cullen, the treatment of the Irish poor by the government was religiously motivated persecution, and to that end, its often terrible social consequences were to be regretted, and arrested where possible, but its religious consequences had to be regarded as the outworkings of Providence. Those outworkings were often positive, but where they were negative, they were no less providential, and as Canon Sheehan would later elaborate, they could be seen as the unfortunate elements of a necessary sacrifice, of the creation of a true 'martyr nation'. In Cullen's words to a gathering at Clonea, Co. Waterford later that year, 'The suffering which we as Roman Catholics have suffered from being in connection with England has made its recompense, we have been thereby able to confer the benefits of our holy religion on other countries. ${ }^{129}$

Finally, Cullen predicted, despite Lynch's warning, that emigration would entail no overall loss to the global church, and would, moreover, fail seriously to harm the church in Ireland in the longer term. This last point echoed the feeling of the Catholic journalist Martin Haverty, who had recently made the confident claim that 'Ireland will be Irish and Catholic still in spite of the exodus' and foreshadowed Archbishop Leahy's later belief that 'after the exhaustion of famine and emigration, we have yet millions to be the seed of a great people, and we thank God that we have no reason to fear for the future of our religion, but the contrary', which itself formed a stark contrast to the Cashel prelate's gloomy prediction to Kirby in 1863. ${ }^{130}$ The second point, however, appeared to contradict Cullen's own doubts about Irish emigrants retaining their faith as expressed in Liverpool twenty years before. What had changed? The words of an early pastoral letter give some indication. In 1853, partly in response to the Fr Mullen controversy, Cullen had stated that, 'Many of our poor people who emigrate, would be more punctual in performing 
their religious duties in distant countries, had they been accustomed to approach the sacraments in the churches at home. ${ }^{131}$ In the intervening years, Cullen had spearheaded a campaign to remedy this situation, so that, by the time of Lynch's warning, it was apparent that the emigrants who were leaving were in many cases the first products of the processes which came to be termed the devotional revolution. The anti-proselytism campaign that had promoted the parish mission, increased membership of sodalities, including the femaleoriented 'Children of Mary', ${ }^{132}$ and the expansion of Catholic schools, which, it was increasingly realised, were necessary to galvanise the faith of children who were likely future emigrants, ${ }^{133}$ were producing the desired orthodoxy. There was certainly no longer any notion of a 90 per cent rate of religious attrition among emigrants. Indeed, Cullen was given to complaints that churches in London with capacities of six or seven hundred were not big enough to accommodate the now much more devout Irish communities. ${ }^{134}$ There seemed to be less to worry about, both for emigrants and for the church they left behind. What was ultimately perceived, therefore, was a near-perfect arrangement, from which there would certainly still be casualties, but which would nonetheless see Ireland spread the Catholic religion in its most avowedly Roman form, while retaining and even strengthening the same doctrines at home.

Irish Catholic emigrants - at least, those who retained and helped to spread the faith - were a continuing source of pride to the church they left behind, reinforcing the popular self-conception of the Irish as 'the most intensely religious and practical Catholics in the world.. ${ }^{135}$ Moreover, as Emmet Larkin has argued, Famine and post-Famine migrants had an indirect practical impact on the devotional revolution, their absence meaning that increased vocations had an even greater proportional effect, and that those already more prosperous and devout classes who remained in Ireland were enabled to become even more so. ${ }^{136}$ It ought to be recognised, however, that the diaspora also exercised direct influences on the increasing orthodoxy of the Catholic Church in Ireland, which both fed on and fed into the notion of a 'spiritual empire' with Ireland at its centre. One as yet rather uncertain aspect of this appears to correlate with Irish evangelical experience. Transformations in religious practice can be diffuse and their causes difficult to pinpoint. Yet, if there were, as noted, clear transnational elements to the 1859 revival, in the sense that it took place (and was understood as taking place) within a wider evangelical 
world, something similar might be said of parallel Catholic developments. The trajectory of religious and devotional literature, which was likely useful in the spread of new and renewed Catholic devotional practices, helps illustrate the point. ${ }^{137}$

There had been a minor explosion in Catholic publishing in Ireland in the early decades of the century with Bishop James Doyle's efforts in promoting parish lending libraries and founding the Catholic Society for the Diffusion of Useful Knowledge throughout Ireland (better known as the Catholic Book Society) of particular note. However most of these initiatives seem to have been patchy and short-lived: evidently there was not yet a sufficiently large domestic market to sustain them long-term. Thus those commercial publishers who attempted to provide cheap volumes soon went out of business and, since not enough people could afford to buy more expensive books, the books remained expensive, limited in their range and few in number. ${ }^{138}$ For those who could afford to extend their collections, priests and bishops with lending libraries and reading rooms among them, London publishers, particularly Burns and Oates plugged some gaps. However, as Dublin reviewers later griped, it was 'English with an Irish accent' that was needed to bring Catholic teachings home to the mass of their readers. ${ }^{139}$

Consequently, as the book review columns of Irish Catholic journals, including the Irish Monthly and the Irish Ecclesiastical Record indicate, in the second half of the century an increasing number of important volumes originated in the 'colonies' of the 'spiritual empire'. In particular, several significant Irish-American Catholic publishers had been established in the 1840s and 1850s - among them P. O'Shea and P. J. Kenedy, both of New York, Sadlier of New York, Boston and Montreal and John Murphy of Baltimore. These companies produced books that smaller Irish imprints often could not hope to, whether lavishly bound and illustrated productions worthy of the episcopal library or, perhaps more significantly, affordable editions meant for mass consumption. ${ }^{140}$ Of especial importance in the latter respect were the American Paulists' Catholic Publication Society, which was founded in 1866 (and managed by an Irishman, Laurence Kehoe), and, to a lesser extent, its mirror, the English Catholic Truth Society, which was founded two years later by the Bishop of Salford and future Cardinal, Herbert Vaughan, and produced a variety of 'shilling publications', 'sixpenny publications' and 'penny publications. ${ }^{141}$ Both these organisations essentially aped Doyle's by then defunct book society 
in producing cheap volumes, but they were better placed to achieve critical mass, succeed commercially, and endure. That this all came some thirty years before Ireland's own lasting equivalent, the Catholic Truth Society was founded in 1899 is surely a key point.

The nature of the books coming from diaspora publishers and authors was also noteworthy, and it seems clear that they had the potential to feed into the devotional revolution. Religious histories, biographies, and fiction were most popular, but Irish Monthly reviewers were also impressed by, amongst others, 'the prettiest and holiest book which the English language has lately added to the literature of the Devotion to the Sacred Heart of Jesus' and 'the only journal in the English language which is specially devoted to the honour of the Blessed Virgin'. The latter, the reviewer noted, 'ought to be welcomed by us here at home where filial devotion to the Mother of God is, thanks be to God, one of the national hereditary instincts of our warm-hearted Celtic race. ${ }^{142}$ The same column, moreover, opened a review of the Philadelphia-based American Catholic Quarterly Review and the Melbourne-based St Patrick's College Gazette with the pithy observation that 'Living at the centre of civilisation - namely, Sackville-street, Dublin - we can afford to bestow a word of encouragement on deserving periodicals published at the antipodes or across the Atlantic. The reviewer was keen to point out that while the Australian journal was probably 'not meant for home circulation', readers in Ireland could very easily put their hands on the American publication since - an important point - 'the new postage to the US is the same as to the other side of the Liffey. ${ }^{143}$

Another notable genre given impetus by Irish publishers outside Ireland was yet more practical: a stream of instructional manuals on how to begin and run sodalities and confraternities, which were lay devotional organisations that were themselves significant in the diffusion of Catholic teachings and sometimes had significant lending libraries of their own. The spread of these societies, as Cormac Begadon has elaborated, was a notable feature of the devotional revolution. ${ }^{144}$ Meanwhile, works like Bernard O'Reilly's New York-published, The mirror of true womanhood, subtitled 'a book of instruction for women in the world' aimed to encourage an idealised version of Catholic family and devotional life. ${ }^{145}$ Irish clerics, too, found that the spiritual empire which they spoke of as the Irish church's creation had lessons in turn for them. The devotional revolution's new emphasis on the importance of ceremony and ritual meant that a strain of improving 
literature aimed at priests and even bishops emerged. ${ }^{146}$ These kinds of works had existed before, often in French or Latin, and they were occasionally produced in English (and only rarely Irish) by Dublin publishers including McGlashan and M. H. Gill, but the number and range of books afforded by a vast English-speaking Catholic 'empire' was likely significant in reinforcing Roman orthodoxy at home, among both clergy and laity. ${ }^{147}$

There is, however, a more obvious facet of the diasporic influence on the devotional revolution to be seen in church-building. Indeed, arguably the most obvious physical manifestation of Emmet Larkin's specifically mid-century delineation of his concept can be found in the stylistic contrast between many of the churches built before the Famine and those constructed after. As many of the memoirs, diaries, and letters of clergy used in this study attest, from the 1840 s on, emigrants were routinely called upon to contribute financially to the physical growth and sacred embellishment of those churches. This final section will therefore explore the extent and nature of this practice, and determine what it may mean for the 'spiritual empire'.

While a vast programme of church-building was begun in Ireland as soon as Catholic Emancipation was in sight, it was notably emboldened during the second half of the century. Precise figures for the postFamine period are not available, but Thomas Kennedy estimated that in the century following Emancipation, twenty four cathedrals and three thousand churches were built. ${ }^{148}$ Emmet Larkin, citing an 1864 study by Myles O'Reilly, claimed that a total of 1,805 churches had been erected since 1800, a figure with which Desmond Keenan agreed. ${ }^{149}$ As both Keenan and Nigel Yates have noted, most of the churches built before the Famine were of simple design, many simply larger versions of the ordinary Irish cottage, perhaps still with thatched roofs, clay floors or unplastered walls. In the better case scenario, they were 'huge and ungainly barns.' ${ }^{150}$ In a context where the consecrated chapel was becoming the centre of parish life and the scene of elaborate Ultramontane devotions, they hardly provided sufficiently holy settings, nor offered any reason to the waverer to attend. ${ }^{151}$ However, these simple chapels were in most cases rebuilt or remodelled in the second half of the century, generally conforming to a much more ornate, impressive and expensive style of architecture, and thereby symbolising the new orthodoxy, self-confidence and ebullience of Irish Catholicism. ${ }^{152}$

Continued emigration, in one respect, could have presented an obvious problem for such grand edifices. In 1875 J. Duncan Craig, 
a Church of Ireland vicar, somewhat hopefully recounted the tale of a colleague 'travelling in a carriage with a Roman Catholic bishop' who 'pointed out a very fine-looking cathedral, with the exclamation, "I am sorry to tell you we have now no more people than to half fill it"'. ${ }^{153}$ If that was the case at the time, it would not remain so; near-universal church attendance became a defining feature of Irish Catholicism by the last quarter of the nineteenth century, and churchbuilders everywhere strove to keep up with demand. In fact, emigration's impact on this physical expansion of the Irish church reflects an overlooked aspect of the existing discussion. If a defining trait of imperialism is the exploitation by the central power and its agents of the resources of the colonised territories, then in that sense at least, the Irish church truly did preside over a worldwide empire of its own. Donald Akenson's memorable description of Irish missionary clergy as 'the shock troops of the spiritual empire' might be said to have a counterpart; another class of priests could be termed its revenuecollecting officials, proving, despite what the likes of Canon Sheehan might have claimed, that God and Mammon sometimes had strikingly similar aims.

It should be noted from the outset that, once again, Presbyterians may well have got there first. Although the 1830s and 1840s saw intensive Presbyterian church-building in Belfast, largely funded by the city's wealthy laymen, it had long been the case that ministers of poorer, especially rural congregations often sought money for necessary building projects abroad. In 1843, for example, the newly installed incumbent of the infant Portrush congregation, Jonathan Simpson, made the first of three successful visits to the United States begging funds for 'a wee kirk. ${ }^{154}$ However, while money almost certainly still flowed back to Irish Presbyterian coffers from the diaspora, the practice of clerical fundraising tours seems to have been substantively discontinued with the advent of the General Assembly's Manse and Church building fund, aimed at helping 'weak', meaning poorer congregations in 1854. At a meeting to explain the parameters of the new scheme, James Morgan, himself an able church-builder, was particularly disapproving of foreign fundraising tours undertaken by pastors of such congregations. They forced long clerical absences on congregations that could ill bear them, did not always reap adequate rewards, and they were, he said, 'disrespectable to religion. ${ }^{155}$ Morgan saw an unbecoming indignity in such sojourns; as he apparently thought to himself on meeting a young Ulster minister fundraising in 
London, despite letters of character from home, 'everyone thinks you are a rogue and will treat you as such.'156

Notwithstanding a confirmed case of such roguery in 1842 - an Irishman in London impersonated a priest and fraudulently solicited donations for an invented Co. Wicklow chapel-building fund - there were evidently no such qualms in the Catholic Church. ${ }^{157}$ Indeed, just as the Presbyterian Church was resolving to abandon such fundraising methods, Catholic clergy had begun stepping up what had hitherto been a practice of last resort. ${ }^{158}$ This made increasing sense. Hapennya-week collections were a non-starter for the poorest parishes, lucrative charity sermons could only take place so often, and the sizeable donations which used to come from election candidates before the Famine seem to have been less common after. ${ }^{159}$ The problem, as ever, was particularly acute in the west of Ireland, and it was in that context that Bishops William Browne of Galway and William Higgins of Ardagh made trips to London in 1837 and America in 1842 respectively. ${ }^{160}$ As Higgins told Cullen in Rome, 'in order to complete the undertaking [the diocesan cathedral] I must not confine my exertions to a narrow sphere and having done what I can in Ireland, it will be necessary to appeal to the religious generosity of other countries. ${ }^{361}$ His example was to be followed more widely during the second half of the century.

The most well known such campaign was that for the putative Catholic University, begun with great fanfare at the Synod of Thurles in 1850. It was anticipated that 'our brethren, who are scattered not only through the sister kingdom and the British Colonies, but throughout the Continent of America' might be appealed to for 'the pecuniary means for the accomplishment of such an object.. ${ }^{162}$ This appeal took the form, initially, of an address by the Catholic University Committee to the Irish in America, which used much the same kind of impassioned language already witnessed:

Ireland turns with confidence to her children in the 'far west', and their numerous and prosperous descendants in the land of freedom. She has nurtured them in the true faith, which she has preserved for them and for herself by the ready sacrifice of earthly possessions, and often, when the occasion demanded, by the generous expenditure of her blood. In poverty she asks for assistance from the wealth and generosity of her friends and children. ${ }^{163}$

At least eight clergymen were subsequently sent in personal pursuit of this assistance, two to England - Francis M'Ginity, curate of Dundalk 
and Michael Hope, parish priest of Ballymore, Co. Meath - and six to North America. ${ }^{164}$ Two of the latter have already been encountered: Fr Mullen, whose indiscreet letter was discussed in Chapter Three, and Fr Peyton, whose emigrant guide featured in Chapter Two, jointly toured the interior dioceses of the United States from late 1851 to early $1853 .{ }^{165}$ A separate team, consisting of James Donnelly (also mentioned above), and Philip Devlin, a Donegal curate, had been sent in July 1851 and appears to have concentrated on the east coast. They were accompanied on their transatlantic voyage by Daniel Hearne, a well-known Manchester priest, who seems to have collected mainly in Canadian dioceses. ${ }^{166}$ Finally, at least one priest was also sent to the United States on behalf of the University in $1864 .{ }^{167}$ As head of the University committee, Cullen had written in advance of the collectors to the bishops of the dioceses they planned to visit, asking co-operation. ${ }^{168}$ By and large, the collectors got it. There seems to have been a genuine enthusiasm for their cause among some members of the North American hierarchy, particularly Dr Walsh of Halifax, who was an early and vocal champion of the university project. ${ }^{169}$ In addition, it certainly helped that, as Archbishop Hughes pointed out in a letter to the clergy of New York, the Pope himself had sanctioned the collection. ${ }^{170}$

This all attracted healthy sums of money - each collector's total ran into the thousands - for the never-built institution. ${ }^{171}$ Even before this major undertaking, however, there were already smaller-scale collections taking place on behalf of churches and cathedrals which did get erected. Batt O'Connor, parish priest of Milltown, Co. Kerry, was dispatched to Boston to collect for Killarney cathedral in $1847 ;{ }^{172}$ Michael Quinlivan, curate in Ennis, fundraised for a local church in England in $1850 ;{ }^{173}$ and Fr Mathew made a fundraising trip to the United States between 1849 and 1851. This last trip was remarkably, perhaps uniquely unsuccessful. Mathew's appeal as a temperance advocate was cross-denominational and his attempt to raise money not merely for that cause, but also for the completion of the Church of the Holy Trinity in Cork consequently backfired. Non-Catholics in his audiences were left with the uncomfortable impression that their contributions might end up benefiting the Catholic Church, and his efforts therefore raised little but Protestant hackles. ${ }^{174}$

That notable failure could not prevent an escalation in the number of foreign fundraising trips in the University collectors' train. The trend appears to have branched into three. Firstly, of the nineteen 
Catholic cathedrals built wholly or in part during the second half of the nineteenth century - cathedral-building generally being a process phased out over many years - at least sixteen were partially funded by a priest of the relevant diocese touring abroad in England, Scotland, North America or Australia. Of the other three, the builders of St Peter's cathedral in Belfast probably did not use this method of fundraising; the cathedral at Loughrea certainly received substantial donations from emigrants in America, but a priest was not sent abroad to fundraise therefore only the prelate of Ossory could boast that his episcopal seat in Kilkenny was built using subscriptions gathered wholly within his diocese. ${ }^{175}$ The planned Killaloe diocesan cathedral in Nenagh, which was never completed, was also begun with the proceeds of a priest's tour in America. ${ }^{176}$ Often, as with the University collection, more than one priest was fundraising abroad at a time, and in several cases collection tours were undertaken more than once, as each new phase of the building required it. ${ }^{177}$

Secondly, there appears to have been a tendency to fundraise abroad for the chapels attached to religious institutions. The Augustinians in both Galway and Dublin, the Franciscans in Clara, Co. Offaly and Clonmel, Co. Tipperary, the Jesuits in Galway, the Passionists of Mount Argus in Dublin, and the nuns of an unspecified St Joseph's convent school each went down this route, with the latter order employing the services of a Canon Magee to do the collecting. ${ }^{178}$ College chapels and seminary buildings could be similarly funded. ${ }^{179}$ It is likely that such activity exploited close connections with sister orders and alumni working among emigrant communities, ${ }^{180}$ and may have been considered a particular necessity for chapels which were normally the secondary church in a parish, and could not command a monopoly on local people's largesse.

Thirdly, and possibly most significantly, there seems to have been a pattern of priests in some very poor parishes seeking donations from emigrants, who often, but not exclusively, had a personal connection to the area. To a great extent, this remains a hidden process. There are a number of mentions of foreign collections for ordinary parish chapels in the Freeman's Journal, with references found particularly in speeches made at opening consecration Masses. ${ }^{181}$ These are surely a tiny sample of what was by and large a localised undertaking repeated across the country. Nevertheless, this limited evidence, coupled with occasional mentions in parish and diocesan histories, and in the Kirby collection, ${ }^{182}$ hint that it was thought common practice for priests 
to travel to raise otherwise unobtainable sums in emigrant destinations. As one church architect recalled, when he challenged a recent clerical client on the unsuitability of the cheaper altars he had chosen, the priest laughed, said he was not bound by architectural rules and might very well 'go to America some day, collect funds, and build a church to suit the altars.' ${ }^{183}$

The clerical tour abroad was not, however, the only means of extracting money from the diaspora for religious purposes. The amount of remittances sent home by ordinary Irish emigrants to their families was a source of amazement and curious pride among the great and good in Ireland. Charles Gavan Duffy MP spoke for many, when at a meeting to devise how to pay for the completion of St Catherine's Church in Meath Street, Dublin, he reminded those present, including Archbishop Cullen, that it was a known fact that more money was transmitted home by Irish emigrants in every part of the world than by emigrants of any other nation. ${ }^{184}$ Indeed, an otherwise puzzling note in one of the earliest issues of the Dublin Builder, the Irish architecture magazine, pointed out that 'serving girls and working people' in New York had recently been paid one and a half million dollars in dividends on the 'upwards of 30,000,000 dollars' they had deposited in savings banks. The clear implication was that a portion of this wealth might ultimately help pay for Irish architects' work. ${ }^{185}$ Priests and churchbuilding projects certainly commanded their share of the bounty. It is highly likely, if difficult to prove, that a significant proportion of cash remittances sent to family members, particularly elderly parents who did not intend to emigrate, found its way into church offerings. Meanwhile, direct emigrant contributions were certainly made to bazaars, or raffles, which became an increasingly popular method of raising money from the 1860 s. Tickets were frequently sent for sale to emigrant destinations, and there were sometimes reports of postponing the drawing of prizes until such time as tickets could be more widely distributed among the diaspora. ${ }^{186}$ There were also cases of emigrants remitting money or liturgical items directly to Irish clergy. ${ }^{187}$

Given these various revenue streams, putting a reliable figure on how much emigrant money was contributed to post-Famine Irish church-building is a tall order. That did not, however, prevent confident estimates being made in the early years of the new century by those answering criticism, of inappropriately high expenditure. ${ }^{188}$ Horace Plunkett's ill-judged critique of the 'extravagance' of so many 
'gaudy edifices' built 'at the expense of poor communities', which, he asserted, 'shocks the economic sense', prompted Monsignor Michael O'Riordan's claim that somewhere between a fifth and a quarter of all money used for the purpose came not from the Irish at home but from the Irish abroad. ${ }^{189}$ The art critic Robert Elliott went further, suggesting that, factoring in all forms of fundraising, half the money had been collected abroad, while the barrister Michael McDonnell asserted that Catholic churches had 'in large measure' been built by emigrant contributions. ${ }^{190}$ Patrick Moran agreed with these estimates, reporting that Cardinal Michael Logue had told him that it is from the United States, from friends of Ireland in the home countries, and in the colonies, that the greater part of the funds have been derived to erect such noble monuments of religion. ${ }^{3}$ The credibility of all of these estimates, each, perhaps, with its own agenda, is questionable. However, even in the absence of an exhaustive examination of parish and diocesan accounts, and without challenging the notion that a remarkable, mass, micro-donation culture largely built the ecclesiastical infrastructure of Catholic Ireland, ${ }^{192}$ there can be little doubt that the diaspora's direct and indirect contributions to churchbuilding funds were highly significant, and in very many individual cases, vital. ${ }^{193}$

While that conclusion can certainly be qualified by evidence that, in the case of some larger projects, the contribution from foreign fundraising trips could be tiny, relative to the vast overall building cost, a key point to be made here is that there was nonetheless an habitual, almost instinctive resort to fundraising among the wider 'Irish race. This trend, despite the logistical difficulties of fundraising abroad, and its sometimes relatively meagre returns, indicates that the idea of a specifically Irish spiritual empire was keenly felt among Irish clergy and that it embraced lay emigrants every bit as much as the 'shock troops' who ministered to them. ${ }^{194}$ The Irish church - as distinct from the missionaries it sent out - did not sever its ties with emigrants when they became immigrants. The oft-repeated description of them as 'the children of St Patrick' was no mere rhetorical flourish, but rather reflected a widespread belief that, just as the parent church had a duty of pastoral care towards emigrants, a kind of familial allegiance was owed by them to their home church. This created its own tensions. The legendary generosity of the Irish, and especially Irish-American servant girls, may have helped build many churches in the United States, but as Joseph Dixon, Archbishop of Armagh, 
emphasised in 1863, the 'daughters of Erin' were also expected to 'rival the zeal of the women of Israel' when it came to erecting churches in Ireland. ${ }^{195}$ This could rile foreign churchmen, including those of Irish origin, who saw their own collections threatened by interlopers. ${ }^{196}$ Many bishops therefore refused to grant the necessary permission for Irish priests to collect in their dioceses, and consequently Tobias Kirby was sometimes asked to procure a powerful Papal recommendation for such missions. ${ }^{197}$ Even where bishops did allow Irish collectors, there could be obstructionism from discommoded parish clergy, as the entertainingly frank tour diary of the Passionist Father Pius Devine attests. ${ }^{198}$

Despite these worries, it seems likely that what all of this meant for the more devout emigrants was simply a double taxation on their resources. That may have been tolerable for the likes of the old woman who reportedly sent $\$ 10,000$ for the upkeep of churches to the Bishop of Limerick, ${ }^{199}$ but must have been a considerable burden for the poor domestic servants and labourers who were being asked to pay towards chapels in which they would never even worship, and who were, as Michael Buckley noted, usually ready to give to any Irish priest who begged from them, often donating well beyond their apparent means, and brooking no objections on the priest's part. ${ }^{200}$ Consciously or not, collectors were adept at exploiting emigrants' sense of longing for 'the ould sod' for their own ends, just as 'the priest too poor to travel' was adept at using familial expectations for his purposes. There are clear hints in some emigrant correspondence that Irish relatives, who wrung vital personal remittances from their departed kin, could also pressure them into donating to local church-building funds in order to burnish the family's 'respectable' reputation at home. Nothing perhaps, symbolised the achievement of financial success, the retention of what was deemed a proper sense of duty to those left behind, and the maintenance of a devout Catholic faith quite as much as a donation toward the home chapel, and its announcement from the pulpit. ${ }^{201}$ Certainly, there were some who declined to donate to Irish churches. Yet while Devine's diary contains a number of indecorous references to 'stingy' people who 'don't give well', they serve merely to highlight the towering sense of entitlement that Irish priests harboured toward the disposable incomes of Irish emigrants and even their descendants, mirroring the attitude of Irish families, who, in Grace Neville's stinging judgement, seemed to believe they had 'an unspoken right to the hard-earned dollars of those who left'. ${ }^{202}$ It can be difficult not to 
agree with Fr John Brummer of Cincinnati, who observed some Irish going 'to ruin' in the United States 'on account of not being cared for but to collect their hard earned dollars'. ${ }^{203}$

Nonetheless, it seems clear that, for all its sometimes overblown rhetoric, the widely held idea of a 'spiritual empire' emerging from a 'divine mission' accorded to Irish emigrants had important repercussions. Beyond the expansion of Irish ecclesiastical power and the manufacture of a useful sense of pride among emigrants and the Irish at home alike, the Irish Catholic Church managed to use the narrative in a way which boosted its own prestige and capacity at home. This does not suggest a desire to see emigration from Ireland perpetuated - there had to be, after all, worshippers to fill the churches as well as to contribute towards their erection - but it does constitute an impressive ability on the part of church spokesmen, not only to rationalise an exodus over which the hierarchy and the clergy realised they could exercise very little control, but also to make the best of the situation in which they found themselves. Indeed, while Paul Cullen felt able to condemn the Fenians in an 1866 pastoral letter for having 'collected millions of dollars' in the United States with which they had hired 'noble palaces, ${ }^{204}$ he, and the church that he led, were ultimately open to a similar charge.

\section{Notes}

1 James J. Walsh, The World's Debt to the Irish (Boston, 1926); J. J. O'Kelly, Ireland's Spiritual Empire Saint Patrick as a World Figure (Dublin, 1952); Jeremiah Newman, 'Emigration and the faith: the principles' in Christus Rex, x:4 (1956), 315-34; Delaney, 'Churches and Irish emigration'; D. Vincent Twomey, The End of Irish Catholicism? (Dublin, 2003), pp. 25-6; Enda Delaney, The Irish in Post-War Britain (Oxford, 2007), pp. 186-7. Contemporary criticism of the notion - as in Joseph Cunnane, 'The layman' in The Furrow, viii:2 (Feb. 1957), 105 - serves also to show how widespread it was. Patrick Bishop, The Irish Empire (London, 1999); The Irish Empire [TV series], BBC (2000).

2 This title has also been used with a more scholarly question mark for an edited volume dealing with Ireland and empire. Keith Jeffery (ed.), An Irish Empire?: Aspects of Ireland and the British Empire (Manchester, 1996); see also Christine Kinealy, 'At home with the empire: the example of Ireland' in Catherine Hall and Sonya O. Rose (eds), At Home with the Empire: Metropolitan Culture and the Imperial World (Cambridge, 2006), p. 96. 
3 The following mention the idea: Fitzpatrick, 'Ireland and the empire', pp. 519-20; Fitzpatrick, Irish Emigration, p. 17; Kevin Kenny, 'The Irish in the empire' in Kevin Kenny (ed.), Ireland and the British Empire (Oxford, 2004), pp. 113-14; O’Farrell, Irish in Australia, p. 240; Patrick Corish, The Irish Catholic Experience: A Historical Survey (Dublin, 1985), p. 215; Oliver MacDonagh (ed.), Emigration in the Victorian Age: Debates on the Issue from 19th Century Critical Journals (Farnborough, 1973), [no pagination]; Lawrence J. McCaffrey, 'Irish textures in American Catholicism' in The Catholic Historical Review, lxxviii:1 (Jan. 1992), 1; Lawrence J. McCaffrey, The Irish Catholic Diaspora in America (Washington, 1997), p. 98; Andy Bielenberg, 'Irish emigration to the British empire, 1700-1914' in Andy Bielenberg (ed.), The Irish Diaspora (London, 2000), p. 228.

4 Miller, Emigrants and Exiles, pp. 455-6; Hilary M. Carey, 'Religion and society' in Deryck Marshall Schreuder and Stuart Ward (eds), Australia's Empire (Oxford, 2008), p. 195; Mary E. Daly, The New Failure: Population Decline and Independent Ireland, 1922-1973 (London, 2006), p. 261; Schrier, Ireland and the American Emigration, p. 65.

5 Kerby A. Miller, 'Ideology and identity in post-Famine Ireland' in Studies: An Irish Quarterly, lxxv:300 (Winter, 1986), 520-1; Miller, Emigrants and Exiles, p. 302, p. 458-9, pp. 532-3.

6 Rafferty, 'The Catholic Church and the British Empire 1800-1921', p. 6; Donald Harman Akenson, Half the World from Home Perspectives on the Irish in New Zealand 1860-1950 (Wellington, 1990), pp. 163-4. Colin Barr, whose concentration is on Irish domination of the upper echelons of the global Catholic Church, appears to posit a weak connection between the diffusion of Irish emigrants and the appointment of Irishmen to foreign dioceses. Many such appointments, he explains, were not 'the necessary consequence of large-scale Irish emigration' but 'the result of a carefully-planned campaign [by Cullen] to install Irish bishops in the several national hierarchies. That argument, backed by evidence that in certain instances, Irish bishops preceded any significant Irish population, is convincing. However, as Barr comes close to admitting, it would have been inconceivable that such a campaign could have succeeded in the absence of mass Irish Catholic migration. Colin Barr, "Imperium in Imperio": Irish episcopal imperialism in the nineteenth century' in English Historical Review, cxxiii:502 (June, 2008), 611-13.

7 Declan Kiberd sees the idea starting in the 1860s, while Patrick O'Farrell labels it an even later phenomenon, beginning with Canon Sheehan's 1882 I.E.R. evocation. P. A. Sheehan, 'The effect of emigration on the Irish church' in I.E.R., $3^{\text {rd }}$ series, iii (Oct. 1882), 603-14; Declan Kiberd, Inventing Ireland. The Literature of the Modern Nation (London, 1996), p. 276; O'Farrell, Irish in Australia, p. 240; Patrick O'Farrell, Ireland's English Question Anglo-Irish Relations 1534-1970 (London, 1971), pp. 235-40. 
David Doyle, reviewing scholarship on the diaspora, referred to 'the 'Ireland's Spiritual Empire' thesis of the 1950s'; David Noel Doyle, 'Small differences?: the study of the Irish in the United States and Britain' in I.H.S., xxix:113 (May, 1994), 118; see also Conor Cruise O'Brien, States of Ireland (London, 1972), p. 53; Desmond Fennell, The State of the Nation: Ireland since the Sixties (Dublin, 1983), p. 72.

8 Gilley, 'Catholic Church and the diaspora', pp. 188-207; Sheridan Gilley, 'Catholicism, Ireland, and the Irish diaspora' in Sheridan Gilley and Brian Stanley (eds), World Christianities c. 1815-1914 (Cambridge, 2006), pp. 250-9; Sheridan Gilley, 'Catholicism in Ireland' in Hugh McLeod and Werner Ustorf (eds), The Decline of Christendom in Western Europe, 1750-2000 (Cambridge, 2003), pp. 99-112. See also Irene Whelan, 'Religious rivalry and the making of Irish-American identity' in J. J. Lee and Marion R. Casey (eds), Making the Irish American: History and Heritage of the Irish in the United States (New York, 2006), pp. 280-1.

9 Kiberd, Inventing Ireland, p. 276.

10 Carl Reeve and Ann Barton Reeve, James Connolly and the United States: The Road to the 1916 Irish Rebellion (Atlantic Highlands, c. 1978) p. 173; F.J., 28 Apr. 1864.

11 John Francis Maguire, The Irish in America (London, 1868); Nicholas Flood Davin, The Irishman in Canada (London, 1877); James Francis Hogan, The Irish in Australia (London, 1888); F. A. Fahy and D. J. O'Donoghue, Ireland in London (Dublin, 1889); P. S. Cleary, Australia's Debt to Irish Nation-Builders (Sydney, 1933). A throwback to this kind of literature - from a rather different perspective - can be found in Ian R. K. Paisley, America's Debt to Ulster (Belfast, 1976).

12 For Cullen's use of the phrase, see Patrick Francis Moran, The Pastoral Letters and other Writings of Cardinal Cullen, Archbishop of Dublin (3 vols, Dublin, 1882), i, 624; Archbishop Lynch of Toronto also described Ireland as such in a speech reported by the F.J., 14 Aug. 1879.

13 Evidence cited in John Francis Maguire, Father Mathew: A Biography (London, 1865), p. 304; it correlates with Mathew's belief in a providential emigration as previously expressed before Parliament. Report on colonisation, p. 253, H.L. 1847 (737-II), vi, 282.

14 Orestes A. Brownson, 'Father Thébaud's Irish race' in Orestes A. Brownson and Henry Francis Brownson (eds), The Works of Orestes A. Brownson (1884), p. 560.

15 Burke, Lectures, p. 212.

16 Kevin Collins, Catholic Churchmen and the Celtic Revival in Ireland, 1848-1916 (Dublin, 2002), pp. 60-79; Patrick F. Moran, Essays on the Origin, Doctrines and Discipline of the Early Irish Church (Dublin, 1864); Patrick F. Moran, Irish Saints in Great Britain (Dublin, 1879); Martin Haverty, The History of Ireland, Ancient and Modern (Dublin, 1867), pp. 
91-106; Louis Gougaud, Gaelic Pioneers of Christianity: The Work and Influences of Irish Monks and Saints in Continental Europe (Dublin, 1923). The pages of Daniel O'Connell's Dublin Review also routinely referred to the work of the monks. See for example Anon., 'Notice of new books' in Dublin Review, iii:5 (July, 1837), 270.

17 This description came from the Rector of the English College in Bruges, Monsignor de Haerne. F.J., 13 Sept. 1878.

18 J. Cardinal Gibbons, 'Irish immigration to the United States' in I.E.R., 4th series, i (Feb. 1897), 109.

19 F.J., 30 May 1850.

20 Michael Phelan, 'The supernatural destiny of the Irish race' in The Austral Light, new series, x:6 (June, 1909), 405; Catholic Telegraph, 15 Mar., 1862.

21 Frederick J. Zwierlein, The Life and Letters of Bishop McQuaid (3 vols, New York, 1925), i, 116.

22 Augustus Thébaud, The Irish Race in the Past and the Present (New York, 1873), pp. 439-40.

23 Maureen Wall, 'The decline of the Irish language' in Brian Ó Cuív (ed.), A View of the Irish Language (Dublin, 1969), p. 87; Diarmait MacGiolla Chríost, The Irish Language from Goídel to Globalisation (London, 2004), p. 101; On Irish-speaking among the priesthood, see Nicholas M. Wolf, 'The Irish-speaking clergy in the nineteenth century: education, trends, and timing' in New Hibernia Review/Iris Eireannach Nua, xii:4 (Winter, 2008), 62-83.

24 W.T., 9 Dec. 1854.

25 Annals of All Hallows (1862), 31.

26 Phelan, 'The supernatural destiny of the Irish race', 407.

27 John Henry Newman, The Office and Work of Universities (London, 1859), p. 224.

28 Patrick O'Farrell, Ireland's English Question, pp. 235-7.

29 Anon., 'The patriotism of Irish Catholicity' in Irish Monthly, xv (1887), 669-70.

30 P. S. Dineen, 'The world-wide empire of the Irish race: A plea for its organisation' in Journal of the Ivernian Society ii:6 (Jan. 1910), 79-94. This could be taken to refer only to preaching by Irish priests in the new world. However, the former Bishop of Pittsburgh, Michael O'Connor, related an anecdote of a mistress reading letters to her illiterate servant girl from a priest in Ireland and being convinced by them into converting. Moreover, as Oscar Handlin observed, the servant girl or other immigrant who converted their employer whether through pious example or active proselytism was lauded in immigrant literature. Michael O'Connor, The Sogarth Aroon, or, the Irish Priest: A Lecture (Baltimore, 1869), p. 21; Oscar Handlin, Boston's Immigrants, 1790-1880: A Study in Acculturation (Cambridge, 1959), pp. 185-6. 
31 The Tablet, 2 Oct. 1852; F.., 20 Sept. 1852.

32 F.J., 16 Jan. 1864.

$33 \mathrm{M}$ [ichael] O'Connor, 'The destiny of the Irish race' in I.E.R., i (Nov. 1864), 72.

34 F.J., 23 Oct. 1863.

35 O'Connor, 'The destiny of the Irish race', 84.

36 Thébaud, Irish Race, p. 81. The Egyptian reference, ostensibly a biblical allusion, may well relate to the Milesian myth of Irish origin. See Lesa Ní Mhunghaile, Anglo-Irish antiquarianism and the transformation of Irish identity, 1750-1800' in David A. Valone and Jill Marie Bradbury AngloIrish Identities, 1571-1845 (Lewisberg, 2008), p. 184.

37 Dineen, 'The world-wide empire of the Irish race', p. 83.

38 Canon [P. A.] Sheehan, Early Essays and Lectures (London, 1906), pp. 269-70.

39 Sheehan, 'The effect of emigration on the Irish church', 611.

40 Mary Donoghue McCain, 'Father Thomas N. Burke, O.P.: The sacredness and eloquence of the word' (PhD Thesis, University of Chicago, 2012), p. 213.

41 W.T., 26 Mar. 1853.

42 D. W. Cahill, Argumentative Letter from the Rev. Dr Cahill to the Rt. Hon. Earl of Derby on the General Character of English Statesmen in Endeavouring to Uproot the Catholic Church - and, as it were, to send the Protestant Bible to teach all Nations?, (Dublin, 1852), pp. 11-12.

43 Kerby A. Miller, "Revenge for Skibbereen': Irish emigration and the meaning of the Great Famine' in Miller, Ireland and Irish America, p. 66.

44 Dr [Paul] Cullen, Pastoral Letter to the Catholic Clergy and Laity of the Diocese of Dublin, on the Festival of St Patrick (Dublin, 1853), p. 28.

45 For comparison between nineteenth-century Protestant missions and later Catholic missions, see Fiona Bateman, 'Ireland's spiritual empire: territory and landscape in Irish Catholic missionary discourse' in Hilary M. Carey (ed.), Empires of Religion (London, 2008), pp. 267-87.

46 Stewart J. Brown, Providence and Empire: Religion, Politics and Society in the United Kingdom, 1815-1914 (Harlow, 2008), p. 3.

47 Stanley, The Bible and the Flag, passim; John Barker, 'Where the missionary frontier ran ahead of Empire' in Norman Etherington (ed.), The Oxford History of the British Empire, Companion series: Missions and Empire (Oxford, 2005), pp. 86-106; Porter, Religion Versus Empire?, passim; John H. Darch, Missionary Imperialists? Missionaries, Government and the Growth of the British Empire in the Tropics, 1860-1885 (Milton Keynes, 2009), pp. 237-46.

48 Brown, Providence and Empire, pp. 195-6; Strong, Anglicanism and the British Empire, pp. 280-1, pp. 285-9; Andrew Porter, 'Religion, missionary enthusiasm, and empire' in Porter, Oxford History of the British Empire iii, p. 238. 
49 Fitzpatrick, 'Ireland and the empire', p. 520.

50 Methodists seemed more inclined to single their emigrants out for glorification, in the manner of Irish Catholic commentators, although they too did so within a clearly cooperative, British framework. See Minutes of the Methodist Conference in Ireland (June, 1853), pp. 32-3; David Hempton, "For God and Ulster': Evangelical Protestantism and the Home Rule crisis of 1886 in Keith Robbins (ed.) Protestant Evangelicalism: Britain, Ireland, Germany and America, c. 1750-c.1950 Essays in honour of W.K. Ward (Oxford, 1990), p. 237; David Hempton, Methodism. Empire of the Spirit (London, 2005), pp. 30-1.

51 Buckley, Saint Patrick, apostle of Ireland, pp. 11-14; A work by the professor of ecclesiastical history at Assembly's College, Belfast declined even to make the connection between past missions and present missions explicitly. James Heron, The Celtic Church in Ireland: The Story of Ireland and Irish Christianity from before the Time of St Patrick to the Reformation (London, 1898).

52 Hempton and Hill, Evangelical Protestantism, pp. 182; More recent work on the Anglican church and the settler empire notes that Anti-Catholicism was the most striking Irish contribution to colonial Anglicanism. Hardwick, An Anglican British World, ch. 5.

53 Cecil J. Houston and William J. Smyth, The Sash Canada Wore: A Historical Geography of the Orange Order in Canada (Toronto, 1980), p. 144; Donald M. MacRaild, 'The associationalism of the Orange diaspora' in David A. Wilson (ed.) The Orange Order in Canada (Dublin, 2007), p. 29.

54 Frederick Douglas How, William Conyngham Plunket Fourth Baron Plunket and Sixty-first Archbishop of Dublin: A Memoir (London, 1900), p. 191.

55 The Church of Ireland in the Present Crisis: Report of the Special Meeting of the General Synod, holden at Dublin, March 23, 1886 (Dublin, 1886), pp. $14-15 ; 37$.

56 John Brown, Jacob, pp. 8-12.

57 James Loughlin, Gladstone, Home Rule and the Irish Question 1882-93 (Dublin, 1986), pp. 295-6; Hempton, 'For God and Ulster', p. 245; see also Alan Megahey, "God will defend the right": the Protestant Churches and opposition to Home Rule' in D. G. Boyce and Alan O'Day (eds), Defenders of the Union: A Survey of British and Irish Unionism since 1801 (London 2001), pp. 159-75; Pamela Clayton, Enemies and Passing Friends. Settler Ideologies in Twentieth-Century Ulster (London, 1996), pp. 113-16; see also Andrew R. Scholes, The Church of Ireland and the Third Home Rule Bill (Dublin, 2010).

58 The Church of Ireland in the Present Crisis, pp. 14-15; 36-7; Brown, Providence and Empire, pp. 321-4.

59 John Flanagan, Ireland: Her Past Glories and Trials, and Probable Future (Dublin, 1882), pp. 165-6. 
60 M.H. (1862), 4; Evangelical Witness and Presbyterian Review, 1 Aug. 1866.

61 Hempton and Hill, Evangelical Protestantism, p. 182.

62 Gilley, 'Catholic Church and the diaspora', 206-7.

63 F.J., 2 Jan. 1852.

64 I.C.R.A., Kirby papers, KIR/1847/545, letter from M. P. Riordan, Waterford to Kirby, 30 Mar. 1847.

65 Ibid., KIR/1863/170, letter from George Commins to Kirby, 19 June 1863.

66 Ibid., KIR/1864/82, letter from T. W. Croke to Kirby, 8 Apr. 1864.

67 F.J., 19 Sept. 1839; Anon 'Transatlantic travelling' in Dublin Review, vii (Nov. 1839), 327.

68 F.J., 30 Jan. 1841.

69 John MacHale, 'Ireland' in Annals of the Propagation of the Faith, iii:13 (Jan. 1840), 74.

70 W. J. O'Neill Daunt, Personal Recollections of the Late Daniel O'Connell, MP (2 vols, London, 1848), i, p. 293.

71 Anon, 'Ancient Irish Missions on the continent' in Duffy's Irish Catholic Magazine: A Monthly Review, i (Apr. 1847), 67-9; Joseph Farrell, Sermons (Dublin, 1895), pp. 17-18., p. 245.

72 Perraud, Ireland, pp. 241-2.

73 Sheehan, 'The effect of emigration on the Irish church', 612-13.

74 Morgan, Thoughts, p. 14; Gray, 'National humiliation', 203-9.

75 The Tablet, 29 Aug. 1846. There are obvious sympathies here with John Mitchel's infamous dictum that 'The Almighty, indeed, sent the potato blight but the English created the Famine, which he elsewhere describes as 'the British government fulfil[ing] the designs and administer[ing] the dispensation of Providence.' John Mitchel, The Last Conquest of Ireland (Perhaps) (Dublin, 1861), p. 219; John Mitchel, Jail Journal; Or Five Years in British Prisons (New York, 1854), p. 22. An earlier MacHale pastoral had suggested that 'the people are on the verge of famine, in punishment of the sins of their infidelity'. The Tablet, 20 Feb. 1846.

76 Peadar MacSuibhne, Paul Cullen and his Contemporaries (5 vols, Naas, 1965), iii, pp. 353-4.

77 Anon, 'Emigration considered with reference to its influence on the spread of Catholicity' in The Rambler: A Catholic Journal and Review of Home and Foreign Literature, Politics, Science, Music and the Fine Arts, xi:66 (June 1853), 466; F.J., 30 May 1850, 29 Mar. 1850.

78 Hugh Quigley, The Cross and the Shamrock, or, How to Defend the Faith: An Irish-American Catholic Tale of Real Life, Descriptive of the Temptations, Sufferings, Trials, and Triumphs of the Children of St Patrick in the Great Republic of Washington (Boston, 1853), p. 124; Charles Fanning, The Irish Voice in America: 250 years of Irish-American Fiction (Lexington, 1999), p. 142. 
79 P. A. Sheehan, The Graves at Kilmorna (Dublin, 1915), p. 338; Fitzpatrick, Oceans of Consolation, p. 553.

80 John O'Leary, Recollections of Fenians and Fenianism (2 vols, London, 1896), ii, p. 31.

81 Irish People, 21 May 1864.

82 Rafferty, The Church, the State, and the Fenian Threat, p. 64; Irish Canadian, 18 Mar. 1863, Canadian Freeman, 19 Mar., 1863, The Globe, 18 Mar. 1863; as cited in Michael Cottrell, 'St Patrick's day parades in nineteenth-century Toronto: A study of immigrant adjustment and elite control' in Francesca Iacovetta, Paula Draper and Robert Ventresca (eds), A Nation of Immigrants: Women, Workers, and Communities in Canadian History, 1840s-1960s (Toronto, 1998), p. 36; Irish Canadian 22 Mar. 1871 as cited in Mark G. McGowan, 'Roman Catholics (Anglophone and Allophone)' in Paul Bramadat and David Seljak (eds), Christianity and Ethnicity in Canada (Toronto, 2008), p. 54; F.J., 22 May 1871, 3 Dec. 1873, 14 Aug. 1878.

83 See G. J. Stortz, 'Archbishop Lynch and New Ireland: An Unfulfilled Dream for Canada's Northwest' in Catholic Historical Review, lxviii:4 (Oct. 1982), 612-24 for Lynch's later attempt to put his views into practice. See Spalding, Religious Mission for similar themes.

84 Anon., 'Romanism in America' in Evangelical Witness and Presbyterian Review, v (Aug. 1866), 211-14; [Croskery], 'The Irish abroad', 520-2; J. Duncan Craig, Real Pictures of Clerical Life in Ireland (London, 1875), pp. 290-1.

85 F.J., 5 Sept. 1864.

86 I.C.R.A., Kirby papers, KIR/1865/172, letter from J. O'Leary to Kirby, 28 July, 1865. Similar rejection of the idea came in the wake of the 1880s peak of emigration. John Riordan, chaplain at New York's Mission of Our Lady of the Rosary sounded a note of caution in 1884, while an Irish-American doctor wrote Archbishop Croke in 1887: 'Tis said they [Irish emigrants] are the missionaries of the world being so destined by God. No, no. If those who say so or think so could but see what daily falls to my lot to witness, they should quickly change these ideas. If God so destined the Irish people then he predestined them to carry and give the faith to others and to lose it themselves, for this is just what is daily going on around me here. The Church is rapidly dying out'; F.J., 15 Aug. 1884; C.D.A., Croke papers, 1887/21: microfilm, N.L.I., p. 6010-13, letter from P. O'Connell, Chicago to Croke, 10 June 1887.

87 F.J., 25 July 1862.

88 F.J., 6 Mar. 1865.

89 James S. Donnelly Jr, 'The Irish Agricultural Depression of 1859-64' in Irish Economic and Social History, iii (1976), 33-54. 
90 See Larkin, Consolidation, pp. 101-5, pp. 282-7. It is worth noting that the obvious physical dangers posed to emigrants by the American Civil War appear to have troubled Irish bishops less than the moral and spiritual dangers of which Lynch warned. See D.D.A., Cullen papers, outgoing letter book 121/5, Cullen to Moran, 20 May 1864; D.D.A., Cullen papers, outgoing letter book 121/4, Cullen to Charles Langdon, 1 July 1865.

91 Larkin, Consolidation, p. 287.

92 Ibid., p. 276; Norman, Catholic Church, p. 387.

93 Ibid., p. 148.

94 I.C.R.A., Kirby papers, KIR/1863/101, letter from Leahy to Kirby, 27 Mar. 1863.

95 Catholic Telegraph, 20 June 1863.

96 Norman, Catholic Church, p. 409.

97 While the average of c. 70,000 departures per year did more than halve between 1875 and 1879 - until another harvest crisis restored it to the former level - it is highly doubtful that the Land Act was responsible. Guinnane, Vanishing Irish, pp. 238-9.

98 C.D.A., Leahy papers, 1872/13: microfilm, N.L.I., p. 6010-13, Sermon preached at the Consecration of the Right Rev. Dr Moran, Coadjutor Bishop of Ossory, in the Metropolitan Church of Dublin on the 5th of March, 1872 by the most Rev. Dr Leahy, 1872.

99 O'Leary, Fenians \& Fenianism, ii, p. 36.

100 James O'Leary also argued strongly to Kirby during 1865 that the people felt abandoned by their bishops because of their condemnation of the Fenians, and that emigration was partly a result of that sense of abandonment. I.C.R.A., Kirby papers, KIR/1865/172, letter from James O'Leary, St Colman's, Fermoy to Kirby, 28 July, 1865 and KIR/1865/218, letter from same to same, 5 Oct. 1865.

101 John MacHale, A Refutation of the Earl of Shrewsbury's Calumnies against the Catholic Clergy and Bishops of Ireland (Dublin, 1848), p. 22; F.J., 24 Feb. 1847.

102 F.J., 9 Mar. 1869.

103 I.C.R.A., Kirby papers, KIR/1863/13, letter from Gillooly to Kirby, 10 Jan. 1863; F.J., 11 June 1866.

104 In fact it is impossible to escape the suspicion that Durcan was an otherwise unremarkable figure. Local lore recalls him as a church-building bishop - 'Patrick of the churches' - but in the mid-nineteenth century hierarchy that was a trait barely more distinctive than the wearing of a mitre. Liam Swords' comment that his era 'coincided with the period of church-building' is instructive. As to his politics, by the 1860s, Durcan was aged and ailing and unable - rather than unwilling - to curb widespread clerical sympathy with Fenianism in his diocese. Emmet Larkin, The 
Making of the Roman Catholic Church in Ireland, 1850-1860 (Chapel Hill, 1980), pp. 153-7; p. 334; Terence O'Rorke, History, Antiquities and Present State of the Parishes of Ballysadare and Kilvarnet, in the County of Sligo (Dublin, 1878), pp. 498-9; Liam Swords, A Dominant Church: The Diocese of Achonry, 1818-1960 (Blackrock, 2003), pp. 31-2, 355-77.

105 Bernard O'Reilly, John MacHale, Archbishop of Tuam. His Life, Times and Correspondence (2 vols, New York, 1890), ii, p. 317; F.., 17 Aug. 1867.

106 John MacHale, The Splendid Oration delivered by the Most Reverend Dr MacHale, Abp of Tuam, at the Opening of the Second Session of the National Synod of Ireland, on Thursday, August 29th, 1850 (Dublin, 1850), p. 12; F.J., 8 June 1854.

107 Colin Barr, Paul Cullen, John Henry Newman, and the Catholic University of Ireland, 1845-1865 (Leominster, 2003), p. 154.

108 Judge they have. See E. D. Steele, 'Cardinal Cullen and Irish nationality' in I.H.S., xix:75 (Mar. 1975), 239-60; D. George Boyce, Nationalism in Ireland (London, 1995), p. 180; Kerr, Nation of Beggars, p. 325; Norman, Catholic Church, p. 10, p. 426; Desmond Bowen, Paul Cardinal Cullen, pp. 272-81. Ciaran O'Carroll, Paul Cardinal Cullen: Portrait of a Practical Nationalist (Dublin, 2008); Matthew Kelly, 'Providence, revolution and the conditional defence of the union: Paul Cullen and the Fenians' in Keogh and McDonnell, Cardinal Paul Cullen and his World, pp. 308-28.

109 Paul Bew, Ireland: The Politics of Enmity 1789-2006 (Oxford, 2007), p. 257.

110 See, particularly, pastorals printed in the W.T., 2 May 1863; F.., 30 Apr. 1866, 27 Jan. 1868.

111 Larkin, Consolidation, p. 282; If that was indeed the case, it might be explained by the fact that, as Cullen noted to Kirby, 'The emigration from Munster \& from Connaught is very great - scarcely anyone is going away from this diocese. This country was cleared one hundred years ago'. I.C.R.A., Kirby papers, KIR/1863/322, letter from Cullen to Kirby, 11 December, 1863.

112 Ibid., KIR/1864/86, letter from Cullen to Kirby, 15 Apr. 1864.

113 D.D.A., Cullen papers, outgoing letter book 121/5, letter from Cullen to Moran, 20 May 1864.

114 I.C.R.A., Kirby papers, KIR/NC/1/1860/34, letter from Cullen to Kirby, 27 Apr. 1860.

115 Ibid., KIR/1864/178, letter from Cullen to Kirby, 29 Sept. 1864; Ibid., KIR/1868/11, letter from Cullen to Kirby, 7 Jan. 1868.

116 David Steele, 'Daniel O'Connell, Cardinal Cullen and expatriate nationalism' in Donal McCartney (ed.), The World of Daniel O'Connell (Dublin, 1980), pp. 88-99; Donal McCartney, The Dawning of Democracy: Ireland 1800-1870 (Dublin, 1987), p. 163. 
117 Guilday, Life of John England, ii, p. 357.

118 I.C.R.A., Kirby papers, KIR/1842/98, letter from Cullen to Kirby, 25 June, 1842.

119 To the many examples cited earlier might be added James Cardinal Gibbons, 'St Patrick. The apostolic mission of the Irish race' in Idem, A Retrospect of Fifty Years (2 vols, Baltimore, 1916), ii, pp. 170-89 [Sermon originally preached in Baltimore, 17 March 1871]; also worth noting is an anniversary celebration of St Columba by Dr Shahan of the Catholic University of America as reported in the New York Times, 7 June 1897.

120 To an extent this tied in with continental European religious orders' attitude to Ireland; French orders, in particular, set up dozens of houses in (fulfilled) expectation of a flood of Irish postulants. Rafferty, 'The Catholic Church and the British Empire 1800-1921', p. 300; Ciaran O'Neill, 'Colonised twice?: Rethinking the relationship between Catholics and empire in the nineteenth century', paper before Catholic Historical Society of Ireland Conference, NUI Maynooth, 3 Nov. 2012.

121 The Times, 9 Apr. 1867; Edmund Sheridan Purcell, Life of Cardinal Manning, Archbishop of Westminster (2 vols, London, 1895), ii, p. 700.

122 Anon., 'Annals' in Irish Catholic Directory, Almanac and Register (1880), 224.

123 John Francis Maguire, Pontificate of Pope Pius the Ninth (being the 3rd edition of 'Rome and its Ruler' continued to the Latest Moment and Greatly Enlarged) (London, 1870); Justin McCarthy, Pope Leo XIII (London, 1896), pp. 89-90; Bernard O'Reilly, Life of Leo XIII. From an Authentic Memoir published by his order with the Encouragement, Approbation and Blessing of His Holiness the Pope (London, 1903), p. 129; James F. Talbot, Pope Leo XIII. His Life and Letters from Recent and Authentic Sources (Boston, 1886), pp. 129-30.

124 Emmet Larkin, The Roman Catholic Church and the Creation of the Modern Irish State 1878-1886 (Dublin, 1975), p. 257.

125 Croke's account features in William Scawen Blunt, The Land War in Ireland being a Personal Narrative of Events (London, 1912), p. 280. As Lawrence McCaffrey has noted, Davitt gave a different version of the encounter, though he was not present, and relayed only what Croke had told him. Michael Davitt, The Fall of Feudalism in Ireland: Or, the Story of the Land League Revolution (Dublin, 1904), p. 400; Lawrence J. McCaffrey, Irish Nationalism and the American Contribution (New York, 1976), p. 420.

126 Larkin, Consolidation, pp. 284-5. [The letter is originally in Italian]

127 Ibid., pp. 282-3. Larkin sees this letter as Cullen 'cover[ing] the exposed Roman flank' in light of Lynch having in effect 'report[ed] the Irish bishops to the Pope for not making greater temporal efforts on behalf of their 
people. That is arguably too dramatic an interpretation. Criticism of the Irish hierarchy in the pamphlet itself is muted, though Lynch was more cutting in a letter to Kirby. I.C.R.A., Kirby papers, KIR/1864/96, letter from Lynch to Kirby, 12 May 1864. In any case, Cullen's response to Lynch was a note of genuine thanks for his 'valuable letter'. D.D.A., Cullen papers, outgoing letter book 121/4, letter from Cullen to Lynch, 13 May 1864.

128 Stortz, 'Archbishop Lynch's The Evils of Wholesale and Improvident Emigration', p. 15.

129 FJ., 19 Oct. 1864 . Cullen repeated these sentiments privately in a letter to his niece Margaret in 1870 when he wrote 'religion has gained by the sufferings which our poor people have had to undergo at home'. Peadar MacSuibhne, Paul Cullen and his Contemporaries, v, p. 36.

130 F.J., 27 Nov. 1863; C.D.A., Leahy papers, 1872/13: microfilm, N.L.I., p. 6010-13, Patrick Leahy, Sermon preached at the Consecration of the Right Rev. Dr Moran, 1872.

131 Dr Cullen, Pastoral Letter to the Catholic Clergy and Laity of the Diocese of Dublin, on the Fast of Lent, 1853 (Dublin, 1853).

132 Mary Peckham Magray, The Transforming Power of the Nuns: Women, Religion, and Cultural Change in Ireland, 1750-1900 (Oxford, 1998), pp. 101-4.

133 See Cullen to Sisters of Mercy, Rathdrum, F.J., 16 Sept. 1867; The Nation, 1 Mar. 1884.

134 Peadar MacSuibhne, Paul Cullen and his Contemporaries, iii, pp. 247-8.

135 I.C.R.A., Kirby papers, KIR/1892/190, letter from Catherine Aherne to Kirby, 4 Apr. 1892.

136 Larkin, 'The devotional revolution in Ireland', pp. 625-52; Connolly, Religion and Society, p. 54. For discussion of other possible causes of the devotional revolution see David W. Miller, 'Irish Catholicism and the Great Famine' in Journal of Social History, ix (Sep. 1975), 81-98; David W. Miller, 'Landscape and Religious Practice: A Study of Mass Attendance in Pre-Famine Ireland' in Éire-Ireland, xl:1\&2 (Spring/Summer 2005), 90-106; Eugene Hynes, 'The great hunger and Irish Catholicism', 137-56; S.J. Connolly, 'Cardinal Cullen's other capital: Belfast and the 'devotional revolution" in Keogh and McDonnell, Cardinal Paul Cullen and his World, pp. 289-307.

137 Cormac Begadon, 'Catholic religious publishing, 1800-91' in James H. Murphy (ed.), The Oxford History of the Irish Book. Vol. IV: The Irish Book in English 1800-91 (Oxford, 2011), pp. 371-8.

138 Connolly, Priests \& People, pp. 77-8; Donal A. Kerr, Peel, Priests and Politics: Sir Robert Peel's Administration and the Roman Catholic Church in Ireland, 1841-1846 (Oxford, 1982), pp. 49-50; Thomas McGrath, Religious Renewal and Reform in the Pastoral Ministry of Bishop James Doyle of Kildare and Leighlin, 1786-1834 (Dublin, 1999), pp. 140-7. On 
the further development of parish lending libraries see Amy McKinney, 'Joseph Dixon and the Archdiocese of Armagh, 1852-66' (PhD thesis, QUB, 2008), pp. 92-4.

139 'New books' in Irish Monthly, xiii:146 (Aug. 1885), 443.

140 Fanning, Irish Voice in America, p. 77.

141 Mary Heimann, Catholic Devotion in Victorian England (Oxford, 1995), p. 163

142 Anon., 'New books' in Irish Monthly, viii:85 (July 1880), 404; The book was Eleanor C. Donnelly Pearls from the Casket of the Sacred Heart of Jesus (New York, Cincinnati, St Louis, 1880) and the journal Ave Maria, published at Notre Dame.

143 Anon., 'New books' in Irish Monthly., viii:79 (Jan. 1880), 56.

144 Manual of the Sodality of the Sacred Heart of Jesus (Baltimore, 1874); History of the Sodality of the Blessed Virgin Mary (Boston, 1885); Manual of the Confraternity of Our Lady of Compassion (London, 1898); Begadon, 'Catholic religious publishing', p. 377; S. Brown, 'How to work a sodality' in Irish Monthly, liii:626 (Aug. 1925), 429-32.

145 Bernard O'Reilly, The Mirror of True Womanhood: A Book of Instruction for Women in the World (New York, 1882). This had a men's equivalent: Bernard O'Reilly, True Men as We Need Them: A Book of Instruction for Men in the World (New York, 1878).

146 Clerical manuals reviewed included Priests of St Paul, Five Minute Sermons for the Low Masses on all Sundays of the Year (New York, 1880); American Ecclesiastical Review, Manual of Ceremonies for the Episcopal Visitation of Parishes, and the Administration of the Sacrament of Confirmation (New York[?], 1897).

147 Gearóid Ó Tuathaigh, 'Language, ideology and national identity' in Joe Cleary and Claire Connolly (eds), The Cambridge Companion to Modern Irish Culture (Cambridge, 2005), p. 45.

148 Thomas P. Kennedy, A History of Irish Catholicism, v: The Church since Emancipation: 8 Church Building (Dublin, 1970), p. 8.

149 Emmet Larkin, 'Economic growth', 858; Myles O’Reilly, Progress of Catholicity in Ireland in the Nineteenth Century being a Paper read before the Catholic Congress of Mechlin, September, 1864 (Dublin, 1865), p. 24; Keenan, Catholic Church, p. 119

150 William Carleton, Traits and Stories of the Irish Peasantry (3 vols, Dublin, 1834), ii, p. 161; Hall, Ireland, ii, pp. 18-19. However, thatched chapels could certainly still be found in the post-Famine landscape. The Nation, 7 June 1854.

151 Larkin, 'Devotional revolution', 644-5.

152 Keenan, Catholic Church, p. 124; Yates, Religious Condition, p. 214; Churchbuilding at this time had, as Oliver Rafferty has noted, particular significance in the North, where it 'indicated the refusal of Ulster Catholicism 
to be seen as second best,' Oliver P. Rafferty, Catholicism in Ulster 1603-1983 (Dublin, 1994), p. 150.

153 Craig, Real Pictures of Clerical Life, p. 118.

154 Simpson, Annals of my Life, pp. 123-5.

155 See Killen, Memoir, p. 174 for similar sentiments.

156 B.N.L., 20 Jan. 1854.

157 F.J., 31 Oct. 1842.

158 Other Protestant denominations, including Methodists, continued occasionally to use this fundraising method. John Ker, The Clarke Memorial Church, Portrush (Glasgow, 1887), p. 28; Dudley Levistone Cooney, The Methodists in Ireland A Short History (Dublin, 2001), p. 235

159 Ignatius Murphy, 'Building a church in 19th century Ireland' in The Other Clare, ii (Apr. 1978), 20-5. Political candidates' donations to priests were criticised by the Independent Irish Party as making clerics 'beholden' to politicians. F.J., 29 Sept. 1853.

160 I.C.R.A., Cullen papers, CUL/1837/368a, letter from Browne to Cullen, 19 Aug. 1837; Ibid., CUL/1841/692, letter from Higgins to Cullen, 8 Nov. 1841.

161 St Mel's cathedral was, not unusually, not finally completed for another fifty years. F.J., 12 May 1889. One local historian noted that Higgins had also been given unprecedented leave by other Irish bishops to fundraise in their dioceses. Perhaps the scale of his ambition for what he felt would be 'the most extensive and most elegant church of modern times, in any part of the United Kingdom' impressed other prelates, even if this avowedly Roman temple does not seem entirely at home in its modest surroundings. Peter Galloway notes, 'it looks as though it was put here by mistake. M. J. Masterson, 'Centenary of St Mel's cathedral, 1840-1940' in Ardagh and Clonmacnoise Antiquarian Journal, ii:7 (1940), 59; James MacNamee, History of the Diocese of Ardagh (Dublin, 1954), p. 436; Peter Galloway, The Cathedrals of Ireland (Belfast, 1992), p. 171; Yates, Religious Condition, p. 247.

162 The Synodical Address of the Fathers of the National Council of Thurles to their Beloved Flock, the Catholics of Ireland (Dublin, 1850), p. 11.

163 Anon., 'Address of the Catholic University Committee to their brethren in America' in Battersby's Catholic Register (1852), 184-6.

164 F.J., 12 July 1851.

165 F.J., 22 Feb. 1853; P.R.O.N.I., Clogher Diocesan Records, DIO(RC)1/11 $\mathrm{B} / 2$, Diary of Rev. Dr James Donnelly, written during fundraising trip in America, 1852-53.

166 Hearne was the only collector with an English parish and the only one not to return home, taking on a vacant parish in Massachusetts. Anon., 'Very Rev. Daniel Hearne' in Catholic Directory, Almanac and Registry (1866), 402. 
167 U.N.D.A., Odin papers, VI-2-g-A.L.S.-4pp.-12mo.-3, letter from Bartholomew Woodlock to Archbishop John Mary Odin, New Orleans, 4 Sept. 1863; I.C.R.A., Kirby papers, KIR/1864/26, letter from William Keane to Kirby, 8 February, 1864.

168 See, for example, U.N.D.A., Purcell papers, II-4-1, letter from Cullen to Purcell, Cincinnati, 8 July 1851; U.N.D.A., Blanc papers, V-1-b, letter from Cullen to Anthony Blanc, New Orleans, 8 July 1851; U.N.D.A., Lefebvre papers, III-2-h, letter from Cullen to Peter Paul Lefebvre, Detroit, 8 July 1851.

169 F.J., 1 July 1851, 16 Oct. 1851, 13 Nov. 1851.

170 F.J., 30 Aug. 1851.

171 Patrick Leahy, 'Dr Leahy's inaugural lecture as vice-rector of the Catholic University, 16 Nov. 1854' in Catholic University Gazette, i:34 (Jan. 1855), 285.

172 Shelley Barber (ed.), The Prendergast Letters: Correspondence from Famine-era Ireland, 1840-1850 (Amherst, 2006); FJ., 4 Oct. 1847, 9 Oct. 1847.

173 Murphy, Diocese of Killaloe, 1800-1850, pp. 295-6.

174 John F. Quinn, Father Mathew's Crusade: Temperance in NineteenthCentury Ireland and Irish America (Boston, 2002), pp. 168-9; Maguire, Fr Mathew, p. 256.

175 F.J., 6 Oct. 1857, 28 Feb. 1899, 8 Nov. 1860.

176 Murphy, Diocese of Killaloe, 1850-1914, pp. 69-70.

177 St Patrick's Armagh, for example, necessitated collections in the United States in 1854, 1856, 1868 and 1900. A.D.A., Dixon papers, II Box 1, Folder 2, letter from Archdeacon Felix Slane to Dixon, 4 Dec. 1854; F.J., 26 June 1856; (A.D.A., Kieran papers, 1 Mar. 1868); Brooklyn Daily Eagle, 11 Mar. 1900.

178 F.J., 8 Nov. 1853, 24 May 1869; Anthony Cogan, The Ecclesiastical History of the Diocese of Meath Ancient and Modern (3 vols, Dublin, 1867), ii, p. 498; FJ., 5 Dec. 1881. U.N.D.A., Hudson papers, X-2-j-A.L.S.-4pp.$12 m o .-\{1\}$, letter from Edward Murphy S.J., Galway to Fr Daniel Hudson, Notre Dame. 15 Aug. 1882; Devine, 'Jolly beggar'.

179 F.J., 24 May 1887; U.N.D.A., Lefebvre papers, III-2-1-Printed-L.S.1p.-4to.- $\{1\}$, letter from Nicholas Conaty to Bishop Paul Lefevere, 12 Oct. 1868 .

180 F.J., 28 Feb. 1854.

181 These include churches at Askeaton, Co. Limerick, St Johnston, Co. Donegal, Clogheen, Co. Tipperary, Louisburg, Co. Mayo, Manorhamilton, Co. Leitrim, Clonea, Co. Waterford, Crosserlough, Co. Cavan, Omagh, Co. Tyrone and Castlerea Co. Roscommon. F.J., 10 July 1851, 3 Oct. 1855, 6 Jan. 1859, 17 Oct. 1860, 20 Oct. 1885, 26 Nov. 1888, 19 June 1893, 2 Oct. 1899. 
182 O'Rorke, History of Ballysadare, p. 498; Cogan, History of the Diocese of Meath, ii, p. 495. Those mentioned in the Kirby collection include chapels at Lurgan, Co. Armagh, Clonmel, Co. Tipperary, Eniskean, Co. Cork, Donegal Town and Carrick-on-Shannon, Co. Leitrim. I.C.R.A., Kirby papers, KIR/1872/298, letter from J. P. Leahy to Kirby, 24 October, 1872; Ibid., KIR/1873/54, letter from P. F. Flynn to Kirby, 5 Feb. 1873; Ibid., KIR/1873/89, letter from D. Covenly to Kirby, 4 Mar., 1873; Ibid., KIR/1874/86, letter from P. Kelly to Kirby, 24 February, 1874; Ibid., KIR/1874/217, letter from Thomas Fitzgerald to Kirby, 3 May, 1874.

183 This fateful story was related by William Hague at the inquest into the death of Fr Kavanagh, P.P. of Rathangan, Co. Kildare. The blackly ironic verdict: death by a blow to the head from a falling altar statue. F.J., 7 Oct. 1886.

184 F.J., 31 Jan. 1854.

185 'Property of the working classes in America' in Dublin Builder (Sept. 1859), 118.

186 F.J., 3 Nov. 1890.

187 Catholic Telegraph, 26 May 1860; Alfred P. Smyth, Faith, Famine and Fatherland in the Irish Midlands: Perceptions of a Priest and Historian, Anthony Cogan, 1826-1872 (Dublin, 1992), pp. 147-8; F.J., 1 July 1858.

188 For the virulent, anti-clerical take of a Catholic barrister and polemicist see Michael J. F. McCarthy, Priests and People in Ireland (Dublin, 1902), p. 262. This kind of criticism has continued to rear its head periodically. In 1966, a T.C.D. student, Brian Trevaskis, notoriously called the Bishop of Galway 'a moron' on R.T.E. television's Late Late Show, for spending money on building a 'monstrosity' of a cathedral instead of on the poor. Irish Times, 29 Mar. 1966; Marcus Tanner, Ireland's Holy Wars: The Struggle for a Nation's Soul, 1500-2000 (Dublin, 1999), p. 162. More recently, the bishop of Ardagh was criticised for soliciting donations from 'vulnerable' confirmation candidates for the rebuilding of the firedamaged St Mel's cathedral in Longford. Irish Independent, 17 May 2010.

189 Horace Plunkett, Ireland in the New Century (London, 1904), pp. 107-9. As Plunkett's biographer observes, close friends, among them a Jesuit priest, advised strongly against these passages. Trevor West, Horace Plunkett: Co-operation and Politics, An Irish Biography (Washington, 1986), p. 72; M[ichael] O'Riordan, Catholicity and Progress in Ireland (London, 1906), p. 30.

190 Robert Elliott, Art and Ireland (Dublin, 1904), pp. 266-8; Michael F. J. McDonnell, Ireland and the Home Rule Movement (Dublin, 1908), p. 114.

191 P. F. Moran, The Priests and People of Ireland (Melbourne, 1904), p. 18.

192 See Larkin, 'Economic growth', p. 865.

193 Fr Peter Conway, parish priest of Headford, Co. Galway built his chapel 
entirely from the proceeds of three trips made to the United States in the early 1860s. He consequently attempted to nickname it 'the IrishAmerican church', but the moniker failed to endure, presumably because it was far from unusual for a church to be thus financed. FJ., 23 Mar. 1861.

194 Nigel Yates records that Batt O'Connor's trip raised $£ 837$ of the $£ 15,000$ cost of Killarney cathedral. Yates, Religious Condition, p. 248; Frs Hegarty and McKenna collected $£ 2,000$ of the $£ 40,000$ cost of Derry cathedral. Stephen McLoughlin, 'The development of the cathedral church in Derry under the leadership of Bishop Francis Kelly (1849-1888): a study of stewardship' in Henry A. Jeffries and Ciarán Devlin (eds), Derry from Earliest Times (Dublin, 2000), p. 231; Peter Galloway, citing no source, claims that only $£ 4,000$ of the $£ 45,000$ it took to build Thurles cathedral was raised abroad. Galloway, Cathedrals of Ireland, p. 203.

195 Nolan, Ourselves Alone, p. 87; Diner, Erin's Daughters, pp. 137-8; Stephen Thernstrom, Poverty and Progress: Social Mobility in a Nineteenth Century City (Cambridge, MA, 1964), pp. 175-6; Charles R. Morris, American Catholic (New York, 1997), pp. 17-18; Lynch-Brennan, Irish Bridget, p. 140; A.D.A., Dixon papers, Box 2 Folder 14, appeal by Dixon in favour of completion of St Patrick's Cathedral, Armagh, 2 Mar. 1863.

196 Michael Buckley, collecting for Cork cathedral, met this problem on several occasions. Buckley, Diary, pp. 137-40.

197 C.D.A., Leahy papers, 1867/26: microfilm, N.L.I., p. 6010-13, letter from Cardinal McCloskey to Archbishop Leahy, 1867; McCloskey also refused permission to Pius Devine to collect; Devine, 'Jolly beggar'; I.C.R.A., Kirby papers, KIR/1864/28, letter from Woodlock to Kirby, 10 Feb. 1864; Ibid., KIR/1873/54, letter from P. F. Flynn, Clonmel, to Kirby, 5 Feb. 1873; Ibid., KIR/1880/310, letter from J. Maher, Dublin to Kirby, 28 June, 1880; Ibid., KIR/1881/136, letter from James McCarthy, Queenstown to Kirby, 8 May, 1881.

198 American parish clergy are variously described by Devine as 'more Turkish than Christian with regard to beggars', 'gruff, stiff, and stubborn, determined that he would not aid, 'an old, smug, comfortable gentleman'. Devine, 'Jolly beggar'.

199 O'Riordan, Catholicity and Progress, pp. 36-7.

200 Buckley, Diary, p. 100, p. 114.

201 I.E.D., Doran letters, Doc. no. 107161, letter from Jane Doran to William [Doran?],30 Mar. 1870; Barber, Prendergast Letters, pp. 128-9; Cara Delay, "'The gates were shut": Catholics, chapels, and power in late nineteenthcentury Ireland' in New Hibernia Review, xiv:1 (Spring 2010), 27.

202 Grace Neville, "She never then after that forgot him': Irishwomen and emigration to the United States in Irish Folklore' in Mid-America, lxxiv:3 (Oct. 1992), 280. 
203 U.N.D.A., Purcell papers, II-4-m-A.L.S.-5pp.-16to.-\{8\}, letter from Brummer to Purcell, 18 May 1854. For fundraising methods used by American priests see Lawrence W. McBride, 'The Reynolds letters: sources for understanding the Irish emigrant experience in America and England, 1865-1934' in Charles Fanning (ed.), New Perspectives on the Irish Diaspora (Carbondale, 2000), p. 136.

204 F.J., 30 Jan. 1866. On political fundraising among the diaspora see Keyes, Funding the Nation, pp. 100-3; 109-42; M.V. Hazel, 'First Link: Parnell's American Tour, 1880' in Éire-Ireland, xv:1 (Spring 1980), 6-24; Niall Whelehan, The Dynamiters: Irish Nationalism and Political Violence in the Wider World, 1867-1900 (Cambridge, 2012), pp. 70-137; for a comparison of family, political and religious remittances, see Alan O'Day, 'Imagined Irish communities: networks of social communication of the Irish diaspora in the United States and Britain in the late nineteenth and early twentieth centuries' in Enda Delaney and Donald M. MacRaild (eds) Irish Migration, Networks and Ethnic Identities since 1750 (London, 2007), pp. 264-6. 


\section{Conclusion}

In 1902, shortly after the Irish Catholic bishops jointly issued what seemed a definitive, downbeat resolution on the 'ruinous' outflow of the previous half-century, the Irish Ecclesiastical Record also played host to a transatlantic clerical spat on the same subject. ${ }^{1}$ Initiated by the idiosyncratic American dispatches of a Dublin-based Oblate mission Father, M. F. Shinnors, and answered by an Irish-American priest, John Talbot Smith, the row was in several respects nothing new. Just as Shinnors rehashed the careworn arguments about Irish Catholic apostates that 'may be counted by the million', Smith countered in familiar terms that such claims were exaggerated, and, in any case, if true, 'the explanation of apostasy will have to be made by their leaders at home.'

These lines - the meat of their arguments - were well rehearsed, but the two men also offered further hallmarks of the Irish priest's view of emigration from Ireland. Smith suggested that while the Irish migrant would find no better home than the United States, he should 'consider change carefully, study the matter soberly, make shrewd preparations, and not let go of the bird in the hand until quite sure of the two in the bush'. Shinnors, meanwhile, dispensed clichés like Hail Marys at a Novena; on one hand Irishmen could be justly proud of having contributed so much towards the fabric of the 'great' nation, while on the other, the defective 'moral atmosphere' of the country presented a danger to their faith, the Irish failed to thrive as immigrants compared with other national groups, and the particular innocence of the Irish female emigrant put her in the path of evil. He made the not unprecedented and morally questionable claim that those Famine migrants, 'whose uncoffined bones lie at this moment in the depths of the ocean' underwent an 'enviable fate' compared to those who made it across 
but lost their religion, he felt sure that an Irish legislature would certainly stop the drain of people from Ireland, and he urged that in the meantime Irish priests really ought to devote a Sunday sermon or two to railing against, and attempting to prevent, emigration. ${ }^{3}$

If Shinnors was hardly original in any of this, neither was the wider reaction his reports prompted. Although additionally dismissed as the 'extravagant estimate' of a 'superficial observer' by American Catholic commentators, Shinnors' figure of ten million lapsed emigrants found credulous ears among those whose anti-Catholic or anti-clerical arguments it appeared to buttress. ${ }^{4}$ The Irish anti-clerical polemicist Michael McCarthy accepted not only that 'Irish immigrants in America desert in millions' but that they were far better off for doing so, while the former priest (and one of G. K. Chesterton's Heretics), Joseph McCabe, employed Shinnors' estimates in his account of The decay of the Church of Rome. ${ }^{5}$ Most notably, Horace Plunkett's unquestioning citation of Shinnors' testimony in the controversial Ireland in the new century was attacked by Monsignor O'Riordan in his lengthy answering volume on the basis that Shinnors had 'little more than passed through' the United States. ${ }^{6}$ That point was a reasonable one, but there was also a clear sense from O'Riordan that any idea that emigrants abandoned the faith could, regardless, not be accepted from a Protestant commentator such as Plunkett, no matter how sympathetic he otherwise appeared.

Although this incident was muted in comparison with earlier controversies of a similar nature - the Mullen and Lynch letters in particular - the very fact of its taking place illustrates an often unknowing repetition in Catholic clerical responses to emigration. From Bishop England in the 1830s, to Fr Shinnors at the turn of the century, it seemed each generation produced at least one Catholic clergyman who purported to prove anew that Irish emigrants had deserted and were deserting their faith in vast numbers, and consequently urged Irish priests to do something they patently could not: stop the exodus. While it was sometimes clear that the authors of these claims were aware of their place in this succession - John England's dubious contribution, in particular, was given due credit they seemed blind to the fact that such interventions rarely had the intended effect. If the hope was that giving public voice to concerns about 'leakage' among emigrants would strengthen the resolve of the Irish church against emigration, it was to little end. As was observed in Chapters One and Two, clergy could influence would-be migrants 
only in the manner of their departure; stemming the flow altogether was beyond even their divinely sanctioned power. Instead, such reports had their greatest impact in acting as grist to the mills of the Catholic Church's opponents, whether Protestant evangelicals or lapsed Catholic anti-clericals.

In another sense, however, the undertones of the Shinnors row illustrate the more favourable consequences of emigration for the Catholic Church. Despite the main thrust of his reports, the Oblate mission in the United States was a resounding success, packing the churches in the parishes it visited to the point of having to divide the congregations. One week was assigned to married women, the next to unmarried women, and the same again for men, instead of the usual four weeks for all-comers. These people, Shinnors observed, were 'as full of faith and fervour as if they still lived in their own homes. ${ }^{7}$ Moreover, two of his American clerical critics, Smith and John Ryan, were the American-born sons of an Irish railroad worker and an Irish farmer respectively. Each rose to prominence not merely as priests, but, in Smith's case, as the best Irish-American clerical novelist of the late nineteenth century - a surprisingly crowded field - and in Ryan's, as the leading social thinker in the early twentieth-century American church. ${ }^{8}$ They were living contradictions of Shinnors' wider fears, and embodiments of what Smith elsewhere described as 'the triumphs of the [Irish] race and its religion through the very exile which was intended to destroy it.' ${ }^{9}$ Such men and their flocks - as San Francisco's prominent 'labour priest' Peter Yorke forcefully impressed upon Maynooth's Walter McDonald, when the latter visited America in 1900 - looked to Ireland and her church as to the 'rising sun'; to them it was the revered monarch of an English-speaking Catholic kingdom. ${ }^{10}$

Though Yorke was chiding McDonald and the Irish church for not fully appreciating this fact, as Chapter Five demonstrated, it had in fact constructed and developed a powerful and widely accepted narrative of a 'spiritual empire' arising out of mass emigration. In that sense, the tensions the church faced when considering emigration, between expanding its ecclesiastical influence abroad and maintaining its demographic position at home, seemed substantively resolved by the turn of the century. As far as the church's own institutional interests were concerned, emigration had turned out to be a largely unsought and unanticipated boon. It helped to blunt the impact of evangelical proselytism, further increased the priest-to-people ratio 
at home, gave an outlet for ever-increasing Irish vocations, and provided, both directly and indirectly, much of the pecuniary support for the physical maintenance and expansion of the church in Ireland in the second half of the century. In that sense, for many Catholic clergymen in Ireland, the much-trumpeted 'spiritual empire' was less the altruistic, divine undertaking of their 'martyr nation' than it was the opportunistic exploitation of circumstance for home benefit: an accidental (spiritual) imperialism. Fears of empty pews or of losing demographic dominance in Ireland, so prevalent among clergy during the Famine, and occasionally during later peaks of emigration, had proved entirely unfounded. In fact, although it was not openly stated very often, mass emigration had greased the wheels of the devotional revolution, helping to increase the Irish church's power and influence both at home and abroad.

The corresponding tension the Catholic Church faced in relation to individual migrants, between what was judged to be in their best economic interest and their best spiritual and moral interest, was less easily reconciled. Despite the nature of the public rhetoric explored in Chapter One, 'opposition' does not quite cover the post-Famine reality. While the church became highly critical of the need for emigration, advocated solutions that would purportedly lessen the outflow and continued to urge individuals not to leave, there was a widespread underlying recognition that, as in other temporal matters, their influence could only be brought to bear insofar as it chimed with the existing expectations of their flocks. To that end, while some priests actively sought to ensure the safe passage of emigrants by initiating or partaking in schemes of assisted emigration, a far greater body of parish clergy responded to their parishioners in providing occasionally reluctant, but often vital facilitation of independent migration. In particular, the priest's role in kick-starting local 'chains' of emigration by soliciting passage money and handling correspondence and remittances should be acknowledged as important.

Although the clergy had therefore been forced to concede that the economic imperative would always trump any cautionary tales of spiritual ruin they had cause to dispense, as the hierarchy's 1902 statement shows, they did not stop dispensing them. In a sense, however, this was simply a reinforcement of the standard advice that the clergy offered to emigrants, whether in guidebooks, sermons or conversation. It encouraged would-be emigrants to weigh their options carefully: was it worth risking salvation in the next life for the possi- 
bility of a better situation in this one? An overwhelming majority, ground down by persistent poverty or jolted by sudden crisis decided that it was, as most priests who asked that question surely knew they would. Emigrants had been reminded, nonetheless, of the gravity of the decision they were making - a point which clergy felt could sometimes be lost in the headlong 'mania' of chain migration - and had had it affirmed that religious observance in their new homes would require considerable personal effort on their parts.

The most the Irish church could do in practical religious terms was endeavour to ensure that those who left would and could make such an effort. Organised welfare measures, designed to stave off the worst of spiritual and moral dangers at ports and at sea, were surprisingly lacking, however. At no time did the Irish Catholic Church as a body either originate or lend wholehearted support to adequate emigrant welfare initiatives, although individual clergy doubtless made a difference to the fate of many vulnerable migrants. This reluctance to commit what were acknowledged to be necessary resources to the departing extended also to the departed. While in purely numerical terms the Irish church's pastoral efforts on behalf of the diaspora were extensive, as Chapter Three argues, in practice they were carried out on a shoestring, at the periphery of the church's ecclesiastical structures, and with little regard to the quality of religious personnel sent abroad.

There may, therefore, seem to have been a disparity between the actions and the rhetoric of the Catholic Church in relation to emigration. How could emigrants carry out their supposedly providential mission to propagate an alternative Irish Catholic 'empire' across the English-speaking world while imperfectly attended by what many privately regarded as the clerical rejects of the home church? This seeming contradiction can be explained. Firstly, it is important to note that as the century wore on, the church became increasingly conscious of the need to ensure that would-be emigrants - which meant a significant proportion of every generation - were as thoroughly instructed in the faith as possible at home. An early and strict indoctrination of Catholic principles, it was recognised, would help keep them in the fold if they were ever to find themselves adrift from regular ministrations. Thus the response to the common criticism from priests abroad, the likes of Mullen and Smith included, that the Irish church had failed emigrants in religious terms before they ever left Ireland was in fact largely addressed as the devotional revolution took hold. Secondly, it ought to be acknowledged that 'bad priests' of the kind 
churned out by All Hallows need not have, and indeed, likely did not, engender mass apostasy among the Irish Catholic diaspora. They may have made for uninspiring religious experiences, or been the gatekeepers of insular 'national parishes' that impeded assimilation into the host society, but they also manned churches that were more often than not packed to the rafters.

The significance of the Irish church's reluctance to despatch better priests to meet the needs of the diaspora therefore lies in what it says about that church's priorities rather than in its tangible effects. The chief concern of the Irish Catholic Church was, unsurprisingly, the Irish Catholic Church. In that context, any efforts by the clergy to do their duty in relation to emigrants' spiritual well-being could only be half-hearted, and driven by individuals rather than the church as a body, notwithstanding their shrill chorus of public demands for the fullest engagement of the government and landlords in solving the emigration problem. An accurate recognition that the church could itself do little or nothing to prevent or reduce the outflow, prompted widespread, unofficial attempts to smooth the process for emigrants, but to clergymen at all levels of the church, it was the potential consequences of emigration for their own institution that was their primary worry. That these consequences turned out to be, on balance, positive, and that many contemporary clergymen understood that fact, needs to be emphasised.

By comparison, at the end of the nineteenth century the two main Protestant churches looked back on decades of emigration with considerably more mixed feelings. The respective responses of Anglicans and Presbyterians had to some extent followed the same path to different conclusions. From the 1830s, both sets of clergy allowed a sober recognition of the economic benefits for individual emigrants to win out over any worries for the spiritual dangers they may have faced. Clergy of both churches helped facilitate emigration, and each church subsequently made formal attempts to supply their departed brethren with clergy, and, less extensively, to safeguard their welfare in transit, although these efforts suffered from the same shortcomings in personnel and financing as those of the Catholic Church. Indeed, it was the effect of emigration on the home churches which once again proved to be of most concern. What particularly exercised Protestant ministers who disdained emigration before the Famine was the sense that it was born of persecution by Catholic neighbours and neglect by Protestant landlords and politicians, and the fear that those left behind 
would become an ever more marginalised rump within Ireland. This had given way to a fervent hope, in great measure encouraged by astronomical levels of Catholic emigration from the middle decades of the century, and bolstered by parallel efforts to convert Catholics, that Protestants would not merely escape this fate, but might even greatly increase their relative demographic strength on the island. As the 'Second Reformation' faltered in the early 1850s, however, evangelical conceptions of emigration were again adapted. Though there was considerable regret at the apparent emigration of many converts - some genuine, some less so - as a result of the Catholic 'counter-Reformation', their leaving also allowed the development of a new narrative, which saw all Catholic emigration as a providential prelude to conversion, a view only reinforced by often inaccurate reports of apostasy emanating from Catholic clergy abroad.

At this point, however, the paths of the two churches began to diverge. After the 1861 census, for all its disputed methodologies, had confirmed the relatively meagre demographic gains made by the Protestant churches, the Church of Ireland, in spite of having had the smallest proportional losses since 1834, was unable to prevent its own disestablishment. While active Irish Anglican participation in the empire via emigration was seen by some commentators as 'not a loss but a benefit - not a weakness but a source of strength to the nation', it was in fact small comfort for this blow. ${ }^{11}$ From disestablishment onward, and particularly outside of Ulster, continued emigration helped to send many parishes and dioceses of the Church of Ireland into a spiral of demographic decline. Though many of the worst predictions of the antidisestablishmentarians had not come to pass, ${ }^{12}$ the feeling of the Meath vicar John Healy in 1908 that 'the outlook is not promising' was an understated summing up of the demoralised position of elements of the depleted and disestablished Church of Ireland. Emigration, in the end, had not been as kind to the church as overall population ratios suggested. The five decades after the 1861 census saw Anglicans further increase their share of the population from just under $12 \%$ to just over $13 \%$, but numbers were down in real terms by well over 100,000 and those left behind were increasingly confined to Ulster. ${ }^{13}$ Well into the twentieth century, Church of Ireland commentators tended to regard emigration from their congregations as a lamentable loss that had to be, somehow, arrested. ${ }^{14}$ Moreover, it was a loss from which, unlike the Catholic Church's, no particular compensating remittance benefit appeared to flow..$^{15}$ 
By contrast, while many Presbyterian ministers had harboured the same dream of a more religiously balanced population, and been equally disappointed by its unravelling, they appeared to look on the emigration of their own brethren with something approaching equanimity. In 1901, the noted Presbyterian author and minister W. D. Killen could write that 'During the nineteenth century, the Irish Presbyterian Church has been considerably affected by emigration. [...] Notwithstanding this draft on its resources, it at present holds perhaps a higher position in the country than it ever occupied before. In common with other denominations its population has of late declined; but its ministers and congregations since the beginning of the century have more than doubled. ${ }^{16}$ Like Catholic clergy, Presbyterians could therefore identify significant ways in which, despite its losses, their church had profited by emigration. Not least of these was the fostering of transatlantic relations which had been so important in initiating the transformative 1859 Revival in Ulster, but there were also, as one Irish minister later noted, significant remittance implications for the Irish Presbyterian Church. ${ }^{17}$

Therefore, to suggest in conclusion that clerical attitudes towards emigration after 1815 were considerably more complex than William Adams' clear-cut view of cross-denominational 'opposition' is surely warranted. Ultimately, there was no single Anglican, Presbyterian or Catholic view of emigration, which translated into the rather mundane reality that different contexts called for different responses from different - and sometimes the same - clergy. Thus, the Church of Ireland rector William Hickey could tell Parliament that emigration was the answer to Irish poverty, while acknowledging, in his pseudonymous guise of Martin Doyle, the personal hardships and heartaches of exile for Protestant and Catholic alike; the Presbyterian minister John Brown of Aghadowey could denounce government emigration advocates as 'drivelers' yet later produce a sermon that advised his congregation on how best to emigrate; and the Catholic Archbishop of Cashel, Patrick Leahy, could see the renewed crisis emigration following the 1860s harvest failures as a harbinger of the loss of the Catholic nation, but a few years later look back on it as an element of a divine mission of the Irish race. These responses sometimes had their parallels across denominational lines, they were sometimes unique to one sect, and they were occasionally a feature of underlying Protestant and Catholic conflict, but they also show, in the end, that the Irish churches and their clergy, for all of their various 
opinions and actions on the subject, shaped emigration far less than they were shaped by it.

\section{Notes}

1 'Resolutions of the standing committee of the Irish archbishops and bishops on emigration and its remedies' in I.E.R., 4th ser., xi (May 1902), 475-7.

2 M. F. Shinnors, 'Ireland and America: some notes on a mission tour in the United States, I' in I.E.R., 4th ser., xi (Feb. 1902), 123-4; John Talbot Smith, 'The Irish in the United States' in I.E.R., 4th ser., xi (June 1902), $532-44$.

3 See FJ., 7 Mar. 1894, for P. Larkin O'Neill's opinion that 'it would have been better for tens of thousands of Irish Catholics to have starved to death in Ireland than ever to have set foot on our shores'.

4 John A. Ryan, 'Is the modern spirit anti-religious?' in Catholic World, lxxxv:506 (May 1907), 183; Patrick J. Healy, 'Book reviews' in Catholic University Bulletin, x:3 (July 1904), 405.

5 McCarthy, Priests and People, p. 596; this contrasted with McCarthy's reluctant admission in 1901 that a majority of emigrants did not reject Catholicism; Shinnors had given him the 'proof' to go further. Michael J. F. McCarthy, Five years in Ireland, 1895-1900 (Dublin, 1901), p. 79; Gilbert K. Chesterton, Heretics (London, 1905), pp. 216-33; Joseph McCabe, The Decay of the Church of Rome (London, 1909), pp. 179-81. See also Randolph H. McKim, Romanism in the Light of History (New York, 1914), p. 17.

6 Plunkett, Ireland in the New Century, p. 111; O'Riordan, Catholicity and Progress in Ireland, p. 259.

7 Shinnors, 'Ireland and America', p. 119.

8 Fanning, Irish Voice in America, p. 189; Charles E. Curran, Catholic Moral Theology in the United States: A History (Washington, 2008), p. 64.

9 John Talbot Smith, The Chaplain's Sermons (New York, 1896), pp. 75-6 as cited in Matthew Frye Jacobson, Special Sorrows: The Diasporic Imagination of Irish, Polish and Jewish Immigrants in the United States (London, 2002), p. 67.

10 Walter McDonald, Reminiscences of a Maynooth Professor, ed. Denis Gwynn (London, 1925), p. 215.

11 Anon., 'The Irish Church: her "reformers" and her foes' in Dublin University Magazine, lxiii:376 (Apr. 1864), 369.

12 Lee, Facts Respecting the Present State of the Church in Ireland, passim; John Macbeth, The Story of Ireland and her Church from the Earliest Times to the Present Day (Dublin, 1899), pp. 309-19.

13 John Healy, History of the Diocese of Meath (2 vols, Dublin, 1908), ii, 
p. 251; Vaughan and Fitzpatrick, Irish Historical Statistics, p. 49.

14 Bolton C. Waller, Hibernia or the Future of Ireland (London, 1928); R. P.

McDermott and D. A. Webb, Irish Protestantism To-day and To-morrow. A Demographic Study (Dublin and Belfast, c. 1946).

15 Nor was it needed: the favourable disestablishment financial arrangements, and the relative prosperity of those Irish Anglicans who remained, ensured a steady, homegrown income. Gerald Parsons, 'Irish disestablishment' in Gerald Parsons (ed.) Religion in Victorian Britain II Controversies (Manchester, 1988), pp. 124-46.

16 W. D. Killen, Reminiscences of a Long Life (London, 1901), pp. 247-8; see also The Witness, 24 June 1881.

17 John Macmillan, D.D., Irish Presbyterianism and American, being an Address delivered by Request in the Alexander Hall of Princeton University at the Centennial Celebration of the Theological Seminary at Princeton, N.J., U.S.A, May, 1912 (Belfast, 1913), p. 23. 


\title{
Select bibliography
}

\author{
Manuscript sources \\ All Hallows College, Dublin \\ Overseas Missionary Correspondence \\ Archive of St Paul of the Cross Retreat, Mount Argus, Dublin
}

Pius Devine papers

Armagh Diocesan Archives

Dixon papers

Kieran papers

Logue papers

Cashel Diocesan Archives

Croke papers

Leahy papers

Slattery papers

Centre for Migration Studies/Ulster American Folk Park, Omagh Doran letters

Fitzgerald letters

Neill papers

Smyth letters

\section{Dublin Diocesan Archives}

Cullen papers

Hamilton papers

Murray papers 
Irish College Rome Archives

Cullen papers

Cullen supplements

Kirby papers

National Library of Ireland

Larcom papers

Monsell of Tervoe papers

Monteagle papers

Prior-Wandesforde papers

Tracts on Popery

William O’Brien papers

Public Record Office of Northern Ireland

Aiken McClelland papers

Armour genealogical papers

Bates papers

Clay family emigrant correspondence

Clogher Diocesan Records (R.C.)

Crawford emigrant papers

Dufferin papers

Foster of Glyde papers

Greer, Hamilton and Gailey papers

Hall papers

John George Beresford papers

Kirkpatrick papers

Montgomery papers

Park and Quin papers

R. H. Elliott papers

Vere Foster papers

William John Campbell Allen papers

University of Notre Dame Archives, Indiana (online)

Blanc papers calendar

Brownson papers calendar

Hudson papers calendar

Lefebvre papers calendar

McFarland papers calendar

Purcell papers calendar

Odin papers calendar 


\section{Printed primary sources}

Newspapers and periodicals

Achill Missionary Herald and Western Witness

The Anglo-Celt

Annals of the Propagation of the Faith

Annual Reports of All Hallows/Annals of All Hallows

Armagh Guardian

The Austral Light

Banner of Ulster

Battersby's Catholic Register/Battersby's Registry for the Catholic World/ Irish Catholic Directory and Almanac

Belfast Commercial Chronicle

Belfast Mercury

Belfast News Letter

Brooklyn Daily Eagle

Brownson's Quarterly Review

Canadian Freeman

Catholic Layman

Catholic University Bulletin

Catholic University Gazette

Catholic World

Christian Examiner and Church of Ireland Magazine

Christian Freeman

Connaught Telegraph

Cork Examiner

Derby Mercury

Dublin Builder

Dublin Evening Mail

Dublin Record

Dublin Review

Dublin University Magazine

Duffy's Fireside Magazine: A Monthly Miscellany

Duffy's Irish Catholic Magazine: A Monthly Review

Edinburgh Review

Evangelical Witness and Presbyterian Review

Freeman's Journal

Galway American

Galway Vindicator

The Globe

Irish Canadian

Irish Church Directory

Irish Church Quarterly 
Irish Ecclesiastical Gazette, or Weekly Repository of Miscellaneous Church News

Irish Ecclesiastical Record

Irish Independent

Irish Monthly

Irish Penny Journal

The Irish People

Irish Presbyterian

Irish Times

John Bull

Journal of the Ivernian Society

Journal of the Statistical and Social Inquiry Society of Ireland

Limerick Herald

Limerick Reporter and Tipperary Vindicator

Manchester Guardian

Mayo Examiner

McComb's Presbyterian Almanack and Christian Remembrancer

Meath Chronicle

Missionary Herald of the Presbyterian Church in Ireland

Morning Chronicle

The Nation

New York Times

Orthodox Presbyterian

Presbyterian Churchman

Presbyterian Magazine

Quarterly Review

The Rambler: A Catholic Journal and Review of Home and Foreign Literature,

Politics, Science, Music and the Fine Arts

Roscommon Journal

Southern Star

The Tablet

The Times

Tralee Chronicle

Tuam News

Weekly Telegraph/Catholic Telegraph

Westminster Review

The Witness

\section{Church minutes}

Minutes of the Methodist Conference in Ireland

Minutes of the Proceedings of the General Assembly of the Presbyterian Church in Ireland 


\section{Official publications}

Hansard's Parliamentary Debates, ser. 3, cclxxxii (1883)

\section{Parliamentary papers}

Report from the Select committee on emigration from the United Kingdom, H.C. 1826 (404), iv, 1

Third report from the select committee on emigration from the United Kingdom, 1826-27, H.C. (550), v, 223

First report of evidence from the select committee on the state of the poor in Ireland, H.C. 1830 (589), vii, 113

Report from the select committee on the disposal of lands in the British colonies; together with the minutes of evidence, and appendix, H.C. 1836 (512), xi, 499

Poor inquiry (Ireland). Appendix (C) - Parts I. and II. Part I. Reports on the state of the poor, and on the charitable institutions in some of the principal towns; with supplement containing answers to queries. Part II. Report on the city of Dublin and supplement containing answers to queries; with addenda to appendix (A.), and communications [35-42], H.C. 1836, xxxiv, 35

Evidence taken before Her Majesty's commissioners of inquiry into the state of the law and practice in respect to the occupation of land in Ireland. Part ii [616], H.C. 1845, xx, 1 [Devon Commission]

First report of the select committee of the House of Lords on colonisation from Ireland; together with the minutes of evidence, H.L. 1847-48 (737-737-II), vi, 1

Report from the select committee on Passengers' Act; with the proceedings of the committee, minutes of evidence, appendix, and index, H.C. 1851 (632), xix, 1

Report of the select committee on outrages (Ireland); together with the proceedings of the committee, minutes of evidence, appendix and index, H.C. 1852 (438), xiv, 1

First report from the select committee on emigrant ships; with the minutes of evidence taken before them, H.C. 1854 (163), xiii, 1

Preliminary report from Her Majesty's Commissioners on agriculture [C.2778], H.C. 1881, xv, 1 [Richmond Commission]

Report from the select committee on colonisation; together with the proceedings of the committee, minutes of evidence, and appendix, H.C. 1890 (354), xii, 1

\section{Contemporary books and pamphlets}

A cabin passenger [Robert Whyte], The Ocean Plague: Or, A Voyage to Quebec in an Irish Emigrant Vessel (Boston, 1848)

A member of the Statistical and Social Inquiry Society of Ireland [John Haslam], The Real Wants of the Irish People (Dublin, 1865)

A. R. C. (A clergyman of the established church), Ireland and the Remedy for her Evils (Dublin, 1830)

An Ulster clergyman, Moral and Religious Effect of Emigration (Dublin, 1850) 
Anon. (ed.), The Tenure of Land in Ireland, abridged from the Work of The Right Hon. Lord Dufferin, K.P on that Subject; With Additions and Alterations (Dublin, 1870)

Anon., Correspondence between the Rev. D. W. Cahill, D.D. and some Protestant Ministers of the Town and Neighbourhood of Sligo, who invited him to a Public Discussion (Sligo, 1855)

Anon., Financial Report of the Irish Auxiliary to the Colonial and Continental Church Society for supplying Clergymen, Catechists, and Teachers to the Colonies of Great Britain, and to British Sojourners on the Continent for the year ending 31st December, 1870 (Dublin, 1871)

Anon., Information published by His Majesty's Commissioners for Emigration, respecting the British Colonies in North America (Limerick, c. 1833)

Anon., Missions in Ireland: Especially with reference to the Proselytising Movement: showing the Marvellous Devotedness of the Irish to the Faith of their Fathers by one of the Missioners (Dublin, 1855)

Anon., Report of the Dingle and Ventry Mission Association, County Kerry, Ireland, for the year ending $1^{\text {st }}$ December, 1847 (Dublin, 1848)

Anon., Report of the Dublin and Kildare Diocesan Auxiliary to the Society for the Propagation of the Gospel in Foreign Parts for the years 1849 and 1850 (Dublin, 1851)

Anon., Reports and Papers relating to the Proceedings of the Committee of 'Mr Tuke's Fund' for assisting Emigration from Ireland during the years 1882-83-84, collected for the Private Use of the Committee (London, 1885)

Anon., Second Report of the Emigrant Protection Society (Dublin, 1851)

Anon., Sketch of the Province of New Brunswick, published for the Use of Emigrants (Limerick, n.d.)

Anon., Summary Account of the Society for the Propagation of the Gospel in Foreign Parts (London, 1851)

Anon., The Church of England in the Colonies: A Lecture (Colchester, 1851)

Anon., The Protestant Colonisation Society of Ireland. At a Meeting of the General Committee held at the Society's Apartments, no. 15, Dame-street, on Friday, the 18th day of December, 1829 (Dublin, 1829)

Anon., The Twenty-Eighth Report of the Irish Society for promoting the Education of the Native Irish through the Medium of their own Language: for the year ending 17th March, 1846 (Dublin, 1846)

Anon., Transactions of the Protestant Colonisation Society of Ireland, reported at a Public Meeting of Subscribers, in the Dublin Institution, on May 24, 1832 (Dublin, 1832)

Anon., Yearly Statement of Missionary Progress of the Islands and Coast Society, 1852 (Dublin, 1852)

Armstrong, Thomas, My Life in Connaught with Sketches of Mission Work in the West (London, 1906)

Baldwin, [Thomas], A Remedy for the Congested Districts of Ireland. Migration 
Versus Emigration (Dublin, 1884)

Baldwin, [Thomas], Introduction to Suggestions on the State of Ireland (Dublin, 1883)

Begg, James, The Proposed Disestablishment of Protestantism in Ireland: Its Bearings on the Religion and Liberties of the Empire (Dublin, 1868)

Birmingham, George, The Lighter Side of Irish Life (London, 1911)

Brown, John, Jacob: A Sermon on Emigration (London, 1865)

Buckley, Michael B., Diary of a Tour in America ed. Kate Buckley (Dublin, c. 1870)

Burke, Thomas Nicholas, Lectures on Faith and Fatherland (Glasgow, [1874])

Byrne, Stephen, Irish Emigration to the United States: What it has been and what it is (New York, 1873)

Cahill, D. W., Argumentative Letter from the Rev. Dr Cahill to the Rt. Hon. Earl of Derby on the General Character of English Statesmen in endeavouring to uproot the Catholic Church - and, as it were, to send the Protestant Bible to Teach all Nations? (Dublin, 1852)

Cahill, D. W., First Letter of Dr Cahill to the Roman Catholics of Ireland (Dublin, 1851)

Cahill, D. W., Fourth Letter from the Rev. D. W. Cahill, D.D. to the Small Tenant Farmers, Tradesmen, and Labouring Classes of Ireland (Dublin, 1860)

Cahill, D. W., Important Letter from the Rev. D.W. Cahill, D.D. to the Small Tenant Farmers, Tradesmen, and Labourers of Ireland (Dublin, 1860)

Carleton, William, Traits and Stories of the Irish Peasantry (3 vols, Dublin, 1834)

Carlyle, Thomas, Reminiscences of my Irish Journey in 1849 ed. James Anthony Froude (New York, 1882)

Clarke, Richard F., My Visit to Distressed Ireland (New York, 1883)

Cogan, Anthony, The Ecclesiastical History of the Diocese of Meath Ancient and Modern (3 vols, Dublin, 1867)

Coulter, Henry, The West of Ireland: its Existing Condition, and Prospects (Dublin, 1862)

Craig, J. Duncan, Real Pictures of Clerical Life in Ireland (London, 1875)

Cullen, The most Rev. Dr [Paul], Pastoral Letter to the Catholic clergy and Laity of the Diocese of Dublin, on the Fast of Lent, 1853 (Dublin, 1853)

Cullen, The most Rev. Dr [Paul], Pastoral Letter to the Catholic Clergy and Laity of the Diocese of Dublin, on the Festival of St Patrick (Dublin, 1853)

Curry, John, All Hallows College, Dublin and its Founder (Dublin, 1900)

Cusack, M. F., The Case of Ireland Stated: A Plea for my People and my Race (Dublin, 1880)

Cusack, M. F., The Nun of Kenmare: an Autobiography (Boston, 1889)

Cusack, M. F., The Speeches and Public Letters of the Liberator (Dublin, 1875)

Dallas, A. B. Incidents in the Life and Ministry of the Rev. Alex R. C. Dallas ... by his Widow (London, 1871)

Dallas, Alexander R. C., Castlekerke (London, 1849) 
Dallas, Alexander R. C., The Story of the Irish Church Missions continued to the year 1869 (London, 1875)

Dill, Edward Marcus, The Mystery Solved: or Ireland's Miseries: The Grand Cause and Cure (Edinburgh, 1852)

Doyle, Martin [Wiliam Hickey], Hints on Emigration to Upper Canada (London, 1831)

Dufferin, The Rt. Hon. Lord, Irish Emigration and the Tenure of Land in Ireland (London, 1867)

Duffy, Charles Gavan (ed.), The Ballad Poetry of Ireland (Dublin, 1869)

Dunne, P[atrick]., The Emigrant's Guide to Queensland and the other Australian Colonies (Dublin, 1863)

Edgar, John, Ireland's Mission Field: A Paper read at the Sixth Annual Conference of the British Organisation, August, 1852 (London, 1852)

Elliott, Robert, Art and Ireland (Dublin, 1904)

England, John, The Works of the Right Rev. John England, First Bishop of Charleston ed. Ignatius Aloysius Reynolds (5 vols, Baltimore, 1849)

Farrell, Joseph, Sermons (Dublin, 1895)

Fitzpatrick, W. J., The Life, Times, and Correspondence of the Right Reverend Dr Doyle, Bishop of Kildare and Leighlin (Dublin, 1890)

Flanagan, John, Ireland: Her Past Glories and Trials, and Probable Future (Dublin, 1882)

Foley, Daniel, A Missionary Tour through the South and West of Ireland, undertaken for the Society (Dublin, 1849)

Foley, Daniel, The People and Institutions of the United States of America: A Summer Vacation Tour (Dublin, 1858)

Forbes, John, Memorandums made in Ireland in the Autumn of 1852 (2 vols, London, 1853)

Gibbons, James Cardinal, A Retrospect of Fifty Years (2 vols, Baltimore, 1916)

Guinan, Joseph, Scenes and Sketches in an Irish Parish, or Priest and People in Doon (Dublin, 1903)

Guinan, Joseph, The Soggarth Aroon (Dublin, 1907)

Hall, Mr and Mrs S. C., Ireland its Scenery Character and History (6 vols, Boston, 1911)

Hancock, W. Neilson, Report on the Supposed Progressive Decline of Irish Prosperity (Dublin, 1863)

Healy, John, History of the Diocese of Meath (2 vols, Dublin, 1908)

Heron, D. Caulfield, Celtic Migrations; A Paper read before the Dublin Statistical Society on Monday, January 19, 1848 (Dublin, 1853)

Hinds, Samuel, Speech delivered at a Meeting of the Society for the Propagation of the Gospel held in Dublin in the Autumn of 1847 (Dublin, 1849)

Hinds, Samuel, The Speech of the Rev Dr Hinds (now Lord Bishop of Norwich) at a Meeting of the Dublin University Branch of the Society for the Propagation of the Gospel in Foreign Parts, 13th December, 1846 (Dublin, 1850) 
Houston, Mrs [Matilda Charlotte], Twenty years in the Wild West, or Life in Connaught (London, 1879)

How, Frederick Douglas, William Conyngham Plunket Fourth Baron Plunket and sixty-first Archbishop of Dublin A memoir (London, 1900)

Hume, Abraham, Results of the Irish Census of 1861, with a Special Reference to the Condition of the Church in Ireland (London, 1864)

Inglis, H. D., A Journey throughout Ireland in the Spring, Summer and Autumn of 1834 (2 vols, London, 1835)

Ingram, John Kells, Considerations on the State of Ireland: Being an address delivered before the Statistical and Social Inquiry Society of Ireland, at the Opening of its Seventeenth Session on Wednesday, November 18, 1863 (Dublin, 1863)

J. K. L., Letters on the State of Ireland; Addressed by J.K.L. to a Friend in England (Dublin, 1825)

Keating, M. I., A Letter to Wilmot Horton, esq. M.P., on Emigration from Ireland (Limerick, c. 1826/27)

Keating, M. I., Emigration, To the Right Honourable Lord Morpeth, M.P. (Limerick, 1836)

Killen, W. D., Memoir of John Edgar (Belfast, 1867)

Killen, W. D., Reminiscences of a Long Life (London, 1901)

Kirwan [Nicholas Murray], Letters to the Right Rev. John Hughes, Roman Catholic Bishop of New York, with an Introduction by John Edgar, D.D. (Belfast, 1851)

Knox, Robert, $A$ Charge delivered in the Primary Visitation of the Dioceses of Down and Connor, and Dromore, in September, 1850 (Dublin, 1850)

Lacy, Thomas, Home Sketches, on both sides of the Channel, being a Diary (London, 1852)

Latimer, William Thomas, A History of the Irish Presbyterians (Belfast, 1902)

Lavelle, Patrick, The Irish Landlord since the Revolution with Notice of Ancient and Modern Land Tenures (Dublin, 1870)

Lawson, James A., The Over-Population Fallacy Considered: A Paper read before the Dublin Statistical Society (Dublin, 1849)

Lee, A. T., 'Some account of the property and statistics of the church' in Essays on the Irish Church by Clergymen of the Established Church in Ireland (London, 1866), pp. 238-42

Lee, Alfred T., Facts Respecting the Present State of the Church in Ireland (Dublin, 1865)

Lewis, George Cornwall, On Local Disturbances in Ireland and on the Irish Church Question (London, 1836)

MacKenzie, David, The Emigrants' Guide or Ten Years' Practical Experience in Australia (London, 1845)

Maclise, D. M., The Dominion of Canada as a Field for Emigrants from the United Kingdom (Ottawa, 1882) 
MacWalter, J. G., The Irish Reformation Movement and its Religious, Social and Political Aspects: Embodying a Compendium and Consecutive History of Ireland's Early Church, its Fall, and every Missionary Organisation which has Laboured up to the Present Time to Restore Pristine Purity with Practical Inferences (Dublin, 1852)

Magee, Hamilton, Circulation of Douay Testaments in Ireland (Dublin, 1855)

Maguire, John Francis, Father Mathew: A Biography (London, 1865)

Maguire, John Francis, The Irish in America (London, 1868)

Malthus, T. R., An Essay on the Principle of Population; Or, A View of its Past and Present Effects on Human Happiness (2 vols, London, 1809)

Mant, Richard, Memoirs of the Right Reverend Richard Mant, Lord Bishop of Down and Connor, and of Dromore (Dublin, 1857)

Martineau, Harriet, Illustrations of Political Economy. Ireland. A Tale (London, 1832)

McCabe, Joseph, The Decay of the Church of Rome (London, 1909)

McCarthy, Michael J. F., Five Years in Ireland, 1895-1900 (Dublin, 1901)

McCarthy, Michael J. F., Priests and People in Ireland (Dublin, 1902)

McCleery, John R., Emigration. Letters on Canada by a Presbyterian Clergyman late returned from that Country (Belfast, 1874)

McDevitt, John, Father Hand: Founder of All Hallows College for the Foreign Missions. The Story of a Great Servant of God (Dublin, 1885)

McDonald, Walter, Reminiscences of a Maynooth Professor, ed. Denis Gwynn (London, 1925)

McDonnell, Michael F. J., Ireland and the Home Rule Movement (Dublin, 1908)

McGee, T. D., A Life of the Rt. Rev. Edward Maginn, Coadjutor Bishop of Derry: With Selections from his Correspondence (New York, 1857)

MacHale, John, A Refutation of the Earl of Shrewsbury's Calumnies against the Catholic Clergy and Bishops of Ireland (Dublin, 1848)

MacHale, John, Letter to the Right Hon. Earl Talbot, Alton Towers (Dublin, 1848)

MacHale, John, The Splendid Oration delivered by the Most Reverend Dr MacHale, Archbishop of Tuam, at the Opening of the Second Session of the National Synod of Ireland, on Thursday, August 29th, 1850 (Dublin, 1850)

McManus, Henry, Sketches of the Irish Highlands: Descriptive, Social, and Religious with Special Reference to the Irish Missions in West Connaught since 1840 (Belfast, 1863)

Mecredy, James, The Reformation in Iar Connacht (Dublin, 1853)

Mill, John Stuart, Principles of Political Economy with Some of their Applications to Social Philosophy (2 vols, London, 1865)

Moore, George, The Untilled Field (London, 1903)

Moran, P. F., The Priests and People of Ireland (Melbourne, 1904)

Moran, Patrick F., Essays on the Origin, Doctrines and Discipline of the Early Irish Church (Dublin, 1864) 
Moran, Patrick F., Irish Saints in Great Britain (Dublin, 1879)

Moran, Patrick Francis, The Pastoral Letters and other Writings of Cardinal Cullen, Archbishop of Dublin (3 vols, Dublin, 1882)

Morgan, James, Recollections of my Life and Times an Autobiography with Selections from his Journal edited by his Son (Belfast, 1874)

Morgan, James, Thoughts on the Famine, its Author, Cause and Remedy (Belfast, 1847)

Moriarty, David, Allocutions to the Clergy and Pastorals, ed. A. Griffin and J. Coffey (Dublin, 1884)

Moriarty, Thomas, Dingle and Ventry Mission (Dublin [?], 1855 [?])

Nicholson, A[senath], Annals of the Famine in Ireland, in 1847, 1848, and 1849 (New York, 1851)

O'Connor, Michael, The Sogarth Aroon, or, the Irish Priest: A lecture (Baltimore, 1869)

O'Hanlon, John, The Irish Emigrant's Guide for the United States (Dublin, 1851)

O'Leary, John, Recollections of Fenians and Fenianism (2 vols, London, 1896)

O'Malley, T[haddeus], An Idea of a Poor Law for Ireland (London, 1837)

O'Neill Daunt, W. J., Personal Recollections of the Late Daniel O'Connell, M.P. (2 vols, London, 1848)

O'Reilly, Bernard, John MacHale, Archbishop of Tuam. His Life, Times and Correspondence (2 vols, New York, 1890)

O'Reilly, Myles, Progress of Catholicity in Ireland in the Nineteenth Century being a paper read before the Catholic Congress of Mechlin, September, 1864 (Dublin, 1865)

O'Riordan, M[ichael], Catholicity and Progress in Ireland (London, 1906)

Olden, Thomas, 'Reading the Irish bible: history of a convert from Romanism' in Charles Bullock (ed.), What Ireland Needs: The Gospel in the Native Tongue (London, c. 1880), pp. 111-18

Olden, Thomas, The Church of Ireland (London, 1892)

Orestes A. Brownson \& Henry Francis Brownson (eds), The Works of Orestes A. Brownson (1884)

Perraud, Adolphe, Ireland under English Rule (Dublin, 1864)

Peyton, Alexander J., The Emigrants' Friend or Hints on Emigration to the United States of America, addressed to the People of Ireland (Cork, 1853)

Plunket, W. C., The Church and the Census in Ireland (Dublin, 1865)

Plunkett, Horace, Ireland in the New Century (London, 1904)

Radcliff, T[homas] (ed.), Authentic Letters from Upper Canada; With an Account of Canadian Field Sports by T. W. McGrath esq. (Dublin, 1833)

Ryan, Richard, Practical Remedies for the Practical Evils of Ireland (Dublin, 1828)

Seddall, Henry, Edward Nangle: Apostle of Achill; A Memoir and a History (London, 1884) 
Seymour, M. H., The Speech of Rev. Mr Seymour at the Sligo Protestant Dinner (Sligo[?], 1830[?])

Shand, Alexander Innes, Letters from the West of Ireland 1884 (Edinburgh, 1885)

Sheehan, Canon [P. A.], Early Essays and Lectures (London, 1906)

Sheehan, P. A., The Graves at Kilmorna (Dublin, 1915)

Simpson, Jonathan, Annals of my Life, Labours and Travels (Belfast, 1895)

Smith, John Talbot, The Chaplain's Sermons (New York, 1896)

Southey, Robert, Essays Moral and Political (2 vols, London, 1832)

Stevenson, Robert Louis, The Amateur Emigrant from the Clyde to Sandy Hook (London, 1895)

Stopford, Edward A., A Reply to Sergeant Shee (Dublin, 1853)

Strain, James K., The Story of a Visit to America: A Lecture (Belfast, 1871)

Thébaud, Augustus, The Irish Race in the Past and the Present (New York, 1873)

Thompson, D. P., A Brief Account of the Rise and Progress of the Change in Religious Opinion now taking place in Dingle and the West of the County of Kerry (London, 1846)

Torrens, Robert, Paper on the Means of Reducing the Poors Rates and of affording Effectual and Permanent Relief to the Labouring Classes (London, 1817)

Townsend, Horatio, Statistical Survey of the County of Cork, with Observations on the Means of Improvement; Drawn up for the Consideration, and by Direction of the Dublin Society (Dublin, 1810)

Tuke, James H., Irish Distress and its Remedies: The Land Question: A Visit to Donegal and Connaught in the Spring of 1880 (London, 1880)

Wakefield, Edward Gibbon (ed.), A View of the Art of Colonisation with Present Reference to the British Empire; Letters between a Statesman and a Colonist (London, 1849)

Whately, Richard, Thoughts on Christian Moral-Instruction: The Necessity, and the Mode of Imparting it. A Charge, delivered to the Clergy of the Dioceses of Dublin, Glendalagh, and Kildare, at the Visitation in June and July, 1854 (Dublin, 1854)

Zwierlein, Frederick J., The Life and Letters of Bishop McQuaid (3 vols, New York, 1925)

\section{Secondary sources}

Books and journal articles

Acheson, Alan, A History of the Church of Ireland, 1691-1996 (Dublin, 1997) Adams, W. F., Ireland and Irish Emigration to the New World from 1815 to the Famine (New York, 1932)

Akenson, Donald Harman, The Irish Diaspora: A Primer (Belfast, 1993) 
Akenson, Donald Harman, Half the World from Home Perspectives on the Irish in New Zealand 1860-1950 (Wellington, 1990)

Akenson, Donald Harman, Small Differences Irish Catholics and Irish Protestants, 1815-1922 An International Perspective (Montreal, 1988)

Akenson, Donald Harman, The Church of Ireland: Ecclesiastical Reform and Revolution, 1800-1885 (London, 1971)

Anbinder, Tyler, 'Lord Palmerston and the Irish Famine emigration' in The Historical Journal, xliv: 2 (June 2001), 441-69

Asch, Beth J. and Courtland Reichmann (eds), Emigration and its Effects on the Sending Country (Santa Monica, 1994)

Bane, Liam, The Bishop in Politics: Loyal Friend, Bitter Foe, Life and Career of John McEvilly (Westport, 1993)

Barber, Shelley (ed.), The Prendergast Letters: Correspondence from Famineera Ireland, 1840-1850 (Amherst, 2006)

Barr, Colin P., "An ambiguous awe": Paul Cullen and the historian' in Dáire Keogh and Albert McDonnell (eds), Cardinal Paul Cullen and his World (Dublin, 2011), pp. 414-34

Barr, Colin, "Imperium in Imperio": Irish episcopal imperialism in the nineteenth century' in English Historical Review, cxxiii:502 (June 2008), $611-50$

Barrett, James R., The Irish Way Becoming American in the Multi-ethnic City (New York, 2012)

Bayly, C. A., The Birth of the Modern World 1780-1914. Global Connections and Comparisons (Oxford, 2003)

Beames, M. R., 'Rural conflict in pre-famine Ireland: peasant assassination in Tipperary 1837-1847' in Past and Present, 81 (Nov. 1978), 75-91

Begadon, Cormac, 'Catholic religious publishing, 1800-91' in James H. Murphy (ed.), The Oxford History of the Irish Book. Vol. IV. The Irish Book in English 1800-91 (Oxford, 2011), pp. 371-8

Belchem, John, Irish Catholic and Scouse: The History of the Liverpool-Irish, 1800-1939 (Liverpool, 2007)

Bielenberg, Andy (ed.), The Irish Diaspora (London, 2000)

Black, R. D. Collison, Economic Thought and the Irish Question 1817-1870 (Cambridge, 1960)

Bowen, Desmond, Paul Cardinal Cullen and the Shaping of Modern Irish Catholicism (Dublin, 1983)

Bowen, Desmond, The Protestant Crusade in Ireland, 1800-70: A Study of Protestant-Catholic Relations between the Act of Union and Disestablishment (Dublin, 1978)

Brown, Stewart J., Providence and Empire: Religion, Politics and Society in the United Kingdom, 1815-1914 (Harlow, 2008)

Brown, Stewart J., The National Churches of England, Ireland, and Scotland 1801-1846 (Oxford, 2001) 
Carey, Hilary M., God's Empire: Religion and Colonialism in the British World, c. 1801-1908 (Cambridge, 2011)

Carey, Hilary M., 'Religion and society' in Deryck Marshall Schreuder and Stuart Ward (eds), Australia's Empire (Oxford, 2008), pp. 186-210

Chambers, Don, 'The Kirk and the Colonies in the early 19th century' in Historical Studies [Australia], xvi:64 (1975), 381-401

Clark, Samuel, Social Origins of the Irish Land War (Princeton, 1979)

Clarke, Brian P., Piety and Nationalism: Lay Voluntary Associations and the Creation of an Irish-Catholic Community in Toronto 1850-1895 (London, 1993)

Coleman, Terry, Passage to America: A History of Emigrants from Great Britain and Ireland to America in the Mid-Nineteenth Century (London, 1972)

Condon, Kevin, The Missionary College of All Hallows, 1842-1891 (Dublin, 1986)

Condon, Kevin, 'United States of America' in Capuchin Annual, 26 (1959), 313-19

Connolly, S. J., 'Cardinal Cullen's other capital: Belfast and the "devotional revolution" in Dáire Keogh and Albert McDonnell (eds), Cardinal Paul Cullen and his World (Dublin, 2011), pp. 289-307

Connolly, S. J., 'Religion, work-discipline and economic attitudes: The case of Ireland' in T. M. Devine and David Dickson (eds), Ireland and Scotland 1600-1850 Parallels and Contrasts in Economic and Social Development (Edinburgh, 1983), pp. 235-46

Connolly, S. J., Priests and People in Pre-Famine Ireland (Dublin, 1982)

Connolly, Sean, Religion and Society in Nineteenth-Century Ireland (Dundalk, 1985)

Corish, Patrick J., Maynooth College, 1795-1995 (Dublin, 1995)

Corish, Patrick J., 'Review: Emigrants and exiles' in Catholic Historical Review, lxxiii:4 (Oct. 1987), 651-2

Corish, Patrick, The Irish Catholic Experience. A Historical Survey (Dublin, 1985)

Cousens, S. H., 'The regional variation in emigration from Ireland between 1821 and 1841' in Transactions of the Institute of British Geographers, 37 (Dec. 1965), 15-30

Daly, Mary E., The New Failure: Population Decline and Independent Ireland, 1922-1973 (London, 2006)

Daly, Mary E., The Spirit of Earnest Inquiry: The Statistical and Social Inquiry Society of Ireland 1847-1997 (Dublin, 1997)

Delaney, Enda, 'The churches and Irish emigration to Britain, 1921-60' in Archivium Hibernicum, lii (1998), 98-114

Dickson, R. J., Ulster Emigration to Colonial America, 1718-1775 (Belfast, 1966) 
Diner, Hasia, Erin's Daughters in America: Irish Immigrant Women in the Nineteenth Century (London, 1983)

Donnelly, Jr, James S., 'Mass evictions and the Great Famine' in Cathal Póirtéir (ed.), The Great Irish Famine (Dublin, 1995), pp. 155-73

Donnelly Jr, James S., 'The Irish Agricultural Depression of 1859-64' in Irish Economic and Social History, iii (1976), 33-54.

Doyle, David Noel, 'Irish Catholicism in the diaspora: the case of the United States' in Brendan Bradshaw and Dáire Keogh (eds), Christianity in Ireland. Revisiting the Story (Dublin, 2002), pp. 231-49

Doyle, David Noel, 'Small differences? The study of the Irish in the United States and Britain' in I.H.S., xxix:113 (May 1994), 114-19

Doyle, David Noel, 'The Irish as urban pioneers in the United States, 1850-1870' in Journal of American Ethnic History, x:1-2 (1990), 36-59

Doyle, David Noel, 'The Irish in Australia and the United States: some comparisons, 1800-1939' in Irish Economic and Social History, xvi (1989), 73-94

Doyle, David Noel, Ireland, Irishmen and Revolutionary America, 1760-1820 (Dublin, 1981)

Dudley Edwards, Owen, 'The Irish priest in North America' in W. S. Sheils and Diana Wood (eds), The Churches, Ireland and the Irish: Papers read at the 1987 Summer Meeting and the 1988 Winter Meeting of the Ecclesiastical History Society (London, 1989), pp. 311-52

Elliott, Bruce S., Irish Migrants in the Canadas. A New Approach (London, 1988)

Elliott, Marianne, The Catholics of Ulster: A History (London, 2001)

Etherington, Norman (ed.), The Oxford History of the British Empire, Companion series: Missions and Empire (Oxford, 2005)

Fanning, Charles, The Irish Voice in America: 250 years of Irish-American Fiction (Lexington, 1999)

Finke, Roger and Rodney Stark, The Churching of America, 1776-1990 (New Brunswick, 1992)

Fitzgerald, Patrick and Lambkin, Brian, Migration in Irish History, 1607-2007 (London, 2008)

Fitzpatrick, David, 'Exporting brotherhood: Orangeism in South Australia' in Enda Delaney and Donald M. MacRaild (eds) Irish Migration, Networks and Ethnic Identities since 1750 (Abingdon, 2007), pp. 129-62

Fitzpatrick, David, 'Ireland and the empire' in Andrew Porter (ed.), The Oxford History of the British Empire, iii: The Nineteenth Century (Oxford, 1999), pp. 495-521

Fitzpatrick, David, Oceans of Consolation: Personal Accounts of Irish Migration to Australia (Cork, 1995)

Fitzpatrick, David, “That beloved country, that nothing else resembles": connotations of Irishness in Irish-Australasian letters, 1841-1915' in I.H.S., xxvii:108 (Nov. 1991), 324-51 
Fitzpatrick, David, 'Emigration, 1871-1921' in W. E. Vaughan (ed.), A New History of Ireland VI: Ireland under the Union II 1870-1921 (Oxford, 1989), pp. 606-52

Fitzpatrick, David, 'Emigration, 1801-70' in W. E. Vaughan (ed.), A New History of Ireland V: Ireland under the Union 1801-1870 (Oxford, 1989), pp. 562-622

Fitzpatrick, David, Irish Emigration 1801-1921 (Dundalk, 1984)

Fitzpatrick, David, 'Irish emigration in the later nineteenth century' in I.H.S., xxii:86 (Sept. 1980), 126-43

Fitzpatrick, David, 'The Disappearance of the Irish Agricultural Labourer, 1841-1912' in Irish Economic and Social History, vii (1980), 66-92

Galloway, Peter, The Cathedrals of Ireland (Belfast, 1992)

Ghosh, R. N., 'Malthus on emigration and colonisation: letters to WilmotHorton' in Economica, xxx:117 (Feb. 1963), 46-62

Gilley, Sheridan, 'Catholicism, Ireland, and the Irish diaspora' in Sheridan Gilley and Brian Stanley (eds), World Christianities c. 1815-1914 (Cambridge, 2006), pp. 250-9

Gilley, Sheridan, 'Catholicism in Ireland' in Hugh McLeod and Werner Ustorf (eds), The Decline of Christendom in Western Europe, 1750-2000 (Cambridge, 2003), pp. 99-112

Gilley, Sheridan, 'The Roman Catholic Church and the nineteenth-century Irish diaspora' in Journal of Ecclesiastical History, xxxv:2 (1984), 188-207

Gray, Peter The Making of the Irish Poor Law, 1815-43 (Manchester, 2007)

Gray, Peter, 'The making of mid-Victorian Ireland? Political economy and the memory of the Great Famine' in Peter Gray (ed.), Victoria's Ireland?: Irishness and Britishness, 1837-1901 (Dublin, 2004), pp. 151-66

Gray, Peter, 'National humiliation and the Great Hunger: fast and famine in 1847' in I.H.S., xxxii:126 (Nov. 2000), 193-216

Gray, Peter, "'Shovelling out your paupers": The British state and Irish famine migration 1846-50' in Patterns of Prejudice, xxxiii:4 (1999), 47-66

Green, E. R .R., 'Ulster emigrants' letters' in E. R. R. Green (ed.), Essays in Scotch-Irish History (London, 1969), pp. 87-103

Green, E. R. R., 'The strange humors that drove the Scotch-Irish to America, 1729' in The William and Mary Quarterly, xii:1 (Jan. 1955), 113-23

Griffin, Patrick, The People with No Name Ireland's Ulster Scots, America's Scots Irish and the Creation of a British Atlantic World 1689-1764 (Oxford, 2001)

Guinnane, Timothy, The Vanishing Irish: Households, Migration and the Rural Economy (Chichester, 1997)

Handlin, Oscar, Boston's Immigrants, 1790-1880: A Study in Acculturation (Cambridge, 1959)

Harper, Marjory, Adventurers and Exiles: The Great Scottish Exodus (London, 2003) 
Harris, Ruth-Ann M., "'Come all you courageously”: Irish women in America write home' in Éire-Ireland, xxxvi:1 (Summer 2001), 166-84

Harris, Ruth-Ann M., "Where the poor man is not crushed down to exalt the aristocrat": Vere Foster's programmes of assisted emigration in the aftermath of the Irish Famine' in Patrick O'Sullivan (ed.), The Irish World Wide, VI: The Meaning of the Famine (London, 1997), pp. 172-94

Harris, Ruth-Ann M., The Nearest Place that wasn't Ireland. Early NineteenthCentury Irish Labor Migration (Ames, 1994)

Harris, Ruth-Ann M. and Donald M. Jacobs (eds), The Search for Missing Friends: Irish Immigrant Advertisements placed in the Boston Pilot (Boston, 1989)

Hazel, M.V., 'First Link: Parnell's American Tour, 1880'in Éire-Ireland, xv:1 (Spring 1980), 6-24

Heimann, Mary, Catholic Devotion in Victorian England (Oxford, 1995)

Hempton, David, Methodism. Empire of the Spirit (London, 2005)

Hempton, David and Myrtle Hill, Evangelical Protestantism in Ulster Society 1740-1890 (London, 1992)

Hempton, David, "For God and Ulster": Evangelical Protestantism and the Home Rule crisis of 1886' in Keith Robbins (ed.), Protestant Evangelicalism: Britain, Ireland, Germany and America, c. 1750-c.1950 Essays in honour of W.K. Ward (Oxford, 1990), pp. 225-54

Hilton, Boyd, A Mad, Bad, and Dangerous People? England 1783-1846 (Oxford, 2006)

Hilton, Boyd, The Age of Atonement. The Influence of Evangelicalism on Social and Economic Thought, 1785-1865 (Oxford, 1986)

Hogan, Edmund M., The Irish Missionary Movement: A Historical Survey 1830-1980 (Dublin, 1990)

Holmes, Andrew, 'The shaping of Irish Presbyterian attitudes to mission, 1790-1840' in Journal of Ecclesiastical History, lvii:4 (Oct. 2006), 711-37

Holmes, Andrew R. 'The Ulster revival of 1859: cause, controversies and consequences' in Journal of Ecclesiastical History, lxiii:3 (July 2012), 488-515

Houston, Cecil J. and William J. Smyth, The Sash Canada Wore: A Historical Geography of the Orange Order in Canada (Toronto, 1980)

Houston, Cecil J. and William J. Smyth, The Orange Order in Nineteenthcentury Ontario: A Study in Institutional Cultural Transfer (Toronto, 1977)

Howe, Stephen, Ireland and Empire. Colonial Legacies in Irish History and Culture (Oxford, 2000)

Hynes, Eugene, Knock: The Virgin's Apparition in Nineteenth-Century Ireland (Cork, 2008)

Hynes, Eugene, 'The great hunger and Irish Catholicism' in Societas, viii (Spring 1978), 137-56

Inglis, Tom, Moral Monopoly. The Catholic Church in Modern Irish Society (Dublin, 1987) 
Jeffrey, Keith (ed.), An Irish Empire?: Aspects of Ireland and the British Empire (Manchester, 1996)

Johnson, J. H., 'The context of migration: The example of Ireland in the nineteenth century' in Transactions of the Institute of British Geographers, $\mathrm{xv}: 3$ (1990), 575-600

Johnson, J. H., 'The Distribution of Irish emigration in the decade before the great famine' in Irish Geography, xxi (1990), 78-87

Keep, G.R.C., 'Some Irish opinion on population and emigration, 1851-1901' in Irish Ecclesiastical Record, ser. 5, lxxxiv (Dec. 1955), 377-86

Keenan, Desmond, The Catholic Church in Nineteenth Century Ireland (Dublin, 1983)

Kennedy, Liam, 'Studies in Irish econometric history' in I.H.S. xxiii:91 (May, 1983), 201-5

Kennedy, Liam, 'The early response of the Irish Catholic clergy to the co-operative movement' in I.H.S., xxi:81 (Mar. 1978), 55-74

Kennedy, Liam, 'The Roman Catholic Church and economic growth in nineteenth century Ireland' in Economic and Social Review, x:1 (Oct. 1978), 45-60

Kennedy, Liam, Kerby A. Miller and Brian Gurrin, 'Minorities, majorities and demographic power: The Protestant and Catholic communities of Tipperary since 1660' in Sean Farrell and Michael De Nie (eds), Power and Popular Culture in Modern Ireland (Dublin, 2010), pp. 67-92

Kennedy, Robert E., The Irish: Emigration, Marriage and Fertility (London, 1973)

Kennedy, Thomas P., A History of Irish Catholicism, V: The Church since Emancipation: 8 Church Building (Dublin, 1970)

Kenny, Kevin, 'The Irish in the empire' in Kevin Kenny (ed.), Ireland and the British Empire (Oxford, 2004), pp. 90-122

Kerr, Donal A., 'A Nation of Beggars'? Priests, People and Politics in Famine Ireland, 1846-1852 (Oxford, 1994)

Kerr, Donal A., Peel, Priests and Politics. Sir Robert Peel's Administration and the Roman Catholic Church in Ireland, 1841-1846 (Oxford, 1982)

Keyes, Michael, Funding the Nation. Money and Nationalist Politics in Nineteenth-century Ireland (Dublin, 2011)

Kiberd, Declan, Inventing Ireland. The Literature of the Modern Nation (London, 1996)

Larkin, Emmet, The Historical Dimensions of Irish Catholicism (Dublin, 1997)

Larkin, Emmet, The Consolidation of the Roman Catholic Church in Ireland, 1860-1870 (Dublin, 1987)

Larkin, Emmet, The Making of the Roman Catholic Church in Ireland, 1850-1860 (Chapel Hill, 1980)

Larkin, Emmet, 'Church, state and nation in modern Ireland' in American Historical Review, lxxx:5 (Dec. 1975), 1244-76 
Larkin, Emmet, The Roman Catholic Church and the Creation of the Modern Irish State 1878-1886 (Dublin, 1975)

Larkin, Emmet, 'The devotional revolution in Ireland, 1850-75' in American Historical Review, lxxvii: 3 (June 1972), 625-52

Larkin, Emmet, 'Economic growth, capital investment and the Roman Catholic Church in nineteenth-century Ireland' in American Historical Review, lxxii:3 (Apr. 1967), 852-84

Lees, Lynn Hollen, Exiles of Erin: Irish Migrants in Victorian London (Manchester, 1979)

Levitt, Peggy, The Transnational Villagers (London, 2001)

Livingstone, David N. and Ronald A. Wells, Ulster-American Religion: Episodes in the History of a Cultural Connection (Notre Dame, 1999)

Luddy, Maria, Women and Philanthropy in Nineteenth-Century Ireland (Cambridge, 1995)

Lynch-Brennan, Margaret, The Irish Bridget: Irish Immigrant Women in Domestic Service in America 1840-1930 (New York, 2009)

Lyne, Gerard, The Lansdowne Estate in Kerry under the Agency of William Steuart Trench 1849-72 (Dublin, 2001)

MacDonagh, Oliver, A Pattern of Government Growth 1800-60: The Passenger Acts and their Enforcement (London, 1961)

MacDonagh, Oliver, 'Emigration during the famine' in R. Dudley Edwards and T. Desmond Williams (eds), The Great Famine Studies in Irish History, 1845-52 (Dublin, 1956), pp. 319-88

MacDonagh, Oliver, 'Emigration and the state, 1833-55: An essay in administrative history' in Transactions of the Royal Historical Society, v (1955), 133-59

MacDonagh, Oliver, 'The Irish catholic clergy and emigration during the great famine' in I.H.S., v:20 (Sept. 1947), 287-302

MacRaild, Donald M., 'The associationalism of the Orange diaspora' in David A. Wilson (ed.), The Orange Order in Canada (Dublin, 2007), pp. 25-41

MacRaild, Donald M., Faith, Fraternity and Fighting: The Orange Order and Irish Migrants in England, c.1850-1920 (Liverpool, 2005)

MacRaild, Donald M., 'Wherever orange is worn: Orangeism and Irish migration in the $19^{\text {th }}$ and early $20^{\text {th }}$ centuries' in The Canadian Journal of Irish Studies, xxviii/xxix:2/1 (2002-2003), 98-117

MacSuibhne, Peadar, Paul Cullen and his Contemporaries (5 vols, Naas, 1965)

Marshall, W. J., 'Irish clergy abroad' in Toby Barnard and W. G. Neely (eds), The Clergy of the Church of Ireland 1000-2000: Messengers, Watchmen and Stewards (Dublin, 2006), pp. 259-78

Matthew, H. C. G. and Brian Harrison (eds) Oxford Dictionary of National Biography (Oxford, 2004)

McAvoy, Thomas T., 'Orestes A. Brownson and John Hughes in 1860' in The Review of Politics, xxiv:1 (Jan. 1962), 19-47 
McBride, Lawrence W., 'The Reynolds letters: sources for understanding the Irish emigrant experience in America and England, 1865-1934' in Charles Fanning (ed.), New Perspectives on the Irish Diaspora (Carbondale, 2000), pp. 131-51

McCaffrey, Lawrence J., The Irish Catholic Diaspora in America (Washington, 1997)

McCaffrey, Lawrence J., 'The Catholic and urban profile of Irish America' in Irish Review, 14 (1993), 1-9.

McCaffrey, Lawrence J., 'Irish textures in American Catholicism' in The Catholic Historical Review, lxxviii:1 (Jan. 1992), 1-18

McCaffrey, Lawrence J., Irish Nationalism and the American Contribution (New York, 1976)

McCarthy, Angela, Personal Narratives of Irish and Scottish Migration, 1921-65. 'For Spirit and Adventure' (Manchester, 2007)

McGrath, Thomas, Religious Renewal and Reform in the Pastoral Ministry of Bishop James Doyle of Kildare and Leighlin, 1786-1834 (Dublin, 1999)

McGrath, Thomas G., 'The tridentine evolution of modern Irish Catholicism, 1563-1962. A re-examination of the 'devotional revolution' thesis' in Recusant History, xx:4 (Oct. 1991), 512-23

McRaild, Donald M., Irish Migrants in Modern Britain, 1750-1922 (London, 1999)

Merwick, Donna, Boston Priests, 1848-1910 A Study of Social and Intellectual Change (Cambridge, Mass., 1973)

Miller, David W., 'Religious commotions in the Scottish diaspora: a transatlantic perspective on 'evangelicalism' in a mainline denomination' in David A. Wilson and Mark G. Spencer (eds), Ulster Presbyterians in the Atlantic World: Religion, Politics and Identity (Dublin, 2006), pp. 22-38

Miller, David W., 'Landscape and Religious Practice: A Study of Mass Attendance in Pre-Famine Ireland' in Éire-Ireland, xl:1\&2 (Spring/Summer 2005), 90-106

Miller, David W., 'Irish Catholicism and the Great Famine' in Journal of Social History, ix (Sep. 1975), 81-98

Miller, Kerby A., Ireland and Irish America: Culture, Class, and Transatlantic migration (Dublin, 2008)

Miller, Kerby A., "'Revenge for Skibbereen": Irish emigration and the meaning of the Great Famine' in Kerby A. Miller, Ireland and Irish America: Culture, Class and Transatlantic Migration (Dublin, 2008), pp. 66-78

Miller, Kerby A., 'Revd James MacSparran's America dissected (1753): eighteenth-century emigration and constructions of "Irishness" in History Ireland, xi:4 (Winter 2003), 17-22

Miller, Kerby A., 'The lost world of Andrew Johnston: Sectarianism, social conflict, and cultural change in southern Ireland during the pre-Famine 
era' in James S. Donnelly, Jr and Kerby A. Miller (eds), Irish Popular Culture, 1650-1850 (Dublin, 1998), pp. 222-41

Miller, Kerby A., 'Emigration, ideology and identity in post-Famine Ireland' in Studies: An Irish Quarterly, lxxv:300 (Winter, 1986), 515-27

Miller, Kerby A., Emigrants and Exiles: Ireland and the Irish Exodus to North America (Oxford, 1985)

Miller, Kerby A., Arnold Schrier, Bruce Bolling and David N. Doyle, Irish Immigrants in the Land of Canaan: Letters and Memoirs from Colonial and Revolutionary America, 1675-1815 (Oxford, 2003)

Moffitt, Miriam, The Society for Irish Church Missions to the Roman Catholics, 1849-1950 (Manchester, 2010)

Moffitt, Miriam, Soupers and Jumpers: The Protestant Missions in Connemara (Dublin, 2008)

Mokyr, Joel, Why Ireland Starved. A Quantitative and Analytical History of the Irish Economy, 1800-1850 (London, 1983)

Mokyr, Joel and Cormac Ó Gráda, 'Emigration and poverty in pre-famine Ireland' in Explorations in Economic History, xix:3 (1982), 360-84

Moran, Gerard, Sending out Ireland's Poor. Assisted Emigration to North America in the Nineteenth Century (Dublin, 2004)

Moran, Gerard, "In search of the promised land": The Connemara colonization scheme to Minnesota, 1880' in Éire-Ireland, xxxi:3-4 (1996), 130-49

Murphy, Ignatius, The Diocese of Killaloe 1850-1914 (Dublin, 1995)

Murphy, Ignatius, The Diocese of Killaloe 1800-1850 (Dublin, 1992)

Murphy, Ignatius, 'Building a church in 19th century Ireland' in The Other Clare, ii (Apr. 1978), 20-5

Murphy, James H., 'The role of Vincentian parish missions in the 'Irish counter-reformation' of the mid nineteenth century' in I.H.S., xxiv:94 (Nov. 1984), 152-71

Murphy, Maureen, 'Charlotte Grace O'Brien and the Mission of Our Lady of the Rosary for the Protection of Irish Immigrant Girls' in Mid-America, lxxiv:3 (1992), 253-70

Neville, Grace, "She never then after that forgot him": Irishwomen and emigration to the United States in Irish Folklore' in Mid-America, lxxiv:3 (Oct. 1992), 271-89

Newman, Jeremiah, 'Emigration and the faith: the principles' in Christus Rex, x:4 (Oct. 1956), 315-34

Ní Ghiobúin, Mealla, Dugort, Achill Island. 1831-1861. The Rise and Fall of a Missionary Community (Dublin, 2001)

Nockles, Peter, 'Church or Protestant sect? The Church of Ireland, high churchmanship, and the Oxford movement, 1822-1869' in The Historical Journal, xli:2 (June 1998), 457-93

Nolan, Janet, Ourselves Alone: Emigration from Ireland 1885-1920 (Lexington, 1989) 
Norman, E. R., The Catholic Church and Ireland in the Age of Rebellion 1859-1873 (New York, 1965)

O'Connell, Maurice R., The Correspondence of Daniel O'Connell (8 vols, Dublin, 1972-1980)

O'Connor, Daniel and others, Three centuries of Mission: the United Society for the Propagation of the Gospel 1701-2000 (London, 2000)

O'Farrell, Patrick, Vanished kingdoms: Irish in Australia and New Zealand A Personal Excursion (Sydney, 1990)

O'Farrell, Patrick, The Irish in Australia (Kensington, 1986)

O'Farrell, Patrick, Letters from Irish Australia, 1825-1929 (Belfast, 1984)

O'Farrell, Patrick, Ireland's English Question Anglo-Irish Relations 1534-1970 (London, 1971)

O'Ferrall, Fergus, “The only lever..."? The Catholic priest in Irish politics, 1823-29' in Studies: An Irish Quarterly Review, lxx (Winter 1981), 308-24

Ó Gráda, Cormac, Ireland: A New Economic History 1780-1939 (Oxford, 1994)

Ó Gráda, Cormac, 'Irish emigration to the United States in the nineteenth century' in David Noel Doyle and Owen Dudley Edwards (eds), America and Ireland, 1776-1976: The American Identity and the Irish Connection (London, 1980), pp. 93-103

Ó Gráda, Cormac, 'A note on nineteenth-century Irish emigration statistics' in Population Studies, xxix:1 (Mar. 1975), 143-9

Ó’Mearáin, L., 'Estate agents in Farney: Trench \& Mitchell' in Clogher Record, $\mathrm{x}(1981), 405-13$

O’Neill, Timothy P., 'Poverty in Ireland, $1815-45$ ' in Folk Life, xi (1974), 22-33

O'Neill, Timothy P., 'The Catholic church and relief of the poor, 1815-45' in Archivium Hibernicum, xxxi (1973), 132-45

O'Rourke, Kevin, 'Emigration and living standards in Ireland since the famine' in Journal of Population Economics, viii:4 (1995), 407-21

O'Shea, James, Priests, Politics and Society in Post-Famine Ireland: A Study of County Tipperary 1850-1891 (Dublin, 1983)

O'Sullivan, Patrick (ed.), The Irish World Wide: History, Heritage, Identity, 4. Irish Women and Irish Migration (Leicester, 1995)

O'Sullivan, Patrick, 'Introduction' in Patrick O'Sullivan (ed.), The Irish Worldwide. History, Heritage, Identity. Vol. 2 The Irish in the New Communities (Leicester, 1992), pp. 1-25

Ó Tuathaigh, Gearóid, 'Language, ideology and national identity' in Joe Cleary and Claire Connolly (eds), The Cambridge Companion to Modern Irish Culture (Cambridge, 2005), pp. 42-58

Pascoe, C. F., Two Hundred Years of the S.P.G.: An Historical Account of the Society for the Propagation of the Gospel in Foreign Parts 1701-1900 Vol. II (London, 1901) 
Porter, Andrew, Religion Versus Empire? British Protestant Missionaries and Overseas Expansion, 1700-1914 (Manchester, 2004)

Porter, Andrew, 'Religion, missionary enthusiasm, and empire' in Andrew Porter (ed.), The Oxford History of the British Empire, iii: The Nineteenth Century (Oxford, 1999), pp. 222-46

Proudfoot, Lindsay, 'Place and Presbyterian discourse in colonial Australia' in Lindsay J. Proudfoot and Michael M. Roche (eds), (Dis)Placing Empire: Renegotiating British Colonial Geographies (Aldershot, 2005), pp. 61-80

Proudfoot, Lindsay and Dianne Hall, 'Points of departure: remittance emigration from south-west Ulster to New South Wales in the later nineteenth century' in International Review of Social History, 1:2 (Aug. 2005), 241-77

Rafferty, Oliver P., 'The Catholic Church, Ireland and the British Empire 1800-1921' in Historical Research, lxxxiv:224 (May 2011), 288-309

Rafferty, Oliver P., Catholicism in Ulster 1603-1983 (Dublin, 1994)

Rashid, Salim, 'Richard Whately and Christian political economy at Oxford and Dublin' in Journal of the History of Ideas, xxxviii:1 (Jan. - Mar. 1977), 147-55

Rees, Jim, A Farewell to Famine (Arklow, 1994)

Scally, Robert James, The End of Hidden Ireland: Rebellion, Famine, and Emigration (Oxford, 1996)

Schrier, Arnold, Ireland and the American Emigration, 1850-1900 (Minnesota, 1958)

Scott, Franklin D., 'The study of the effects of emigration' in Scandinavian Economic History Review, viii:2 (1960), 161-74

Shaughnessy, Gerald, Has the Immigrant kept the Faith? A Study of Immigration and Catholic Growth in the United States 1790-1920 (New York, 1925)

Smyth, Alfred P., Faith, Famine and Fatherland in the Irish Midlands. Perceptions of a Priest and Historian. Anthony Cogan, 1826-1872 (Dublin, 1992)

Stanley, Brian, The Bible and the Flag. Protestant Missions and British Imperialism in the Nineteenth and Twentieth Centuries (Leicester, 1990)

Steele, E. D., 'Cardinal Cullen and Irish nationality' in I.H.S., xix:75 (Mar. 1975), 239-60.

Stortz, Gerald J., 'Archbishop Lynch's The Evils of Wholesale and Improvident Emigration from Ireland (1864)' in Eire-Ireland, xviii:2 (Summer 1983), 6-16

Strong, Rowan, Anglicanism and the British Empire, c. 1700-1850 (Oxford, 2007)

Swords, Liam, A Dominant Church: The Diocese of Achonry, 1818-1960 (Blackrock, 2003)

Taggart, Norman W., The Irish in World Methodism 1760-1900 (London, 1986) Tanner, Marcus, Ireland's Holy Wars: The Struggle for a Nation's Soul, 1500-2000 (Dublin, 1999)

Taylor, Lawrence J., Occasions of Faith: An Anthropology of Irish Catholics (Dublin, 1995) 
Thompson, H. P., Into all Lands: The History of the Society for the Propagation of the Gospel in Foreign Parts 1701-1950 (London, 1951)

Thorne, Susan, Congregational Missions and the Making of an Imperial Culture in Nineteenth-Century England (Stanford, 1999)

Vaughan, W. E. and A. J. Fitzpatrick (eds), Irish Historical Statistics. Population, 1821-1971 (Dublin, 1978)

Whelan, Irene, The Bible War in Ireland: The 'Second Reformation' and the Polarization of Protestant-Catholic Relations, 1800-1840 (Dublin, 2005)

Whelan, Irene, 'Edward Nangle and the Achill mission, 1834-1852' in Raymond Gillespie and Gerard Moran (eds), 'A Various Country' Essays in Mayo History 1500-1900 (Westport, 1987), pp. 113-34

Whyte, J. H., 'The influence of the Catholic clergy on elections in nineteenthcentury Ireland' in English Historical Review, lxxv:295 (Apr. 1960), 239-59

Yates, Nigel, The Religious Condition of Ireland 1770-1850 (Oxford, 2006)

\section{Unpublished theses}

Addley, W. P., 'A study of the birth and development of the overseas missions of the Presbyterian church in Ireland up to 1910' (PhD thesis, QUB, 1994)

McCain, Mary Donoghue, 'Father Thomas N. Burke, O.P.: The Sacredness And Eloquence Of The Word' (Ph.D. thesis, University of Chicago, 2012)

McKinney, Amy, 'Joseph Dixon and the Archdiocese of Armagh, 1852-66' (PhD thesis, QUB, 2008)

McLaughlin, Eoin 'Microfinance institutions in nineteenth century Ireland' (PhD thesis, NUI Maynooth, 2009)

McLoughlin, Dympna, 'Information flows and Irish emigration: The image of America in Ireland 1820-1870. A study of parliamentary papers, newspapers, pamphlets and emigrants' lore' (MA dissertation, St Patrick's College, Maynooth, 1983)

Lectures/talks

Comerford, Patrick, 'Success or failure?: Church of Ireland overseas missions', based on a lecture given at N.U.I. Maynooth, 3 March, 2008. Available at http://revpatrickcomerford.blogspot.com/2008/03/success-or-failurechurch-of-ireland.html, accessed 17 Feb. 2008

O’Neill, Ciaran, 'Colonized twice?: Rethinking the relationship between Catholics and empire in the nineteenth century', Paper before Catholic Historical Society of Ireland Conference, NUI Maynooth, 3 Nov. 2012

\section{Internet sources}

David, A. E., Handbooks of English Church Expansion: Australia (London, 1908). Available at Project Canterbury, http://anglicanhistory.org/aus/ aedavid1908/04.html, accessed 10 Apr. 2009

McMahon, Andrew 'The diocese of Dromore, past and present'. Available at 
www.lisburn.com/books/dromore-diocese/parish-seapatrick.html, accessed 20 Jan. 2008

Mercier, Jerome, Father Pat: A Hero of the Far West (Gloucester, 1909). Available at Project Canterbury, http://anglicanhistory.org/canada/fatherpat. html, accessed 10 Apr. 2009

Symonds, Edward, The Story of the Australian Church (London, 1898). Available at Project Canterbury, http://anglicanhistory.org/aus/symonds1898/, accessed 10 Apr. 2009

\section{Television series}

The Irish Empire [TV series], BBC (2000) 


\section{Index}

Akenson, Donald 3, 14n.11, 141n.139, 209

All Hallows College 93, 185, 239 alumni 121-2

comparisons with Maynooth $120-1,124,129-30$

conditions at $120-1$

foundation of 103-6

funding of 117-20

politics of $124-8$

quality of priests $128-30$

statistics of priests sent by

142n. 144

American Friendly Association for Irish Emigrants 73

anti-Catholicism 110, 154-6, 164-5, 168, 198, 204, 221n.52, 235

see also Know-Nothings

anti-clericalism 231n.188, 235-6

Antrim 94, 96, 139n.101, 185

Armagh 100, 108, 230n.177, 231n.182

assisted emigration 6, 25, 28, 31, 49

clerical schemes 77-80, 171, 237

landlord schemes 41-2

other private schemes $47-8$

Poor Law schemes 38

state schemes $26,30,47-8,65,66$

Association for the Propagation of the

Faith 93, 103, 118, 119

Australia see New South Wales,

Queensland, Victoria
Baltimore 99, 184, 206

Barr, Colin 200, 203, 217n.6

Baptists 4, 94, 95, 96

Belfast 47, 71, 73, 94, 96, 108, 109, $110,112,116,159,164,194$, 209

Beresford, Archbishop John George (Armagh) 29

Bicheno, J. E. 29

Boston 206, 211

British empire 9, 99, 106, 110, 128, 140n.119, 181, 182, 186, 187, $188,189,190,240$

British North America see Canada

Brown, Rev. John 38, 190, 241

Browne, Bishop George (Galway, Elphin) 41, 210

Brownson, Orestes 129, 183, 202

Buckley, Rev. Michael 71, 97, 98, 215, 232n.196

Bugler, Rev. Michael 79

Burke, Rev. Thomas Nicholas 184, 187

Byrne, Rev. Stephen 76

Cahill, Rev. Daniel William 43, 67, 75, $76,171,188$

Canada 14n.11, 26, 39, 40, 48, 64, 65, $71,76,94,96,97,107,108,110$, $113,115,116,122,127,130$, 140n.119, 197

Cantwell, Bishop John (Meath) 103 
Carlow 77, 89n.122

Carlow College (St Patrick's) 102, 130

Catholic Church

critique of emigration 42,48

demographic change and 3, 168, 198-9

devotional revolution $8-9,18 \mathrm{n} .38$, $170,205-8,237-8$

economic interests of 170,172 ,

210, 214-15

emigration policy of $10,38,73-5$

hierarchy $12,39-40,45,48,49,74$,

$93,102-3,105,159,198,199-$

200, 204, 224n.104, 229n.161,

234,237

internal migration and 49

Irish America and 92-5

responses to Protestant missionary activity 110-11, 163, 205

'spiritual empire' and 9, 181-8, 190-205

Synod of Thurles 210

Catholic Defence Association 151, 163-4

Catholic Emancipation 37, 154, 208

Catholic Emigration Society 38

Catholic University 163, 165, 187, 200, 210, 226n.119

Catholic Young Men's Society 5, 125

Cavan 42, 66, 154, 158, 230n.181

censuses

$18313-4$

1851150

1861 168-9, 172, 179n.124, 240 $19013-4,240$

Chalmers, Rev. Thomas 28

Chisholm, Caroline 69, 70, 84n.55

Christian Brothers 118, 126, 192

Church of Ireland

1861 census and 168-9, 240

administrative reform $8,46,97$,

$169,190,243 \mathrm{n} .15$

clergy income 92-3

emigration policy of 71-3

empire and 189-90, 240

home missions and 154-61, 167 church-building 113, 208-9, 210-12, $213,224 n .104$

Clare 65, 115, 150, 152, 163, 211

Colonial Church and School Society

(Colonial and Continental

Church Society) 93, 109, 110, 117,123

Condon, Kevin 106, 118, 127, 129

Congested Districts Board 49, 80

Connolly, James 182

Cooke, Rev, Henry 73, 94, 106

Cork 27, 34, 37, 39, 62, 68, 69, 97, 102, 104, 171, 176n.81, 187, 211, $231 \mathrm{n} .182,232 \mathrm{n} .196$

counter-reformation 163, 205, 240

Croke, Archbishop Thomas (Cashel) 203, 223n.86

Crotty, Bishop Bartholomew (Cloyne and Ross) 102, 105, 120-1

Cullen, Cardinal Paul (Armagh, Dublin) 8, 71, 73, 77, 78, 104-5, $118,125,126,127,129,152$, $163,165,169,171,182,184$, $188,191,196,198,199-202$, 203-5, 210, 211, 216, 226n.127, 227n. 12

Curry, Rev. John 126-7, 129

Cusack, Sister Mary Frances ('Nun of Kenmare') 12, 67, 87n.89, 152-3

Dallas, Rev. Alexander 156, 166, 167

Davitt, Michael 49, 203, 226n. 125

Derry (Londonderry) 36, 38, 40, 91, 96, 107, 139n.101, 161, 195, 232n.194, 241

Devine, Rev. Pius (C. P.) 215, 232n.197, 232n.198

diaspora 1, 181, 183, 189

fundraising tours amongst 209, 210-13

lapsed religion amongst 6, 62-3, $93,99,109,167,182$

religious publishing amongst 207-8

Dill, Rev. Edward Marcus 159, 165 
Dineen, Rev. P. S. 186

Dixon, Archbishop Joseph (Armagh) 214

Donegal 29, 34, 35, 43, 46, 64, 211, 230n.181, 231n.182

Donnelly, Bishop James (Clogher) 95, 165,211

Donnelly, James S. 41

Doran, Rev. John 78, 89n.122

Down 33, 35, 37, 78, 96, 98

Doyle, Bishop James Warren (Kildare and Leighlin) $30,37,38,66,68$, 154,206

Dublin 8, 26, 27, 29, 39, 45, 48, 72, 78, 93, 97, 102, 103, 104, 108, 109, $118,154,161,190,206,207$, 208, 212, 213, 234

Dublin School see Statistical and Social Inquiry Society of Ireland

Dufferin and Ava, Marquis of (Frederick Hamilton-TempleBlackwood) 45-6

Duffy, Charles Gavan 125, 213

Duggan, Bishop Patrick (Clonfert) 49

Dunne, Rev. Patrick 79

Durcan, Bishop Patrick (Achonry) 196, 200, 224n.104

Edgar, Rev. John 156, 157, 164, 165 Edwards, Owen Dudley 79, 124, 128 emigration

clerical advice on 75-7, 87n.98, 96, 237,241

clerical condemnation of 6,10 , $35-8,46,62-5,91,153$

economists and 23-4, 25-6, 27-8, 30, 43-5, 80, 195

effects on clerical income of 79 , 151-3

landlords and 25, 29, 31, 37, 38, 40-2, 43-6, 50, 65, 83n.43, 186, $194,198,201,239$

parliamentary inquiries into $26-7$, 28-38, 39, 40, 49, 55n.86, 66, $68,77,241$ pastoral letters on $43,45,48,171$, 184, 197, 199, 201, 204-5 women and $67,69,74,79,84$ n.55, 234

Emigrants' Protection Society 73

Emigrants' Spiritual Aid Fund 72

England, Bishop John (Charleston) $62,93,99,102,103,201,235$

Faber, Rev. Frederick William (C. O.) 186, 202

Feeny, Bishop Thomas (Killala) 56n.99

Fenians (Irish Republican Brotherhood) 47, 125-7, 132, 171, 188, 196-9, 201, 203, 216, 224n.100, 224n.104

Fermanagh 54n.75, 62, 66 Fitzpatrick, David 6, 7, 23, 42

Foley, Rev. Daniel 167, 178n.114

Foley, Rev. John 104, 129, 138n.82

Foran, Bishop Nicholas (Waterford and Lismore) 104

Foster, Vere 69, 84n.55

Franciscans 159, 202, 212

French Catholicism 70, 118, 191, 193, $194,202,226 n .120$

fundraising $63,79,104,107,117$, 163, 209-12, 214, 229n.161, 233 n.203

Galway 40, 44, 45, 48, 82n.18, 156, $210,212,231 n .193$

Gibbons, Cardinal James (Baltimore) 184

Gilley, Sheridan 182, 191

Gillooly, Bishop Laurence (Elphin) 200

Godley, John Robert 40, 42

Great Famine 2, 3, 6, 8, 39, 41, 42, 46, $47,50,63,77,78,109,118,119$, 120, 149-53, 155-6, 160, 172, 193, 194-5, 196, 201, 204, 205, 222n.75, 234, 237

Guinan, Canon Joseph 64 
Hancock, W. Neilson 44, 45, 46

Hand, Rev. John 103-5, 118, 119, 121, 129,133

Hannay, Canon James (George Birmingham) 66, 80n.1

Harris, Ruth-Ann 125, 128

Healy, Rev. John 240

Hearne, Rev. Daniel 211, 229n.166

Heron, Denis Caulfield 44

Hibernian Church Missionary Society 93, 108, 109, 116

Hickey, Rev. William (Martin Doyle) 28, 32, 76, 97, 241

Higgins, Bishop William (Ardagh and Clonmacnoise) 210

Hore, Rev. Thomas 77

Horton, Robert Wilmot 26-8, 30, 38, 47

Howley, Rev. Richard 124-7

Hughes, Archbishop John (New York) 76, 88n.106, 211

Hynes, Eugene 170

inter-church rivalry 78, 109-11 see also Sectarianism

Irish Church Missions 154, 156, 163, 167

Irish College Paris 78

Irish College Rome 11, 43, 77, 104, 192, 195, 201-2

Irish Society for Promoting the Education of the Native Irish through the Medium of the their Own Language 154, 158, $160,161,167,178$ n.114

Islands and Coasts Society 154, 164, 166

Jebb, Bishop John (Limerick, Ardfert and Aghadoe) 27

Keane, Bishop William (Cloyne) 197 Keating, Rev. Michael 28, 38, 45-6, $55 n .85$

Keenan, Desmond 208

Kerr, Donal 154
Kerry 35, 41, 45, 70, 125, 160, 161-2, 211

Kickham, Charles 196, 201, 204

Kildare 30, 108, 231n.183

Kilkenny 212

Killen, Rev. W. D. 241

Kirby, Rev. Tobias 43, 104-5, 152, 192, 197, 198, 201, 202, 212, 215, $231 n .182$

Know-Nothings 63 see also anti-Catholicism

Knox, Bishop Robert (Down and Connor and Dromore) 73, 108, 116

land 4, 24, 25, 39, 43, 45, 46, 47, 75, 78, 152n.119, 196, 198, 203 evictions from $41-2$ reclamation of $28,42,49$

Lang, Rev. John Dunmore 94, 107

Laois see Queen's County

Larkin, Emmet 8-9, 169, 198, 201, 205, 208, 226n. 127

Leahy, Archbishop Patrick (Cashel) $127,153,171,198-9,204,241$

Leitrim 40, 150, 230n.181, 231n.182

Leo XIII, Pope 202, 203

Limerick 5, 27, 30, 36, 37, 39, 40-1, $66,84,140,150,156,215$, 230n. 181

Limerick Emigrants' Friend Society 38,45

Liverpool 69, 72, 73, 79, 201, 204

Logue, Cardinal Michael (Raphoe, Armagh) 49, 214

London 26, 44, 92, 108-9, 117, 158, $205,206,210$

Longford 68, 160, 231n.188

Louth 35,210

Lynch, Archbishop John Joseph (Toronto) 63, 196-7, 201, 218n.12, 224n.90, 226n.127, 235

Magee, Rev. Hamilton 164, 166

Maginn Bishop Edward (Derry) 40 
Maher, Rev. James 77-8, 171, 193

Malthus, Rev. Thomas 24, 25, 26, 28

Malthusianism 24-5, 27, 28, 42, 162

Manchester 211

Manning, Cardinal Henry Edward (Westminster) 202

Martineau, Harriet 30, 152

McCarthy, Michael J. F. 231n.188, 235, 242n.5

McClure, Rev. William 107, 110, 113-15, 123, 130, 131

McCool, Rev. Patrick 74

McCrea, Rev. J. B. 29

McCulloch, J. R. 25

MacDonagh, Oliver 6, 10, 65, 69, 73, 77

McDonald, Rev. Walter 236

McEvilly, Archbishop John (Galway, Tuam) 45, 48

McGennis, Bishop Edward (Kilmore) 153

McGettigan, Archbishop Daniel (Armagh) 172

MacHale, Archbishop John (Tuam) 40, 45, 155, 158, 193, 195, 199-200, 201, 222n.75

MacKenzie, Rev. John 76, 132

Mathew, Rev. Theobald 38, 65, 68, $183,211,218 \mathrm{n} .13$

Mayo 67, 151, 156, 159, 230n.181

Meath 28, 103, 211, 240

Medieval Christianity 99-100, 183-4, 189

Merwick, Donna 124

Methodists 4-5, 37, 64, 83n.35, 87 n. $98,94,96,154,221 n .50$, 229n. 158

Miley, Rev. John 78, 171

Miller, Kerby 2, 3, 6-7, 62, 91, 181

missionary clergy difficulties encountered in the field $121-4,127$

difficulty recruiting 130-2

faults of $93,96-7,124,128-30$

funding of 92, 105, 111-20

training of 104, 106, 125-6
Mission of Our Lady of the Rosary for the Protection of Immigrant Irish Girls 74, 223n.86

Mitchel, John 222n.75

Mokyr, Joel 35

Monaghan 106, 133n.6

Moore, George 149, 171-2

Moran, Cardinal Patrick F. (Ossory, Sydney) 126, 199, 201, 214

Morgan, Rev. James 195, 209

Moriarty, Bishop David (Kerry) 45, 77, 103, 118-19, 120, 125, 127, 128, 129, 144n.191, 144n.193, 200

Moriarty, Rev. Thomas 160

Mullen, Rev. Robert 63-4, 163-5, 167, 169, 177n.100, 204, 211, 235, 238

Murphy, Bishop John (Cork) 69, 102 Murray, Archbishop Daniel (Dublin) 39, 66, 72, 89n.122, 103, 105

Nangle, Rev. Edward 155-6, 158, 159, 163

National Association (of Ireland) 43, 198

Neville, Grace 215

Newman, Cardinal John Henry 185, 202

New South Wales 66, 94, 102, 121, $134 n .20$

New York 67, 69, 72, 73, 74, 76, 78, 87n.89, 94, 95, 97, 127, 206-7, 211,213

New Zealand 3, 46, 100, 108, 115, 123

North American Colonial Association of Ireland 38-9

Nugent, Rev. James 7-80

O’Brien, Charlotte Grace 69, 74

O’Brien, Rev. Richard Baptist 86n.74, 118, 125, 127, 185

O’Brien, William Smith 38, 55n.84

O'Connell, Rev. Andrew 195

O’Connell, Daniel 55n.86, 93, 193, 201

O'Connor, Bishop Michael (Pittsburgh) 134n.20, 187, 219n.30 
O'Connor, Rev. Bartholomew (Batt) 211, 232n.194

O'Farrell, Patrick 101, 185, 217n.7

Offaly 154, 212

O'Hanlon, Rev. John 76

O’Leary, John 196, 199-201, 203

Orange Order 5, 29, 43, 66, 71, 189

O'Riordan, Monsignor Michael 195, 214, 235

O'Sullivan, Rev. Eugene 162, 170

O'Sullivan, Archdeacon John 41, 161, 170, 179n.131

passage

difficulties during 35, 63 69-72, 237

payment of $34,35,41,42,47,65$, $68,79,112,117,161-2,237$

Passionists 212, 215

Perraud, Cardinal Adolphe 70, 194, 202, 203

Peter Robinson emigration scheme 26-8, 30, 65

Peyton, Rev. Alexander 75, 211

Pius IX, Pope 202

Plunkett, Sir Horace 213, 231n.189, 235

Poor Inquiry 30, 31-8, 172

findings ignored 38

Porter, Rev. George (S. J.) 186, 202

poverty $28,29,31,34,44,49,184,192$, 195, 196, 201

Presbyterian Church

1859 Revival 168, 205, 241

Colonial Mission of 93, 106-7,

$112-16,130-2$

emigration policy of 72-3

General Assembly of 46, 107, 114,

$115,131,156,166,209$

Home Mission of 107, 115, 156, 166,168

Propaganda Fide, Sacra Congregatio de 104, 105, 203

Proselytism 70-1, 184, 191, 205, 219n.30, 236

see also Second Reformation
Protestant Colonisation Society 29,

$37,43,49,58 \mathrm{n} .124,155$

Protestant imperialism 188-90

'Protestant interest' 2, 25, 149

Providence

Catholics and 100, 183-8, 192205, 218n.86, 238

evangelicals and 100, 156-7, 164$7,188-90,191-2,194-5,240$

Quakers 4, 14n.17, 47

Quebec 70, 72, 122, 196

Queen's County 33

Queensland 79, 110, 113, 130, 131, 132

Queensland Emigration Society 79

Quinn, Bishop James (Brisbane) 79, 110

Quinn, Rev. William 78

Redmond, Rev. James 43, 153

remittances $66,67,68,84 \mathrm{n} .51,213$, 233n.204, 237, 241

Ricardo, David 27

Roscommon 41, 47, 67, 230n.181

Ryan, Rev. Richard 28, 29

San Francisco 236

Schrier, Arnold 5, 6, 68, 153

Scottish emigration 16n.32, 51n.19, 57n.109, 179n.122

Scully, Rev. Edmund 63

Second Reformation 9, 149, 154-68, 240

sectarianism 4, 30, 36-7, 109-11, 153, 160

Seymour, Rev. Michael 29, 30

Sheehan, Canon Patrick 187, 194, 195-6, 204, 209

Shinnors, Rev. M. F. (O. M. I.) 234-6

Simpson, Rev. Jonathan 70, 209

Slattery, Archbishop Michael (Cashel) 102

Sligo 36, 41, 90n.129, 196

Smith, Rev. John Talbot 234, 236, 238

Society for the Propagation of the 
Gospel in Foreign Parts 72, 92-3, 103, 107-8, 109, 110, 116-17, 122, 134n.14, 140n.119, 142n.143

Souperism 156-7, 160, 162, 169, 170

Statistical and Social Inquiry Society of Ireland 44, 45, 58n.128

St Patrick's Day 195, 196, 202, 226n.119

Strain, Rev. James 71

Tenant League 151-2

Thébaud, Abbé Auguste (S. J.) 184-5, 187,202

theodicy 11, 192

Tipperary 36, 64, 94, 150, 154, 160, 212,230 n.181, 230n.182

Tithe 2, 27, 68

Torrens, Robert 25

Townsend, Rev. Horatio 27-8, 29

Tuke, James Hack 47-8

Tyrone 91, 96, 150, 230n.181

Ultramontanism 8, 182, 199, 208 see also Devotional Revolution

United States of America clergy in $43,67,74,78,79,92-8$, $118,120,163,165,171,183$, $209,210-11,234,236$

Irish in $63,67,73,127,165,187-8$, 199, 203, 214, 216 as migrant destination $3,4,28$, $37,43,46,47,66,76,77,150$, 161-2, 192, 197, 201

Vaughan, Bishop Daniel (Killaloe) 64 Victoria (Australia) 114, 115, 123, 131,132

Victoria (Canada) 127

wages

Ireland 32, 34, 44

overseas $44,46,95$

Wakefield, Edward Gibbon 26, 39, $55 n .86$

Welsh, Rev. John 69, 72

Westmeath 34, 150, 163

Wexford 28, 65, 77

Whately, Archbishop Richard (Dublin) 27, 29, 31, 36, 38, 42, 44, 108, 117, 141n.138

Whelan, Irene 155, 174n.39

Wicklow 36, 43, 122, 150, 210

Wilde, Sir William 183, 185

Woodlock, Bishop Bartholomew (Ardagh and Clonmacnoise) $103,118,120,121,125,127$, $128,129,187$

workhouse 41, 44, 46, 64, 79, 150, 151

Yorke, Rev. Peter 236 